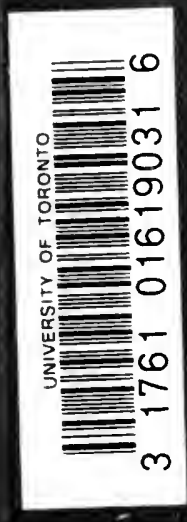


Digitized by the Internet Archive in 2007 with funding from Microsoft Corporation 






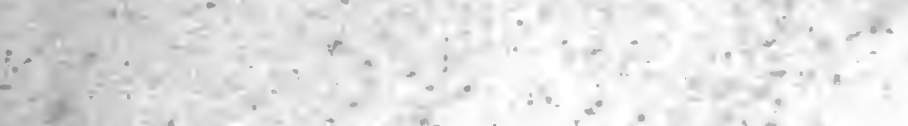



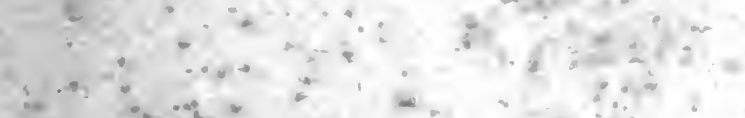

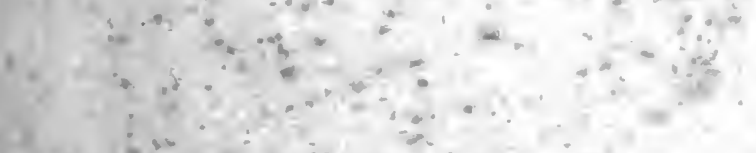

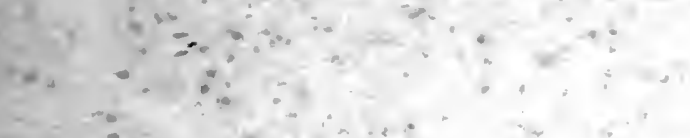





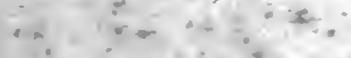

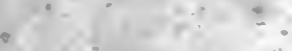

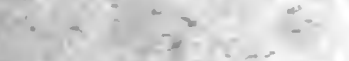

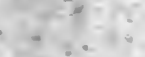

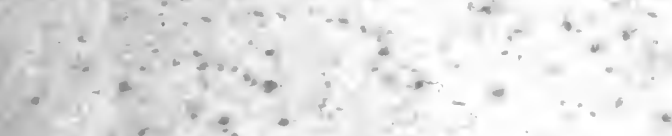

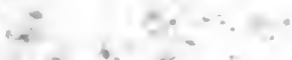

3.

$\therefore \therefore+\ldots, \cdots+\cdots$

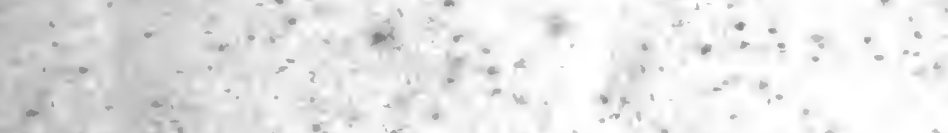

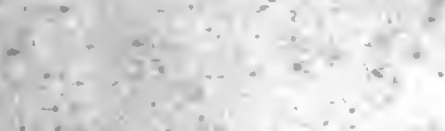

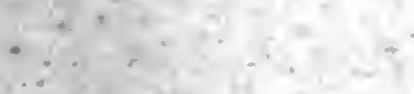

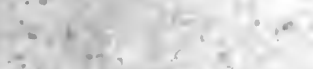

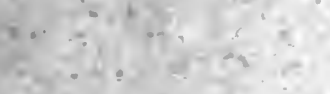

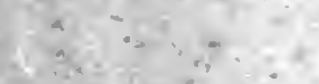

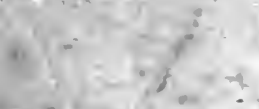

$-1, y=-7$

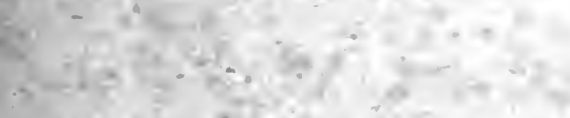

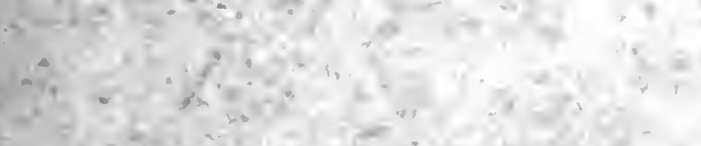





\title{
IMPERIAL GAZETTEER OF INDIA
}

\author{
PROVINCIAL SERIES
}

NORTH-WEST FRONTIER PROVINCE

SUPERINTENDENT OF GOVERNMENT PRINTING CALCUTTA

I908

Price Rs. 2-8, or 3s. 9d.] 


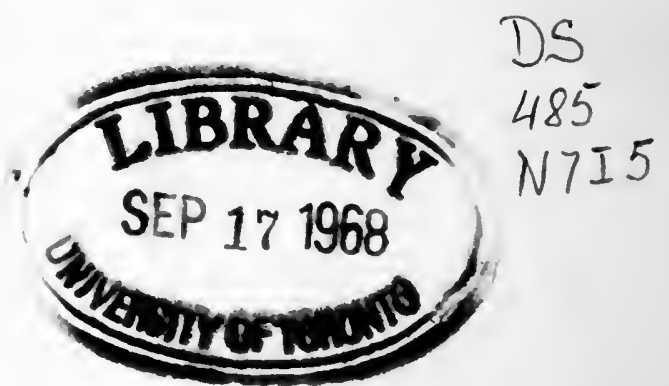




\section{PREFACE}

THE articles contained in this volume were originally drafted by Mr. H. A. Rose, I.C.S., and were afterwards examined by the District and Political Officers concerned. In preparing the Provincial article valuable assistance was received from heads of departments. Mr. E. B. Howell, I.C.S., who was in charge of the final revision, has added later statistics and much interesting information, especially in the articles on Tribal Areas. 


\section{TABLE OF CONTENTS}

North-I est Frontier Province .

Natural features and scenery . . . . . . . I

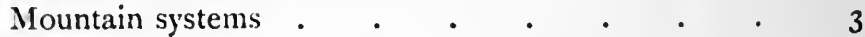

Rivers . . . . . . . . . . 4 . 4

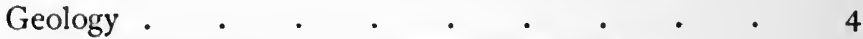

Crystalline, igneous, and metamorphic rocks . $\quad 4$

Tanãwals . $. \quad . \quad . \quad . \quad$. $\quad$. 5

Basic dikes . $\quad . \quad$. $\quad . \quad$. $\quad$. 5

The Attock slate series..$\quad$. $\quad$. 5

Mesozoic, Tertiary, and post-Tertiary rocks to the south 5

Infra-Trias (Devonian ?) $\quad . \quad$ • $\quad$. 5

Trias . . . . . . . . . 6



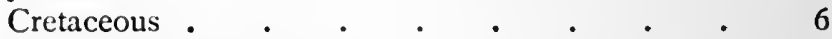

Nummulitic (eocene) . $\quad$. $\quad . \quad$. $\quad . \quad$. 7

Post-Tertiary and recent $. \quad . \quad . \quad . \quad .7$

Flora

Fauna . . . . . . . . . . 10

Climate and temperature . $\quad . \quad . \quad . \quad . \quad$. $\quad$ I r

Rainfall . . . . . . . . . . . I I

HISTORY . . . . . . . . . $12-26$

The Persians . $\quad . \quad$. $\quad . \quad$. $\quad . \quad$. $\quad$. 12

The Greeks . . . . . . . . . . $\quad$ I3

The Bactrians . . . . . . . . . . . I $_{3}$

The Kushans . $\quad . \quad$ • $\quad . \quad$. $\quad . \quad$. $\quad$ I 4

Later Kushans and White Huns . . . . $\quad$. $\quad$ r4

The Muhammadans . $\quad . \quad$. $\quad . \quad$. $\quad$. 15

The Ghorids . . . . . . . . . . 15

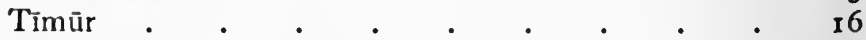

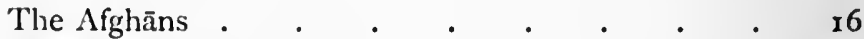

The Mughals . . . . . . . . . . $\quad . \quad 16$

Tribal rebellions $\quad . \quad . \quad . \quad . \quad . \quad . \quad . \quad . \quad$ I 7

Decay of Mughal power . . . . . . $\quad$. 18

The Sikhs . . . . . . . . . $\quad . \quad 18$

The British . $\quad . \quad$. $\quad . \quad$. $\quad . \quad$. $\quad$. 19

The Mutiny $\quad . \quad$. $\quad . \quad$. $\quad . \quad$. $\quad . \quad$. 19

Expeditions against frontier tribes . . . . 20 $1849-57$. $. \quad . \quad . \quad . \quad . \quad . \quad .20$

$1857-78 \quad . \quad . \quad . \quad . \quad . \quad . \quad . \quad 20$ 
Second Afghān War, I 878-80

1'AGF,

Expeditions, $1878-97$. .

Pathān revolt, 1897

In Tochi .

In Swāt

The Mohmands

\section{Tīrāh}

Punitive operations

Durand line .

Formation of the North-West Frontier Province

Buddhist remains

Later buildings

Population .

Census statistics

Density

$\cdot . \cdot \cdot \cdot 28$

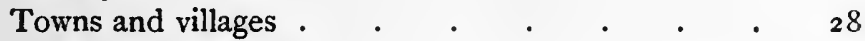

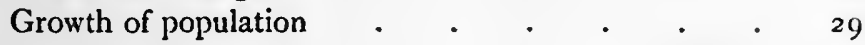

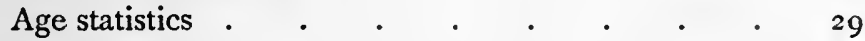

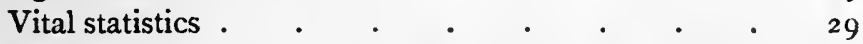

Diseases . . . . . . . . . . 30

Epidemics

Infant mortality. Sex statistics . . . . 30

Statistics of civil condition . . . . . . 30

Language

Castes and tribes

The Pathāns

Awāns, \&c. .

Religions .

Christian missions.$\quad$. $\quad . \quad$. $\quad$. $\quad . \quad$. 34

Occupations . . . . . . . . . . $\quad . \quad 34$

Food

Dress . . . . . . . . . . 35



Disposal of dead . $\quad . \quad . \quad . \quad . \quad . \quad . \quad . \quad 36$

Amusements . . . . . . . . . $\quad 3^{6}$

Names and titles . . . . . . . . . $3^{6}$

Religious titles. $. \quad . \quad . \quad . \quad . \quad . \quad .37$

Agriculture. $. \quad \cdot \quad \cdot \quad \cdot \quad \cdot \quad \cdot \quad \cdot \quad 37-45$

Soils and general agricultural conditions . . . 37

Harvests . . . . . . . . . 38

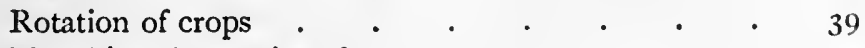

Ploughing, harvesting, \&c. $\quad . \quad$. $\quad . \quad$. $\quad . \quad 39$ 
Population supported by agriculture .

Wheat

Barley

Gram

Maize

Spiked millet .

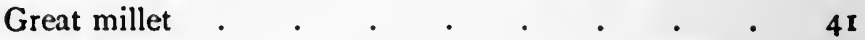

Rice

Pulses

Cotton

Oilseeds

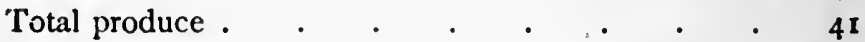

Fruit

Loans

Indebtedness

Cattle

Sheep and goats $\quad . \quad . \quad . \quad . \quad . \quad . \quad .43$

Camels . . . . . . . . . . . 433

Horses and donkeys. $\quad . \quad$. $\quad . \quad$. $\quad . \quad$. 43

Irrigation. $. \quad . \quad . \quad . \quad . \quad . \quad . \quad .43$

Canal revenue . $\quad . \quad . \quad . \quad . \quad . \quad . \quad . \quad 45$

System of water distribution . . . . . . . . . . 45

Rents, Wages, AND PRICES . $\quad . \quad$. $\quad . \quad \cdot \quad \cdot 45-48$

Rents

Wages

Prices

Material condition of the people . . . . 47

FORESTS .

Mines and Minerals

Salt .

Other minerals .

Cotton

Afrìdi waxcloth

Wool

Silk .

Embroidery

Jewellery

Iron-work

Brass- and copper-work

Pottery

Wood-work 
Commerce and Trade .

$\cdot \quad \cdot 52$

Imports from across the border $\quad . \quad$. $\quad . \quad$. 53

Exports across the border. . . . . . 54

Trade with other Provinces and States in India. $\quad 54$

Means of Communication . . . . . . $54-56$

Railways . . . . . . . . . . . 54

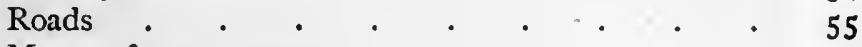

Means of conveyance $\quad . \quad . \quad . \quad . \quad . \quad . \quad 55$

Rivers . . . . . . . . . . 56

Post Office . . . . . . . . . $\quad . \quad 56$

FAMINE . . . . . . . . . . 56

Administration . . . . . . . . . . 57-59

Administrative divisions . . . . . . $\quad . \quad 58$

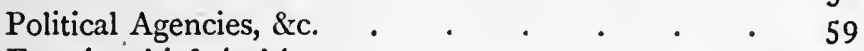

Frontier chieftainships . $\quad . \quad$. $\quad . \quad . \quad . \quad 59$

Legislation and Justice . . . . . . . 59-6I

Customary law. . $\quad . \quad$. $\quad . \quad$. $\quad . \quad$. 59

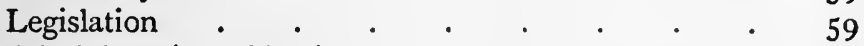

Administration of justice . . . . . . 60

Civil courts . $\quad . \quad . \quad . \quad . \quad . \quad . \quad .60$

Criminal courts . . . . . . . . 60

Revenue courts . . . . . . . . $6 \mathrm{r}$

Trans-border territories . . . . . . 6 $6 \mathrm{r}$

Registration . . . . . . . . . $6 \mathrm{r}$

Finance. . . . . . . . . . $6 \mathrm{r}$

Land Revenue . . . . . . . . . . . . 62-64

Tenures . $\quad . \quad . \quad . \quad . \quad . \quad . \quad . \quad .62$

Redistribution of land $\quad . \quad . \quad . \quad . \quad . \quad . \quad .62$

Settlement $. \quad . \quad . \quad . \quad . \quad . \quad . \quad .663$

Alienations . . . . . . . . . . 64

Miscellaneous Revenue . . . . . . . 64-67

Salt . . . . . . . . . . 64

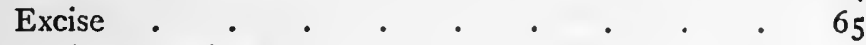

Liquors and drugs $\quad . \quad . \quad . \quad . \quad . \quad . \quad .666$

Hemp drugs . $\quad . \quad . \quad . \quad . \quad . \quad . \quad .666$

Method of vend . . . . . . . . 66

Excise revenue . . . . . . . . 66

Stamps and income tax . . . . . . 67

Local AND Municipal . . . . . . . 67-68

Village communities. $. \quad . \quad . \quad . \quad . \quad .67$

Municipal administration . . . . . . 67

District boards . . . . . . . . 68



ARMY • . . . . . . . . . . 69 
Pol.ice

Proportion of police to area and population

Rural police

Municipal, cantonment, ferry, and railway police

Cognizable crime

Border military police $. \quad . \quad . \quad . \quad . \quad .71$

Miritia ANd Levy CoRps

Militia

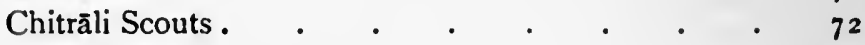

Levy Corps

Education

Present organization.

Collegiate education. $\quad . \quad$. $\quad . \quad$. $\quad . \quad$. 74

Secondary education $. \quad . \quad . \quad . \quad . \quad . \quad 74$

Primary education (male). . . . . . 75

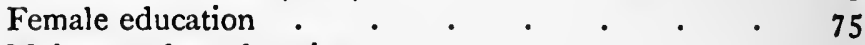

Muhammadan education . $\quad . \quad$. $\quad . \quad$. $\quad 75$

Statistics . $\quad . \quad . \quad . \quad . \quad . \quad . \quad . \quad .75$

Medical . . . . . . . . . . $76-77$

Hospitals and dispensaries . . . . . . $\quad$. 76

Lunatic asylums $\quad . \quad . \quad . \quad . \quad . \quad . \quad$. 76

SURVEYS

Vaccination . . . . . . . . . . 76

BIBLIOGRAPHY . $\cdot 0$

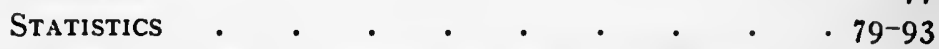

Table I. General Genealogy of the Pathān Tribes . 79

" II. Expeditions undertaken against Frontier Tribes since the Annexation of the Punjab 80

III. Temperature $\quad . \quad$. $\quad . \quad$. 83

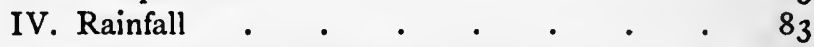

V. Distribution of Population, I90I . . . 84

VI. Statistics of Agriculture $\quad$. $\quad$. 85

"VII. Trade with other Provinces (including the Punjab) and States in India . . . 86

VIIA. Trade with Countries outside India $\quad$. $\quad 87$

VIII. Statistics of Criminal Justice $\quad$ - . $\quad$. 87

IX. Statistics of Civil Justice . . . $\quad$. 87

$\mathrm{X}$. Revenue and Expenditure . $\quad$. $\quad$. $\quad 88$

XI. Income and Expenditure of Municipalities 89

XII. Income and Expenditure of District Boards 90

XIII. Police Statistics . . . . . . . 91

XIV. Education Finance $\quad . \quad$. $\quad$. $\quad$ : $\quad$. 92

XIVA. Colleges, Schools, and Scholars . . . 92

" XV. Medical Statistics . • . . . . . 93 
Mountains

Himalayas, The $\quad . \quad$. $\quad . \quad$. . . . 94-107

Name . . . . . . . . . . . . $\quad$. 94

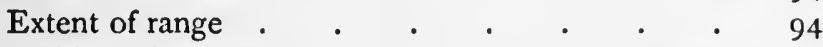

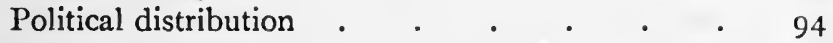

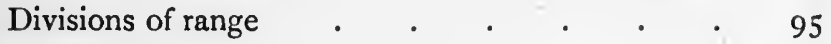

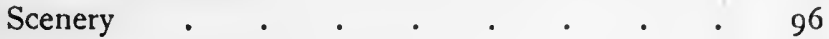

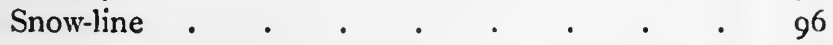

Rivers . . . . . . . . . $\quad$. 97

Highest peaks . . . . . . . 97

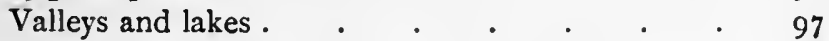

Geology . . . . . . . . . 98

Age and origin of the range . . . . $\quad$. 98

The Siwālik series . $\quad . \quad$. $\quad . \quad$. $\quad .99$

Unfossiliferous rocks of Outer Himālayas . . 100

The crystalline axis . . . . . . r roo

Fossiliferous rocks of the Tibetan zone . . Ior

Economic minerals . . . . . . 102

Botany. . . . . . . . . . 102

Fauna . . . . . . . . . . . 103

People. . . . . . . . . . . 104

Agriculture . $\quad . \quad . \quad . \quad . \quad . \quad . \quad . \quad 105$

Forests . . . . . . . . 106

Means of communication . . . . . 106

Bibliography : . . . . . . 107

Black MountalN . . . . . . . 107

MAHĀBAN •. . . . . . . . 108

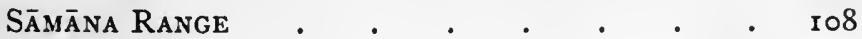

RIVERS

109-1 20

INDUS . . . . . . . . rog-Ir6

Course in Tibet and Kashmir $\quad$. $\quad . \quad$. 109

In the Punjab and the North-West Frontier Province . . . . . . . IIO



The Indus delta . . . . . . . II2

Changes in the river course . . . . . II 3

Inundations and irrigation . . . . . . $\mathrm{Y}_{4}$

Principal canals . . . . . . . II4

Navigation . . . . . . . . . 115

Fish . . . . . . . . 116

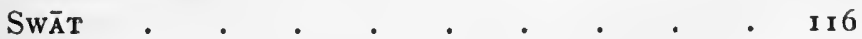

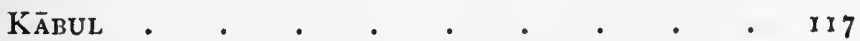

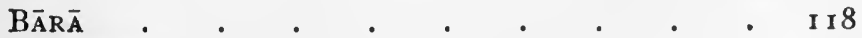

KURRAM . • • . . 
TochI

Gumal

Canals .

SWĀT RIVER

KābUL RIVER.

I 2 I

Historic Areas

1 22-I 25

AMB

122

Derajāt .

122

GANDHĀRA

124

PAKHLI .

UND

124

Hazāra District

125

$126-143$

Boundaries, configuration, and hill and river systems . $\quad 126$

Geology

Botany

127

Fauna

Climate and temperature

Rainfall

History

Archaeology

The people

128

Castes and occupations

Christian missions

130

General agricultural conditions .

I3I

Chief agricultural statistics and principal crops . . $\quad \mathbf{I}_{3} \mathbf{I}$

Improvements in agricultural practice . . . $\mathbf{I 3 2}^{2}$

Cattle, ponies, and sheep . . . . . . $\quad \mathbf{1}^{1} 3^{2}$

Irrigation

Forests

Mines and minerals .

Arts and manufactures

132

Commerce and trade

I33

Means of communication .

134

134

Famine

District subdivisions and staff

Civil and criminal justice .

Land revenue administration ..$\quad \cdot \quad \cdot \quad \cdot 135$

Local and municipal . . . . . . . 136

Police and jails . . . . . . . . $\quad$. 136

Education . . . . . . . . . 136

Hospitals and dispensaries . . . . . $\quad$ I 37

Vaccination . . . . . . . . $\quad$ r 37

Bibliography . . . . . . . . . 137

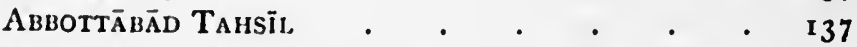




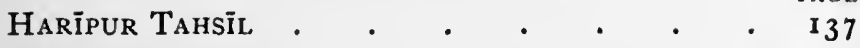

Mànsehra Tahsīl . $\quad . \quad . \quad . \quad . \quad . \quad . \quad{ }^{1} 37$

TANĀWAL.$\quad \cdot \quad \cdot \quad \cdot \quad \cdot \quad \cdot \quad \cdot \quad \cdot 138$

ABBottĀBĀD Town.

AGROR .

BAFFA • . . . . . . . . .

BARA GaLI . . . . . . . . 141

Chângla Gali . . . . . . . . 141

Dungā Gali . . . . . . . . . I4I

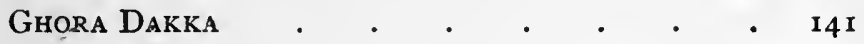

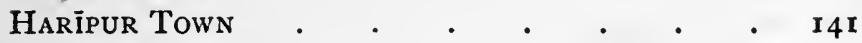

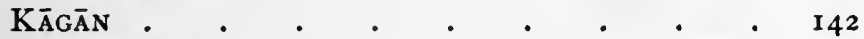

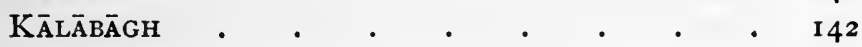

KhaIRA GaLI . . . . . . . . . $\mathrm{I}_{22}$

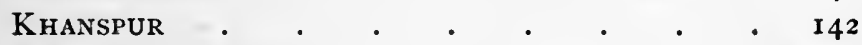

MĀNSEHRA TOWN $. \quad . \quad . \quad . \quad . \quad . \quad .142$

Nathia Gali . . . . . . . . $\quad$. 143

NAWĀSHAHR .

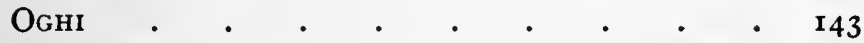

THANDIĀNI .

Peshātar District . . . . . . . $\mathrm{I}_{43}-\mathrm{I} 67$

Boundaries, configuration, and hill and river systems. I43

Geology • • . . . . . . . . . 145

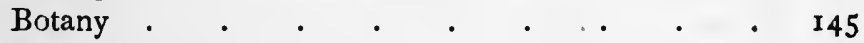

Fauna . . . . . . . . . . . . $\quad . \quad 146$

Climate and temperature . $\quad . \quad . \quad . \quad . \quad$ I46

Rainfall . . . . . . . . . . . 146

History and archaeology . . . . . . 146

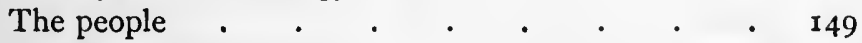

Castes and occupations . . . . . . . 150

Christian missions . $\quad . \quad$. $\quad . \quad$. $\quad . \quad$. $\mathrm{r}_{5} \mathrm{r}$

General agricultural conditions . . . . . I5I

Chief agricultural statistics and principal crops . $\quad{ }^{1} 5^{1}$

Improvements in agricultural practice . . $\quad{ }_{152}$

Cattle, ponies, and sheep . . . . . . $\quad$ I 152

Irrigation.$\quad \cdot \quad \cdot \quad \cdot \quad \cdot \quad \cdot \quad \cdot{ }^{\circ} 5^{2}$

Forests . . . . . . . . . ${ }_{152}$

Mines and minerals . $\quad . \quad$. $\quad . \quad$. . . 153

Arts and manufactures $. \quad . \quad . \quad . \quad . \quad . \quad 153$

Commerce and trade . $\quad . \quad$. $\quad . \quad$. $\quad$. 153

Communications . $\quad . \quad$. $\quad . \quad$. $\quad . \quad$. 154

District subdivisions and staff . . . . . $\quad$ 154

Civil and criminal justice . $\quad . \quad$. $\quad . \quad$ I $\quad$ I54

Land revenue administration . . . . . 155 
Local and municipal

Police and jails $. \quad . \quad . \quad . \quad . \quad . \quad$. 156

Education . . . . . . . . $\quad$. 157

Hospitals and dispensaries . . . . . $\quad$. 157

Vaccination . . . . . . . . 157

Bibliography . . . . . . . . 157

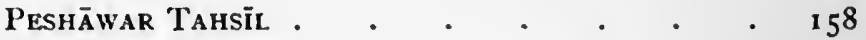

Chấrsadda Tahsíl. . . . . . . ${ }^{1} 5^{8}$

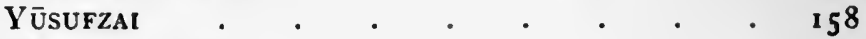

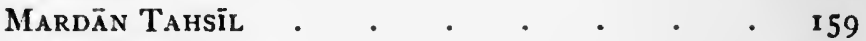

SWĀBI TAHSīl. . . . . . . . . I60

Naushahra Tahsīl $\quad . \quad . \quad . \quad . \quad . \quad . \quad$. 160

ABĀZaI . . . . . . . . . 160

Chärsadda Town . . . . . . .

Cherát . . . . . . . . . $16 \mathrm{I}$

HAShTNAGar . . . . . . . . . . 162

MACKESON, FORT . . . . . . . . 162

MARDĀN TOWN $\quad . \quad . \quad . \quad . \quad . \quad . \quad . \quad . \quad 163$

MICHNi • .

Naushahra Town . . . . . . . . . . 163

Peshäwar City . . . . . . . . .

PRĀNG . . . . . . . . . . .

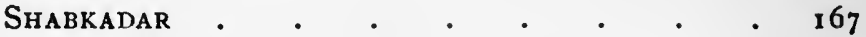

TANGI . . . . . . . . . . . $\quad .167$

KOHĀT District . . . . . . . . I67-182

Boundaries, configuration, and hill and river systems . $\quad 167$

Geology . • • . . . . . . 168

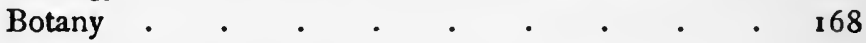

Fauna $\cdot \quad \cdot \quad \cdot \quad \cdot \quad \cdot \quad \cdot \quad \cdot \quad \cdot \quad \cdot \quad 169$

Climate and temperature . $\quad . \quad . \quad . \quad . \quad . \quad 169$

History . . . . . . . . . . . 169

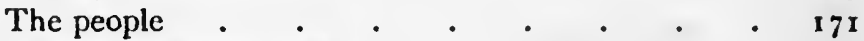

Castes and occupations . . . . . . . $\quad . \quad 172$

General agricultural conditions . . . . . 172

Chief agricultural statistics and principal crops . . 173

Improvements in agricultural practice . . . $\quad$ I 73

Cattle, ponies, and sheep . . . . . . . 174

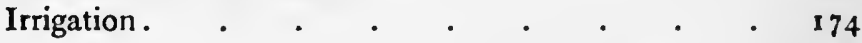

Forests . . . . . . . . . . 174

Mines and minerals . $\quad . \quad . \quad . \quad . \quad . \quad .174$

Arts and manufactures . . . . . . 175

Commerce and trade $\quad . \quad$. $\quad . \quad$. $\quad . \quad$. 175

Communications . . . . . . . . 175

Famine . . . . . . , . . 175 
District subdivisions and staff .

Civil and criminal justice . . . . . . 176

Land revenue administration . . . . . 176

Local and municipal . $\quad . \quad$. $\quad . \quad$. 177

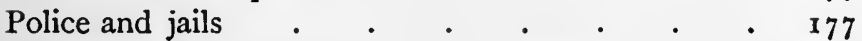

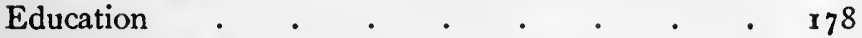

Hospitals and dispensaries . . . . . 178

Vaccination . . . . . . . . . $\quad{ }_{178}$

Bibliography . . . . . . . . $\quad$. 178

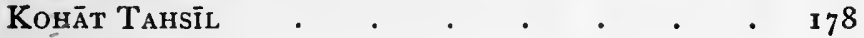

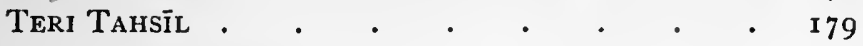

Thal Subdivision •

Hangu Tahsīl

HANGU Village . . . . . . . . 180

KOHĀT TOWN . . . . . . . . . 180

Kohāt Salt Quarries . . . . . . 180

LOCKHART, FORT • . $\quad . \quad+\quad \cdot \quad \cdot \quad \cdot 18 \mathbf{I}$

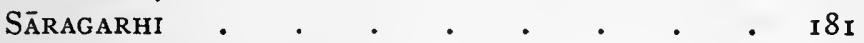

Thal Village . . . . . . . $\mathbf{I} 8 \mathbf{I}$

Bannu District . . . . . . . $182-195$

Boundaries, configuration, and hill and river systems . $\quad$ I 82

Geology . . . . . . . . . 183

Botany . . . . . . . . . . $\quad .183$

Fauna . . . . . . . . . . $\quad .183$

Climate and temperature . $\quad . \quad . \quad . \quad . \quad . \quad 183$

Rainfall . . . . . . $\quad . \quad$. $\quad . \quad$. 184

History . . . . . . . . . 184

Archaeology . $\quad . \quad . \quad . \quad . \quad . \quad . \quad . \quad 185$

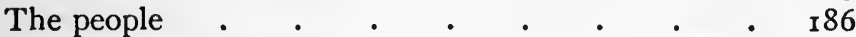

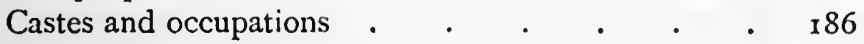

Christian missions.$\quad$. $\quad . \quad$. $\quad . \quad$. 187

General agricultural conditions . . . $\quad 187$

Chief agricultural statistics and principal crops . $\quad$. $\quad 188$

Improvements in agricultural practice . . $\quad$ I 188

Cattle, ponies, and sheep - . $\quad . \quad$. $\quad . \quad$. 188

Irrigation $\quad \cdot \quad \cdot \quad \cdot \quad \cdot \quad \cdot \quad \cdot \quad \cdot \quad \cdot \quad 189$

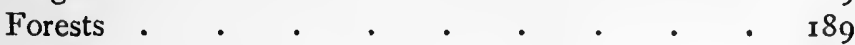

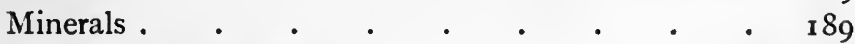

Arts and manufactures $\quad . \quad$. $\quad . \quad . \quad . \quad$. $\quad 189$

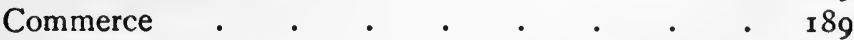

Communications $\quad . \quad$. $\quad . \quad$. $\quad . \quad$. $\quad$. 189

Famine . . . . . . . . . . 190

District subdivisions and staff . . . . .

Civil and criminal justice. . . . . . 190 
Land revenue administration

$\cdot \quad \cdot \quad \cdot \quad \cdot \quad 19$

Local and municipal . $. \quad . \quad$. . . 192

Police and jails.$\quad$. $\quad$. $\quad$. $\quad$. 192

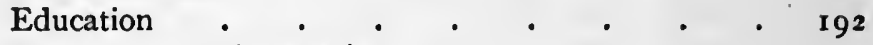

Hospitals and dispensaries $\quad . \quad$. $\quad . \quad$. 193

Vaccination . $\quad . \quad \cdot \quad \cdot \quad \cdot \quad \cdot \quad \cdot \quad \cdot 193$

Bibliography . . . . . . . . 193

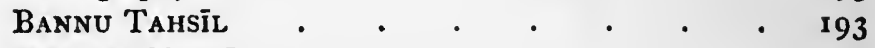

Marwat Tahsīl $. \quad . \quad . \quad . \quad . \quad . \quad$. 193

Bannu Town (or Edwardesābād) • . . . $\quad$. 193

LAKK1 • • • • • • • • • 194

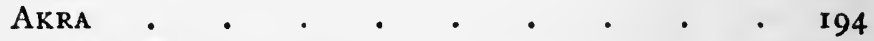

Dera Ismail Khān District . . . . 195-209

Boundaries, configuration, and hill and river systems. $\quad 195$

Geology . . . . . . . . . 196

Botany . . . . . . . $\quad$. $\quad$. $\quad$. 197

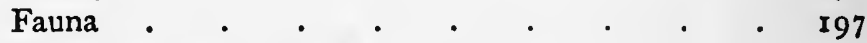

Climate and temperature . $\quad . \quad$. $\quad . \quad$. $\quad$. 197

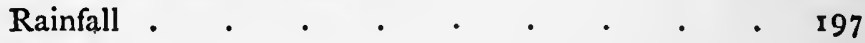

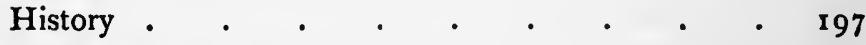

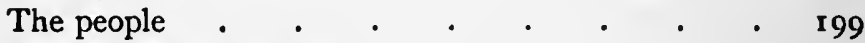

Castes and occupations . $\quad . \quad$. $\quad . \quad$. $\quad . \quad$ 199

Christian missions . $. \quad . \quad . \quad . \quad . \quad 200$

General agricultural conditions. . . . . 200

Chief agricultural statistics and principal crops . . 200

Improvements in agricultural practice . . . 200

Cattle, ponies, and sheep. . . . . . $20 \mathrm{I}$

Irrigation. . . . . . . . . $20 \mathrm{I}$

Forests . . . . . . . . . . $20 \mathrm{I}$

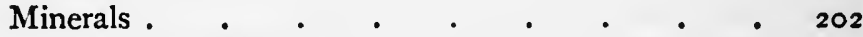

Arts and manufactures . $\quad . \quad$. . . 202

Commerce and trade . . . . . . . 202

Communications . . . . . . . 202

Famine . . . . . . . . . . . 202

District subdivisions and staff . . . . . 203

Civil and criminal justice . $\quad . \quad$. . . . 203

Land revenue administration . . . . . 203

Local and municipal $\quad . \quad$. $\quad . \quad$. $\quad . \quad 204$

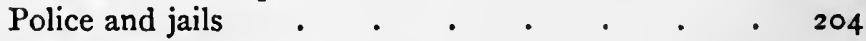

Education . $\quad . \quad . \quad . \quad . \quad . \quad . \quad .204$

Hospitals and dispensaries $\quad . \quad$. $\quad . \quad$. 204

Vaccination . . . . . . . . 205

Bibliography . . . . . . . . 205

Dera Ismail Khān Tahsīl . • • • • 205 
KULĀCH TAHSiL

• • • • • • 205

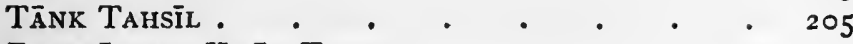

DeRA Ismail KhĀN TOWN $. \quad . \quad . \quad . \quad . \quad 207$

KĀFIRKOT .

KULĀCHI TOWN . . . . . . . 208

SHEIKH BudīN.$\quad$. $\quad . \quad$. . . . 208

TĀNK TOWN .

Dīr, Swät, ANd ChitrāL , . . . . 210-223

Chitrāl State . . . . . . 2IO-2I5

Boundaries, configuration, and hill and river systems. 2 10

History

The people .

General agricultural conditions . . . . 214

Manufactures and trade . . . . . 2 I4

Administration . . . . . . . 2I4

Justice • • • • • • • • . 214

Revenue . . . . . . . . . 214

Chitrāl Town . . . . . . . . 214

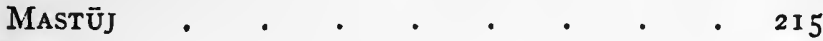

Dír

Swāt State.$\quad \cdot \quad \cdot \quad \cdot \quad \cdot \quad \cdot \quad \cdot \quad \cdot 216$

MALAKAND . . . . . . . . $22 \mathrm{I}$

Chakdarra - . . . . . . . 221

Bājaur .. . . . . . . . . . . . 222

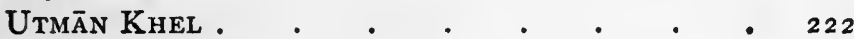

BUNER

AMBELA.

$223^{-225}$

- 224

$225-227$

$227-236$

Situation. $. \quad . \quad . \quad . \quad . \quad . \quad . \quad$. 227

Description . . . . . . . . 227

History . . . . . . . . . 228

British expeditions • . . . . . . . 229

First Afghān War. $\quad . \quad$. $\quad . \quad$. $\quad . \quad 229$

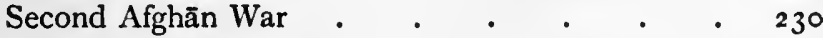

Khyber Political Agency . . . . . . $23 \mathrm{I}$

The Afrīdis . . . . . . . . $23 \mathrm{I}$

British control . $\quad . \quad$. $\quad . \quad$. . 232

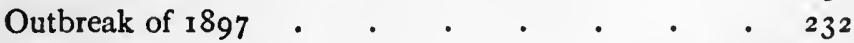

AFRIDIS • • • . $\quad \cdot \quad \cdot \quad \cdot \quad \cdot \quad \cdot \quad \cdot 232$

JAMRŨd • • • • • • • • • •

LANDi Kotal . . . . . . . . $\quad$. 233

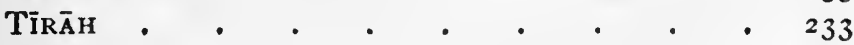

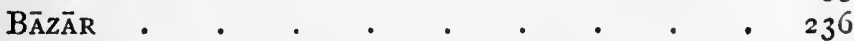

OrakzaI . . . . . . . . . 236 
Kurram Agency

Boundaries, configuration, and hill and river systems . $\quad 236$

History

The people

238

- 240

Means of communication . . . . . . 241

Administrative divisions and staff . . . . 24I

Civil and criminal justice. . . . . . $24 \mathrm{I}$

Land revenue administration . . . . . 242

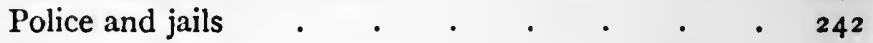

Education . $. \quad . \quad . \quad . \quad . \quad . \quad .243$

Hospitals and dispensaries $\quad . \quad$. $\quad . \quad$. $\quad . \quad 243$

Vaccination $. \quad . \quad . \quad . \quad . \quad . \quad . \quad \cdot 243$

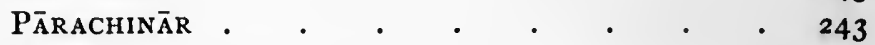

SADDA.$\quad \cdot \quad \cdot \quad \cdot \quad \cdot \quad \cdot \quad \cdot \quad \cdot \quad \cdot 243$

Wazíristān, Northern. . . . . . . 243-248

BOYA . . . . . . . . . . 245

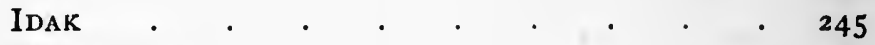

Miram ShāH .

MAIZAR . . $\quad . \quad \cdot \quad \cdot \quad \cdot \quad \cdot \quad \cdot \quad \cdot 245$

DAUR . $. \quad . \quad . \quad . \quad . \quad \cdot \quad \cdot \quad \cdot 246$

WAZiRISTĀN, SOUTHERN . . . . . . 248-257

Boundaries, configuration, and hill and river systems . $\quad 248$



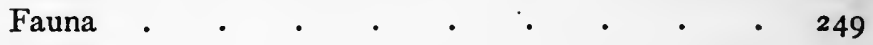

Climate . . . . . . . . . 249

History . . . . . . . . . 250

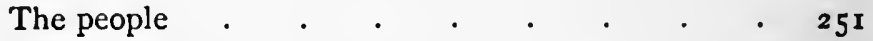

Tribal customs . $\quad . \quad . \quad . \quad . \quad . \quad$. 252

Agriculture . $\quad . \quad+\quad . \quad$. $\quad . \quad$. 252

Mines and minerals . $\quad . \quad$. $\quad . \quad$. $\quad 252$

Arts and manufactures . . . . . 252

Commerce and trade . . . . . . . 253

WĀNĀ $\quad \cdot \quad \cdot \quad \cdot \quad \cdot \quad \cdot \quad \cdot \quad \cdot \quad \cdot 253$

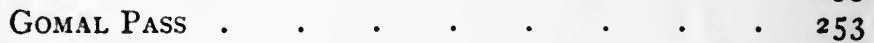

MahsūDS $\quad \cdot \quad \cdot \quad \cdot \quad \cdot \quad \cdot \quad \cdot \quad \cdot \quad \cdot 253$

BhittanNi . . . . . . . . 255

JANDOLA . . . . . . . . $\cdot 256$

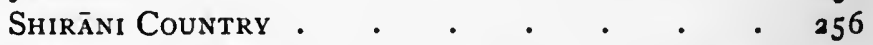

TAkHT-1-SUlaimān . $\quad . \quad \cdot \quad \cdot \quad \cdot \quad \cdot \quad \cdot 257$

INDEX . . . . . . . . . 259-280

MAP . . . . . . . . . . . at end 


\section{PROVINCIAL GAZETTEERS OF INDIA}

\section{NORTH-WEST FRONTIER PROVINCE}

North-West Frontier Province.-The North-West Fron- Position tier Province lies between $31^{\circ} 4^{\prime}$ and $36^{\circ} 57^{\prime} \mathrm{N}$. and $69^{\circ} 16^{\prime}$ and bounand $74^{\circ} 7^{\prime} \mathrm{E}$. Its extreme length between these parallels is 408 miles, and its extreme breadth between these meridians 279 miles. The approximate area is 38,665 square miles, of which only 13,193 are British territory, the remainder being held by the tribes under the political control of the Agent to the Governor-General. As its name denotes, the Province is situated on the north-west frontier of the Indian Empire. On the north it is shut off from the Pãmirs by the mountains of the Hindu Kush. To the south it is bounded by Baluchistān and the Dera Ghāzi Khān District of the Punjab; on the east by the territories of the Mahārājā of Kashmīr and by the Punjab ; on the west by Afghānistān.

The territory falls into three main geographical divisions: Natural the Cis-Indus District of Hazāra; the comparatively narrow features strip between the Indus and the hills constituting the Districts scenery. of Peshāwar, Kohāt, Bannu, and Dera Ismail Khān; and the rugged mountainous regions on the north and west between those Districts and the borders of Afghānistān.

Hazãra District forms a wedge extending north-eastwards far into the Outer Himālayan range, and tapering to a narrow point at the head of the Kāgann valley. The mountain chains which enclose the Kāgān defile sweep southwards into the broader portion of the District, throwing off well-wooded spurs which break up the country into numerous isolated glens. Towards the base of the wedge, on the confines of the Attock District of the Punjab, the hills open out and fertile plains take the place of the terraced hill-sides and forests of the northern uplands. The tract between the Indus and the hills ww.r.P. 
comprises four minor natural divisions, each of which forms a separate District. The most northern is the Peshãwar valley, a lacustrine basin encircled by hills. To the south of Peshawar lies Kohāt, a rugged table-land broken by low ranges of hills and separated from Peshãwar by the Jowāki range. South of Kohāt again is Bannu, in the broad basin of the Kurram river and completely surrounded by low ranges. The District of Dera Ismail Khān stretches south of Bannu, a vast expanse of barren plain enclosed between the Sulaimann range on the west and the Indus on the east, and tapering to a blunt point at its southern extremity.

The regions between these Districts and the Afghān frontier are equally varied, but wilder and more rugged in character. The hills are loftier, often rising into ranges of great height, and the intervening valleys are narrower and more inaccessible. On the north, vast territories between the Hindu Kush and the border of Peshāwar District form the Political Agency of Dìr, Swāt, and Chitrāl. Of these territories, Chitrāl, the most northern, is a region of deep valleys and lofty ranges, for the most part bare and treeless. Farther south lie the thickly wooded hills of Dīr and Bājaur, and the fertile valleys of the Panjkora and Swāt rivers. South-west of this Agency are the Mohmand hills, a rough and rocky tract with little cultivation. Farther south comes the narrow gorge of the Khyber Pass, leading westwards from Jamrūd on the Peshāwar border into Afghānistān. South of the pass lies Tîrāh, the maze of mountains and valleys held by the Afridi and Orakzai tribes, and bordered on the western extremity of its northern border by the Safed Koh. Farther west this range still forms the border of the Province, and flanks the Kurram valley in the Political A gency of that name. This fertile valley stretches south-eastwards from the great peak of Sikarām, in which the Safed Koh culminates, and the Peiwar Kotal pass to the western extremity of the Mīrānzai valley in Kohāt. South of Kurram lies Wazīistān, a confused mass of hills, intersected on the north by the Tochi valley and on the south by the gorges that descend to the Wanna plain. The hills are for the most part barren and treeless, but on some of the higher ranges, such as Shawāl and Pïr Ghal, fine forests are found. The valleys also broaden out into plains, and form fertile and well-irrigated dales. Such are Daur, as the lowlands of the Tochi valley are called, and Kaithu in Northern Waziristān, and the Wāna plain and the valley below Kāniguram in the south. The Wazir hills are divided into two Political Agencies : 
Northern Waziristān, with its head-quarters in the Tochi valley; and Southern Wazīistān, with its head-quarters at Wāna. In the latter Agency the Wazir hills merge into the Sulaimann range, the highest point of which is the far-famed Takht-iSulaimān in the lower Shirāni country, a political dependency of Dera Ismail Khān District. The precipitous Takht presents the grandest scenery on the frontier, and forms an impassable barrier between the North-West Frontier Province and Baluchistān.

Hazāra District lies on the east bank of the Indus among Mountain the confuséd mass of mountains formed by the meeting of the systems.

Outer and Mid-Himālayan ranges. From this mass the two mountain walls, which enclose Kāgān, run in unbroken lines to where they meet at the Babusar pass ( $13,5^{89}$ feet). West of the Indus the mighty range of the Hindu Koh, usually called the Hindu Kush, or Indian Caucasus, runs almost due east and west along the north-eastern and northern frontiers of the Province, and at its north-eastern corner meets a continuation of the Outer Himālayan chain which crosses the Indus above the Kāgann valley. From this chain minor ranges descend in a north-westerly direction, traversing Bājaur and Swāt, until they meet the curved range of hills which connects the Mid-Himālaya with the Safed Koh and encircles the Peshāwar valley on the north.

From the Dorāh pass on the Hindu Kush a long broken line of mountains runs almost due south, dividing the Province from Kāfiristān, and farther south from other parts of Afghānistān. It is pierced at Arnawai by the Chitrāl river, which runs thence, under the name of the Kunar, parallel with it in Afghān territory. Thus the Hindu Kush and the two ranges which run southward from it enclose the Dìr, Swāt, and Chitrāl Agency, the whole intervening space being filled by the minor ranges which descend from them. The western line is again pierced after its junction with the Kunar by the Kābul river, south of which it merges in the Khyber hills, which form the eastern extremity of the Safed Koh.

The Safed Koh also runs almost due east and west, forming the watershed between the Kābul and Kurram rivers. Eastwards minor ranges descend from its southern slopes to the Indus. The Sulaimān range runs up the western border of the Province to meet the Safed Koh, and also throws out a series of parallel spurs to the east. These traverse the whole of Kohāt District. The Sheikh Budin range, the southern extremity of the Salt Range, forms the boundary between 
Bannu and Dera Ismail Khān, and merges eventually in the Sulaimān range.

Rivers. With the exception of the Kunhār river in Hazāra which flows down the Kãgann valley into the Jhelum, the whole territory drains into the Indus. That river divides the Province from Chilās for some miles, and then enters it north of the Black Mountain. Farther south it separates Hazana from the Gadūn territory and Peshāwar, and thence forms the eastern boundary of the Province to its southern extremity, only the Isa Khel tahsil of the Miānwāli District of the Punjab lying on its western bank. Its whole course is to the south with a westerly trend, and it forms the great natural waterway of the Province. Into it flow the mountain streams of Hazāra, the Unar, Siran, Dor, and Harroh, on the eastern bank; but these are insignificant compared with its western tributaries, of which the chief are the Landai and Kurram. The former joins it at Attock and the latter below Isa Khel.

The Landai, by which name the Kābul and Swāt rivers are called below their junction, drains Kohistān, Swāt, Dīr, Chitrāl, Tìrāh, and Peshāwar District ; but these vast territories have but a small rainfall, and, as much of the water is used for irrigation, it is nowhere a great river. Its principal tributaries are the Chitrāl, which rises in the Hindu Kush; the Swāt, which rises in the hills northeast of Buner, and after receiving the waters of the Panjkora joins the Kābul river at Nisatta in Peshāwar District; and the Bāra, which drains Tìrāh and falls into the Kābul east of Peshāwar city.

The Kurram, rising in Afghān territory on the southern slopes of the Safed Koh, passes through the Kurram valley and the lower Wazir hills into Bannu District. Three miles below Lakki it is joined by the Tochi or Gambila, which drains Northern Wazĩristān.

Geology. The geology of the North-West Frontier Province exhibits Crystal- considerable diversity. The northern portion of Hazāra and neous, and metamorphic rocks. the hills on the north-north-east border of Peshāwar are built up of crystalline, igneous, and metamorphic rocks, comprising chiefly a massive micaceous gneissose granite (sometimes containing schorl and garnets), as bands or sills among thinbedded mica-schists and phyllites, much entangled with each other, and laid out in parallel flexure waves one behind the other. The axis of the folding of this zone is about north-east to south-west. In Hazāra a probably younger set of less metamorphosed sedimentary strata borders this zone on the south, consisting of a group of arenaceous and calcareous 
rocks known as the Tanãwals, which are infra-Trias in part. Tanāwals. It seems probable that the granite is older than the Trias and possibly than the infra-Trias. All these formations are somewhat sparsely invaded by a plexus of basic dike rocks (dolerites) Basic dikes. of still later age.

The middle portion of Hazăra is mainly composed of a very The Attock great, highly inclined, and irregularly cleaved slate series, sometimes graphitic, and very occasionally calcareous, in thin bands. It is probably very ancient (certainly older than the infraTrias), from which it is separated by a striking unconformity. No fossils áre known in it, and its base has never been recognized. The series outcrops in a westerly direction to Attock, where it is well exposed in the river section; and from there it continues to form the north half of the Cherāt hills, and parts at least of the Peshāwar valley near Naushahra. The slates and crystalline limestone (marble) near Attock and Naushahra are worked with some success for building and ornamental purposes. The prevailing strike direction of the slates is east-north-east to west-south-west. The slate zone is bounded on the south by a sinuous line of faulting with overthrust, from near the axis of the Cherāt hills to the Jhelum near its junction with the Kunhär river.

South and south-east of the great fault line (as well as in the Mesozoic, form of outliers in parts of the slate zone) comes a great set of Tertiary, younger formations, stretching in gentle undulations right Tertiary through the rest of Hazāra and Peshāwar, and the whole of rocks to Kohāt, Bannu, and Dera Ismail Khān. These younger formations are mainly higher Mesozoic, Tertiary, and post-Tertiary, but they also include limited outcrops and sub-zones of infra. Trias (Devonian?), Permian, and Trias. With these younger formations begin much irregularity and sinuous winding of the strike, which coincides with the direction of the bare rock ridges, and also with what may most aptly be called the curling crests of the rock waves and undulations. These, by means of devious S-shaped curves, settle down to a north and south strike in Dera Ismail Khān District at the foot of the Sulaimān range. The curved direction of the crests of the folds expresses the buckling caused by the meeting along this portion of the earth's surface of the Himalāyan, Hindu Kush, and other more western systems of crust movement, setting in from three sides against the old and rigid gneissic rocks of Peninsular India.

The so-called infra-Trias of Hazăra, which consists of a basal Infraconglomerate followed by purple sandstones, shales, and Trias 2,000 feet of dolomitic limestone, quite unfossiliferous, and nian?). 
coming beneath the Trias, has only a restricted occurrence near Abbottabād at the base of the outliers of younger rocks. Its age may be Devonian ${ }^{1}$, and it is not known elsewhere. Carboniferous strata are not certainly known in this Province. The Permo-Carboniferous formation exposed in strips along the axes of folds in the Sheikh Budin and Khisor ranges ${ }^{2}$ consists of a glacial boulder-bed with striated and faceted blocks at the base, followed by 500 feet of magnesian and white limestone with sandstones and earthy beds, containing Productus Spirifer, Bellerophon, corals, \&c. In Hazāra the Permo-Carboniferous may be represented by a felsite and hematitic breccia, found unconformably overlying the infra-Trias (Devonian?).

Trias. The Sheikh Budin and Khisor ranges also expose a continuous section, without any physical break, up through the Trias, containing Ceratites, and corresponding with the Trias of the Salt Range of the Punjab. In Hazara the Trias, represented by a massive dark-grey limestone containing Megalodon and Dicerocardium, and resembling that of Kashmir, marks the beginning of a generally continuous zoological sequence upwards through the Jurassics, Cretaceous, and Nummulitics.

Jurassics. The Sheikh Budin and Khisor Jurassics follow the Trias, and consist of thin-bedded, light buff-coloured limestones, sandstones, and clays, which have been supposed to be connected, palacontologically, with those of Cutch. Elsewhere, in the Tochi valley and Peshāwar and the Sulaimān range, they probably occur, but have not been worked out. In Hazāra they have in part a Himālayan facies and embrace black, slightly micaceous Spiti shales (30-100 feet), with ferruginous concretions, containing an abundance of typical upper Jurassic forms, e.g. Oppelia acucincta, Perisphinctes frequens, Belemnites geradi, Inoceramus, Cuculaea, and Pecten.

Creta- The Cretaceous rocks of the southern Districts ${ }^{3}$ follow ceous. above the doubtful Jurassics, and are represented by the belemnite bed, probably of neocomian age. In Hazāra roo feet of Giumal sandstone, exactly resembling its Himālayan namesake, and coming above the Spiti shales in all sections, is also of the same age; and above it appears a very thin band of orange-coloured limestone, crowded with characteristic fossils of the middle Cretaceous (cenomanian) and equivalent to the

' Lieutenant-Gencral McMahon, Geological Magasine, vol. ix, pp. 3-8 and 49-58, I902; also vol. $x$, p. 52, 1903 .

2 A. B. Wynne, Memoirs, Geological Survey of India, vol. xvii, article 2.

3 T. D. La Touche, Records, Geological Survey of India, vol. xxvi, pt. iii; and F. H. Smith, Records, Geological Survey of India, vol. xxviii, pt. iii. 
Utatūr group of Southern India, e.g. Acanthoceras mantelli, A. navicularis, $A$. rotomagensis, Schlaenbachia inflata, together with Anisoceras, Anclyloceras, Baculites, Terebratula, Echinoconus, and Micraster. Similar rocks are known from the Samāna country.

The grey, concretionary, and black-hearted hill Nummulitic Nummulimestone and its subordinate shaley bands form a thick and litic solid basement bed for the rest of the Tertiary system, which attains to a very great thickness and importance all round the north-west frontier of India. From r,000 to 1,500 feet of Nummulitic limestone and shales, followed by 9,000 feet of fresh-water deposits of Murree sandstone and Siwālik sandstones and conglomerates, are bent into long and gentle undulations, and, neglecting the narrow strips of older rocks, cover 90 per cent. of the country to the south of the slate zone and its reversed boundary fault. Near the base of the Nummulitic limestone in Hazāra is a variegated sandstone band with coaly matter, the probable equivalent of the Dandot coal of the Salt Range and that of Jammu. As a source of fuel the Hazãra band has yet to be proved to be of any great value. In the Kohāt salt region ${ }^{1}$ the Nummulitics appear in a long series of inliers, forming ridges from east to west, and with marvellously developed masses of rock-salt, gypsum, and red clay or marls as cores to the anticlinal flexures of these ridges. Mineral oil, found near Mughal Kot, has been described as issuing from the Nummulitic sandstones near their base ${ }^{2}$. The fossils of this great formation still require working out in detail, to bring them into zonal relation with what has been done in Sind and Baluchistān. While the Nummulitic limestone generally occurs in anticlinal arches and ridges of rock, the Siwālik series, composed in its lower part of soft grey sandstone and shales, forms lower-lying country flanking the slopes of the hills, and trough-like synclinals in the valleys. Miocene plant remains are known from the Murree sandstones, and mammalian remains have been gathered here and there from the Siwãlik conglomerate, which ranges up to the pliocene in age.

The post-Tertiary and recent conglomerates, sands, and Post-Teralluvial clays, sometimes reaching 300 feet in thickness, occupy tiary and large areas in the Province, and have grown out of the conditions that caused the Siwalik series. Nearly all the surface of the flat valleys, bordering the present river-beds, and the talus

1 A. B. Wynne, Memoirs, Geological Survey of India, vol. xi, pt. ii.

2 T. H. Holland and T. D. La Touche, Records, Geological Survey of India, vol. xxiv, pt. ii, and vol. $\mathbf{x x}$, pt. iv (2 notes). 
slopes at the foot of the scarps are composed of them. Evidence of old glacial moraines is found at about 6,000 feet in the Kunharr valley, and probably at many other intermediate levels in Kăgān between that and the melting-point of the glaciers of to-day.

Flora. The flora of the plains which occupy the south-east of the Province is practically the same as that of the adjoining portion of the Punjab, its main constituent being shrub jungle with a secondary element of trees and herbs. Among the more common plants of this region are: Flacourtia sapida and $F$. sepiaria, several species of Grewia, Zizyphus nummularia, Acacia Jacquemontii and $A$. leucophloea, Alhagi camelorum, Crotolaria Burhia, Prosopis spicigera, several species of Tamarix, Nerium odorum, Rhazya stricta, Calotropis procera, Periploca aphylla, Tecoma undulata, Lycium europaeum, Withania coagulans and $W$. somnifera, Nannorhops Ritchieana, Fagonia, Tribulus, Peganum Harmala, Calligonum polygonoides, Poly. gonum aviculare and $P$. plebeium, Rumex vesicarius, Crozophora plicata, species of Aristida, Anthistiria, Cenchrus, and Pennisetum.

The arid and stony hills of Waziristān to the west only afford a foothold to a few brave species like Peganum Harmala, Calotropis, Rumex vesicarius, Crozophora plicata, Capparis aphylla, \&c.

Farther north in the Kurram valley the meagre vegetation consists of such plants as Acacia modesta, Tecoma undulata, Sageretia Brandrethiana, Gymnosporia spinosa, Zizyphus vulgaris, Withania coagulans, Periploca aphylla, Nannorhops Ritchieana, and several species of Grewia. On the banks of the Kurram grow species of Tamarix, Dalbergia Sissoo, Nerium odorum, Zizyphus Jujuba and $Z$. oxyphylla, with cultivated examples of mulberry, willow, and nim. Higher up the Kurram Platanus, Celtis, Ebenus stellata, and walnut appear, while the vegetation characteristic of the Punjab becomes less and less conspicuous. Myrtle is also met with here. At altitudes over 2,000 feet Sophora mollis, Daphne oleoides, and Cotoneaster nummularia become prominent features, and up to about 10,000 feet constitute the greater proportion of the vegetation. Other species becoming more common with the rise in altitude are Convolvulus lanuginosus, Onosma echioides, Salvia Moorcroftiana, Astragalus polyacantha, and Otostegia limbata.

The plains north of the Kurram support several species of Astragalus, Onobrychis, Othonnopsis intermedia, Stachys parviflora, Gypsophila Stewartii, Thymus Serpyllum, Convolvulus 
lanuginosus, Isatis tinctoria, Salvia glutinosa and S. rhytidea, as well as those species already mentioned as forming the greater part of the vegetation above 2,000 feet.

On the Safed Koh range, except on its southern aspect, flourish Quercus Ilex, Cotoneaster bacillaris, Buddleia, Desmodium tiliaefolium, Jasminum officinale and J. revolutum, Lonicera quinquelocularis, Abelia triflora, Viburnum cotinifolium, Rhamnus purpureus and $R$. dahuricus, Rosa Webbiana and $R$. moschata, Smilax vaginata, Hedera Helix, Indigofera Gerardiana, Plectranthus rugosus, and Perowskia atriplicifolia. On the sóuthern slopes of the Safed Koh grow Pistacia integerrima and $P$. cabulica, Rhamnus persicus, Rhus Cotinus, Syringa persica, Caragana brevispina, Morina persica, Daphne, Sophora, and Cotoneaster. The vegetation of the Safed Koh above 10,000 feet consists of species of Silene, Primula, Geranium impatiens, Pedicularis, Myrtillus, Lonicera sericea, Isopyrum, Polypodium, Aconitum, and Botrychium. Pinus excelsa and Abies Webbiana grow up to II,000 feet, beyond which altitude the vegetation is composed of bushes of Salix, Rhododendron, Ribes, Juniperus, Rheum Moorcroftianum, and Polygonum rumicifolium.

North of the Kābul river the hills which enclose the Swāt, Dìr, Chitrāl, and other valleys show a curiously mixed flora. In the lower, confined and consequently hot, valleys such as the Swãt and Panjkora flourish quite a number of weeds which one would expect to find only in the plains of India. Among such may be mentioned: Cleome viscosa, Tribulus terrestris, Crotalaria albida, Indigofera pulchella, Aeschynomene indica, Desmodium podocarpum, Luffa echinata, Datura Stramonium, Solanum nigrum, Sesanum indicum, Dicliptera Roxburghiana, Vitex Negundo, Plectranthus rugosus, Anisomeles ovata, Xanthium Strumarium, Sphenoclea zeylanica, Boerhaavia repens, Celosia argentea, Digera arvensis, and Aerua tomentosa, \&c. At higher elevations of about 5,000 to 6,000 feet there are arid tracts resembling the uplands of Baluchistān and supporting a similar vegetation, mainly composed of such plants as Berberis Lysium, Malcolmia, Iris Stocksii, Capparis spinosa, Silene afghanica, Tamarix gallica, Myricaria germanica, Peganum Harmala, Sageretia Brandrethiana, Pistacia, Alhagi camelorum, Sophora mollis, Rosa Beggeriana, Spinacia brahuica, Cotoneaster. bacillaris, Myrrhis, Periploca aphylla, Paracaryum asperum, Daphne oleoides, Salix babylonica, Ixiolirion montanum, Fritillaria imperialis, and Tulipa chrysantha. At higher altitudes of 6,000 feet and upwards the flora resembles. 
that of Kashmir, with the addition of a sprinkling of Central Asiatic and European species. As typical of these higher altitudes may be mentioned several species of Clematis, Thalictrum, Anemone, Ranunculus, Aquilegia, Delphinium, Actaea spicata, and Paeonia anomala. Corydalis, Arabis, and Sisymbrium are each represented by several species. There are three species of Viola. Silene, Cerastium, Stellaria, Geranium impatiens, Prunus, Spiraea, Rubus, Potentilla, Rosa, Pyrus, Crataegus, Sedum, Epilobium, Bupleurum, Pimpinella, Anthriscus, Sonchus, Viburnum, Galium, Asperula, Valeriana, Campanula, Primula, Androsace, Fraxinus, Gentiana, Veronica, Pedicularis, Origanum, Nepeta, Rheum, Ulmus, Quercus, Juniperus, Abies, Pinus, Allium, Gagea, Juncus, Koeleria, Poa, and Secale are all genera representative of the flora of the higher altitudes. Picea Morinda, Abies Webbiana, and Pinus excelsa form forests at higher levels. The prevailing oak is Quercus Ilex. Ferns, chiefly belonging to the genera Adiantum, Pteris, Asplenium, and Nephrodium, are not uncommon; there are, besides, not a few mosses ${ }^{1}$.

Fauna. Tigers used to be common in the Indus valley, but are now quite extinct in the Province; leopards, hyenas, wolves, jackals, and foxes are the chief carnivora. The black, and occasionally the red or brown, bear is found in Hazāra, and monkeys are rare except in that District. The hog deer is found in the Indus valley, the gural, musk deer, barking deer, and ibex in Hazāra, and the 'ravine deer' (Indian gazelle), märkhor, and uriäl in the western hills. Wild hog are found chiefly in the Indus valley.

A large variety of birds, including the Argus and other pheasants and numerous kinds of partridge, are found in Hazāra. In the rest of the Province the chikor, sisi, grey and black partridge, sand-grouse, quail, the demoiselle crane, lesser bustards, geese, duck, and snipe are the chief game birds. Bustards, plovers, pigeons, sand-pipers, and coots are also found. The eagle and lämmergeyer are not uncommon, and there are many varieties of falcons, hawks, and harriers, some of which are tamed for hawking. The sparrow tribe includes fly-catchers, orioles, thrushes, mynas, chats, swallows, larks, tits, and finches.

Many varieties of fish are caught in the Indus, the most

1 J. L. Stewart, Punjab Plants (1869); J. E. T. Aitchison, 'On the Flora of the Kurram Valley,' Journal of the Linnean Society, vols. xviii and xix; J. F. Duthie, 'The Botany of the Chitral Relief Expedition,' Records, Botanical Survey of India, vol. $i$, No. ix. 
important being the mahseer and rohu. Of snakes, the cobra, karait (Echis carinata), and Russell's viper are found, besides other species.

The North-West Frontier Province, stretching southward Climate from the Bāroghil pass in the Hindu Kush, covers nearly and temsix degrees of latitude. Mainly a mountainous region, but perature. including the Peshāwar valley and the broad riverain tract of the Indus in Dera Ismail Khān District, its climatic conditions are extremely diversified, the latter District being one of the hottest areas in the Indian continent, while over the mountain region to the north the weather is temperate in summer and intensely cold in winter. The air is generally dry, and hence the daily and annual ranges of temperature are frequently very large.

The Province has two wet seasons: one, the monsoon, Rainfall. when moisture is brought up by the winds from the Arabian Sea and the Bay of Bengal; the other in winter, when storms from Mesopotamia, Persia, and the Caspian districts bring widespread rain and snowfall. Both sources of supply are precarious, and not infrequently either the winter or summer rainfall fails almost entirely.

In Chitrāl, the extreme north of the Province, the rainfall conditions are those of the temperate zone. The summer rainfall at Chitrāl is light, averaging only 4 inches for the six months May to October, out of which nearly 3 inches fall in the first and last months, while for the rest of the year the rainfall averages ${ }_{3} 3$ inches. Farther south, in the neighbourhood of Peshãwar, the amounts received in the two seasons are approximately equal ; while in the Himālayan District of Hazāra and in Kohāt, Bannu, and Dera Ismail Khān the summer rainfall is distinctly heavier than that of the winter. The area of lightest annual rainfall is the riverain District of Dera Ismail Khān ( 9 inches) and the heaviest that of Hazāra, Abbottābād having a total annual fall of 45 inches. In the central parts of the Province (including Peshāwar) the annual fall ranges from to to 25 inches, while in the north, at Chitrāl, it is about $\mathrm{I} 7$ inches. The winter rains ordinarily fall in the four months January to April, while the summer rainfall, except in Chitrāl, is mainly confined to July and August, the falls in the other months barely averaging half an inch.

During the winter months the wind ordinarily blows from a westerly direction and the weather is fine, with cold nights ; but at intervals the sky clouds over, the wind changes to the southward, the temperature, particularly at night, rises, and 
a storm advances from the west. During its passage the wind is high, and rain and snow fall. After the passage of the storm the weather clears rapidly; a north-westerly wind, chilled by its passage over the snow-clad hills, sets in, and the night temperature falls considerably below freezing-point, even at the plains stations of Peshāwar and Dera Ismail Khān, while at the hill stations the frost on these occasions is very severe. These changes occur at intervals throughout the winter till the end of March. During April and May strong, hot, westerly winds are experienced, the temperature rises quickly, and though storms of the cold-weather type are not unknown during these months, they are now accompanied by lightning and thunder. Towards the end of June the westerly winds die down, the weather becomes close, damp, and steamy, and spasmodic advances of monsoon winds occur, giving occasional heavy downpours of rain, more particularly in Hazāra District. These conditions last, varying according to the strength and extent of the monsoon current in different years, until the middle of September. After that the weather clears, the temperature falls, and the finest and most settled months in the years are usually October and November, when in most parts of the area there is very little rain. The days are hot; but the mornings, evenings, and nights are cool and pleasant. Hailstorms of great violence are common in the late spring and early autumn.

The thermometer rises during the hottest part of the year to between $100^{\circ}$ and $106^{\circ}$ at Cherāt; to between $114^{\circ}$ and $120^{\circ}$ at Peshāwar; to between $115^{\circ}$ and $122^{\circ}$ at Dera Ismail Khān ; to between $104^{\circ}$ and $108^{\circ}$ at Chitrāl ; and to between $97^{\circ}$ and $100^{\circ}$ at Pārachinār. Slight frost is recorded almost every year in the plains, while intense frost is experienced on the hills. At Chitrāl in 1897 the thermometer fell to $5.4^{\circ}$, and the annual range of temperature at that station was close on $100^{\circ}$. At Pārachinār the minimum temperature was $11 \cdot 8^{\circ}$ in r900, while at Peshāwar and Dera Ismail Khān it fell to about $28^{\circ}$ in 1902 , and the annual range at these two stations was about $90^{\circ}$. The lowest temperature recorded was minus $13^{\circ}$ at Wāna in January, 1905 .

History. The key to the history of the North-West Frontier Province The Persians. lies in the recognition of the fact that the valley of Peshāwar was always more closely connected politically with Eastern Irān (the ancient Ariana and modern Afghānistān) than with India, though in pre-Muhammadan times its population was mainly Indian by race. 
Early history finds the Iranians dominating the whole Indus valley. At some date later than 516 B.c. Darius Hystaspes sent Skylax, a Greek seaman of Karyanda, to explore the course of the river, and subsequently subdued the races dwelling west of the Indus and north of Kābul. Gandhāra, the modern District of Peshāwar, was incorporated in a Persian satrapy, and the Assakenoi, with the tribes further north on the Indus, formed a special satrapy, that of the Indians. Both satrapies sent troops for Xerxes' invasion of Greece.

In the spring of 327 B.c. Alexander the Great crossed the The Indian Caucasus (Hindu Kush) and advanced to Nicaea, Greeks. where he was joined by Omphis, king of Taxila, and other chiefs. Thence he dispatched part of his force through the valley of the Kābul river, while he himself advanced into Bājaur and Swāt with his light troops. Craterus was ordered to fortify and repeople Arigaion, probably in Bājaur, which its inhabitants had burnt and deserted. Having defeated the Aspasians, from whom he took 40,000 prisoners and 230,000 oxen, Alexander crossed the Gouraios (Panjkora) and entered the territory of the Assakenoi and laid siege to Massaga, which he took by storm. Ora and Bazira (? Bāzār) soon fell. The people of Bazira fled to the rock Aornos, but Alexander made Embolima (? Amb) his basis, and thence attacked the rock, which was captured after a desperate resistance. Meanwhile, Peukelaotis (in Hashtnagar, 17 miles north-west of Peshāwar) had submitted, and Nicanor, a Macedonian, was appointed satrap of the country west of the Indus. Alexander then crossed that river at Ohind or, according to some writers, lower down near Attock. Nicanor was succeeded as satrap by Philippus, who was, however, assassinated by his Greek mercenaries soon after Alexander left India, and Eudamos and Taxiles were then entrusted with the country west of the Indus. After Alexander's death in 323 B.c. Porus obtained possession of the Lower Indus valley, but was treacherously murdered by Eudamos in 3r7. Eudamos then left India; and with his departure the Macedonian power collapsed, and Sandrocottus (Chandragupta), the founder of the Mauryan dynasty, made himself master of the province. His grandson Asoka made Buddhism the dominant religion in Gandhāra and in Pakhli, the modern Hazāra, as the rock-inscriptions at Shāhbāzgarhi and Mānsehra show.

After Asoka's death the Mauryan empire fell to pieces, just The Bacas in the west the Seleucid power was waning. The Greek ${ }^{\text {trians. }}$ 
princes of Bactria seized the opportunity for declaring their independence, and Demetrius conquered part of Northern India (c. 190 B.c.). His absence led to a revolt by Eucratides, who seized on Bactria proper and finally defeated Demetrius in his eastern possessions. Eucratides was, however, murdered (c. 156 B.c.), and the country became subject to a number of petty rulers, of whom little is known but the names laboriously gathered from their coins. The Bactrian dynasty was attacked from the west by the Parthians and from the north (about $\times 39$ B.c.) by the Sakas, a Central Asian tribe, Local Greek rulers still exercised a feeble and precarious power along the borderland, but the last vestige of Greek dominion was extinguished by the Yueh-chi.

The Ku- This race of nomads had driven the Sakas before them from shans. the highlands of Central Asia, and were themselves forced southwards by the Hiung-nu. One section, known as the Kushan, took the lead, and its chief Kadphises I seized vast territories extending south to the Kābul valley. His son Kadphises II conquered North-Western India, which he governed through his generals. His immediate successors were the kings Kanishka, Huvishka, and Vasushka or Vāsudeva, of whom the first reigned over a territory which extended as far east as Benares and as far south as Mālwã, comprising also Bactria and the Kābul valley. Their dates are still a matter of dispute, but it is beyond question that they reigned early in the Christian era. To this period may be ascribed the fine statues and bas-reliefs found in Gandhāra (Peshāwar) and Udyāna (Buner).

Later Ku- Under Huvishka's successor, Vasushka, the dominions of the shans and White Huns. Kushan kings shrank to the Indus valley and the modern Afghānistān; and their dynasty was supplanted by Ki-to-lo, the chief of a Yueh-chi tribe which had remained in Bactria, but was forced to move to the south of the Hindu Kush by the invasion of the Yuan Yuan. The subjects of Ki-to-lo's successors who ruled in the valley of Peshāwar are known to the Chinese annalists as the Little Yueh-chi. Their rule, however, did not endure, for they were subdued by the Ephthalites (Ye-ta-i-li-to or Ye-tha), who established a vast empire from Chinese Turkistān to Persia, including the Kābul valley. Known to the Byzantines as the White Huns, they waged war against the Sassanid dynasty of Persia. Under Toramāna and Mihirakula they held Northern India, ruling at Sagala, which may be Siālkot in the Punjab. Mihirakula penetrated far into India, but about 528 was defeated by a 
confederacy of Indian princes under Yasodharman, and was driven back to the Punjab and Indus valley.

There were two distinct streams of Muhammadan invasion The Mutowards India. The earlier had resulted in the conquest of hammaKhorãsãn; but, though Kābul had been assailed as early as 655 and made tributary in 683 , it regained its independence before 700 , and the stream of invasion was deflected towards Multān and Sind. Ghazni was only taken in 870 , and in 902 we find the Kashmir forces deposing the rebellious ruler of Udabhandapura (Ohind) and giving his kingdom to Toramāna, son of Lalliya, with the title of Komaluka-the Kamalu of Muhammadan historians. In 974 Pirin, the slave-governor of Ghazni, repulsed a force sent from India to seize that stronghold; and in 977 Sabuktagin, his successor, became virtually independent and founded the dynasty of the Ghaznivids. In 986 he raided the Indian frontier, and in 988 defeated Jaipāl with his allies at Laghmān, and soon after possessed himself of the country up to the Indus, placing a governor of his own at Peshāwar. Mahmūd, Sabuktagin's son, having secured the throne of Ghazni, again defeated Jaipāl in his first raid into India (roor), and in a second expedition defeated Anandpāl (roo6), both near Peshāwar. He also (ro24 and ro25) raided the Afghāns, a name that now appears for the first time as that of a people living in the hills between Ghazni and the Sulaimān range. The present territories of the North-West Frontier Province, excluding Hazāra, thus formed part of the Ghaznivid empire. In II79 Muhammad of Ghor took Peshāwar, The capturing Lahore from Khusrū Malik two years later. After Ghorids. Muhammad was assassinated (r 206), his able general, Tāj-uddin Yalduz, established himself at Ghazni, the Kurram valley being his real stronghold, until he was driven into Hindustān by the Khwārizmis (1215). The latter were in turn overwhelmed by the Mongols in $122 \mathrm{I}$, when Jalāl-ud-din Khwārizmi, defeated on the Indus by Chingiz Khann, retreated into the Sind-Sāgar Doāb, leaving Peshāwar and other provinces to be ravaged by the Mongols. Yet in $\mathrm{I}_{2} 24$ we find Jalāl-ud-din able to appoint Saif-ud-din Hasan, the Karlugh, in charge of Ghazni. To this territory Saif-ud-dīn added Karmăn (Kurram) and Baniān (Bannu), and eventually became independent (1236). In the same year Altamsh set out on an expedition against Baniān, but was compelled by illness to return to Delhi. After his death Saif-ud-din attacked Multān only to be repulsed by the feudatory of Uch, and three years later (1239) the Mongols drove him out of Ghazni and Kurram, 
but he still held Baniān. In his third attempt to take Multãn, he was, however, killed ( 1249 ), whereupon his son Nãsir-ud-din Muhammad became a feudatory of the Mongols, retaining Baniān. Eleven years later (r 260) we find him endeavouring to effect an alliance between his daughter and a son of Ghiyssud-din Balban, and to reconcile the Mongol sovereign with the court of Delhi. By this time the Karlughs had established themselves in the hills.

Timūr. In $\mathbf{3} 398$ Tīmūr set out from Samarkand to invade India. After subduing Kator, now Chitrāl, he made his devastating inroad into the Punjab, returning via Bannu in March, 1399. His expedition established a Mongol overlordship in the province, and he is said to have confirmed his Karlugh regent in the possession of Hazāra. The descendants of Timunr held the province as a dependency of Kandahār, and Shaikh Alī Beg, governor of Kābul under Shāh Rukh, made his power felt even in the Punjab. But with the decay of the Timmurid dynasty their hold on the province relaxed.

The Meanwhile the Afghanns were rising to power. Implacably Afghanns. hostile to the Mongols, they now appear as a political factor. At the close of the fourteenth century they were firmly es. tablished in their present seats south of Kohāt, and in $\mathrm{r}_{45} \mathrm{r}$ Bahlol Lodi's accession to the throne of Delhi gave them a dominant position in Northern India. Somewhat later Bābar's uncle, Mirza Ulugh Beg of Kābul, expelled the Khashi (Khakhai) Afghāns from his kingdom, and compelled them to move eastwards into Peshāwar, Swāt, and Bājaur. After Bābar had seized Kābul he made his first raid into India in $\mathrm{r}_{505}$, marching down the Khyber, through Kohāt, Bannu, Isa Khel, and the Derajāt, returning by the Sakhi Sarwar pass. About 518 he invaded Bājaur and Swāt, but was recalled by an attack on Badakhshān.

The In I $_{5} 19$ Bäbar's aid was invoked by the Gigiannis against Mughals. the Umr Khel Dilazāks (both Pathān tribes), and his victory at Pānipat in 1526 gave him control of the province. On his death in ${ }_{5} 53^{\circ}$ Mirza Kāmrān became a feudatory of Kābul. By his aid the Ghwaria Khel Afghāns overthrew the Dilazāks who were loyal to Humãyūn, and thus obtained control over Peshāwar; but about $\mathrm{r}_{55}$ K Khān Kajū, at the head of a great confederation of Khashi Pathān tribes, defeated the Ghwaria Khel at Shaikh Tapūr. Humāyūn, however, had now overthrown Kāmrān, and in $155^{2}$ he entered Peshāwar, which he garrisoned strongly, so that Khān Kajū laid siege to it in vain. Nevertheless the Mughal hold on these territories was weak 
and often precarious. On Humāyūn's death in 1556 Kābul became the apanage of Mirza Muhammad Hakīm, Akbar's brother, and in $15^{6}{ }_{4}$ he was driven back on Peshāwar by the ruler of Badakhshān, and had to be reinstated by imperial troops. Driven out of Kābul again two years later, he showed his ingratitude by invading the Punjab; but eventually Akbar forgave him, visited Kābul, and restored his authority. When Mirza Hakìm died (1585), Akbar's Rājput general, Kunwar Mān Singh, occupied Peshāwar and Kābul, where the imperial rule was re-established, Mān Singh becoming governor of the province of Kābul.

In 1586 , however, the Mohmands and others revolted under Tribal Jalāla, the Roshānia heretic, and invested Peshāwar. Mān rebellions. Singh, turning to attack them, found the Khyber closed and was repulsed, but subsequently joined Akbar's forces. Meanwhile, the Yüsufzai and Mandaur Afghāns had also fallen under the spell of the Roshānia heresy, and about ${ }_{1587}$ Zain Khān, Kokaltāsh, was dispatched into Swāt and Bājaur to suppress them. The expedition resulted in the disastrous defeat of the Mughals, Bîrbal, Akbar's favourite, being killed. In $\mathrm{I}_{592}$ the Afghāns invested Peshāwar, but Zain Khān relieved the fortress, and in ${ }_{593}$ overran Tìrāh, Swāt, and Bājaur. The Roshānias, however, were still far from subdued. Tīrāh was their great stronghold, and about 1620 a large Mughal force met with a grave defeat in attempting to enter that country by the Sampagha pass. Six years later Ihdād, the Roshānia leader, was killed; but Jahāngīr's death in 1627 was the signal for a general Afghān revolt, and the Roshānias laid siege to Peshāwar in $163^{\circ}$, but distrusting their Afghān allies retreated to Tĩrāh. Mughal authority was thus restored, and Tirāh was invaded and pacified by the imperial troops in an arduous campaign. Shāh Jahān, however, attempted to govern the Afghāns despotically and caused great discontent. Nevertheless Rājā Jagat Singh held Kohāt and Kurram, and thus kept open the communications with Kābul. In 1660 Tîrāh had to be pacified again, and in 1667 the Yūsufzai and Mandaur Afghāns were strong enough to cross the Indus, and were only defeated near Attock. In 1672 Muhammad Amin Khān, Sūbahdār of Kābul, attempted to force the Khyber, and lost his whole army, 40,000 men, with baggage and matériel. Other disasters followed. At Gandāb in 1673 the Afrīdis defeated a second Mughal army, and in 1674 they defeated a third force at Khãpash and drove it into Bãjaur. These reverses brought Aurangzeb in person to Hasan Abdāl, whence 
he dispatched a force to Kohāt, while a second army forced the Khyber. Aurangzeb appears to have adopted a conciliatory policy towards the Afghāns, some of whom now received fiefs from the emperor. This policy and their internal dissensions kept the country in a state of anarchy, but prevented any concerted Afghãn rising against the Mughals.

Decay of Nevertheless the Afghãns overran the Pakhli district of Mughal power. Hazāra early in the eighteenth century and the Mughal power rapidly declined, until in $173^{8} \mathrm{Nādir}$ Shāh defeated Nāzir Shāh, the Mughal governor of Kābul, but allowed him as feudatory to retain that province, which included Peshãwar and Ghazni. Of Nādir Shāh's successors Ahmād Shāh Durrāni indeed established something more nearly approaching a settled government in the Peshāwar valley than had been known for years, but with the advent of Tīmūr Shāh anarchy returned once more. On the death of Tīmūr Shāh his throne was contested with varying fortunes by his sons, whose dissensions gave ample opportunity to the local chieftains throughout the province of establishing complete independence. Peshāwar ultimately fell to the Bãrakzai family; Dera Ismail Khān to the Sadozais.

The Sikhs. The Sikh invasions began in 1818 , and from that date to the annexation by the British the Sikhs under Ranjit Singh were steadily making themselves masters of the country. In 1818 Dera Ismail Khān surrendered to a Sikh army, and five years later the Sikhs harried the Marwat plain of Bannu. In $183^{6}$ all authority was taken from the Nawābs of Dera Ismail Khān and a Sikh Kardār appointed in their place. But it was not till after the first Sikh War that the fort of Bannu was built and the Bannuchis brought under the direct control of the Lahore Darbār by Herbert Edwardes. In 1834, two years after the great Sikh victory over the Afghanns at Naushahra, the famous general Hari Singh took possession of Peshāwar fort, and at the same time Kohāt and Teri were temporarily occupied by Sikh garrisons. These, however, were speedily withdrawn; and the death of Hari Singh in battle with the Afghanns near Jamrūd in 1837 brought home to Ranjit Singh, now nearing the close of his career, the difficulty of administering his frontier acquisitions. On his death the Sikh policy was changed. Turbulent and exposed tracts, like Hashtnagar and Miranzai, were made over in jaggir to the local chieftains, who enjoyed an almost complete independence, and a vigorous administration was attempted only in the more easily controlled areas. Of the Sikh governors, the best remembered is General 
Avitabile, who was in charge of Peshāwar District from 1838 to 1842 .

By the proclamation of March 29,1849 , the frontier The territory was annexed by the British. For a short time the British. Districts of Peshāwar, Kohāt, and Hazāra were under the direct control of the Board of Administration at Lahore, but about $185^{\circ}$ they were formed into a regular Division under a Commissioner. Dera Ismail Khān and Bannu, under one Deputy-Commissioner, formed part of the Leiah Division till I86r, when two Deputy-Commissioners were appointed and both Districts were included in the Derajāt Division, an arrangement which was maintained until the formation of the North-West Frontier Province. The internal administration differed in no way from the rest of the Punjab. But to maintain the peace of the horder a special force-the Punjab Frontier Force-was raised under the direct orders of the Board. It consisted at first of 5 regiments of cavalry, the corps of Guides, 5 regiments of infantry, 3 light field batteries, 2 garrison batteries, 2 companies of sappers and miners, and the Sind camel corps. Various changes were made in the composition of the force, which at length, in 1886 , was removed from the control of the Punjab Government and amalgamated with the regular army.

The attitude of the people during the Mutiny is the highest The tribute that can be paid to the success of the internal adminis- Mutiny. tration. In the history of the frontier the interest of that period of stress centred at Peshāwar. The Hindustāni regiments at Dera Ismail Khān and Kohāt were disarmed without difficulty, and troops and levies were hurried away to strengthen the garrison of Peshāwar or join the British forces cis-Indus. The situation in Peshāwar was very different. The District contained a large Hindustāni force, which proved mutinous to the core. It was thought possible that the Amīr of Kābul might pour an army through the Khyber. For one crime or another almost every powerful tribe beyond the border was under a blockade. When the news of the outbreak reached Peshāwar, a council of war was at once held and measures adopted to meet the situation. The same night the Guides started on their memorable march to Delhi. On May $2 \mathrm{I}$ the $55^{\text {th }}$ Native Infantry rose at Mardān. The majority made good their escape across the Indus, only to perish after fearful privations at the hands of the hill-men of the Hazāra border. On May 22, warned by this example, the authorities of Peshāwar disarmed the $24^{\text {th }}, 27^{\text {th }}$, and 5 Ist Native Infantry, 
with the result that Pathāns not only of Peshāwar, but also from across the border, came flocking in to join the newly raised levies. The next few months were not without incident, though the crisis was past. When the Mutiny was finally suppressed, it was clear that the frontier Districts had proved to the British Government a source of strength rather than of danger.

Expedi- A complete list of all expeditions undertaken against the

tions

against

frontier

tribes.

$1849-57$.

1857-78. Of all the frontier tribes only a few Yüsufzai villages within the British border took advantage of the difficulties of 1857 . They were speedily punished, Narinji, the centre of disturbance, being stormed and razed to the ground. In the next year the misbehaviour of the Khudu Khel, roused by emissaries from the Hindustāni fanatics, compelled an invasion of their country, from which the fanatical colony was expelled. In $1859-60$ operations were undertaken in the country of the Kābul Wazirs between Thal and Bannu; and in r860 the Mahsūd country was overrun, in punishment for a long series of outrages, culminating in an attempt to plunder and burn the border town of Tānk. The tribe, however, did not submit, and after the withdrawal of the troops was put under blockade. Different sections of the tribe, and from 1877 onwards the whole of it, remained under embargo, on account of repeated violations of British territory, almost without intermission, until the next expedition was undertaken in $\mathbf{r} 88 \mathrm{I}$.

In 1863 took place the Ambela campaign. Repeated robberies in British territory had led to a blockade on the Yūsufzai border, and blockade in turn had caused the denunciation of the infidel and the proclamation of jika $\bar{d} d$ in all the high places between Swāt and the Hazāra border. Swāt itself was at this time controlled by the famous Akhund, who had had experience of the strength of the Government, and whose inclinations were consequently for peace, especially as a religious rivalry prevailed between him and the head of the fanatical colony. Even in Swāt, however, intense excitement was rife. The object of the expedition was to root out the colony of Hindustāni fanatics which since $185^{8}$ had been located in the 
Barandu valley, and was recognized as a permanent source of danger and disturbance. The troops gained the crest of the Ambela pass leading to the Chamla valley, and thence advanced to Mãlka, when they encountered unexpected opposition from the Bunerwāls whose country lies immediately north of Chamla. The Akhund was no longer able to stem the tide, and joined the enemy's camp, followed by standards from all the tribes of Swāt, Dīr, Bājaur, and by contingents from the Utman Khel and the Mohmands as well as by some British subjects. For more than a month the British force, though raised by successive additions to a strength of more than 9,000 men, could not do more than hold its ground. But with the passage of time the coalition of the enemy began to fall asunder, and on the repulse with heavy slaughter of the last of a long series of attacks the object of the expedition was achieved. The Bunerwāls agreed to destroy Mālka and drive out the fanatics, and exclude them from their country for ever. From r 863 to 1893 the fanatics wandered to and fro in the Chagarzai, Hasanzai, and Madda Khel (Yūsufzai) country; and since 1893 they have lived mainly in the Amazai territory in Buner, but they have lost most of their political importance. Other operations in this period do not require detailed mention; but the Black Mountain expedition of 1868 , in which the British force numbered nearly 15,000 men (including the reserve), was noteworthy, more perhaps from the audacious provocation given, the strength of the force used, and the difficulty of the country traversed, than from the stubbornness of the eneny or the permanence of the results secured.

An account of the second Afghān War will be found in the Second article on AFGHĀnistān. Its importance lay chiefly in the Afghān imperial issues involved, but it marks an inportant stage in the ${ }_{1878-80}$. relations of the British with the frontier tribes. By the Treaty of Gandamak (May, I879) the Amīr Yakūb Khān renounced his claim to authority over the Khyber and Mohmand passes, the tribes flanking the main routes into India, the Kurram valley as far as the Shutargardan pass, and the districts of Pishīn and Sibi in Baluchistān.

Between the outbreak of the second Afghān War and the ExpediPathān revolt of 1897 there were sixteen expeditions against the frontier tribes. Of these eight took place before peace tions, $187^{8}-97$. was concluded with Kābul, and were in the nature of punishment inflicted on the clans. The expedition of 1881 against the Mahsūds was more noteworthy, and produced comparative peace on this part of the border for five years. Between 1888 
and 1892 , the Hazāra border was disturbed almost continuously, and large expeditions were dispatched against the Isazai clans of the Black Mountain, and their neighbours, the Cis-Indus Swātis, Alatis, and Parari Saiyids. Little resistance was offered to the troops, and the expeditions were completely successful. The first and second Miñanzai expeditions of 1891 were directed against the Orakzai tribes living along the crest of the Sāmanna. There was little fighting, but the expedition resulted in the occupation of posts along that range; and, except in r 897 , there has been no trouble since then on the Orakzai border.

In 1894 the deputation of the Commissioner of the Derajāt to demarcate the border between Wazīistān and Afghān territory, and the invitation extended by the Ahmadzai of Wāna to the Government to occupy their country, led to an attack by the Mahsūds, under the leadership of the Mulla Powinda, on the Commissioner's escort, in the Wāna plain. An expedition followed, which effected the submission of the tribe. Since r894 Wāna has been occupied, and parts of Southern Wazīristān have been administered by the Political officer in charge. An account of the Chitrāl expedition of 1895 will be found in the article on CHITRĀL.

Pathān re- The summer of 1897 found the border in an inflammable volt, 1897 . condition. Exaggerated accounts had been circulated of the successes gained by the Turkish armies in their war against Greece, while the growth of a fanatical spirit was fostered by the Mullās, and by the belief that aid would be forthcoming from Käbul. Apart from these reasons for religious excitement, the operations taken to demarcate the new Durand line, referred to below, and the occupation of the Sāmanna range, the Kurram valley, Daur, and Wāna, the passage of British troops through various tracts, and administrative grievances, such as the tax on Kohāt salt, added to the discontent of the tribesmen. The prevalent excitement first sprang into flame

In Tochi. in Tochi. An unexpected visit from the Political officer, accompanied by an unusually strong escort, on June ro, to the village of Maizar, of which the inhabitants were already in disgrace for the murder of a Hindu, caused the explosion. After being hospitably entertained, the troops were treacherously attacked. All the British military officers were killed or wounded, but the escort, with the Political officer, withdrew in good order to Datta Khel.

In Swät. The news spread rapidly and everywhere formed the text of fanatical harangues by Mullās, and in particular by a Buner- 
wāl of Upper Swāt named Sād-ullah, whose eccentricities had earned hin the name of the Mullā Mastān ('mad'). On July 26 , followed only by a few boys, one of whom he proclaimed king of Delhi, he started from Landakai, a village about 6 miles above Chakdarra on the south bank of the Swät river. The tribesmen flocked after him, and by evening, with ever-increasing numbers, the gathering approached the Malakand. A sudden attack was made on the Malakand and Chakdarra simultaneously. The numbers, which at first had barely reached 1,000 men, were rapidly swollen to 12,000 at the Malakand and 8,000 at Chakdarra. Heavy fighting continued at both places, until the Malakand was relieved on August $I$ and Chakdarra on the 2nd. The assailants then drew off with a loss of not less than 3,000 men, while the British losses had amounted to 33 killed and 188 wounded. On the relief of Chakdarra the gathering quickly dispersed, and the task of punishment and prevention of further combination was taken in hand at once.

The next to rise were the Mohmands. Animated by the The Mohdiscourses of Najm-ud-din, the Adda Mullā, a gathering of mands. about 5,000 armed men from all sections (except the Tarakzai) advanced on August 7 into the Peshāwar valley, and attacked the village of Shankargarh, in which there is a large Hindu element, and the adjoining police post of Shabkadar. Troops were dispatched from Peshāwar, and the tribesmen were driven back into the hills.

Meanwhile, throughout Afrīdi and Orakzai Tīrāh the excite- Tìrāh. ment had been growing; and frequent rumours reached Peshāwar, Kohāt, and Kurram of the reconciliation of intertribal feuds and the gathering of clans for $j i h \bar{a} d$, at the bidding of Mullā Saiyid Akbar, Aka Khel Afrīdi. The trouble began with desultory firing by the Orakzai at the troops on the Sāmanna on August I5. By the $23^{\text {rd }}$ and $24^{\text {th }}$ the whole of the posts in the Khyber, held only by the Khyber Rifles, whose British officers had been withdrawn, fell before a strong combination of Afridis. By the end of the month the Orakzai and Afrīdis had collected I 5,000 men, all the posts on the Sāmāna were closely invested, Shināwari (a police post at the juncture of Upper and Lower Mīrānzai) had fallen, and Hangu was threatened. The siege of the Sāmāna posts continued till September 14, when Fort Lockhart and Fort Cavagnari (Gulistān) were relieved, the small post of Sãragarhi having fallen on September I 2. On the approach of the relief force the enemy withdrew from the Sāmāna ridge into the Khãnki valley. 
I'unitive These unprovoked attacks, which had not been without operations. success, involved active military operations as a punishment and a deterrent. The operations began with the dispatch of two brigades ( 7,000 men) to Datta Khel in the Tochi valley, which caused the submission of the Madda Khel, who agreed to give up seventeen ringleaders, make compensation for the property taken at Maizar, and pay a fine. The final submission was, however, not concluded till r9or, after further operations.

In Swāt a quicker settlement was made. Before the end of the year Upper Swāt, Bãjaur, Chamla, and the Utman Khel country had been penetrated by British troops, and the fines imposed had been realized. In January, 1898 , an expedition was sent through Buner, fines were realized from the Khudu Khel and Gadūns of the Yũsufzai border, and the Mullā Mastān was expelled by political pressure from Dīr and Swăt. The Malakand Field Force consisted of three brigades with the usual complement of divisional troops, in all ro, 000 men.

The punishment of the Mohmands was effected by two brigades ( 7,000 men) advancing from Peshāwar, in co-operation with two others detached from the Malakand Field Force. Difficulties were encountered in the advance of the latter, during which the affair at Inayyat Kila took place ; but before the end of October the Mohmands had been punished, and the Adda Mullā fled to Afghannistān. On his departure a fine was paid by the tribe and weapons were surrendered.

Tĩrāh was invaded from Miraanzai by the route passing from Shinwāri over the Chagru Kotal, between the cliffs of Dargai and the Sāmāna Sukh. The army consisted of two divisions, under Sir W. Lockhart, supported by columns at Peshāwar and in the Kurram. The advance began on October 18 , and on the 2 rst was fought the severe action of Dargai, in which the British loss was 38 killed and $r 9 r$ wounded. The troops then penetrated to Maidān and Bārā. By December 20, the Orakzai had completely fulfilled their obligations, but the Afridis, who had as yet received little punishment, held out. Their territories were, therefore, still further harried; but the demands of the Government were not complied, with till April, 1898 , and the posts in the Khyber were held by regular troops till December, 1899 , when they were made over to the Khyber Rifles. About 30,000 men were employed in the Tiranh campaign, which had taken place in a difficult and unknown country, with an enemy who gave the troops no rest and pressed 
close on the heels of every retirement, while cleverly avoiding resistance in strength to an advance.

Since the conclusion of peace with the Afridis in 1898 , the $1898-$ border from the Kurram northwards has been undisturbed. In Wazīistān the period has also been marked by increasing tranquillity, but on three occasions troops have been required. On December I, I900, the Mahsūds, whose behaviour had been very unsatisfactory, were put under strict blockade. As the tribe continued its depredations, their country was harried during the winter of $190 \mathrm{I}-2$ by constant incursions of lightly equipped columns. In the spring the fines imposed were paid, stolen rifles were surrendered, and security was given for the fulfilment of the other terms demanded. Since this settlement the behaviour of the Mahsūds, as a tribe, has been conspicuously good, though three British officers were murdered by individuals in 1904-5.

In r 9or troops were marched through the Madda Khel country, in North Waziristān, to enforce complete compliance with the terms imposed in 1897 . The operations were successful.

In the autumn of 1902 an incursion was made into the Kābul Khel country from Thal, Idak, and Bannu. There was little fighting except with a band of outlaws at Gumatti, but severe punishment was inflicted on the tribe, with excellent results.

By the terms of the Treaty of Gandamak, the linits of the Durand Afghân sphere of influence were set back along the main lines line. between India and Kābul to the western ends of the Khyber Pass and the Kurram valley, but north and south of these routes no boundary was fixed. At intervals during their history some measure of control had been exercised over the Pathan tribes from Kābul, and the more important of them, such as the Afridis and Mohmands, had been in receipt of allowances from the Amīr for keeping open the passes. But practically they had been independent, and their main object has always been to remain so. In 1893 the Amir consented to a precise fixing of boundaries, and a mission, under Sir Mortimer Durand, proceeded to Kābul to discuss the question. An agreement was signed definitely fixing 'the line which the Government of India and the Amir have agreed to regard as the frontier of Afghānistann from Chandak (in the valley of the Kunar river, 12 miles north of Asmār) to the Persian border.' Commissions were next issued to demarcate the boundary. The Asmār Commission (1894) demarcated from the Bashgal valley on the borders of Kāfiristān to Nawā Kotal, a point on the confines 
of Bãjaur and the Mohmand country. This delimitation was accepted by both governments; but south of the Nawã Kotal no demarcation was made, owing to disagreement, the Amir being unwilling to admit the boundary framed by the Durand agreement in the Mohmand territory. Between the Kābul river and Sikarām (Safed Koh) no demarcation was attempted. But in the same year (1894) boundary stones were set up on the Kurram border, and orders were issued for demarcation from the Kurram to the Gomal river, which led to the Mahsūd expedition already mentioned. In 1895 this demarcation was carried out, after which no further work on the boundary has been undertaken.

Formation From annexation till Igor the Pathān frontier was under of the North-

West Frontier Province. the control of the Punjab Government. Various schemes had been propounded for an alteration of this arrangement, with the double object of securing closer and more immediate control and supervision of the frontier by the Supreme Government, and of making such alterations in the personnel and duties of frontier officials as would tend to the establishment of improved relations between the local British representatives and the independent tribesmen. Of these schemes the most notable was that formulated by Lord Lytton in 1877 , which was laid aside on the outbreak of the second Afghan War in the following year. The question was raised again, in consequence of the experiences of 1897 ; and after mature discussion and deliberation a scheme was formulated by which the Districts of Hazāra, Peshāwar, and Kohāt, together with the Trans-Indus portions of Bannu and Dera Ismail Khān, and the Political Agencies in the Khyber, the Kurram, the Tochi, and Wāna were removed from the control of the Punjab Administration. To these areas was added the political charge of Dìr, Swāt, and Chitrāl, the Political Agent of which had never been subordinate to the Punjab. The new Province was constituted in I 901 , under a Chief Commissioner and Agent to the GovernorGeneral, with head-quarters at Peshāwar, in direct communication with the Government of India in the Foreign Department. In political questions there is no intermediary between the Chief Commissioner and the local officer-an arrangement designed to secure both prompt disposal of references and the utilization of the expert knowledge of frontier conditions for which the head of the administration is selected.

Archae- The northern portion of what is now the North-West Frontier ology. Province corresponds fairly closely with the ancient kingdoms of Udyāna (Swāt) and Gandhāra (Peshāwar), while Kurran 
has been identified with the $\mathrm{Ki}$ Kiangha of Hiuen Tsiang, and Bannu with the country called by him Falana, probably a Chinese transcription of a Sanskrit form Varna or Barna.

Objects of archaeological interest are not uncommon in all these regions, and may be divided into two main categories: those which date from the era before the Muhammadan conquest (rooo), and those of more recent origin. The former are generically described as Buddhist or Graeco-Buddhist. Consisting of well-graded roads, rock-inscriptions for the preservation of royal edicts, massive buildings, and sculptures of an almost Hellenic elegance, they form an unmistakable record of the high degree of many-sided civilization to which the people had attained before the advent of Islām. The antiquities of the Muhammadan era, on the other hand, with the exception of a building in Peshāwar city known as the Gorkhatri, which takes its name from a Hindu shrine, consist chiefly of mosques, tombs, and shrines, buildings of an exclusively religious nature, which evince no marked culture in the builders.

Of ancient roads the best known are to be found on the Buddhist Kohāt, Malakand, and Shāhkot passes, where they are still used remains. for the passage of pack-animals. Ruined structures of a massive type of architecture, some of which have been recognized as forts, others as monasteries and stüpas, exist at many places. Of these the most famous are the ruins on Mount Banj in Gadun territory (identified by Dr. Stein as the famous place of Buddhist pilgrimage, the scene of Buddha's body offering); those at Chārsadda, Naogrām, Jamāl Garhi, Kharaki, Takht-iBahai, Sāhri Bahlol, Tiralai in Peshāwar District, Adh-i-Samudh near Kohāt, the Akra mound in Bannu, and Kāfir Kot in Dera Ismail Khān. From the sites in Peshāwar District, and to the north of it, many valuable finds of coins, inscriptions, and sculptures have been made at different times; and from the evidence afforded by these, such knowledge as we have of the ancient kingdoms of Udyāna and Gandhāra and their dynasties is largely derived. Perhaps the most valuable relics of all from this point of view are the famous Kharoshthi rock-inscriptions at Shāhbāzgarhi in Peshāwar District and Mānsehra in Hazāra. These have been deciphered as slightly variant versions of a series of edicts published about 250 B.C. under the orders of king Asoka, the grandson of Chandragupta, or Sandrocottus, the renowned antagonist of Seleucus, Alexander's general. PreMuhammadan buildings, still extant in other parts of the Province, such as Adh-i-Samudh and Kāfir Kot, have not been equally distinguished by such finds. They appear to be of 
more recent construction than the remains in the northern regions, and to have been used more exclusively for defensive purposes.

Later Among later buildings mention has already been made of the buildings. Gorkhatri, once a place of Hindu pilgrimage, to which reference is made in Bābar's Memoirs. The present building was erected as a resthouse for travellers under the orders of Nür Mahal, queen of the emperor Jahāngìr. The Gorkhatri, once the residence of General Avitabile, who governed Peshāwar in the days of Sikh rule, is now used as a tahsil office. Besides this and the mosque named after Muhabbat Khān, a Mughal governor of Peshāwar, and the country seat of Ali Mardān Khān Durrāni, now in the middle of cantonments and used as the District treasury, neither Peshāwar nor any other District of the Province can boast of any buildings of later date than the eleventh century possessing either architectural pretensions or historical interest.

Popula- The population of the Province as enumerated in 1901 was tion. Census statistics. $2,125,480$; but this figure includes merely the population of the five British Districts, the Kurram Agency, and the Shirāni country, only the military posts in the remaining territories having been enumerated. In Ig03 a Census was taken in the Tochi valley, which was found to contain a resident population of 24,670 . It may be estimated that the whole Province has a population of nearly four millions.

Density. In the administered Districts the density of the population per square mile rose to 152 in 190 from 148 in 1891 . The fertile valley of Peshāwar supports 330 persons to the square mile, Dera Ismail Khān being the most sparsely populated District with 74, while the Kurram Agency has only 42.

'Townsand Of the population enumerated in 1901, 269,905 lived in villages. towns and $1,855,575$ in rural areas. The Province contains one city, Peshāwar, its capital (population, 95, 147, including $2 \mathrm{r}, 804$ in cantonments), and four towns with more than ro, 000 inhabitants : namely, Dera Ismail Khān $(31,737)$, Kohāt $(30,762)$, Bannu (14,291), and Chārsadda $(20,235)$. The first three include large cantonments. The Province has ${ }_{5} 5$ smaller towns and 3,348 villages, 1,067 of which contain over 500 inhabitants each. The insecurity of life and property in former days compelled the people to build large villages and fortify them strongly, but there is now a marked tendency to found new homesteads which gradually grow into hamlets. This is specially noticeable in Hazāra and Kohāt. Across the administrative border almost every family has its walled homestead, 
and the villages often consist of a number of towers or hamlets fortified against one another as much as against external enemies.

During the ten years $189 \mathrm{I}-190 \mathrm{r}$ the population in the Growth of British Districts rose from $\mathrm{I}, 857,504$ to $2,04 \mathrm{I}, 493$, an increase populaof 9.9 per cent. Since $188 \mathrm{r}$ there has been an increase of 30.2 per cent. Precise comparison with the figures of 1868 and $\mathbf{r} 85$ is not possible, but the increase since the latter year has undoubtedly been very great, especially in Peshäwar. In the decade $189 \mathrm{I}-\mathrm{rg}$ (1) the increase of the population was almost entirely in the rural areas, the tendency being for the smaller towns to remain stationary or even to decrease. Pesh$\bar{a}$ war city, however, increased from 84, rg r to $95, \mathrm{r} 47$. The population of the Province is still largely immigrant, though less so than formerly. More than 241,000 immigrants, of whom 76,000 came from Afghānistān, were enumerated in I $90 \mathrm{r}$, but against these have to be set off 87,000 emigrants. Neither the immigrants nor the emigrants are more than sojourners who spend the winter months away from their homes, trading, pasturing, or in less reputable employment. After annexation the Districts of the Province were to a large extent colonized by settlers from the tribal territories beyond the border and from Afghannistān. The stream of immigration from these sources is now weakening, the descendants of the first settlers having occupied most of the cultivable area. Thus the population of the Districts is far more stable than it was a generation or two ago.

The age returns of the Province are even more untrust-Age worthy than in other parts of India. At the Census of $190 \mathrm{r}$ statistics. the mean age of the population was 23.8 for males and 23 for females. These figures are low according to European standards and below the corresponding figures in the Punjab, but the age return is probably too inaccurate for any conclusions to be drawn. The mean age of Muhammadans is lower than that of Hindus, a fact explained by the larger number of children among the former. The number of children under ten is high, being 3,032 (compared with 2,653 in the Punjab) in every 10,000 of the population.

The registration of births and deaths is defective, perhaps vital on account of the alleged reluctance of Pathāns to register the statistics. birth of a girl. Vital statistics are collected by the police in rural tracts, and by municipal officials in municipalities. 'The table on the next page shows the principal vital statistics for the Province. 


\begin{tabular}{|c|c|c|c|c|c|c|c|}
\hline Year. & $\begin{array}{c}\text { Population } \\
\text { under re- } \\
\text { gistration. }\end{array}$ & $\begin{array}{c}\text { Ratio of } \\
\text { registered } \\
\text { births per } \\
1,000 .\end{array}$ & $\begin{array}{c}\text { Ratio of } \\
\text { registered } \\
\text { deaths per } \\
1,000 .\end{array}$ & \multicolumn{3}{|c|}{ Deaths per 1,000 from } \\
\cline { 2 - 2 } & Cholera. & $\begin{array}{l}\text { Small- } \\
\text { pox. }\end{array}$ & Fever. & $\begin{array}{c}\text { Bowel } \\
\text { com- } \\
\text { plaints. }\end{array}$ \\
\hline 1881 & $1,590,637$ & 21.73 & 19.04 & 0.01 & 2.07 & 13.05 & 0.56 \\
1891 & $1,790,401$ & 23.37 & 26.04 & 2.19 & 0.40 & $19 \cdot 33$ & 0.29 \\
1901 & $2,046,109$ & 29.5 & 19.2 & 0.06 & 0.47 & $14 \cdot 3$ & 0.19 \\
1904 & $1,990,744$ & 34.9 & 28.6 & 0.00 & 0.8 & 22.3 & 0.3 \\
\hline
\end{tabular}

Diseases. Malarial fever is rife in the autumn months in all the Districts and in the valleys across the border. The virulent type which resembles cholera and is known as Peshāwar fever still occurs in that District, though it is less prevalent than formerly. Autumnal fever frequently assumes a malignant form in Dera Ismail Khān. Diseases of the lungs, though less fatal than fever, often cause heavy mortality in the winter months. Small-pox is not responsible for many deaths. Stone is common throughout the Province. Goitre affects those who drink water from the hill streams, and guinea-worm those who use tank-water. Eye-affections are peculiarly common in the hot, dry Districts of Bannu and Dera Ismail Khān.

Epidemics. Typhus in epidemic form has visited Peshāwar nine times in the past fifteen years. Cholera is an occasional visitant. Until the spring of 1906 the Province remained free from plague except for a few imported cases. The disease then appeared in a virulent form, but its ravages were confined to a small area of the plains portion of Hazāra District. The Trans-Indus Districts and Agencies have so far escaped altogether.

Infant The recorded rates of infant mortality ( 156 males and mortality. I 2 I females per I, 000 births in I901) would compare favourSex
statistics. ably with those in the Punjab if the registration were not defective. Although female infanticide is not suspected, the births reported show a marked excess of males over females, 120 boys being born to roo girls. This is attributed by some to the reluctance of Pathanns to report the birth of a girl. Of the $2,125,480$ persons enumerated in $1901,1,159,306$ or 54.5 per cent. were males and 966,174 or 45.5 females. In other words, there were 834 females to every 1,000 males. In 189 I the ratio was 843 .

Statistics of civil condition.
Among Muhammadans marriage is a civil contract. Among Hindus it is in theory a sacrament and the tie is dissolved only by death, and in the wife's case not even by death; but in the frontier Districts there is much laxity in practice. Women 
here do not occupy a high position; but custom, which is preferred to Muhammadan law by the courts in all cases where the parties are agriculturists, gives to widows and unmarried daughters in the presence of male heirs a right of maintenance only, and in their absence a life interest. A wife is almost invariably purchased, her price being determined by her looks. Infant marriage is unknown among the Muhammadan tribes on the frontier. Divorce for infidelity is not uncommon; but a Pathān, as a rule, considers it due to his honour to kill both the unfaithful wife and her paramour, though in certain circumstancés he will be content with lopping the foot of the latter. Across the border divorcees and widows are not infrequently sold by the husband, or by his heir as the case may be, a Pathān's mother being a realizable asset. There is no prejudice against widow remarriage. The following table gives statistics of civil condition as recorded in 1891 and 1901:-

\begin{tabular}{|c|c|c|c|c|c|c|}
\hline \multirow{2}{*}{$\begin{array}{c}\text { Civil } \\
\text { condition. }\end{array}$} & \multicolumn{3}{|c|}{1891.} & \multicolumn{3}{|c|}{ I901. } \\
\hline & Persons. & Males. & Females. & Persons. & Males. & Females. \\
\hline $\begin{array}{l}\text { Unmarried } \\
\text { Married } \\
\text { Widowed: }\end{array}$ & $\begin{array}{l}971,097 \\
741,483 \\
144,9^{24}\end{array}$ & $\begin{array}{r}5^{87}, 889 \\
373,789 \\
45,965\end{array}$ & $\begin{array}{r}383,208 \\
367,694 \\
98,959\end{array}$ & $\begin{array}{r}1,100,608 \\
851,385 \\
159,968\end{array}$ & $\begin{array}{r}667,635 \\
432,37^{2} \\
51,505\end{array}$ & $\begin{array}{l}432,973 \\
419,013 \\
108,463\end{array}$ \\
\hline
\end{tabular}

The figures show that social conditions have changed little since r89r. Marriage is less general than in the Punjab, a natural result of the avoidance of early marriage.

The dominant language of the Province is Pashtū, which Language. belongs to the Iranian branch of the Aryan family of speech. It has two main dialects: a hard or north-eastern (Pakhto), and a soft or south-western (Pashto). The dividing line of these two dialects runs westwards from Thal through Kohāt District almost to the Indus, but then turns northward, and the speech of the Akhora Khattaks is the soft Pashtū. Thus, Pakhto is spoken in Bājaur, Swāt, and Buner, and by the Yūsufzai, Bangash Orakzai, Afrīdi, and Mohnand Pathāns, while the Khattaks, Wazirs, Marwats, and various minor tribes in the south speak Pashto. It has been asserted that this division of the language corresponds roughly with the tribal systems of the Pathāns, those who speak the hard or north-eastern Pakhto having a tendency to an oligarchic form of government, while the Pashto-speaking branch is intensely democratic in organization.

The classical dialect is that of the Yussufzai, in which the 
earliest Pashtū works were composed. It is the purest and clearest form of the language. The sub-dialects of the Utman Khel tribe, of Bājaur, and of the Afridis and Orakzai differ but little from it, though each has its own accent, and there are local differences in vocabulary. The Wazīrs have several patois, which are probably less removed from the speech of the original Pathāns than the present standard dialect of Peshāwar, and they have retained many words still found in Punjābi. Round Kānigoram in Wazīristān, Bargista, or Ormurī, an independent Iranian language, is spoken by the Ormurs. The conquered strata of the population on the frontier speak Indian dialects, called Hindkī in the north and Jatki or the Jat speech in the south, while Gūjari is spoken by many of the Güjars, who are numerous in the hills of Hazāra and to the north of Peshāwar. In the Swāt Kohistān, Garhwī and Torwālī are spoken; and the Bashkaris of the upper portion of the Panjkora Kohistān speak Bashkarī, which is said to be the same as Garhwi. Of these two dialects little is as yet known.

The following table gives the chief figures returned for languages in the territories enumerated in $189 \mathrm{r}$ and 1901 :-

\begin{tabular}{|c|c|c|c|c|}
\hline \multicolumn{3}{|c|}{ Language spoken. } & \multicolumn{2}{|c|}{ Persons. } \\
\hline & & & $189 \mathrm{x}$. & 1901. \\
\hline Pashtū & • & & $1,005,195$ & $I, 142,869$ \\
\hline Western Punjābi . & & & $17^{2}, 4^{12}$ & $5^{8} 1,713$ \\
\hline Punjābi & . & & 649,449 & $300,5^{87}$ \\
\hline Gūjarī & $\theta^{\circ}$ & - & . . . & 53,021 \\
\hline Wéstern Hindkī. & - & • & ${ }^{15}, I_{3} \mathrm{I}$ & 16,775 \\
\hline
\end{tabular}

Castes and The population contains several ethnological strata, repretribes. senting the deposits formed by different streams of immigration or invasion. Most numerous and important are the Pathāns (Pakhtanna), who regard themselves as the dominant class, and form the majority of the agricultural population in Peshāwar, Kohāt, and Bannu, while beyond the administrative border they are in exclusive possession from Chitrāl to the Gomal. In Hazāra, Gūjars and other tribes of Indian origin predominate, while Dera Ismail Khān is inhabited mainly by Jats.

The Pathān is not now a racial term, whatever its original signifiPathāns. cance may have been. It now denotes status, and is said in Swāt and Dir to describe one who possesses a share in the tribal estate and who has therefore a voice in the village and tribal councils. One who has lost his share is called a fakir, forfeits the name of Pathān, and has no voice in the councils. The Pathān tribes are mainly of Iranian origin, but many of 
their sections are affiliated clans of Hindkī or indigenous descent, others of Saiyid (Arabian), and a few possibly of Turkish origin. The Pathāns in the settled Districts and Kurram numbered 883,779 , or more than two-fifths of the population, in 1901 .

Next in numerical importance come the Awāns or vassals Awāns, \&c. with 24I,000, mainly in Hazãra and the Peshāwar valley. The Gūjars number 108,000 , of whom 92,000 are in Hazāra. They are also numerous in Dïr, Swāt, and Bãjaur, where they speak Pashtū, though on the borders of Dĩr and Asmār they retain their Indian speech. Other less numerous tribes are the Jats $(81,000)$, mostly in Dera Ismail Khān, Saiyids $(77,000)$, Tanaolis $(62,000$, immigrants from TANĀWAL), Malliārs $(27,000)$, Dhunds $(25,000)$, Balochs $(24,000)$, Rājputs $(20,000)$, Shaikhs (19,000), Kharrals (16,000), Mughals (14,000), Kureshis (I 4,000), Bãghbāns (I 2,000), Parãchas (I I , ০oo), Kassābs $(7,000)$, Sureras $(7,000)$, and Gakhars $(6,000)$. Of Hindu castes, the Aroras $(69,000)$, Khattrīs $(34,000)$, and Brāhmans $(15,000)$ are important. In tribal territory, besides the tribes already alluded to, the Torwāl and Garhwi reside in the higher ranges of Swāt and the Bashkarī in the Panjkora hills. In Jandol and Maidān are various other tribes of Kāfir descent converted to Islām, and now reckoned as Pathāns.

Of the artisan classes the most numerous are the Tarkhāns or carpenters $(40,000)$, some of whom are rising under British rule to the status of a professional class as trained engineers. Next to them in numerical strength are the Julāhās (weavers, 38,000 ), then come the Lohārs (blacksmiths, 27,000 ), Mochīs (leather-workers and shoemakers, 23,000), Kumhärs (potters and brick-burners, 20,000), Sonārs (goldsmiths), and Telis (oil-pressers, 10,000). The Kashmiris (wool-weavers and general labourers) number 25,000. Of the menial classes, the Nais (barbers) stand first numerically with 24,000 . Next to them come the scavengers, 22,000 in all. Other menial classes are the Dhobis and Chhīmbās (washermen, I 7,000), and the Mīrāsīs or Dums (village minstrels, 1 1,000).

The predominance of Islām may be gauged by the fact that Religions. $1,957,777$ persons, or 92 per cent. of the population enumerated in r 901 , were returned as Muhammadans. In the tribal areas not enumerated its importance is still more marked, though Hindu traders are found even in the wildest tracts and receive ample toleration from their Muhammadan overlords. Tīrāh has a colony of Sikhs. The Muhammadans are mainly Sunnis, less than one per cent. confessing the Shiah tenets, though the 
Turis and some of the Bangash tribes in Kurram are avowed Shiahs, as are many of the Orakzai Pathāns in Tirāh, and the sect is also found in Kohāt and the Shirāni country. The Shiahs are chiefly distinguished by the reverence they pay to Saiyids as descendants of Alī, while among the Sunnis Mullās or priests exercise supreme influence. Fanaticism is violent throughout the Province. As preached by the Mullās, Islām is a religion of gloom, songs and dancing being condemned by them, while a sombre fanaticism, compatible with a degraded morality, is inculcated. Shrines abound and are objects of pilgrimages, fairs being held at each on specified days. The shrines are of saints who have obtained a reputation for miraculous powers or spiritual excellence. They are so numerous that few possess special eminence, but those of the Akhund of Swāt and of the Pīr Bāba in Buner attract pilgrims from all parts of the Muhammadan world. At most shrines bodily ailments may be cured or other advantages obtained.

Christian Of the total population of the Province only 5,273 (including missions. 533 natives), or 0.25 per cent., were returned as Christians in 1901. The Church Missionary Society has flourishing stations at Peshāwar and Bannu, with outposts in Mardān and Tānk. The medical work of the mission is most beneficial, and people come from great distances to be treated by the mission doctors. The Province lies in the Anglican diocese of Lahore. It is all included in the Roman Catholic prefecture of Kashmir and Kāfiristān, excepting Dera Ismail Khān District, which lies in the diocese of Lahore.

Occupa- The majority of the people of the Province are agriculturists. tions. In $190 \mathrm{r}, 64 \frac{1}{2}$ per cent. of the population was returned as dependent on agriculture. This high percentage illustrates the backward condition of industry, only 14.2 per cent. being returned as employed in the preparation and supply of material substances, and 2.3 per cent. in commerce. The artisans are cotton-weavers $(39,000)$, leather-workers $(29,000)$, blacksmiths and carpenters $(26,000)$, and potters $(12,000)$. Other classes are mainly employed in the large cantonments.

Food. The food of the peasant has improved considerably since annexation. Two meals a day are usual, one at ro A.M., and the other, the principal meal, at 8 P.M., or earlier in winter. The early breakfast of the Punjab is seldom taken except in Hazãra, and even there consists only of food left from the previous evening. The townsfolk as a rule eat wheaten bread. In summer the well-to-do countryman consumes a mixture of 
wheat and barley cakes, vegetables, pot-herbs, wild fruit, and milk in various forms. In winter, maize and millet are the staple diet, as they are said to be more warming, but a more obvious reason is the fact that they are harvested in the autunin. In the irrigated tracts the people live better, eating khichri, a mixture of rice, pulse, and vegetables, and a kind of hot porridge. The poorer peasants, however, sell their rice and wheat, and use the cheaper millet. All Pathāns eat meat when they can afford it. The Pathān is generally abstemious, and outside the towns the use of opium and spirits is regarded as disreputable. Smoking is universal, despite the efforts of the Mullās to put a stop to it.

The dress of the peasant consists of a turban, a loose shirt Dress. or tunic, baggy trousers, tied round the waist by a running string, and two or three shawls or a Swāti blanket wrapped round the waist or placed on the head as a protection against the sun. In Waziristān the shirts or tunics worn by the men, though indescribably filthy, are often elaborately embroidered round the neck and down the back. Waistcoats are worn not uncommonly. A leather belt is always worn on a journey by those who have arms to put in it. In parts of the southern Districts among the Jats the trousers are replaced by a loincloth, and a sheet is thrown over the shoulders. Women wear an upper garment forming a bodice and skirt in one piece, dark blue in colour with a red border, and a yoke. Underneath are worn baggy trousers, and above is a shawl. Sandals of grass or leather or shoes of the ordinary Punjab type are worn by both sexes. Under Muhammadan rule a Hindu was not allowed to wear a turban, and a skull-cap is still his headdress. In winter Pathāns wear a postīn or sheep-skin coat with the wool inside. In the south the hair is generally allowed to grow long and sometimes to curl into ringlets. In Peshāwar the Pathān shaves his head. The hair of the women is elaborately braided.

A house generally consists of a single room about 25 by 12 Dwellings. feet, built of the material most easily obtainable. In Kohāt and parts of Hazāra rough stone cemented with mud is used, with coarse slate for the roof. Elsewhere the walls are made of mud mixed with straw or of grass wattles. Wooden rafters support the roof, which is of mud and flat. The internal arrangements are very simple. The grain-safe is the principal piece of furniture; and two or three beds, a low stool or two, some spindles, and baskets for wool and clothes complete the list. "Hospitality is a characteristic of the Pathān, and every 
village has its guesthouse, maintained by the headman or a few of the leading villagers. An unlimited supply of beds, blankets, and food is the mark of a true Pathān headman, and to a great extent his influence depends on his extravagance in entertaining. An ordinary guest receives bread and some condiments, but for an honoured guest a fowl and for a powerful chief a sheep or goat is killed. The guesthouse is also used as a village club where residents and visitors assemble to smoke and talk, and the bachelors of the village sleep there, as Pathān custom does not allow them to sleep at home after reaching man's estate. As elsewhere, the Muhammadans in

Disposal of dead.

Amusements. this Province bury their dead. Hindus burn them, but it is not usual to carry the ashes to the Ganges.

Most Pathāns are fond of field sports, such as hawking, hunting with dogs, and shooting. Frequently they combine with these the more exciting pleasures of highway robbery, cattle-lifting, and burglary. In parts of Kohāt a favourite pastime is to beat the low jungles at night with blazing torches, so that any hares or partridges that may be disturbed are dazzled and secured. In the north fighting rams and quails afford great amusement, and young men play a wrestling game rather like cock-fighting. Farther south tent-pegging is the national game, and on every occasion of rejoicing all who own horses assemble for the sport. In default of a wooden peg an old grass sandal will serve. Ainda, a kind of prisoner's base, is played keenly in Bannu, though not perhaps to the same extent as in the adjoining Punjab Districts. Everybody is fond of music, singing, and dancing, and the half-Gregorian style of music affected by the minstrels is not unpleasing. It is claimed for them that they distinguish intervals too subtle for the European ear to appreciate, though they know nothing of harmony, and consider European music mere noise. The recitations of the minstrels are sometimes epic in character, but love-songs and burlesques are favourite subjects also. Some of the latter are witty and do not spare British officials. Often, however, both recitation and gesture are obscene. Muhammadans picnic and feast on the two Id festivals, and Hindus celebrate the Baisākhi in April and the Dasehra in October. In Peshāwar a fair called the Jhanda Mela is held in the early spring in honour of Sakhi Sarwar, a Hindu saint, who is held in equal honour by Hindus and Muhammadans.

Names and Natives, whether Muhammadan or Hindu, have generally titles. two names, though sometimes one is considered sufficient. In common speech names are contracted; thus Fateh-ud-din 
will be Fattu to his comrades, and Fazl Ilahi will become Fazlu. Where two men in the village have the same name, the tribal name is often added, and if they also belong to the same tribe their fathers' names are added to distinguish them. A son never receives his father's name. Honorific titles are considered very important. These are of two classes: those conferred or formally recognized by Government, such as Rājā, Wazīr, Sardār, Rai Bahādur, or Rai Sāhib for Hindus, and Rājā, Nawāb, Mirzā, Mīr, Mīān, Khān Sāhib, or Khān Bahādur for Muhammadans ; and, secondly, those which have a customary validity in native society, and are therefore used as a matter of courtesy by Europeans in conversation or official communications. These include Pandit, Misra, Bhai, Bāwā, Lāla, and Sodhi (Hindus), and Arbāb, Khān, Kāzi, Maulvi, Munshi, Mirza, and Malik (Muhammadans). Khān, which literally means 'lord,' is adopted as a matter of course by every Pathān, like Mr. in English, and is suggestive of the Pathān attitude to other tribes. Two Muhammadan gentlemen in Hazāra hold the title of Rājā by licence from Government, and the whole tribe of the Gakhars put Rājā before their names. In this Province, as elsewhere, a man's name is an unmistakable indication of his religion; but there are instances of Hindu families who use the distinctively Muhammadan title of Khān, while the reverse process is exemplified in the Gakhars, who are Muhammadans to a man.

In the spiritual hierarchy titles are of even greater impor- Religious tance. Saiyid is a title given only to descendants of the Prophet. titles. Next in order is Mīann, one who is descended from a saint of old time and of more than local or tribal celebrity. Kureshis rank as Mīāns. Next come Akhundzādas or Pīrzādas, descendants of holy men having local or tribal repute. Last come the Sāhibzādas, descendants of Mullās or priests who had acquired a reputation for sanctity. Yet these religious classes need not necessarily occupy themselves with religion, and their profession or character affects their status only to a slight extent in popular esteem.

The settled Districts of the Province form two main tracts, Agriculture. which differ markedly in their agricultural conditions. The Soils and first lies east of the Indus, and consists of the sub-Himālayan general District of Hazāra, where the soil, deep and rich in the plain tural contracts, but shallow and stony in the hills, receives sufficient rainfall. Here a good spring crop is assured in the plains, except on the rare occasions when the winter rains fail; but the autumn harvest is inferior to that of the lower hills, where 
it forms the chief crop, while the higher altitudes above 5,000 feet hardly produce any harvest in the spring. The other tract, west of the Indus, may be further subdivided into stony uplands and level plains. In both tracts the rainfall, which averages less than 20 inches in the year, is uncertain in amount and uneven in distribution, and both depend largely on irrigation. The plains comprise the Peshāwar valley, the Bannu and Marwat plains of Bannu District, and that of Dera Ismail Khān ; but the soils vary greatly. A light, porous surface soil, more or less intermixed with sand and underlain by strong retentive clay, is found in Peshāwar, while a sandy gravel predominates in Bannu, and sand in the Marwat valleys. In Dera Ismail Khān, the dīman, or 'skirt of the hills' has a clayey soil, and is fringed with a strip of alluvial loam along the Indus. Wherever irrigation is applied, the rich silt deposits tend to make the soil deep and stiff, with a large admixture of clay. Cultivation depends more on facilities for irrigation than on the intrinsic fertility of the soil. The Peshāwar and Bannu valleys are well irrigated and are, therefore, highly cultivated; in Marwat, which depends mainly on the rainfall, the harvests are precarious; and in the daman the crops depend on the embankments, which hold up the surface water, or, in the riverain strip, on wells and floods from the Indus and the fertilizing floods brought down by hill torrents. In the hills the best cultivation is found in the valleys of Kohāt, which generally contain a good clean loam, singularly retentive of moisture, and therefore well able to resist drought. Elsewhere the hill soils are thin and poor, and the harvest is entirely dependent on well-timed rainfall.

Harvests. There are two harvests: the kharif or autumn, sown from May to August, and reaped between early September and the close of the year; and the rabi or spring harvest, sown from October to January and mostly reaped in April or May. Extra spring crops, chiefly tobacco, melons, \&c., are cut in June. Sugar and cotton are classed as belonging to the autumn harvest, but are on the ground for nearly a year.

The systems of cultivation vary greatly, as might be expected where conditions are so diverse. In Hazāra the main factor is the elevation, the cold mountain ranges producing little but autumn crops, while in the plains the rabi is the chief harvest. In highly irrigated tracts, whether in the plains or in the fertile valleys of Kohāt, the cultivator's main object is to make the most of the water at his disposal, and the best lands are cropped twice a year for years together. Even inferior lands 
often bear two successive crops, followed by a year's fallow; but, in the parts of Dera Ismail Khān watered by embankments, where land is very abundant, the people prefer to leave the land fallow for two years out of three.

Rotations are to some extent followed, the idea being, as Rotation in Bannu, to follow such crops as wheat, cotton, tobacco, or of crops. turmeric, which are considered exhausting, by clover, maize, barley, or some other recuperative crop the residue of which is ploughed into the soil. When the crop depends on rain, the system pursued is largely determined by the character of the soil, and-by the rainfall of each season; some lands are cropped only once every three or four years, others are cropped continuously until exhaustion compels a fallow, and one year the cultivation will be all for autumn, the next all for spring crops. Cultivation in the Indus riverain is equally variable, as it depends on the floods.

The tillage of the Province is not of a high order. This is Ploughing, due in part to the now obsolescent custom, formerly universal in all Pathān tribes, of a periodical redistribution of holdings. Further, the Pathān is notoriously lazy, and half a century of settled government has not altogether dispelled the demoralization caused by the anarchy that prevailed before annexation. In the lighter soils the seed is often sown at the first ploughing, but other soils are usually tilled from three to six times, according to the crop. The plough, drawn by cattle, resembles that used in other parts of Northern India; but a large heartshaped iron spade is often used in the heavy clay soils by the Bannuchis and in Daur, either to break up the clods before ploughing or instead of the plough. Seed is usually sown broadcast. Weeding is seldom attempted. Manure is used near villages, its use being limited only by the amount available. In Marwat, Yūsufzai, and the Khattak and Mīrānzai tracts in Kohāt, cultivators often cut the stalk close to the ear, leaving the straw to rot on the ground, while elsewhere it is utilized for fodder. Grain is trodden out by oxen, and winnowing is done by hand with fans. The agricultural implements in use are of an ancient type, but the iron sugar-mill has almost entirely replaced the old wooden press.

In I $901,1,363,000$ persons, or 64.5 per cent. of the popu-Population lation, were returned as supported by agriculture, and of these supported 4 I 8,000 , or $3^{\mathrm{I}}$ per cent., were actual workers. Of the latter, culture. 2 I6,000 were peasant proprietors, including cultivating owners or mortgagees, and r68,000 were cultivating tenants, only 28,000 being non-cultivating owners or tenants. Agricultural 
labourers numbered only 15,000 actual workers, most of the agricultural work being done by the cultivators themselves (who are often able to assist one another when harvest time falls differently in different places), and by village menials, tanners, sweepers and the like, who in addition to their proper calling obtain a great portion of their income from harvest wages paid in kind.

Wheat. Wheat is the chief crop of the spring harvest. It is sown usually in the latter half of October and November, but sowing may begin as early as the middle of September or as late as the middle of January. The harvest is gathered in May and June. Wheat ordinarily covers $\mathrm{I}, 094$ square miles, though in good years, such as $189 x, 1898$, and 1904 , it was sown in more than I,406 square miles. About one-third of the crop is irrigated. The average yield per acre is on irrigated land from $7 \frac{1}{2} \mathrm{cwt}$. to $I \frac{1}{2}$ ton, and on unirrigated land from $3 \frac{1}{2}$ cwt. to $5 \mathrm{cwt}$.

Barley. Barley is next in importance. It ordinarily occupies more than $3 \mathrm{I} 3$ square miles, though in good years, such as $189 \mathrm{r}$ and $r 898$, it covers double that area, and in a year of scarcity, like 1902 , sinks to ${ }^{5} 6$ square miles. Although sown rather later than wheat, it is the first crop to ripen in the spring, and harvesting begins as early as April. About two-fifths of the crop is usually grown in irrigated land. The yield per acre is slightly less than that of wheat.

Gram. Gram, which ordinarily covers about 188 square miles, is sown at about the same time as wheat and barley, and reaped as a rule after the latter and before the former. It is grown chiefly in Bannu, which returns nearly two-thirds of the total area covered by this crop. From 4 to $5 \mathrm{cwt}$. per acre is a good return.

Maize. Maize, the chief crop of the autumn harvest, generally covers about 625 square miles, coming next to wheat. It is sown in July or August, or occasionally as early as April, and is harvested from the middle of September to the end of November. More than half the crop is usually grown on irrigated land, Hazāra being the only District in which it is largely produced without irrigation. Peshãwar and Hazāra claim most of the out-turn, and it is practically unknown in Dera Ismail Khãn. An acre of irrigated land will give from ro to $\mathrm{r}_{4} \mathrm{cwt}$. of maize, while unirrigated land seldom produces more than 5 cwt.

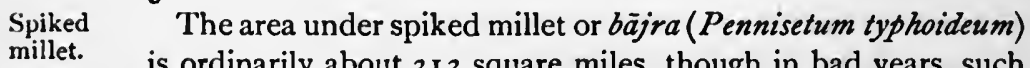
is ordinarily about $3{ }_{3} 3$ square miles, though in bad years, such as 1892 and 1900 , it is less than half as much. June and July 
are the best months for sowing, though it may be sown as early as April, and it is mostly reaped in October and November. Dera Ismail Khān and Kohăt are the chief Districts for bäjra, which is rarely irrigated. From 3 to $7 \mathrm{cwt}$. per acre, according as the land is with or without irrigation, is the usual yield of bājra and also of jowīar.

Great millet or jozvär (Sorghum vulgare) occupies usually Great about 109 square miles. In good years, such as 1891 and millet. 1893 , it rose to 156 square miles, while in 1902 , a bad year, it fell to 63. It is chiefly grown in Peshāwar, where very little spiked millet is grown. Less than a quarter of the crop is irrigated. The sowing and harvest times are the same as those for spiked millet. The crop is often grown for fodder, and is then sown very thickly and known as chari.

Rice is but little cultivated, covering only 49 square miles Rice. on an average, chiefly in Hazāra, Peshāwar, Kurram, and Tochi. It is confined to irrigated land, and yields 8 to ro cwt. per acre.

Besides gram many varieties of pulses are grown, usually Pulses. mixed with other crops. Of these the chief are $m \bar{a} s h$ (Phaseolius radiatus), mung ( $P$. mungo), and moth ( $P$. aconitifolius) in autumn, and masür (Eroum Lens) in spring. Mung and $m \bar{a} s h$ ordinarily cover $3 \mathrm{I}$ square miles, though in 1893 they were sown in about twice that area, and the other pulses occupied rog square miles.

Cotton, mostly produced in Peshāwar and Dera Ismail Cotton. Khān Districts, is sown on about 50 square miles, rising in good years, such as 1891 and 1896 , to 109 , and falling in bad years, such as 1892 and 1902 , to 3 square miles. The seeds are used as fodder.

The oil-crops chiefly grown are til (Sesamum indicum) and Oilseeds. rapeseed. They ordinarily cover about $\mathrm{I} 20$ square miles, but in good years, such as $189 \mathrm{x}$ and 1893 , the area increases to more than double.

As recently estimated, the total production of food-grains Total in an average year in the Province amounts to about 539,000 produce. tons, and the total consumption, including fodder, grain, and wastage, to $55^{2}, 000$ tons. The excess of consumption over production, however, is partly due to the large number of temporary immigrants, and men in Government service.

The total area under fruit orchards is estimated at 4,000 Fruit. acres, of which 2,700 acres are situated in Peshāwar District. The chief kinds of fruit are grapes, peaches, Orleans plums 
(alücha), quinces, pears, figs, pomegranates, water-melons, loquats, and dates. Mulberries grow wild almost everywhere. Most of the produce is consumed locally ; but dates from Dera Ismail Khān find a market in Multān and other neighbouring Districts, while apricots from Hazāra and grapes from Kohāt are sent as far as Rāwalpindi and sometimes Lahore. The only District which exports fruit in considerable quantities is Peshāwar. The system of fruit cultivation is crude, though an occasional attempt has been made to introduce improved varieties. Pomegranate is the fruit most extensively cultivated, and the Peshāwar pomegranate is now considered to be superior in quality even to that of Jalālābâd. The principal varieties of grapes are bedāna ('seedless') white and bedāna black with round berries, and husaini with long oval berries. The annual export of fresh fruits from Peshāwar is estimated in maunds at : pomegranates, 37,500 ; quinces and pears, 37,500 ; grapes, 4,500 ; peaches, 4,500 ; Orleans plums, 1,500 ; total, 85,500 maunds $(3,130$ tons). Pomegranates are sent to the whole of India and as far as Rangoon; quinces are chiefly consumed in the Punjab, while pears go to Rangoon; the export of grapes and peaches is generally limited to Northern India, a small quantity only being sent to Calcutta, as they do not keep longer than about five days; for the same reason, plums are mostly exported to the Punjab, only selected fruit being dispatched to Calcutta. A considerable portion of the fruit imported from across the frontier comes to Peshāwar; this largely consists of dried fruits (almonds, raisins, nuts and the like), but also includes musk-melons, grapes, and pomegranates. A special fruit van, booked every day from Peshāwar to Howrah during the busy months of September, October, and November, in the height of the pomegranate, quince, and pear season, carries about 5,000 maunds a month.

Loans. In but few tracts, outside the Indus valley, are conditions suitable for sinking irrigation wells; but loans are largely taken for the construction and repair of the dams, by means of which the surface water from the hills is utilized for irrigation. Advances for seed and bullocks after the monsoon rains are usually in great demand. Between $189 \mathrm{I}$ and 1900 about Rs. 19,000 was lent annually under the Land Improvement Loans Act, and the advances amounted to Rs. 10,000 in $1900-1$ and Rs. 39,6 11 in $1903-4$. The loans bear interest at $6 \frac{1}{4}$ per cent. per annum, the borrower's holding being hypothecated as security. Under the Agriculturists' Loans Act about Rs. 40,000 was advanced annually from 1891 to 1900 ; 
Rs. 50,000 was lent in r900-r and Rs. 49,347 in 1903-4. These loans are made on the borrower's personal security.

Throughout the Province the amount of agricultural indebted- Indebtedness is considerable, but in Kohāt the Pathān proprietary ness. bodies are strong enough to prevent their lands from passing to outsiders. In the other Districts there is some danger that the agricultural tribes may be expropriated, and the Punjab Land Alienation Act has been extended to them (excluding Peshãwar) in a modified form. Creditors are nearly always Hindus of the trading classes, and the rate of interest on loans may be anything from 12 per cent. upwards.

The Province possesses no noteworthy breed of cattle, Cattle. except the Peshāwar buffalo, which is used for burden and will carry to market as much as ro to 15 maunds of agricultural produce. The other local breeds are small and weak, but as there is not much well-irrigation strong cattle are not required. When needed, they are generally imported from the Punjab.

Sheep and goats are bred in every District, but large num- Sheep bers are also brought from across the border for the winter and goats. grazing. The two chief breeds of sheep are the ordinary thintailed variety of the Punjab, and the dumba or fat-tailed. Sheep and goats are kept for their wool and hair and the profits from the sale of the young, and there is a large market for mutton in the cantonments.

Camels are largely used for transport, but are not bred Camels. except in Kohāt District.

No District has any special reputation for its horses, though Horses and horse-breeding is encouraged by the supply of stallions kept by donkeys. the Imperial Remount department in Hazāra and by the District boards in the remaining Districts. The best animals are imported from beyond the border. Donkeys are much used for local transport; and the Remount department keeps donkey stallions for mule-breeding in Hazāra, where the nature of the country renders the use of mule transport indispensable.

Of the total cultivated area, 72 per cent. is dependent on Irrigation. the rainfall, 25 per cent. is irrigated by canals, 2 per cent. is irrigated by perennial streams or inundated by river floods, and less than one per cent. is irrigated by wells. The present canal systems utilize the waters of the Kābul, Swāt, and Bārā rivers in Peshāwar District, of the Kurram in the Kurram Agency and Bannu, of the Tochi in Daur and Bannu, and of the minor affluents of the Indus in the remaining Districts. The Indus itself has not as yet afforded any great supply for irrigation; but a scheme for an inundation canal on its western 
bank at Paharpur in Dera Ismail Khān District, which would command nearly 94 square miles, is under preparation.

Work will also shortly begin on a bolder project, that of bringing a canal from the Swàt river by a tunnel under the Malakand pass into the eastern portion of Peshāwar District. When completed this will supply, besides the independent villages of Sam Rānizai, from which a water-rate will be levied, an area of nearly 300 square miles in the north-eastern portion of the District, for which the existing Swăt River Canal does not suffice.

The demand for irrigation is greatest in the arid plains of Dera Ismail Khān and Bannu. In the former District there is considerable irrigation from the creeks of the Indus, and from hill torrents and perennial streams, but no large canal has been made. Bannu is in parts very highly irrigated, 30 per cent. of the cultivation in that District being protected by canals. In the Daur tract of Northern Waziristān the whole of the cultivated area is irrigated. Nearly all the cultivation in the Kurram valley is watered from the Kurram river and the snow-fed streams, which descend from the eastern slopes of the Safed Koh. In Kohāt the Kohāt Toi and perennial streams irrigate considerable areas, but the broken character of the District forbids any large schemes. Hazāra possesses an ample rainfall, and its hill tracts are to a great extent independent of canals; but its plains and open valleys receive an abundant and fertilizing irrigation from the perennial streams, the Kunhār, Siran, Dor, and Harroh. The District in which irrigation has been most fully utilized is Peshāwar. Wells are confined to the Swäbi tahsill of Peshãwar, the Indus riverain in Dera Ismail Khān, and parts of Kohāt. The physical conditions of the Province preclude any great extension of well irrigation.

Before annexation canals had been dug in Peshāwar, Bannu, Daur and elsewhere. In Peshāwar several small canals were constructed under Mughal or Durrāni rule. Most of these are still in working order, and they are included among the scheduled canals which are managed by the Deputy-Commissioner. The total area irrigated from this source is about 203 square miles, paying a net assessment of nearly 6 lakhs. The Swàt River Canal, which irrigates about $25^{\circ}$ square miles in the table-land east of the Swāt and Kābul rivers, was completed in 1885 . The KĀBUL River CANAL, which irrigates 78 square miles in the Peshāwar and Naushahra tahsils, was completed in 1893 . Both the Kābul and Swāt Canals are the property of the Government. The Bārā is a scheduled canal, 
but its weir and upper distributaries were constructed and are managed by the Irrigation department. Besides these canals, the Michni, Dilāzāk, and Shabkadar branch were constructed by the District board of Peshāwar in 1896 .

The numerous canals in the Districts south of Peshāwar are all private, none being owned by the Government, though they are to a certain extent controlled by the Deputy-Commissioners on behalf of the people, with the aid of a small establishment paid from a cess levied in the area irrigated. All these canals are perennial.

Those canals which are under departmental control are classed as 'major' works. The total outlay on them up to $1903^{-4}$ was $5^{6}$ lakhs, and the average receipts have been II per cent. on the capital outlay. Other canals are classed as 'minor' works. The total expenditure on these has been 5 lakhs, and the return II per cent. on the sum expended.

No canal revenue, beyond a small cess to cover the expenses Canal of management, is levied on the private canals, but the lands revenue. irrigated by them are assessed to land revenue at irrigated rates. Water-rates are paid on the canals owned by the Government or the Peshāwar District board, the rate usually varying according to the crop grown.

Rights in water are as valuable as rights in land, though the System of two rights are now sometimes distinct when the supply of the water diswater is very abundant. The distribution of the available water-supply is governed by ancient customs, often of great intricacy when the supply is scanty. Its ultimate distribution among individual co-sharers is usually determined by lot.

Under native rule the State took all, or nearly all, the Rents, produce of the land which was not required for the subsistence wages, and of the cultivators, in tracts where such exactions were possible, Rents. such as the Peshāwar valley and the Haripur plain in Hazāra. In outlying areas, such as the northern glens of Hazāra, the remote valleys of Kohāt, and the Bannu Marwat plain, the revenue could, however, be collected only by an annual mili. tary expedition; and, as this was not always feasible, the practice arose of farming out large tracts to the local chiefs for a cash revenue, the amount of which usually depended on the chief's strength and the expediency of conciliating him. This chief similarly took all he could from the actual cultivators. In these circumstances there was no room for a landlord intermediate between the cultivator and the state or local chief; and it is only since the value of land has risen under the milder British assessments that anything in the shape of a 
margin leviable as rent has been in any general way available for the owners of land.

The assessment on rent-paying lands, which under native rulers was usually taken direct from the cultivator in kind, is now always collected from the owner in cash, and the latter recovers from the tenant, in kind or in cash, an amount which ordinarily runs to at least three times the value of the assessment. The usual practice is to take rent in kind at a share of the produce, and produce rents are paid in 57 per cent. of the rented area of the Province; but where the crops grown are difficult to divide, and in the neighbourhood of towns, or on land held by occupancy tenants, it is not unusual to find rents paid in cash. The exact rate at which a rent in kind is paid is largely a matter of custom, and such rents, while varying considerably from soil to soil, do not change much from time to time. Cash-rents, on the other hand, have necessarily increased with the rise in the prices of agricultural produce, and the average incidence of such rents was Rs. 3-4-7 per acre in $1901-2$.

As more than 48 per cent. of the land is cultivated by the owners themselves, and a fair portion of the rest by owners who pay rent only to co-sharers, the tenant class in the NorthWest Frontier Province, as in the Punjab, is neither so large nor so distinctively marked as in the rest of Northern India, and the law affords much less elaborate protection to the tenant than is usual in the United Provinces or Bengal. A limited number of the tenant class, amounting to 22.5 per cent. of the whole, has been marked off by the legislature on certain historical grounds as entitled to rights of occupancy; and the rents of this class, if paid in cash, cannot be enhanced to a rate exceeding the land revenue by more than $12 \frac{1}{2}$ to 75 per cent. (according to circumstances). In the case of the remaining tenants who hold at will, no limit is fixed to the discretion of the landlord in the matter of enhancement; but the procedure to be followed in ejectment, and the grant of compensation for improvements legally executed, is provided for by the law in respect of both classses of tenants. Rent in kind is usually one-half the produce or more on irrigated and onethird or less on unirrigated land, the tendency being for rents to rise on the former.

Wages. With normal prices, the sum required for the food of a labouring family may be taken at about Rs. $4 \frac{1}{2}$ a month, and to this Rs. $1 \frac{1}{4}$ a month must be added for a reasonable amount of furniture, clothing, and other necessaries. The ordinary un- 
skilled labourer, therefore, requires about Rs. 6 a month, or its value, and this may be taken as the ordinary rate now prevailing. The labourer in a town is usually paid entirely in cash; in the country he is paid either wholly or partially in kind. The agricultural labourer consumes a little more food than the town labourer; but whereas the latter has house-rent to pay, the former is generally housed by his employer. The cultivator who rents but does not own land, lives at a standard of comfort very little higher than the landless labourer. As his expenditure, like his income, is almost entirely in grain, and a large part of his food and clothing is produced by himself or his family, it is difficult to estimate his receipts in money; but it would probably be correct to say that, when the ordinary day labourer of the Province receives Rs. 6 a month, the income of the cultivator after paying his rent would be represented by something like Rs. 7 or Rs. 8 , while if the cultivator were also an owner of land, his average income, after payment of Government dues, might be put at Rs. ro, or more. Skilled labourers, such as blacksmiths or masons, get about Rs. 16 a month or its equivalent, and carpenters still more. A clerk receiving between Rs. 20 and Rs. 30 has to maintain a better style of dress and living than men with the same income who work with their hands. Wages are now twice or thrice as high as they were under Sikh rule, and there has been a progressive rise in recent years. So far as the labourer's food is concerned, its money value has increased 30 to 35 per cent. since 1880 , while the other items of his expenditure have decreased in price ; and it would probably be correct to say that during the same period the labourers' wages have risen some 20 to 25 per cent. With artisans the increase has been larger, or from 25 to 30 per cent. During the decade $1891-1901$ the extension of railways, roads, and cantonments greatly increased the demand for skilled, and to a less extent for unskilled, labour. Wages in consequence have risen more than the cost of living. At harvest time labour from the Punjab and independent territory is required.

No official statistics are maintained regarding the prices of Prices. any but agricultural staples. The rise of prices is best studied in the retail figures, which are available in greater completeness than the others. The table on the next page shows rates, in seers per rupee, at the principal centres.

From these it will be seen that the rise in the price of agri- Material cultural produce has been steady and almost universal, varying condition from nearly 40 per cent. in the price of wheat, the most people. important crop, during the last twenty-three years at Dera 
Ismail Khān, to less than 5 per cent. in the case of gram at Peshāwar during the same period. The price of land has steadily risen meanwhile; and there is no reason why the agricultural population, among whom the standard of comfort has enormously improved, especially in Peshāwar, should not have their full share in the prosperity of the country, but for their inveterate propensity to improvidence and extravagance, to say nothing of litigation and crime, which has caused so much land in Peshāwar to pass into the hands of the moneylending mortgagee.

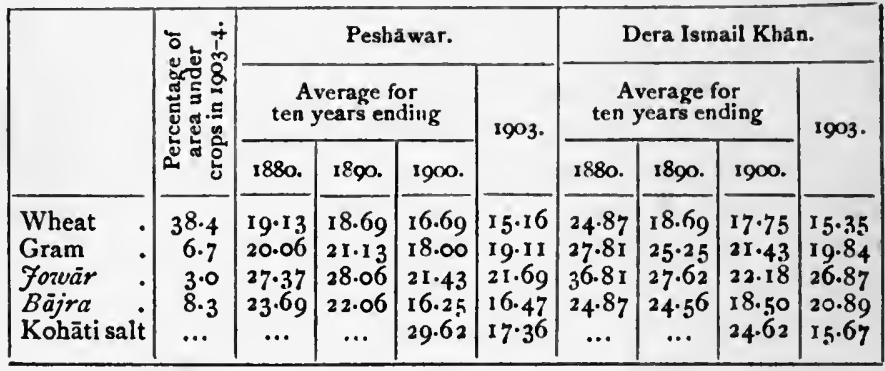

Forests.

The operations of the Forest department are confined to the 'reserved' forests in Hazāra, which have an area of 235 square miles, and that District forms the only forest division in the Province. It is in charge of a Deputy-Conservator, under the control of the Revenue Commissioner, but the Conservator of Forests, Punjab, exercises a general professional superintendence over the management of the forests. The financial results of the department are shown below :-

\begin{tabular}{|c|c|c|c|c|c|}
\hline & & $\begin{array}{l}1880-1 \text { to } \\
\text { 1889-90 } \\
\text { (average). }\end{array}$ & $\begin{array}{l}1890-1 \text { to } \\
1899-1900 \\
\text { (average). }\end{array}$ & $1900-1$ & $1903-4$ \\
\hline $\begin{array}{l}\text { Revenue } \\
\text { Expenditure }\end{array}$ & & $\begin{array}{c}\text { Rs. } \\
78,000 \\
60,000\end{array}$ & $\begin{array}{c}\text { Rs. } \\
87,000 \\
62,000\end{array}$ & $\begin{array}{c}\text { Rs. } \\
89, \infty 00 \\
53,000\end{array}$ & $\begin{array}{c}\text { Rs. } \\
83,000 \\
52,000\end{array}$ \\
\hline Surplus & - & $18, \infty 00$ & 25,000 & $3^{6,000}$ & $3^{1, \infty}$ \\
\hline
\end{tabular}

The revenue is principally derived from sales of deodār. The village forests of Hazara are also important, and the DeputyCommissioner is entrusted with their administration. Hazāra likewise contains military reserves, 8 square miles in area. In Kohāt 74 square miles of unclassed forest and Government waste are controlled by the Deputy-Commissioner, and there is a small forest area in Peshāwar in which the people have rights jointly with Government. The other two Districts 
contain a few scattered rakhs, but these consist chiefly of scrub and form grazing-grounds rather than forests. The chief trees in the Hazāra forests are deodār, Pinus excelsa, blue pine, Scotch fir, wild.cherry, ilex, sycamore, horse-chestnut, walnut, and yew; while in the other Districts the shisham (Dalbergia Sissoo), mulberry, willow, Melia sempervirens, Acacia modesta, tamarisk, olive, and poplar are most common. The dwarf-palm grows largely in the lower hills, and is much used for making mats and other articles. Beyond the administrative border the Waziristān hills contain some fine forests, as do the upper slopes of the Safed Koh in Kurram, and the highest ranges in Chitrāl. All these forests, however, are as yet almost unexplored.

The only mineral product of commercial importance in the Mines and Province is rock-salt, which is obtained from the Jatta, Mālgīn, minerals. Bahādur Khel, and Karak quarries in Kohāt District. The average output during the six years ending 1903 was 2,640 tons. Saltpetre is manufactured in most Districts from the nitrous earth found on village sites. In 1903-4 there were three refineries in the Province, which produced about 150 tons of refined saltpetre and $25 \mathrm{cwt}$. of impure salt (sitta).

Associated with the Kohāt salt are layers of gypsum and Other alum shale, but they are at present of no commercial impor- minerals. tance. Marble is worked in Peshāwar District near Naushahra and opposite Attock. Limestone and sandstone are abundant, and are locally used for building. There are petroleum springs at Panoba in Kohāt, and in one or two other places in the Province, but the amount of oil yielded is insignificant. Under Sikh rule, sulphur was worked near Nakband in Kohāt District, but the pits are now closed. It is also found with gypsum in the Sulaimann range. Gold occurs in minute quantities in the sands of the Indus and Kābul rivers. Traces of lignite have been observed in Hazāra and in the Sheikh Budin range, and probably exist in other parts of the Province. The lignite in Hazāra is regularly worked and made into briquettes for local use, but the out-turn does not exceed r,055 cwt. annually. Coal of a fairly good description has also been recently found, in considerable quantities, along the eastern border of Bannu and Kohāt Districts in the Maidān range which separates them from the Punjab District of Miānwāli. Iron is found in the Yüsufzai hills, where there are signs of old workings, and workings still exist in Wazīristān. Red hematite ore is also found at Bakot in Hazāra District. From Bājaur fused or hammered iron of good quality is imported into Peshāwar. 
The metal is said to be abundant at Baroul in Dir, but is no longer worked. Antimony has been found with iron at Bakot, and a very good ore is also imported from Bajaur. The Mehtar of Chitrāl has derived a considerable income in recent years from the sale of orpiment, but the mine now shows signs of exhaustion.

Arts and Coarse cotton fabrics are woven by hand in every part of manu-

factures.

Cotton.

Afiidi A very interesting production of Peshāwar is a cotton fabric waxcloth. decorated with a substance called roghan, a preparation of oil obtained from the wild safflower (Carthamus oxyacantha), by the Afrìdis, whence the material is generally known as Afridi waxcloth. The roghan is applied in a plastic condition to the fabric by means of an iron style on the lines of the required pattern. It is then pressed into the cloth with the moistened tip of the finger, when it sets and firmly adheres to the texture. Various colours are used, and the composition is often dusted over before drying with powdered mica, thus giving the pattern a silvery gloss.

Wool. Peshāwar and Dera Ismail Khān produce wool of fair quality, but the only woollen goods woven are blankets, the best of which are made in Swăt for export. Woollen camel-bags are also woven. Felted namdäs are used as coverings for animals, for keeping ice, and for saddle-pads, the better qualities having coloured designs inserted. Hazāra and Kohāt export namdās on a large scale, the largest serving as carpets. Among the Wazirs on the Bannu border a kind of woollen dari is made, with a bold design and some artistic merit. The Marwats of Bannu District also make woollen-pile rugs, locally known as nakhais.

Silk. Silk-spinning and weaving are fairly important industries at Kohāt and Peshāwar, where silk turbans (lungis) are woven, and a few other silk fabrics are made in the latter city. At both places, turbans are more commonly made of fine cotton, ornamented with stripes and bars of silk and gold thread. The Kohāt lungi is richly ornamented with coloured silk bars and stripes at the ends, something like the familiar Algerian stripes. The pattern is known as the Bangash lungi, and, like the check of a Scottish tartan, is distinctive of a particular khel or clan. 
The stitch peculiar to frontier embroideries is that known as Emherring-bone, and is the most characteristic feature of the broidery. indigenous embroideries of India. In every District wraps, known as phülkāris, are embroidered with silk, those of Hazāra being of special excellence. White drawn embroidery (chikan doz) is made in Peshāwar, and some of the patterns worked on fine muslin are of exquisite fineness and beauty. It is chiefly applied to the veils (burkas) worn by Muhammadan ladies, and to quilts or soznis.

The ornaments worn on the frontier are few and simple, Jewellery. and differ little from those in other parts of Northern India. At Peshāwar massive necklets of characteristic patterns, and bangles forming a single curved roll with open-work perforations, are made. In Hazāra silver is wrought into necklaces and other articles, plates are cut out in the form of a cartouche, made convex and roughly embossed and engraved, the ground being filled in with imitation enamel in green and red. Personal ornaments are sometimes crudely enamelled in blue and yellow, while occasionally the pattern is emphasized by being roughly gilt.

Before the introduction of British rule, swords and match-Iron-work. locks were made in almost every part of the frontier, and Peshāwar still produces sword-blades and knives, while the manufacture of firearms, once an important industry, now flourishes in the Kohāt Pass.

Copper-ware, tinned for Muhammadan domestic use, is one Brass and of the specialities of Peshāwar. It is all hammered work, the copperpatterns being engraved and often loaded with lac. Trays, dishes, ewers with basins, and wine-bowls are the usual objects; and the workmen, unlike those of Kashmir who work in the same style, have not attempted adaptations to European uses. The Persian character and feeling of the ornament is much more striking than in Kashmir work, the chasing is simpler and bolder, and the forms are often identical with Persian originals, which in their turn were copied from Tãtār vessels. Very little brass-ware is made, its use being mainly confined to Hindus, who are not numerous in the Province.

At Peshāwar glazed earthenware or faïence is manufactured Pottery. for native use. The reddish earth body or paste is coated with a dressing of white earth, forming the slip or engobe. It is then dipped into a glaze, of which the basis is lead oxide. Rude patterns in manganese are outlined on the unburnt glaze, and filled in with oxide of copper, the result being green leaves, outlined in brown, on a dirty greenish white. Besides 
glazed ware, earthen vessels decorated with fleeting watercoloured painting or in coarsely pencilled parti-coloured patterns, and glass phials and bottles are made at Peshāwar. Hazāra and Bannu produce a very good quality of unglazed earthenware.

Woodwork.

Boats are built in some numbers in Peshāwar District; and the carpentry of the city is above the average, a speciality being pinjra, a kind of lattice-work, in walnut and other woods, in which the tracery consists of small laths, arranged in geometrical patterns with their edges displayed. The charm of this work lies in the fact that each small piece is fitted to the other by means of a minute joint, no glue being used. The lac turnery, carried on at Dera Ismail Khān, is of considerable artistic merit, and is applied to larger articles than is usual in this class of work, the small round tables being; well-known. The general tone of colour is subdued and almost sombre, red, black, and dark green, relieved by a little grey, being the principal colours, with ornaments in amalgam, which have the effect of dull silvery lines. The pattern is always inscribed with a style, and in certain parts the lines are filled with amalgam. Ivory and camel-bone ornaments in the shape of knobs, studs, and flowers are liberally employed. The lac-ware of Bannu is bolder in design, and of some merit, though in technique it is inferior to that of Dera Ismail Khān. The chärpais or beds of the Wazirs are so contrived that they can be used as chairs in the daytime.

Leather- The tanners of the frontier make richly embroidered leathern work. belts, with powder flasks, bullet cases, flint and steel pouches, and other accoutrements attached. They also make sheepskin coats or postins (inferior to those imported), water-bottles, mule trunks, and a certain amount of saddlery. The shoes have a great reputation, and articles in embossed leather are produced at the same place.

Factories. Organized industries are still in their infancy; and the only factories are one at Peshāwar for ginning and cleaning cotton, and ice factories at Bannu and Kohāt.

Conmerce and trade.

Trade routes.

The Frontier Province, with a territory for the most part sparsely inhabited, and without manufactures or a considerable surplus of agricultural products, owes its commercial importance to the fact that it lies across the great trade-routes which connect trans-border tribal territories and the marts of Afghānistān and Central Asia with India. These routes are determined mainly by geographical and, to some extent by political, con. ditions. The imports from Buner and Bājaur come through 
Naushahra. Most of this traffic still comes over the Malakand Pass, but the pacification of the country is leading to a more general use of the shorter routes, via the Shāhkot and Murād passes and the Totai road. Commerce with Tìrāh passes through Peshāwar and Kohat. The trade of Afghānistān comes down wholly through those two Districts and the Tochi and Gomal valleys. The bulk of it is carried on with Peshãwar by the Khyber Pass, which is open for traffic two days a week under the protection of the Khyber Rifles. Some of the trade also crosses the Peiwar Kotal into the Kurram valley and thence down to Kohāt. Next in importance is the Gomal route, which has been steadily increasing in popularity since the pacification which followed the Mahsüd blockade of 190I-2. The Chuhar Khel Dhāna and Vihowa Kharr routes, once important, are being abandoned by the nomad tribes of Afghānistān for the more developed route by rail through Baluchistān, and now only supply local needs in the country east of Kalatt-i-Ghilzai and Ghazni. The trade is borne on camels which travel in caravans ; and the owners, the Powindas, or nomad merchants, generally pass through the Province, without breaking bulk, to Lahore, Amritsar, and Multān, or, if they can afford the journey, to Calcutta and Bombay. Peshāwar city carries on a considerable trade with Afghānistān, but is too remote from the lower provinces of India to form an entrepot for the Central Asian trade, and an attempt made in r869 to establish a fair there failed. The trade with Bokhāra, once important and lucrative, has steadily declined under the double system of transit and customs dues levied by the Amir of Afghānistān and the Russians, who have included Bokhāra in their customs system. Such of the trade as still survives is being diverted to the Batoum-Bombay sea route.

The trade which is carried along these routes is registered at convenient places near the entrances to the passes traversed by the caravans.

From Buner are imported sheep, goats, grain, pulses, hides Imports and skins, and $g h i$. From Bājaur come similar products, with from across cordage and mats, oils, timber, and wool. From Tîrāh are border. imported cordage, ropes, raw fibre, fruit, vegetables and nuts, hides and skins, leather, mats, and timber. The imports from Käbul are chiefly sheep and goats, fruit, nuts and vegetables, wheat, asafoetida and other drugs, hides and skins, mats, ghi, timber, silk, and wool. The trade has-greatly increased since 1901, when the severe restrictions imposed on it by the late Amīr, Abdur Rahmān, were partially removed. 
Exports across the border.

Trade with other Provinces and States of India.

The chief exports across the border are cotton piece-goods; twist and yarn, salt, sugar, tea, tobacco, hardware, metals, leather, dyeing materials, silver, and coin.

Statistics of the trans-border trade are given in the table on page 87. It will be observed that in $1903-4$ the value of exports exceeded that of imports by Rs. 44, 1 2,000, and that the excess of treasure exported amounted to Rs. 2,64,000.

The value in $1903-4$ of the trade carried on with the principal territories, as far as this is registered, is shown below, in thousands of rupees. The trade with Kābul includes that with Central Asia; and that with Bājaur includes the large and increasing commerce with Swāt, Chitrāl, and the countries east of the Hindu Kush.

\begin{tabular}{|c|c|c|c|c|}
\hline & $\begin{array}{c}\text { Afghăni- } \\
\text { stãn. }\end{array}$ & Tìrah. & Bajaur. & Buner. \\
\hline $\begin{array}{l}\text { Imports from } \\
\text { Exports to }\end{array}$ & $\begin{array}{l}29,84 \\
5^{1,48}\end{array}$ & $\begin{array}{l}3,96 \\
4,7^{2}\end{array}$ & $\begin{array}{l}33,18 \\
55,91\end{array}$ & $\begin{array}{l}1,97 \\
3,61\end{array}$ \\
\hline
\end{tabular}

The table on p. 86 shows the rail-borne trade with other Provinces and States in India, and that with Kashmir, which is entirely by road through Hazāra District. Cotton piece-goods, metals, tea, and woollen goods are the principal imports; hides, skins, apparel (chiefly furs), and tobacco are the principal exports. The general conditions of the trade with Kashmir resemble those of the trans-border trade, in that there is a considerable excess of exports. $G h \bar{i}$ is the chief import and piecegoods are the main export. Statistics of the goods carried down the Indus are not available.

Mears of The Province is traversed by the North-Western Railway communi- system of the Punjab, which gives communication at three cation. Railways. points. The Attock bridge conducts the main line over the Indus to Peshāwar, $\mathbf{1}, 520$ miles from Calcutta, and a broadgauge extension, 12 miles in length, runs to Fort Jamrūd at the mouth of the Khyber Pass. From Naushahra cantonment a narrow-gauge branch runs via Mardān to Dargai at the foot of the Malakand Pass. The second point of connexion is at Khushālgarh, also on the Indus, 53 miles south of Attock. Here the river is crossed by a bridge of boats, which forms a link between the Māri-Attock branch of the North-Western Railway and the narrow-gauge line to Kohät and Thal ; but a railway bridge is now being built across the Indus, and on its completion the Khushālgarh-Kohāt-Thal line will be converted to the broad-gauge. Farther south there is no railway in the Province, but Dera Ismail Khān is connected with Daryā 
Khān on the Sind-Sāgar branch of the North-Western Railway by a bridge of boats during the cold season. The only line open in $\mathbf{r} 89 \mathrm{r}$ was that from the Attock bridge to Peshāwar, 44 miles in length. In 1904 the total length of railways open was 188 miles.

The railway system is supplemented by several important Roads. roads. The grand trunk road runs beside the railway from Attock to Peshāwar, and thence through the Khyber to Landi Kotal. A metalled road, 234 miles long, passes from Peshāwar, through Kohāt and Bannu, to Dera Ismail Khān, traversing the whole length of the Province. A similar road connects Khushālgarh with Kohāt and Thal, a distance of 96 miles. From Thal a partially metalled road runs up the Kurram valley to Pārachinār ( 57 miles), whence a trade route leads over the Peiwar and Shutargardan Passes to Kăbul. The roads from Bannu to Datta Khel up the Tochi valley (64 miles), and from Dera Ismail Khān to Murtazā via Tānk ( 60 miles), are also metalled. The latter is being extended to Wāna ( 57 miles), which lies a little north of the Gomal. The cis-Indus District of Hazāra is entered by a road (metalled) from Hassan Abdāl on the North-Western Railway in the Attock District of the Punjab to Abbottābãd (44 miles), whence it runs through Garh Habibullah to Domel in Kashmîr.

All the metalled roads thus lie in the settled Districts, or in the administered parts of trans-border territories, and are entirely a creation of British rule. In $1890-r$ the total length was only 294 miles, but in 1900-I it had risen to 448 and in 1904 to 524 miles. Apart from these, and excluding the metalled roads within cantonment and municipal limits, the Province possessed, in 1900-I, 4,208 miles of unmetalled road; but these are often mere camel tracks, with bridges of boats over the deeper streams in the hot season. Roads are maintained from Imperial revenues, municipal, cantonment, and District funds.

Mail tongas ply between Hassan Abdāl and Abbottābād; Means of Peshāwar and Kohāt ; Thal and Pārachinār ; Kohāt and Bannu, conveyand thence to both Datta Khel and to Dera Ismail Khān; and from the last place to Tānk and Murtazā. Cherāt and Sheikh Budin also enjoy a tonga service in summer time. Bullockcarts, ekkas, and light two-wheeled traps are used on the metalled and on some of the better unmetalled roads; but the great mass of the traffic is carried on pack-animals, camels being mainly employed, though buffaloes and donkeys are also used. 
Kivers. The navigable rivers of the Province are the Indus, Swāt, and Kanbul. The bulk of the traffic is on the Indus, on which there is a regular trade down-stream to Multān and Sind, the boats being generally broken up or sold at the end of their voyage to save the expense of towing them up-stream. As has been said, the Indus is crossed by the Attock bridge and at Khushālgarh and Dera Ismail Khān by bridges of boats. At the latter place a steam ferry replaces the bridge in the hot season. Passengers have often to wade up to their necks through subsidiary channels to reach the steamer, which only plies across the main channel. Elsewhere the ordinary country ferry-boat is used, or the rivers are crossed by means of inflated skins, the possession of which without a licence is prohibited by law, owing to the facilities they afford to criminals.

Post The territories under the administration of the Chief ComOffice. missioner of the North-West Frontier Province form a part of the postal circle in charge of the Postmaster-General, Punjab and North-West Frontier Province. There are only two postal divisions in the Province, which is included with Kashmir in a single telegraph division. The figures below show the postal business of the Province in 1903-4:-

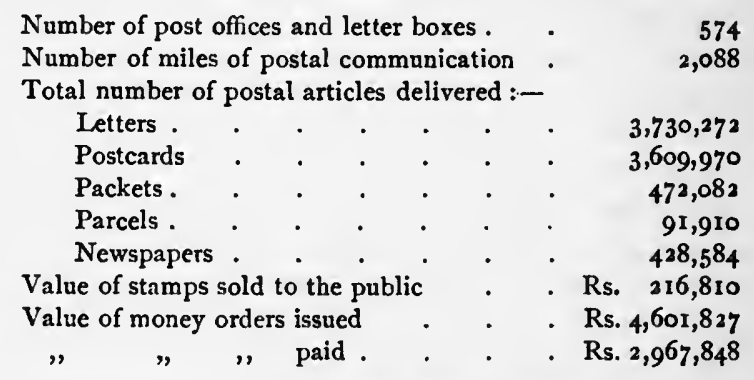

Famine. Though parts of the Province are liable to drought and occasional scarcity, famine conditions have never been recorded in any part of it. Most of the cultivated area enjoys good rainfall or irrigation, or both. The pressure of the population on the soil is comparatively light; the people are enterprising and usually have other resources besides agriculture. These include service in the army, the local militia corps, the civil and border military police, employment by railway and steamship companies as navvies and stokers, and trade, especially in Kohāt salt, and in forest produce in Hazāra.

In Hazāra the holdings are, generally speaking, fairly large ; and the rainfall is so copious that during the last twenty years there has never been any serious failure of the crops, except in 
one or two isolated tracts. Peshāwar District as a whole is practically secure from drought, except in part of the Peshãwar tahsil, where the holdings are comparatively small, and the irrigation from the Bāra river somewhat precarious, and in parts of the Naushahra and Mardān tahsills, where cultivation is wholly dependent on the rainfall; but even in the insecure parts of these two tahsils the people trade in wool and salt, and are not wholly dependent on cultivation. In Bannu a considerable portion of the cultivated area is irrigated and secure; and though the people of the unirrigated tracts are sometimes compelled to tide over a season of scarcity by migrating with their cattle to more favoured parts of their own or neighbouring Districts, the average rainfall though small is sufficient for the light but fertile soil, the surplus of one good harvest covers the deficiencies of many, and a succession of bad harvests is seldom experienced. In Kohāt the rainfall is fairly constant, part of the area is irrigated and practically secure, and the salt-mines and forests in the barren tracts provide those who are most liable to feel the pinch of scarcity with the means of earning a livelihood as carriers of salt and wood. In Dera Ismail Khann the rainfall is scanty and capricious; but the Indus valley is never actually confronted with scarcity, and the people in the damman tract, whose revenue is in ordinary years trifling as compared with the crop harvested, migrate in seasons of scarcity to the Indus valley, and when seasonable rain falls return to their own villages and recoup themselves by butmper crops. Many of these tribes, being of Powinda origin, are also able to eke out a livelihood by trading down country. The whole of the Province is thus fairly secure from famine, and no relief is usually necessary beyond suspensions and remissions of land revenue.

The North-West Frontier Province comprises both British AdminisDistricts and also the tribal areas under the political control of tration. the British Government which stretch northward and westward towards Afghānistān. In rgor it was constituted a separate administration, and placed under the control of a Chief Commissioner, who is also, in the political areas, Agent to the Governor-General of India. Lieutenant-Colonel Sir H. A. Deane was appointed to this office, which he still holds. His staff consists of members of the Indian Civil Service, military officers of the Political department of the Government of India and the Punjab Commission, members of the Provincial and Subordinate Civil Services, Police officers, and officers specially recruited for the departments requiring special know- 
ledge. The direct administrative functions of government are performed by the Chief Commissioner through a Revenue Commissioner (who is also Revenue and Financial Secretary to the Chief Commissioner, Director of Land Records and Agriculture, Commissioner of Excise, Superintendent of Stamps, Registrar-General, Inspector-General of Registration and Registrar of Joint-Stock Companies, and as regards Courts of Wards also fulfils the functions of the Financial Commissioner and Commissioner in the Punjab), a Secretary, an Assistant Secretary, a Staff officer for militia and border military police, and a Personal Assistant. The following are the heads of departments: the Administrative Medical Officer (also in charge of jails and sanitation); the Inspector-General of Education and Archaeological Surveyor; and the InspectorGeneral of Police. The Officer commanding Royal Engineers is head of the Public Works department, but the canals in Peshāwar District are under the Irrigation department of the Punjab. The Accountant-General of the Punjab exercises control over the finances of the Province.

Administrative divisions.
The British territory in the Province is divided into five Districts, of which the largest, Dera Ismail Khān, has an area of $3,40 x$ square miles, and the smallest, Bannu, $x, 676$ square miles. Particulars regarding each District will be found in the table on p. 84 .

Each District is under a Deputy-Commissioner, and is divided into sub-collectorates, called tahsils, from 2 to 5 in number. A tahsil is in charge of a tahsildär, who is invested with criminal, civil, and revenue powers, and is assisted by a naib-tahsildār, who exercises only criminal and revenue powers. Subordinate to each tahsildār are 2 or 3 field känungos or revenue officials, each of whom supervises from 13 to 19 patwäris or accountants. A patwäri maintains the revenue records of 4 or 5 villages. Every village has one or more village headmen who collect the revenue, and chaukidârs or village watchmen. Yūsufzai, Mardān, and the Naushahra tahsīl in Peshāwar, and the tahsīls of Thal in Kohāt and Tānk in Dera Ismail Khān, form subdivisions, each in charge of an Assistant or Extra Assistant Commissioner. Peshāwar city is also in charge of a subdivisional officer. The District is the unit for police, medical, and educational administration; and the ordinary staff of each includes a District Superintendent of police, a Civil Surgeon, who is also Superintendent of the District jail, and a District Inspector of schools. The Province forms a single educational 
circle, and only possesses one forest division, that of Hazāra, which comprises the District of that name and is in charge of a Deputy-Conservator under the Revenue Commissioner. There are four divisions of the Roads and Buildings branch of the Public Works department, each under an Executive Engineer, and one division (Peshāwar) of the Irrigation branch in charge of an Executive Engineer, who is subordinate to the Superintending Engineer, Jhelum Circle, Punjab, and under the control of the Chief Engineer, Irrigation branch, Punjab.

The territories lying north and west of the British Districts Political are divided into five Political Agencies-Dīr, Swāt, and Chit- Agencies, rāl; the Khyber; the Kurram; and Northern and Southern Wazīistān-each under a Political Agent. The principal Frontier frontier chieftainship under the political control of the Agent chieftainto the Governor-General in the North-West Frontier Province ships.

is Chitrāl, which is included in the Dīr, Swāt, and Chitrāl Agency. Other chieftainships in this Agency are the Khānates of Dīr and Nawagai (comprising most of Bãjaur). Both of these are divided into numerous minor Khānates, held on a kind of feudal tenure by relatives of the chief Khāns. The title of Nawāb has recently been conferred on the Khān of Dir. In the remaining tribal territories nothing approaching an organized state can be said to exist.

Under the North-West Frontier Province Law and Justice Legislation Regulation of I $90 \mathrm{I}$, custom governs all questions regarding and justice. succession, betrothal, marriage, divorce, the separate property law. of women, dower, wills, gifts, partitions, family relations such as adoption and guardianship, and religious usages and institutions, provided that the custom be not contrary to justice, equity, or good conscience. In these matters the Muhammadan or Hindu law is applied only in the absence of special custom.

The Legislative Council created for the Punjab in 1897 Legislahad jurisdiction over the British Districts of the North-West tion. Frontier Province, until by the constitution of the latter as a separate administration in $190 \mathrm{r}$ its jurisdiction was withdrawn, and the Province now has no Council. The following are the chief legislative measures affecting the Province which have been passed since 1880 :-

Acts of the Governor-General in (Legislative) Council.

The District Boards Act, XX of 1883 .

The Punjab Municipal Acts, XIII of 1884 and XX of 1891 .

The Punjab Tenancy and Land Revenue Acts, XVI and XVII of r889.

The Punjab Land Alienation Act, XIII of 1900 , as modified by Regula. tion I of 1904 . 


\section{Regulations of the Governor-General in (Executive) Council.}

The Frontier Crimes Regulation, III of 1901.

The Frontier Murderous Ontrages Regulation, IV of r gor.

The North-West Frontier Province Law and Justice Regulation, VII of 1901, which embodies certain provisions of the Punjab Courts Act, XVIII of 1884 (as amended by Acts XIII of I 888, XIX of 1895 , and XXV of 1899 ).

\section{Acts of the Punjab Legislative Council.}

The Punjab Limitation Act, I of 1900.

The Punjab Municipal Amendment Act, III of 1900.

The Punjab Riverain Boundaries Act, I of 1899 .

The Punjab Descent of Fägirs Act, IV of 1900.

Adminis- The administration of justice in the British Districts was tration of not affected by their transfer from the Punjab, except that the justice. supreme court in both civil and criminal matters is now that of the Judicial Commissioner, which has taken the place of the Chief Court of the Punjab. Subordinate to him are the two Divisional and Sessions Judges of Peshāwar and the Derajāt. As Divisional Judges these officers decide most of the appeals in civil suits from the courts of first instance. As Sessions Judges they try sessions cases, with the aid of assessors, and hear criminal appeals. Thus the Divisional and Sessions Judges in this Province fulfil the functions of District and Civil Sessions Judges in the Regulation Provinces. Appeals in courts. minor civil suits from the Munsifs' courts are heard by the District Judge, whose court is also the principal court of original civil jurisdiction in the District. The Divisional and District Courts are established under Regulation VII of rgor, which also provides for the appointment of Subordinate Judges (exercising unlimited civil jurisdiction) and Munsifs. The latter are of three grades, the jurisdiction of a first-grade Munsif being linited to suits not exceeding Rs. 1,000 in value. Two Munsifs are also invested with the powers of a Small Cause Court, under Act IX of 1887 .

Criminal The criminal courts are those established under the Code of courts. Criminal Procedure. The Deputy-Commissioner is ex-officio District-Magistrate, and as such is ordinarily empowered to try all offences not punishable with death, and to inflict sentences of seven years' imprisonment. Additional District and subdivisional magistrates are usually invested with these powers. Assistant and Extra Assistant Commissioners are, when qualified, appointed magistrates of the first class. Tahsildärs generally have second and naib-tahsildars third-class powers. Honorary magistrates, sitting singly or as benches, also exercise first or second, but more commonly third-class magisterial 
powers in Districts or smaller local jurisdictions. In all Districts an offender may be tried by a council of elders under the Frontier Crimes Regulation, and the Deputy-Commissioner may pass any sentence of imprisonment not exceeding fourteen years in accordance with the findings of the council. Sentences exceeding seven years require the confirmation of the Chief Commissioner, who has also revisional jurisdiction in all cases under the Frontier Crimes Regulation.

The revenue courts established under the Punjab Tenancy Revenue Act are those of the Revenue Commissioner, Collector courts. (Deputy-Commissioner), and Assistant Collectors of the first and second grades. These courts decide all suits regarding tenant-right, rents, and divers cognate matters in which the civil courts have no jurisdiction. Appeals from the Assistant Collectors ordinarily lie to the Collector, and from him to the Revenue Commissioner with certain linitations.

As regards the territories beyond the border, with certain Transmodifications, the provisions of the Indian Penal and Criminal border Procedure Codes, and of the Frontier Crimes and Murderous Outrages Regulations, have been extended to the administered portions of the Political Agencies of Dîr, Swāt, and Chitrāl, the Khyber, the Kurram, Northern and Southern Wazinistān, and also to the Shirāni country under the provisions of the Foreign Jurisdiction and Extradition Act. The Political Agents in Northern and Southern Wazīristān and the Kurram exercise all the powers of a District Magistrate and Court of Session in respect of offences punishable under the Indian Penal Code, the functions of a High Court as regards appeal, reference, and revision being exercised by the Judicial Commissioner.

The Registration agency is chiefly official. All Deputy-RegistraCommissioners are registrars and all tahsillärs are sub-tion. registrars under the Act; but there are also five non-official sub-registrars, who are remunerated by a percentage on the fees collected. In 1903 the Province had 28 registering officers and 9,996 documents were registered. General control over registration is exercised by the Revenue Commissioner.

The revenue and expenditure of the North-West Frontier Finance. Province are wholly Imperial, and separate figures for its finances are only available since 1902-3 (see the table on p. 88). Speaking generally, the receipts from irrigation have largely increased within the past few years in Peshāwar, the only District in which they are separated from the land revenue 
receipts. The land revenue was below the average in $1902-3$, a year unfavourable for agriculture. The receipts under this head will be enhanced on the completion of the reassessments now in progress in several Districts. Other heads of receipt show a steady tendency to increase. The expenditure of the new Province, with its growing requirements, also tends to rise. The large excess of expenditure over income is due to the geographical position and political importance of the Province, considerations of imperial policy calling for special outlay under Political (which includes subsidies to tribes, maintenance of frontier militias and tribal levies), police, general administration, and civil public works.

Land revenue. Tenures.

The character of the land tenures in the settled Districts of the North-West Frontier Province generally resembles those of the Punjab, and only such as present peculiar local features will be here described. Among the Pathāns, who own the largest amount of land in the Province, the original occupation of the land may be described as a tribal tenure, a tribe holding a tract of land which was divided into tappas or lots each held by a main subdivision of the tribe; these lots were again divided into blocks, each held by a section (khel) of the subdivision; these blocks were yet again divided into 'sides' (kandi or taraf), held by sub-sections of the khel, generally branches of what was originally a single family; and finally each kandi was subdivided into shares (bakhra), each held by an individual proprietor. The bakhra did not, however, form a single compact plot of land, for, to ensure equality, every kandi was divided into wands according to the nature of the soil and the facilities for irrigation, and a bakhra comprised one or more fields in each wand. These fields usually ran the whole length of the zvand, and as population increased the fields became so narrow that their cultivation was difficult. This, combined with the development of well and canal cultivation, has forced the people to abandon the old system of division, and the old practice of a periodical redistribution of holdings (vesh).

Redistribution of land.

A characteristic of the Pathān tenure was the periodical redistribution (vesh) of the land among not only the individual members of a section, but even among the various sections of the tribes as a whole. This redistribution was made by lot, if the majority desired it. The shares on which the original partition was made were in some cases maintained, but in others every male and in others again every male and female of the tribe received an equal share. The last method was 
followed in a remarkably complete form in the Marwat (Bannu District) and Tānk (Dera Ismail Khān) tahsìls, in which a khulla or 'mouth' vesh was made, every man, woman, and child receiving a share. The period for which a vesh was made was rarely less than five or more than fifteen or twenty years. Even as late as 1904 a redistribution of two large estates in Marwat, based on the existing number of 'mouths,' was allowed, but in many other cases it was held that the custom had become obsolete. The system prevailed more or less in every District except Hazāra, and among every tribe save the Wazirs. " Traces of it still linger in Upper Mīrānzai (Kohāt District) and Yūsufzai (Peshāwar); but they are rapidly disappearing, and the tribal shares are now only maintained as a basis for the distribution of water for irrigation, or for the partition of land still held in common. In the unadministered territories, however, the system survives. For example in Buner, and among the Isazai clans, the land and houses held by each clan are still divided among the adult males. In Swät the vesh, which originally extended to the whole valley, so that a tribesman had to change land, house, and village periodically, is now limited to the village and the land within its limits.

The method and standard of assessments in the British SettleDistricts of the Province are the same as in the PunJaB, but in ment. some, for political reasons, the assessments are lighter. Thus in Peshāwar the demand is only $5^{2}$ per cent. of the estimated half 'net assets.' In Dera Ismail Khān the recent settlement fixed a demand of $7 \mathrm{r}$ per cent., and in Kohāt from 70 to 75 per cent., of half 'net assets.' In Hazāra and Bannu Districts, now under re-assessment, the term of the old settlements was thirty years, and the existing demand is extremely light. The term is twenty years in Peshāwar, and that period has been fixed provisionally for the latest revisions in Kohāt and Dera Ismail Khān. As a rule, the demand is fixed for the term of settlement; but owing to the uncertainty of the seasons and the precarious returns from cultivation, fluctuating assessments have been introduced in parts of Dera Ismail Khān, and it is proposed to extend the system to Marwat (Bannu). Elsewhere fixed cash assessments work satisfactorily.

Of the Agencies only Kurram and the Tochi valley (Northern Waziristān) pay land revenue to the British Government. The former was summarily assessed in 1894 for a period of ten years, and is now being reassessed. On the occupation of the Tochi valley in 1895 the Daurs undertook to 
pay Government a tithe of the gross produce, and pending a settlement this was commuted into an annual payment of Rs. 8,000 in cash. A regular settlement has now resulted in a demand of Rs. 3,600. Aliena- The Punjab Alienation of Land Act (XIII of 1900) has been extended to Hazāra, Dera Ismail Khān, and Bannu ; but it is not proposed to apply it to the purely Pathān Districts of Peshāwar and Kohāt, in which the feeling of personal and individual ownership is strong, and interference with freedom of transfer would be resented. In independent territory absolute free trade in land has been the rule from time immemorial.

Miscella- Salt is obtained from the Kohāt salt quarries. Under Sikh neous revenue. Salt. rule these were farmed to local chiefs. At annexation light duties were imposed, allowances being made to the Khan of Teri and other chiefs to secure their co-operation in the new arrangements, and a preventive line was established on the Indus to prevent the export of Kohāt salt to the Cis-Indus territory. In 1883 the duty was raised to 8 annas per local maund ( $102 \frac{1}{2} \frac{7}{8} \mathrm{lb}$.). In 1896 the duty was increased to Rs. 2 per local maind, and the preventive line was withdrawn, but the prohibition against the export of this salt to Cis-Indus territory was maintained. The management of the quarries, which was formerly in the hands of the Punjab Government, was transferred to the Northern India Salt Revenue department in 1899. The Deputy-Commissioner of Kohāt District is ex officio Deputy-Commissioner of Salt Revenue.

Kohāt salt is greyish to black in colour, but of good quality, chemical analysis showing that it possesses from 87 to 94 per cent. of chloride of sodium. Traders purchase the salt they require direct from the miners under the supervision of the officers of the Salt department. Since 1903 the duty has been Rs. I-8 per maund of $82 \mathrm{lb}$. The quarries are at Jatta, Mālgīn, Bahādur Khel, and Kharak. A little Cis-Indus rocksalt is imported, but practically all the salt consumed in the Province is obtained from the local source. About half the salt produced in the Kohāt quarries is exported to Afghānistān, Tīrāh, Buner, and the Dìr, Swāt, and Chitrāl Agency. The registered export to Afghānistān amounted in $1903-4$ to 1,285 tons, compared with 564 in $190 \mathrm{I}-2$.

Details of the quantities of salt sold for consumption within the Districts which lie west of the Indus in this Province and the Punjab, and of the revenue derived therefrom are given in the table on the next page. 


\begin{tabular}{|c|c|c|c|c|c|}
\hline - & $\begin{array}{l}\text { Quantity of } \\
\text { salt sold at } \\
\text { the mines in } \\
\text { Kohat Dis. } \\
\text { trict in tons. }\end{array}$ & $\begin{array}{c}\text { Imported } \\
\text { from Cis. } \\
\text { Indus mines } \\
\text { Division. }\end{array}$ & $\begin{array}{c}\text { Exported } \\
\text { beyond the } \\
\text { Province. }\end{array}$ & $\begin{array}{l}\text { Salt placed } \\
\text { for consump- } \\
\text { tion in the } \\
\text { area de- } \\
\text { scribed. }\end{array}$ & $\begin{array}{l}\text { Gross reve- } \\
\text { nue realized } \\
\text { exclusive of } \\
\text { miscellane- } \\
\text { ous receipts. }\end{array}$ \\
\hline $\begin{array}{l}1880-1 \text { to } 1889-90 \\
\text { (average) } \\
1890-1 \text { to } 1899-1900 \\
\text { (average) } \\
1900-1 . \\
1903-4 .\end{array}$ & $\begin{array}{l}20,614 \\
20,372 \\
16,011 \\
16,464\end{array}$ & $\begin{array}{l}\text { Figures not } \\
\text { a vailable. }\end{array}$ & $\begin{array}{c}\text { Figures not } \\
\text { available. } \\
\\
, 1 \\
9,913 \\
8,563\end{array}$ & $\begin{array}{l}\text { Figures not } \\
\text { available. }\end{array}$ & $\begin{array}{c}\text { Rs. } \\
1,79,624 \\
3,55,878 \\
7,01,510 \\
6,73,9^{6} 5\end{array}$ \\
\hline
\end{tabular}

The incidence of consumption per head was II.II lb. in $1898-9,7.0 \mathrm{r} \mathrm{lb}$. in 1900-r, and 7.43 lb. in 1903-4.

The people being mainly Muhammadan generally abstain Excise. from the use of intoxicating liquors, but not from drugs. Opium and charas are consumed in considerable quantities in Peshāwar and the tribal territories which adjoin that District, their place being taken by bhang in the two southern Districts of the Province. The use of spirituous liquor is virtually confined to the Hindu townspeople and the immigrant population of the cantonments. The consumption of intoxicants is, however, low as compared with the Punjab, being in $1903-4$ only $10.6 \mathrm{r}$ gallons of Indian spirit, $\mathrm{I} \cdot 45$ seers of opium, and $4: 43$ seers of hemp drugs for every 1,000 of the population in the British Districts. Whether the consumption is increasing or not it is impossible to say, as the population from which consumers are mostly drawn is to a large extent immigrant and varies in numbers. The incidence of consumption during the triennium ending 1903-4 shows a slight downward tendency.

Prior to annexation, the poppy was cultivated only to a limited extent in the frontier Districts, and its cultivation was gradually interdicted until, at the time of the formation of the Province in rgor, it had entirely ceased. The opium consumed now comes entirely from outside. The annual consumption is small, aniounting to only 60 or 70 maunds a year, and of this 24 maunds are allotted to the Province out of the 200 maunds of Bengal opium which the Benares Agency supplies annually to the Punjab. The latter is sold retail at Rs. 16 a seer, of which sum Rs. 7-8 is credited to the Province. Mālwā opium is imported direct from Ajmer and pays duty at the rate of Rs. 4 per seer, while some Kashmir and Afghān opium is admitted on payment of half that duty. Opium is produced in the Punjab, and opium which has already paid duty in that Province is admitted free of duty. The 
Province could be easily supplied with almost all the opium it needs from the Jalālābād valley of Afghānistān, but that source of supply is uncertain owing to the unsettled excise policy of the Amir.

Liquors Country spirit is prepared in two Government distilleries, at and drugs. Bannu and Dera Ismail Khãn, which supply Bannu and Dera Ismail Khān Districts, Peshāwar, Hazāra, and Kohāt Districts being supplied from the Rosa Distillery near Shāhjahānpur (United Provinces), or by wholesale vendors and private distilleries in the Punjab, whence free transport of spirit is allowed. The demand for spirit in Peshāwar District is considerable, amounting to about 10,000 gallons a year. This is due to the large consumption in the city.

There are no breweries in the Province, the Murree Brewery Company supplying the British troops in the garrisons at Peshāwar, Cherāt, and Naushahra, and the detachments which spend the summer in the Hazāra hills.

Hemp The hemp plant grows spontaneously in Hazāra, and along drugs the low hills which skirt the other Districts; but most of the bhang used comes from the Punjab, the drug being placed in bond on arrival until the duty (Rs. 4 a maund) has been paid. The consumption of bhang in the Districts of Bannu and Dera Ismail Khān is considerable. Charas produced in Central Asia is imported from the Punjab under bond. On the removal from bonded warehouses, duty is levied at the rate of Rs. 6. a seer. A certain amount of inferior charas from Bokhāra is probably smuggled via the Malakand into the Peshāwar valley through Chitrāl, and to prevent this the Mehtar of Chitrāl was required in 1904 to impose a prohibitive duty of Rs. 7 a seer on all charas transported through his territories.

Method The number and location of shops for the retail vend of
of vend. of vend. liquor, opium, and drugs in each District are determined each year by the Deputy-Commissioner and the licences are publicly auctioned. Licences for the sale of imported liquors and beer may be granted at fixed fees to respectable merchants in cantonments and to hotel-keepers and refreshment-rooms.

In the Agencies the Opium and Excise Acts are not in force, but arrangements have been made under executive authority in the Kurram and Tochi for the control of the sale of liquors and drugs. In the Kurram two shops have been licensed and in the Tochi seven, the licences for which realized Rs. 3,940 in 1903-4. The Dauris are notorious for their excessive use of drugs.

revenue. The total excise revenue in $1903-4$ amounted to 2 lakhs. 
Of this sum, Rs. 34,000 was realized on account of opium, Rs. 84,000 on account of country-made spirits and fermented liquors, Rs. 25,000 on account of imported spirits, Rs. 41,000 on account of charas, and Rs. 9,000 on account of bhang.

The net revenue from sales of stamps in 1903-4 was 2.3 Stamps lakhs in the case of judicial stamps, and 1.4 lakhs in the case and inof non-judicial. In the same year Rs. 99,000 was collected on account of income tax from 1,823 persons. The incidence of the tax per assessee was Rs. 42 , and 87 persons paid tax out of every 1,000 of the population.

The village community, characteristic of some parts of India, Local and is not indigenous among Pathāns. Its place as a social unit is, municipal. to some extent, taken by the tribe, which is held together by communithe ties of kindred and a common ancestry, real or imaginary. ties. So strong was the communal instinct in the tribes, that by the practice called vesh, traces of which still exist in Swāt and other independent territories (as among the ancient Greeks, Gauls, and Germans), all lands, water-rights, and even houses owned by any one tribe were periodically redistributed. Before annexation different branches of a tribe, or even different tribes, lived together for mutual protection; but such aggregations were not properly speaking village communities, for the headmen of one kandi or sub-section acknowledged no responsibility for, and claimed no authority over, the members of another kandi. As a result of British rule, something resembling the village community, in which the village headmen are jointly responsible for the whole, has been evolved; but the tribal division into kandis remains very marked.

The history of local self-government in this Province before Municipal its separation will be found in the article on the Punjab. No adminismunicipalities were constituted under Act XXVI of $185^{\circ}$; but between 1867 and 1873 Haripur and Kulāchi, and all the District head-quarters, except Kohāt, were made municipalities under Act XV of 1867 . By 1883 , Act IV of 1873 had been extended to these, as well as to Kohăt and five of the smaller towns, raising the number of municipalities to twelve. These were reconstituted under Act XIII of 1884 , and again under Act XX of r891, excepting the municipalities of Shankargarh and Pahārpur, which were abolished. The Province now possesses ten municipalities, which, in 1904, contained 162 appointed members, and 50 sitting ex-officio. Of these, $5^{1}$ were officials and only 23 Europeans. The total population within municipal limits in 1901 was 186,375 , of whom 73,343 were enumerated in Peshāwar, Dera Ismail Khān and Kohāt being 
the only other municipalities with a population exceeding ro, 000. In 1893, the town of Tānk was declared a 'notified area' under the Act of 1891 , and in 1903 the small sanitaria of Dunga Gali and Nathia Gali (the summer head-quarters of the Provincial Adninistration) were similarly constituted. The table on p. 89 gives the chief items of municipal income and expenditure. The incidence of taxation in 1903-4 was Rs. 2, and that of income Rs. 2-ro-9, per head of the population within municipal limits. Octroi is the chief source of income; and Haripur, Abbottābād, and Peshāwar are the only municipalities in which other forms of taxation are in force.

District boards.

Each of the five Districts of the Province has a District board, constituted under Act XX of 1883 . The members are all appointed by the Chief Commissioner. In the Haripur and Abbottābād tahsīls of Hazāra District the elective system was in force till 1903, when it was abolished. The total number of members in 1904 was 216 , of whom 49 were appointed ex-officio and 167 nominated. The two local boards of Bannu and Marwat, which existed when the Province was first con: stituted, were abolished in 1904 .

The income of a District board is mainly derived from the local rate, a consolidated cess of Rs. 10-6-8 per cent. on the land revenue. The expenditure is chiefly on education, the maintenance of dispensaries, vaccination, roads and resthouses, arboriculture, ferries, cattle-pounds, horse-breeding, and horse and cattle fairs. The greater part of the income being earmarked, there is little room for local initiative; and, as in the Punjab, the District boards are chiefly useful as consultative bodies.

Public All public works, except canals and railways, are in charge works. of the Commanding Royal Engineer, North-West Frontier Province, an officer of the Military Works department, who is also ex-officio Secretary to the Chief Commissioner. The revenue administration and maintenance of the Swāt River and Kābul River Canals and the maintenance of the Bārā River Canal are in charge of the Chief Engineer, Irrigation branch, Punjab, who is also ex-officio Secretary to the Chief Commissioner. The canals are directly managed by an Executive Engineer with head-quarters at Mardān, whose division is included in the circle of the Superintending Engineer, Jhelum Circle, Punjab. The Swāt River Canal was opened in 1885 . It was primarily constructed as a protective work, but has proved very remunerative, and irrigated a maximum area of about 250 square miles in 1903-4. The Kābul River Canal 
commenced irrigation in 1893 , and in $1903^{-4}$ irrigated about 45 square miles. The Hazār Khāni branch, an extension of this canal, is under construction, and in connexion with it a scheme for electric power for Peshāwar cantonment has been designed.

The total strength of the British and native army stationed Army. within the Province on June 1, 1903, was as follows: British, 2,946; native, 19,991 ; total 22,937. The Province is garrisoned by the Peshāwar and part of the Rãwalpindi divisions, and by three independent brigades, of the Northern Command. The military stations in 1904 were :-in the Peshâwar division, Chakdarra, Chitrāl, Dargai, Drosh, Jamrūd, Malakand, Mardān, Naushahra, and Peshāwar; in the Rāwalpindi division, Abbottābād; in the Kohāt brigade, Fort Lockhart, Hangu, Kohāt, and Thal; in the Derajāt brigade, Dera Ismail Khān, Drazinda, Jandola, Jatta, and Zām; and Bannu brigade, Bannu.

All these stations are garrisoned by native infantry and, if in the plains, by native cavalry also. British infantry regiments are cantoned at Peshāwar and Naushahra, British artillery at Peshāwar, and native artillery (mountain batteries) at most of the other stations. Sappers and miners are stationed at Peshāwar and Drosh.

Up to I886 a special military force entitled the Punjab Frontier Force, which was under the direct orders of the Government of the Punjab, maintained the peace of the border. In 1886 this force was transferred to the control of the Commander-in-Chief, and its regiments are no longer restricted to service on the frontier. The cavalry regiments are the 2 ist Prince Albert Victor's Own, the 22 nd, 23 $3^{\text {rd, } 25^{\text {th }} \text {, and Guides }}$ Cavalry. The infantry regiments, which rank as light infantry, are the Guides Infantry, the 5 Ist, $5^{2 n d}, 53^{\text {rd }}$ and $54^{\text {th }}$ Sikhs,

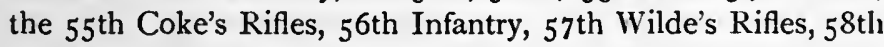
Vaughan's Rifles, 59th Scinde Rifles, and $5^{\text {th }}$ Gurkha Rifles. Prior to 1899 , the garrisons on the north-west frontier were largely scattered in isolated outposts, rendering concentration at any threatened point difficult. Since then a number of outlying garrisons have been withdrawn, their posts being handed over to militia and border military police, the total strength of which forces is just under 10,000 men, Under this scheme Naushahra has become a large cantonment, and mobile columns are kept always ready at Peshāwar, Mardān, Naushahra, Kohāt, Bannu, and Dera Ismail Khān.

The administration of the civil police force in the settled Police. Districts of the North-West Frontier Province is now vested in 
an Inspector-General. The force in each District is under a Superintendent, who works under the general control of the Deputy-Commissioner (District Magistrate). Three Assistant Superintendents are also posted to Peshāwar District.

After the annexation of the Punjab, the police duties in the Trans-Indus Districts were carried out by a force known as the Peshāwar and Derajāt mounted and foot levies or political contingent, which was under the control of the Deputy-Commissioner in each District. This force consisted of local tribesmen nominated by their chiefs, and its cost included subsidies to them. Just as in recent years the disciplined and orderly militia corps have been evolved from tribal levies, so this political contingent, in its civil aspect, was gradually transformed into a regular police force, while in its tribal aspect it has now been supplanted by the border military police. In I 863 the contingent was brought under the general police system of the Punjab, and placed for purposes of inspection under the Inspector-General of Police. In 1870 the Police Act was applied partially, and in 1889 it was applied in its entirety. The constables and subordinate officers of the civil police now form a Provincial service, but the gazetted officers are borne on the cadre of the Punjab police and receive promotion and acting allowances in the list of that Province.

Proportion The strength of the force within the five British Districts of to area and the Province is 3,006 sergeants and constables, giving an popula- average of one man to 4.4 square miles and to 700 persons. tion. The unit of administration is the thana or police station, under a sub-inspector, and road-posts and outposts are established where necessary. Nearly four-fifths of the force are armed with bored-out Martini-Henry rifles and bayonets. Every constable is also provided with a sword and baton. In regard to recruitment, the Police department has to compete with the army and militia, which offer better pay and prospects. It inevitably results that the best material is not attracted to the force. The training of constables is carried on in the Districts in which they are enlisted, but the superior grades are eligible for training in the Police school at Phillaur in the Punjab. Crime is watched by a special branch at head-quarters in charge of an Assistant Superintendent, but there is no separate force of detective police. Trained recorders of finger impressions are maintained in each District, but the central bureau used is that at Phillaur.

Rural police.

The village watchmen or chaukidärs are appointed by the District Magistrate, on the recommendation of the village 
headmen. They provide their own arms, and are paid in kind by the proprietary body of the village to which they belong at the rate of Rs. 3 per month. Their duties are similar to those in other Provinces, but they are regarded as acting under the control of the village headmen, and as jointly responsible with the latter for the reporting of crime. In executive duties they are under the orders of the tahsildār, but in all matters relating to the prevention and detection of crime and the collection of information they report to the police.

In the large towns municipal funds contribute towards the Municipal, up-keep of the local police, and in cantonments special police Cantonare paid partly from Local funds ; in some Districts ferry police Fentr, and are paid by the District boards. All these, however, are under Railway the control of the Superintendent of Police of the District. The Railway police form part of the general system of the Punjab Railway police, and are under the control of that Government. No tribes have been registered under the Criminal Tribes Act.

Statistics of cognizable crime (that is, offences for which the Cognizable police may arrest without a magistrate's warrant) are shown crime. below :-

\begin{tabular}{|lr|r|r|}
\hline \multicolumn{2}{|c|}{ Number of cases. } & Ig02. & 1903. \\
\cline { 1 - 3 } Reported . & $\cdot$ & 6,692 & 6,267 \\
Decided in the courts &. & 4,785 & 4,676 \\
Ending in acquittal or discharge & 823 & 773 \\
Ending in conviction . & $\cdot$ & $3,53^{2}$ & 3,487 \\
\hline
\end{tabular}

In the earlier days of the occupation of the frontier, the Border British sphere of influence was limited entirely to the plains. Military Little was known of the tribes living in the hill country across the border, and hardly any control was exercised over them. It was not even until a comparatively recent date that the question was finally decided as to whether many of these tribes came under Afghãn or British jurisdiction. To guard against the constant incursions and raids of these tribesmen into British territory, the border military police was created out of what was known as the old frontier militia. The force was originally organized purely on the silladari $i$ system. The leading Khāns and headmen living within the border received allowances, in return for which they produced a certain number of horse or footmen. The system naturally led to grave abuses. Vacancies were left unfilled: horsemen were without horses; and boys and old men, equally incapable of work, were nominated as foot-soldiers. The silladäri system was in consequence abolished, and the border military police is now on the same 
footing as any other force as regards pay and enlistment. The duties remain the same, but the advance of British occupation across the border and the creation of the new militia corps have contributed further to the peace of the border.

The border military police corps under the control of the Deputy-Commissioner in each District is commanded by an Assistant Commissioner, usually a military officer in civil employment, except in Kohăt, where the commandant is an officer of police. The men are armed with Martini-Henry rifles, and are employed in garrisoning posts distributed along the administrative border, with a reserve at each head-quarters. The strength of the five corps is 2,061 men, of whom 289 are mounted.

Militia When the Agencies across the administrative border were and Levy first occupied, they were garrisoned entirely by regular troops ; Corps. but levies were raised from among the local tribesmen to convoy travellers, collect information, and act as a means of communication between the Political officers and the tribes. From these levies have been raised the present militia corps, which contain an equal proportion of men living on either side of the administrative border, and thus combine the advantages of local levies with the steadying element of outside influences. In all the Agencies except Dìr, Swāt, and Chitrāl, the levy corps have been disbanded, and the policy is being carried out of relieving the regular troops of the onerous and expensive work of garrisoning trans-border outposts. Chitrāl, Drosh, Chakdarra, the Malakand, Drazinda in the Shirāni country, and Jandola in Southern Waziristān are now the only posts in the Agencies at which a garrison of regular troops is maintained. These corps are officered by British military officers, seconded for a period of five years from their regiments. Their armament is the Martini-Henry rifle, Mark II. Although strictly speaking a border military police corps, the Samāna Rifles are generally counted in Kohăt District with militia corps; their armament and equipment are the same as those of the militia corps, but their British officers belong to the Punjab police. The total strength of the militia corps is 6,033 men, of whom $33^{6}$ are mounted.

Chitrāli

The experiment has also been lately tried of raising in Scouts. Chitrāl a corps of scouts organized on the old feudal system of the country, with the Mehtar of Chitrāl as honorary commandant. The object is the creation of a body of trained marksmen to defend the passes into Chitrāl in the event of invasion. The corps has two British military officers, and the scheme contemplates the training of 1,200 men. The force 
is organized on an entirely different system from the militia corps, as its members are only called out for training in batches for two months in the year, and when not under training return to ordinary civil life. They are armed with $\cdot 3 \circ 3$ rifles.

With the exception of the Bhittanni Levies in Dera Ismail Levy Khān District, whose absorption in the Southern Wazīristān Corps. Militia is under contemplation, the only levy corps still existing are those in the Dir, Swāt, and Chitrāl Agency. The Dīr levies are, armed with rifles supplied by Government, but are under the orders of the Nawāb of Dirr. The principal responsibilities of this force are the security of communications, mail escorts, and the maintenance of order on the Chakdarra-Chitrāl road.

The Jail department is under the control of the Administra- Jails. tive Medical Officer of the Province. The number of jails (5) has remained unchanged since $188 \mathrm{I}$. Those at Peshāwar and Abbottābād are in charge of the Civil Surgeon of the District, while the others, at Dera Ismail Khăn, Bannu, and Kohăt, are in charge of the military medical officers who hold collateral medical charge of the Districts. These are all District jails, and there are no Central or subsidiary jails, long-term prisoners being transferred to Cis-Indus jails, while the large judicial lock-ups at Mardān in Peshāwar District and at Teri and Hangu in Kohăt fulfil the requirements of subsidiary jails.

The following table gives the chief statistics of jails for a series of years :-

\begin{tabular}{|c|c|c|c|c|}
\hline & $188 \mathrm{I}$. & $189 \mathrm{r}$. & 1901. & 1904. \\
\hline $\begin{array}{l}\text { Number of District jails. } \\
\text { Number of subsidiary jails } \\
\text { (lock-ups). }\end{array}$ & 5 & $\begin{array}{l}5 \\
2\end{array}$ & $\begin{array}{l}5 \\
2\end{array}$ & $\begin{array}{l}5 \\
3\end{array}$ \\
\hline $\begin{array}{l}\text { Average daily population :- } \\
\text { (a) Male : } \\
\text { (b) Female : }\end{array}$ & $\begin{array}{r}1,649 \\
63\end{array}$ & $\begin{array}{r}1, I 59 \\
55\end{array}$ & $\begin{array}{r}1,19 I \\
43\end{array}$ & $\begin{array}{r}1,233 \\
47\end{array}$ \\
\hline Total & 1,712 & 1,214 & I, 234 & 1,280 \\
\hline $\begin{array}{l}\text { Rate of jail mortality per } \mathrm{I}, 000 \\
\text { Expenditure on jail main- } \\
\text { tenance : } \\
\text { Cost per prisoner : } \\
\text { Profits on jail mannfactures Rs. } \\
\text { Earnings per prisoner } \text { Rs. Rs. }\end{array}$ & $\begin{array}{c}70.68 \\
1,10,982 \\
64-13-2 \\
20,418 \\
15-9-2\end{array}$ & $\begin{array}{c}25 \cdot 54 \\
81,498 \\
67-2-1 \\
10,486 \\
10-12-5\end{array}$ & $\begin{array}{c}12 \cdot 16 \\
91,048 \\
73^{-12-6} \\
7,457 \\
8-13-0\end{array}$ & $\begin{array}{l}14 \cdot 84 \\
87,786 \\
68-9-4 \\
7,084 \\
7-10-0\end{array}$ \\
\hline
\end{tabular}

The daily average number of prisoners in 1881 and the three preceding years was abnormally high, a result of the 
succession of bad harvests which began in the autumn of 1877 , and the drain of food-grains from the Province for the armies serving in Afghānistann. The unrest on the frontier also caused large numbers of persons to be sentenced to imprisonment in default of security for good behaviour. The steady decrease in mortality is largely due to the immunity from typhus fever enjoyed by prisoners of recent years. This disease was endemic in the Frontier Districts and more especially in the Peshāwar valley, and caused as many as $5^{8}$ deaths in the Peshāwar jail in 188r. Dysentery and pneumonia have also ceased to be so fatal as they were twenty years ago. The expenditure incurred on measures to improve the condition of jail life, together with the higher prices of food-grains and other articles, accounts for the steady rise in the daily average cost of maintenance per head during recent years. The earnings in $188 \mathrm{I}$ were unusually large, a result of the employment of prisoners at Peshāwar on the railway then under construction in the vicinity of the jail, while the drop in the earnings of $r 90 r$, as compared with those of 1891 , is due to alterations in the method of account. The chief industries carried on in the jails are paper-making, lithographic printing, weaving, and oil-pressing. Most of the out-turn is supplied to Government departments.

Present organization.

As now constituted, the inspecting staff of the Educational department in the North-West Frontier Province consists of an Inspector-General of Education, a Personal Assistant, and 4 District Inspectors. Most Districts have a District Inspector, but Kohāt, Bannu, and Daur in Northern Wazīistān are in charge of one District Inspector. The schools of the Kurram valley are inspected twice a year by the head master of the municipal high school at Kohāt.

The Province possesses no University of its own, and its only college is affiliated to the Punjab University at Lahore. The number of matriculations was 15 in 1891 , 98 in 190r, and $7 \mathrm{r}$ in 1903 .

Collegiate The only college in the Province is the Edwardes Church education. Mission College at Peshāwar, opened in 1900-r. Seven of its scholars passed the Intermediate examination of the Punjab University in 1903 .

Secondary The school curriculum is the same as that in force in the education. Punjab. At the close of $1903-4$ the Province possessed 25 secondary schools, of which 15 were Anglo-vernacular (8 maintained by local bodies, 4 aided, and 3 unaided), and 10 vernacular schools, all maintained by local bodies. These 
schools contained $\mathbf{1}, 42 \mathrm{I}$ pupils, excluding pupils in their primary departments.

At the close of $1903-4$ the Province possessed 172 primary Primary schools for boys, of which I 45 were maintained by local education bodies, 2 I (mostly indigenous) were aided, and 6 unaided. These and the primary departments of the secondary schools contained II,959 pupils.

The Province possesses 8 girls' schools, namely: 4 maintained Female by local bodies, 3 aided, and one unaided. These contained education. 578 pupils in $1903-4$, in addition to which 1,721 girls were receiving. instruction in private schools, and $2 \mathrm{I}$ in boys' schools, so that 2,316 girls in all were under instruction. These comprised $\mathrm{r}, 38 \mathrm{r}$ Muhammadans, $78 \mathrm{r}$ Hindus, 153 Sikhs, and one native Christian. The municipal girls' schools at Dera Ismail Khān and Kohāt admit Muhammadan girls only, and Urdū is the medium of instruction. The other public schools are attended almost entirely by Hindus and Sikhs, and Gurmukhī or Hindī is taught in them. Dera Ismail Khān District returns the largest number of girl pupils (258), Hazära 103, Kohāt 85 , Bannu and Peshāwar 64 girls each.

In r $903-4$ only 1 ro per 1,000 of the number of Muham- Mahammadan boys of school-going age attended schools of all kinds, madan madan boys of school-going age attended schools of all kinds, education. and only 9,045 Muhammadans attended public schools for boys. Relatively the Muhammadan community is, in this Province, far behind the Hindus and Sikhs, from an educational standpoint. It is, however, progressing and, though progress is slow, there are signs of a wakening in Hazāra and Kohāt Districts. Muhammadan education is specially encouraged by the award of 9 high and $\mathrm{r}_{3}$ middle-school Victoria scholarships annually; and to foster it among the border tribes 5 stipends are awarded to Wazīr and Shirāni boys, and 4 to Dauri boys, and two stipends have recently been granted to Mohmand Pathān boys in Peshāwar District. Special schools for Muhammadans are maintained at Dera Ismail Khān, Bannu, and Abbottābād. All these are elementary, but Peshāwar possesses an Islāmiya Anglo-vernacular high and an Anglo-vernacular middle school.

In 1903-4 there were 206 public and 744 private schools, in Statistics. which 26,439 pupils of both sexes were being educated. This number is equivalent to 8 per cent. of the children of school-going age in the administered portion of the Province. The total expenditure amounted to Rs. 1,91,000. The number of girls in receipt of instruction was 2,326 , of whom less than half were Muhammadans.

Only one newspaper is published in the North-West Frontier 
Medical. Hospitals and dispensaries.

Province, the Tuhfa-i-Sarhadd, a weekly Urdū journal issued by the Bannu Mission and devoted to missionary enterprise.

The Medical department is under an Administrative Medical Officer. Two of the five British Districts and three of the Political Agencies are in charge of whole-time civil surgeons. Military medical officers are in collateral charge of the other Districts and Agencies. A Military assistant surgeon is in medical charge of the Khyber. Assistant surgeons are in subordinate charge of hospitals and dispensaries at the head-quarters of Districts and subdivisions. Minor dispensaries are in charge of Hospital Assistants of different grades. There are female dispensaries at Peshāwar and Kohāt, under female medical subordinates. The supply of Hospital Assistants is obtained chiefly from the Lahore medical school.

Of the 39 hospitals and dispensaries 17 are maintained wholly, and one is aided, by Government. The others are maintained from Local and municipal funds. In 1904 there were 345 beds for males and $\mathrm{r} 30$ for females. The most important institution is the Egerton Hospital at Peshāwar, with accommodation for 42 male and $\mathrm{r} 2$ female in-patients. It is maintained from Local and municipal funds. An institution for the relief of lepers at Bāla Pīr's Ziārat, at Bālakot, Hazāra District, is supported by private subscriptions and to some extent by Local funds. The Church Missionary Society provides a large share of the medical relief available in the Province. It maintains the Duchess of Connaught Hospital for women at Peshāwar, and hospitals or dispensaries at Peshāwar, Bannu, Dera Ismail Khān, and Tānk. These institutions are not included in the statistics attached to this article. In 1901 they treated 1,139 in-patients and 36,960 out-patients, and in 19042,527 in-patients and 59,593 outpatients. The number of operations performed was $3,5^{88}$ in 1902 and 4,330 in 1904 .

Lnnatic asylums.

Vaccina. 1ion.

There is no lunatic asylum in the Province, and patients are sent to the Punjab.

The Administrative Medical Officer is in charge of the Vaccination department. There are two divisional Inspectors for the Province, whose duties also include the checking of the registers of births and deaths. Each District has a native supervisor and a varying number of vaccinators supervised by the civil surgeon. The Kurram and Tochi Agencies have each one vaccinator. Small-pox is very common among the Pathāns, especially across the border. Vaccination is popular, but its extension is seriously interfered with by inoculation, an 
art practised by certain families and handed down from father to son. At the same time these practitioners are not bigoted adherents of their system; and excellent results have been obtained in Yūsufzai and neighbouring tracts by inducing them to learn vaccination, and then sending them back to their tribes not as inoculators but as vaccinators.

Surveys in the North-West Frontier Province have been Surveys. the work of two distinct agencies, the Survey department and the local Revenue establishment. Peshāwar was surveyed by officers of the Survey department between $186_{3}$ and 1870 , and Bañnu and Dera Ismail Khān between 1874 and 1878 ; Hazāra between 1865 and 1869 , and again partially in $1888-92$; Kohāt was topographically surveyed on the one-inch-to-themile scale in the years $1880-3$.

In independent territory surveys have until the last two years been possible only when an expedition was in progress. Geographical reconnaissances based on triangulation were carried out in Chitrāl, Dìr, and Swāt in 1885, r 892 , r 893 , I 895, and I90I, and maps on the quarter-inch scale have been prepared. The more important passes in Chitrāl were again surveyed in r904-5. In r897-8 Bājaur and Buner, with part of Swāt and the Mohmand and Mamund countries, were roughly surveyed on the half-inch scale. A survey of the Khyber and part of the Tīrāh on the one-inch scale was carried out in $1878-9$, and survey operations in the latter country were extended during $1897-8$. The settlement maps of Peshāwar were revised in $1890-4$; those of Hazāra, Kohāt, Dera Ismail Khān, and Bannu are either still under revision or have been recently brought up to date. Reconnaissance maps of the Kurram valley on the quarter-inch scale were made in $1878-80$, and the valley was again surveyed on the one-inch scale in 1894 and 1898 . The cultivated area is now again under survey, in connexion with the settlement operations.

Waziristãn has been the scene of desultory operations whenever occasion offered since 1860 , and maps of the whole country on the half and quarter-inch scales exist, most of the work having been done since r894. Survey operations are again in progress.

Further information concerning the North-West Frontier BiblioProvince will be found in the Punjab Border and General graphy. Administration Reports for the years from $185 \mathrm{I}-2$ to $1900-\mathrm{r}$, and in the annual Provincial Reports which have been published since rgor; in the Punjab Census Reports of $187 \mathrm{I}$, 1881, 1891, and in the Punjab and North-West Frontier 
Province Census Report of rgor. Among the standard works on subjects connected with the North-West Frontier Province may be mentioned : H. W. Bellew : Punjab Frontier (1868).-Maxwell : Buddhist Explorations in the Peshazvar District (1882).-Cole : Memorandum on Ancient Monuments in Yüsafzai (1883).-M. A. Stein : Archaeological Tour in the Buner Country (1898).-Major H. B. Edwardes: A Year on the Punjab Frontier, 1848-9 (185I).-R. Bosworth Smith : Life of Lord Lazurence (1901).-Lady Edwardes : Life and Letters of Major-General Sir H. B. Edwardes (1886).Captain L. J. Trotter: Life of John Nicholson (1905).-Lord Roberts : Forty-one Years in India (1902).-H. W. Bellew : Grammar and Dictionary of the Pashtu Language (1901).J. Darmesteter: Chants Populaires des Afghans (Paris, 1888-90).-J. G. Lorimer : Grammar and Vocabulary of Waziri Pashtu (1902).-Paget and Mason: Record of Expeditions against the North-West Frontier Tribes (1849-85).The Pathān Revolt of 1897 (Lahore). 


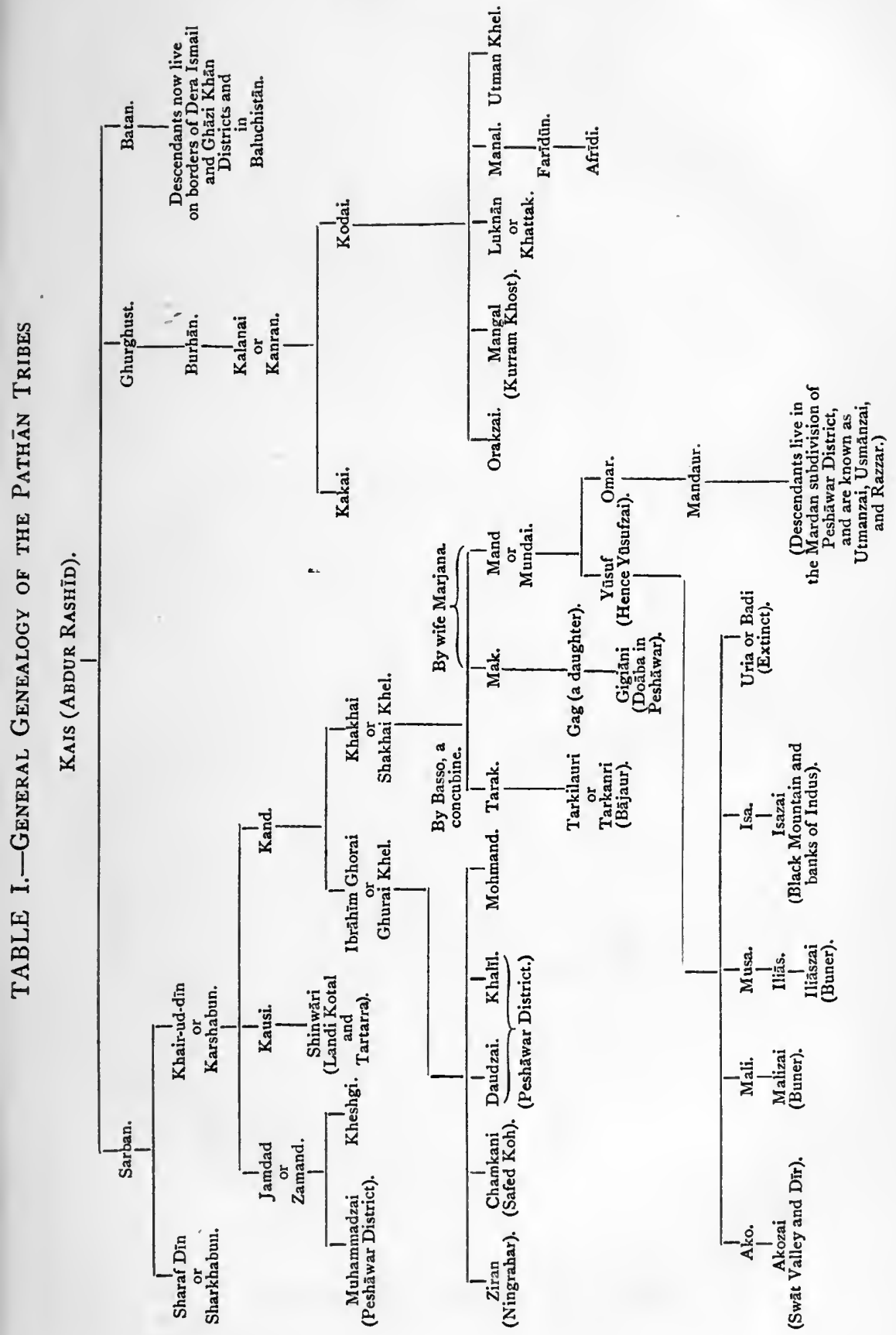




\section{TABLE II}

\section{Expeditions undertaken against Frontier Tribes since} the Annexation of the Punjab

\begin{tabular}{|c|c|c|c|c|}
\hline Year. & $\begin{array}{c}\text { Tribes against } \\
\text { which undertaken. }\end{array}$ & Name of Commander. & $\begin{array}{l}\text { Number of Iroops } \\
\text { employed *. }\end{array}$ & $\begin{array}{l}\text { Total } \\
\text { British } \\
\text { casual- } \\
\text { ties. }\end{array}$ \\
\hline 1849 & $\begin{array}{l}\text { Villages of British } \\
\text { and independent } \\
\text { Baeza (Swāt). }\end{array}$ & $\begin{array}{l}\text { Lieutenant-Colonel J. } \\
\text { Bradshaw, C. B. }\end{array}$ & 2,300 & 51 \\
\hline 1850 & Kohāt Pass Afrìdis. & $\begin{array}{l}\text { Brigadier Sir Colin } \\
\text { Campbell, K.C.B., } \\
\text { (accompanied by } \\
\text { the Commander- } \\
\text { in-Chief, General } \\
\text { Sir C. J. Napier, } \\
\text { G.C.B.). }\end{array}$ & 3,200 & 94 \\
\hline 1851 & $\begin{array}{l}\text { Villages of British } \\
\text { Mīrānzai. }\end{array}$ & Captain J. Coke & $\begin{array}{l}\text { (inclnding } \\
\text { levies). }\end{array}$ & 5 \\
\hline $185^{1-2}$ & Mohmands . & $\begin{array}{c}\text { Brigadier Sir Colin } \\
\text { Campbell, K.C.B. }\end{array}$ & 1,597 & 9 \\
\hline $185^{2}$ & $\begin{array}{l}\text { Mohmands (Affair } \\
\text { at Panjpao). }\end{array}$ & " & 600 & 10 \\
\hline$"$ & $\begin{array}{l}\text { Ravizai : } \\
\text { Utman Khel : }\end{array}$ & $"$ & $\begin{array}{l}3,270 \\
2,200\end{array}$ & $\begin{array}{l}40 \\
18\end{array}$ \\
\hline$"$ & $\begin{array}{l}\text { Umarzai(Ahmadzai) } \\
\text { Wazirs. }\end{array}$ & Major J. Nicholson . & $\begin{array}{l}2,200 \\
1,500\end{array}$ & $\begin{array}{l}18 \\
28\end{array}$ \\
\hline $185^{2-3}$ & Hasanzai & $\begin{array}{c}\text { Lieutenant - Colonel } \\
\text { F. Mackeson, C.B. }\end{array}$ & $\begin{array}{l}3,800 \\
\text { (including Kashmīr } \\
\text { troops, levies, and } \\
\text { police, but exclnd- } \\
\text { ing the reserve). }\end{array}$ & 18 \\
\hline 1853 & Hindustāni Fanatics & $"$ & $\begin{array}{l}2,000 \\
\text { (including Kashmir } \\
\text { troops). }\end{array}$ & Nil \\
\hline$"$ & Shirānis . $\quad \cdot$ & $\begin{array}{l}\text { Brigadier J. S. Hodg- } \\
\text { son. }\end{array}$ & 2,795 & $\mathrm{Nil}$ \\
\hline $1 \ddot{8}_{54}$ & $\begin{array}{l}\text { Bori Afridis } \\
\text { Michni Mohmands . }\end{array}$ & $\begin{array}{l}\text { Colonel S. B. Boileau } \\
\text { Colonel S. J. Cotton }\end{array}$ & $\begin{array}{l}1,740 \\
1,782\end{array}$ & $\begin{array}{l}39 \\
17\end{array}$ \\
\hline I 855 & Aka Khel Afridis . & $\begin{array}{l}\text { Lieutenant-Colonel J. } \\
\text { H. Craigie, C.B. }\end{array}$ & 1,500 & 34 \\
\hline " & $\begin{array}{l}\text { Villages of British } \\
\text { Mirānzai. } \\
\text { Rabia Khel Orakzais }\end{array}$ & $\begin{array}{l}\text { Brigadier N.B.Cham - } \\
\text { berlain. }\end{array}$ & 3,766 & I5 \\
\hline 1856 & $\begin{array}{l}\text { Rabia Khel Orakzais } \\
\text { Turis } \\
\text {. }\end{array}$ & " $\quad$ " & $\begin{array}{cc}2,457 \\
4,896 \\
\text { (including } \\
\text { levies). }\end{array}$ & 15 \\
\hline 1857 & $\begin{array}{l}\text { British villages on the } \\
\text { Yūsufzai border. }\end{array}$ & Major J. L. Vaughan & $\begin{array}{l}400 \\
\text { In attack on Shaikh } \\
\text { Jana. } \\
\text { (including } 990 \\
\text { levies) in the first } \\
\text { attack on Narinji. } \\
1,625 \\
\text { (inclading } 323 \text { le- } \\
\text { vies) in the second } \\
\text { attack on Narinji. }\end{array}$ & $\begin{array}{l}5 \\
26\end{array}$ \\
\hline
\end{tabular}

- The numbers yiven in this column are in some cases only approximate, it heing impossible in these cases to discover from the records the exact number of troops employed. 


\section{TABLE II (continued)}

Expeditions undertaken against Frontier Tribes since the Annexation of the Punjab

\begin{tabular}{|c|c|c|c|c|}
\hline Year. & $\begin{array}{c}\text { Tribes against } \\
\text { which undertaken. }\end{array}$ & Name of Commander. & $\begin{array}{l}\text { f troops } \\
\text { red *. }\end{array}$ & $\begin{array}{c}\text { Total } \\
\text { British } \\
\text { casual- } \\
\text { ties. }\end{array}$ \\
\hline 1859 & $\begin{array}{l}\text { Khel and Hin- } \\
\text { ni Fanatics. }\end{array}$ & $\mathrm{J} . \mathrm{C}$ & 4,877 & 35 \\
\hline $1859-60$ & Khel Wazirs. & $\begin{array}{l}\text { Brigadier-General Sir } \\
\text { N. B. Chamberlain, } \\
\text { C.B. }\end{array}$ & $\begin{array}{c}\text { (including I, } 57^{2} \\
\text { police and levies). }\end{array}$ & 20 \\
\hline 1860 & Mahsūds. &  & $\begin{array}{l}\text { (including } \\
\text { levies). }\end{array}$ & 361 \\
\hline 1863 & Hindustāni Fanatics & $\begin{array}{l}\text { Brigadier-General Sir } \\
\text { N. B. Chamberlain, } \\
\text { K.C.B., and sub- } \\
\text { sequently Major- } \\
\text { General J. Garvok. }\end{array}$ & 9,000 & 908 \\
\hline 1864 & Mohmands . & $\begin{array}{l}\text { Colonel A. Mac- } \\
\text { donell, C.B. }\end{array}$ & I, $80 \mathrm{I}$ & I9 \\
\hline 1868 & Bizoti Orakzai. & Major L. B. Jones & \begin{tabular}{c}
\multicolumn{2}{c}{970} \\
(including \\
police and levies).
\end{tabular} & 55 \\
\hline$"$ & $\underset{\text { Tribes. }}{\text { Black }}$ Mountain & $\begin{array}{l}\text { Major-General A. T. } \\
\text { Wilde, C.B., C.S.I. }\end{array}$ & $\begin{array}{c}12,544 \\
\text { (exclnsive of a re- } \\
\text { serve of } 2,218 \text { ) }\end{array}$ & $98+$ \\
\hline 1869 & Bizoti Orakzai. & $\begin{array}{l}\text { Lientenant - Colonel } \\
\text { C. P. Keyes, C.B. }\end{array}$ & $\begin{array}{l}\text { serve of 2,218). } \\
\text { 2,080 } \\
\text { (including } 4 \text { 4I9 }\end{array}$ & 36 \\
\hline 1872 & Dauris . & $\begin{array}{l}\text { Brigadier-General C. } \\
\text { P. Keyes, C.B. }\end{array}$ & 1,826 & 6 \\
\hline 1877 & Jow: & Colonel D. Mocatta. & $\begin{array}{l}1,75^{\circ} \\
\text { (exclusive } \\
\text { levies). }\end{array}$ & I I \\
\hline $1877-8$ & ITtmon Thl & $\begin{array}{l}\text { Brigadier-Gene } \\
\text { P. Keyes, C.I } \\
\text { C. C. G. Ros }\end{array}$ & 7,400 & $6 i$ \\
\hline $\begin{array}{c}1878 \\
, "\end{array}$ & $\begin{array}{l}\text { Utman Khel : } \\
\text { Rānizai : }\end{array}$ & $\begin{array}{l}\text { Captain W. Battye } \\
\text { Major R. B. P. P. }\end{array}$ & $\begin{array}{l}280 \\
860\end{array}$ & $\begin{array}{c}8 \\
N i l\end{array}$ \\
\hline " & Utman Khel . & $\begin{array}{l}\text { Lientenant - Colonel } \\
\text { F. H. Jenkins. }\end{array}$ & 875 & I \\
\hline$"$ & Zakka Khel Afrīdis. & $\begin{array}{l}\text { Lieutenant - Colonel } \\
\text { F. F. Maude, V.C., } \\
\text { C.B. }\end{array}$ & 2,500 & I I \\
\hline$"$ & $\begin{array}{l}\text { Powindas, Sulaimān } \\
\text { Khel, and others. }\end{array}$ & $\underset{\text { Boisragon. }}{\text { Colonel H. }}$. & 640 & 13 \\
\hline 1879 & Zakka Khel Afrìdis. & $\begin{array}{l}\text { Lieutenant - Colonel } \\
\text { F. F. Mande, V.C., } \\
\text { C.B. }\end{array}$ & $3,75^{\circ}$ & 18 \\
\hline " & $\begin{array}{l}\text { Mohmands (Affair } \\
\text { at Kam Dakka). }\end{array}$ & $\begin{array}{l}\text { Captain O'M.Creagh, } \\
\text { and subsequently } \\
\text { Major J. R. Dyce. }\end{array}$ & 600 & 24 \\
\hline$"$ & Zaimukhts & $\begin{array}{l}\text { Brigadier-General J. } \\
\text { A.Tytler,V.C.,C.B. }\end{array}$ & 3,226 & 5 \\
\hline
\end{tabular}

* The numbers given in this column are in some cases only approximate, it being impossible in these cases to discover from the records the exact number of troops emplojed.

+ This number includes the casualties $(64)$ in the Agror valley previous to the advance of the Hazara Field Force. 


\section{TABLE II (continued)}

Expeditions undertaken against Frontier Tribes since the Annexation of the Punjab

\begin{tabular}{|c|c|c|c|c|}
\hline Year. & $\begin{array}{c}\text { Tribes against } \\
\text { which undertaken. }\end{array}$ & Name of Commander. & $\begin{array}{l}\text { Number of troops } \\
\text { employed }\end{array}$ & $\begin{array}{l}\text { Total } \\
\text { British } \\
\text { casual- } \\
\text { ties. }\end{array}$ \\
\hline 1880 & Mohmands & $\begin{array}{l}\text { Brigadier-General J } \\
\text { Doran, C.B., and } \\
\text { Colonel T. W. R. } \\
\text { Boisragon. }\end{array}$ & 2,300 & 5 \\
\hline$"$ & Bhittannis - & $\begin{array}{l}\text { Lieutenant - Colonel } \\
\text { P. C. Rynd. }\end{array}$ & 721 & 5 \\
\hline$"$ & $\begin{array}{l}\text { Kābul Khel (Utman- } \\
\text { zai) Wazīrs. }\end{array}$ & $\begin{array}{l}\text { Brigadier-General J. } \\
\text { J. H. Gordon, C.B. }\end{array}$ & 800 & Nil \\
\hline 1881 & Mahsūds & $\begin{array}{l}\text { Brigadier-GeneralsT. } \\
\text { G. Kennedy, C.B., } \\
\text { and J. J. H. Gor- } \\
\text { don, C.B. }\end{array}$ & $8,53^{1}$ & 32 \\
\hline 1888 & $\begin{array}{l}\text { Hasanzai, Akozai, } \\
\text { Parari Saiyids and } \\
\text { Tikariwal. }\end{array}$ & $\begin{array}{l}\text { Major-General J. W. } \\
\text { McQueen, C.B., } \\
\text { A.-D.-C. }\end{array}$ & 12,554 & \\
\hline 1890 & $\begin{array}{c}\text { Kidderzai Section of } \\
\text { Largha Shirānis. }\end{array}$ & $\begin{array}{r}\text { General Sir G. S. } \\
\text { White,V.C.,G.C.B. }\end{array}$ & $1,750+$ & $\mathbf{I}$ \\
\hline 1891 & Hasanzai and Akozai & $\begin{array}{l}\text { Major-General W. K. } \\
\text { Elles, C.B. }\end{array}$ & 7,300 & $4^{8}$ \\
\hline$"$ & Orakzai . • & $\begin{array}{l}\text { Major-General Sir } \\
\text { W.S. A. Lockhart, } \\
\text { K.C.B., C.S.I. }\end{array}$ & $7,3^{81}$ & 95 \\
\hline $\begin{array}{r}189^{2} \\
1804-5\end{array}$ & $\begin{array}{l}\text { Isazai Clans : } \\
\text { Mahsūds }\end{array}$ & $" n$ & $\begin{array}{r}5,997 \\
10,631\end{array}$ & $\begin{array}{c}\text { Nil } \\
23\end{array}$ \\
\hline $1896^{\circ}$ & $\begin{array}{l}\text { Umra Khãn of Jan- } \\
\text { dol (Chitral Relief } \\
\text { Force). }\end{array}$ & $\begin{array}{l}\text { Major-General Sir R. } \\
\text { C. Low, K.C.B. }\end{array}$ & 14,900 & 122 \\
\hline I 897 & $\begin{array}{l}\text { (I) Swătis and Ut- } \\
\text { man Khel. } \\
\text { (2) Bunerwal and } \\
\text { Chamlawal. } \\
\text { Darwesh Khel Wazirs }\end{array}$ & $\begin{array}{l}\text { Major - General Sir } \\
\text { Bindon Blood, } \\
\text { K.C.B. }\end{array}$ & 8,071 & $53^{2}$ \\
\hline ", & Mohmands. • & $\begin{array}{l}\text { Major-General E. R. } \\
\text { Elles, C.B. }\end{array}$ & $6,45^{8}$ & 30 \\
\hline $1897-8$ & Darwesh Khel Wazirs & $\begin{array}{l}\text { Major-General G. } \\
\text { Corrie-Bird, C.B. }\end{array}$ & 7,262 & 17 \\
\hline , & Afrìdis and Orakzai. & $\begin{array}{l}\text { Major-General Sir } \\
\text { W.S. A. I.ockhart, } \\
\text { K.C.B., K.C.S.I. }\end{array}$ & 40,000 & 1,019 \\
\hline $1900-1$ & Mahsūds. & $\begin{array}{l}\text { General W. Hill, } \\
\text { C. B., from De- } \\
\text { cember I, 1900, } \\
\text { to August, 1901. } \\
\text { Thereafter Briga- } \\
\text { dier-General Den- } \\
\text { ning, D.S.O. }\end{array}$ & $12,44^{8}$ & 136 \\
\hline 1902 & $\begin{array}{l}\text { Kābul Khel (Utman- } \\
\text { zai) Wazirs. }\end{array}$ & $\begin{array}{l}\text { Major-General Sir C. } \\
\text { C. Egerton, K.C.B., } \\
\text { I.S.O. }\end{array}$ & 2,880 & 21 \\
\hline
\end{tabular}

* The numbers given in this column are in some cases only approximate, it being impossible in these cases to discover from the records the exact number of troops employed.

+ Number of Punjab columns only: two other columns, operating from Baluchistân, took part in the expedition. 

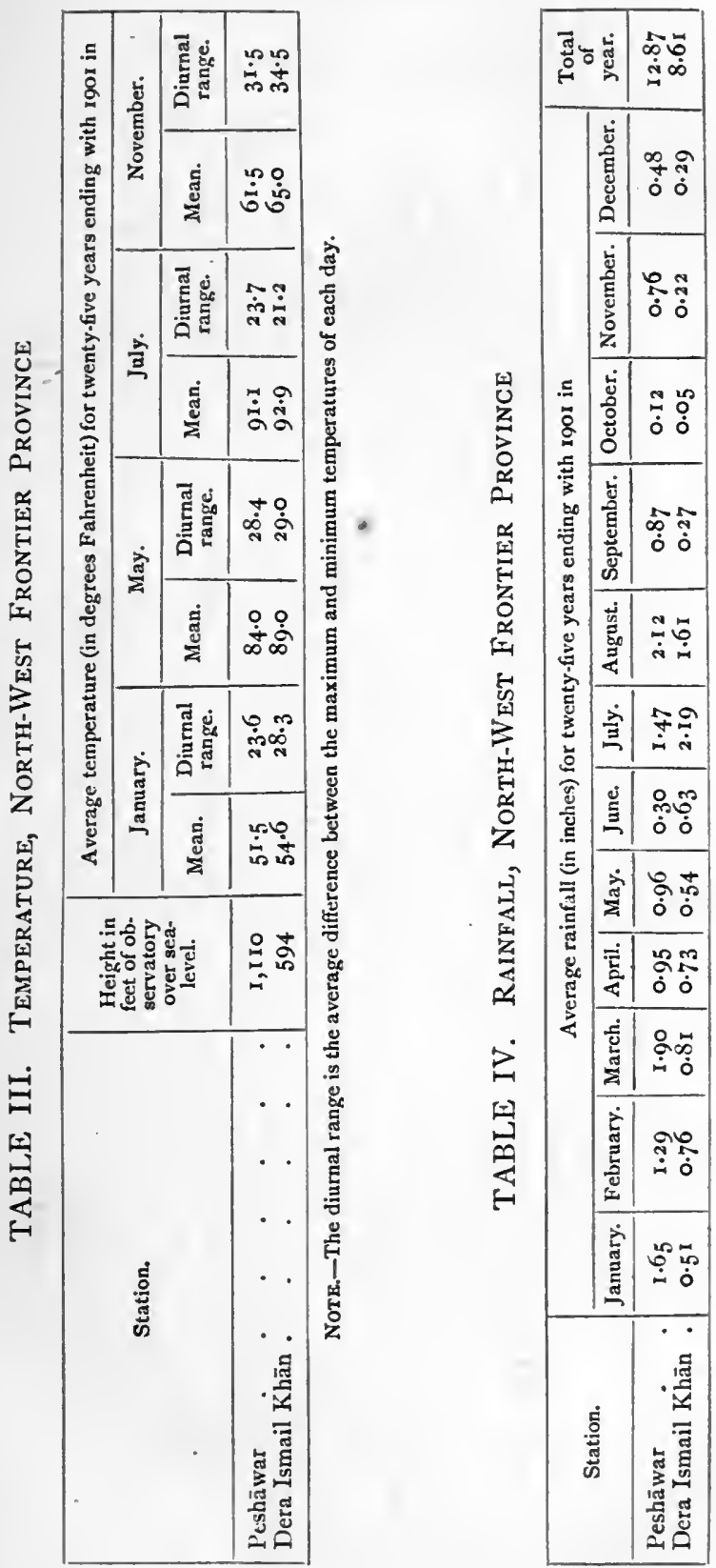


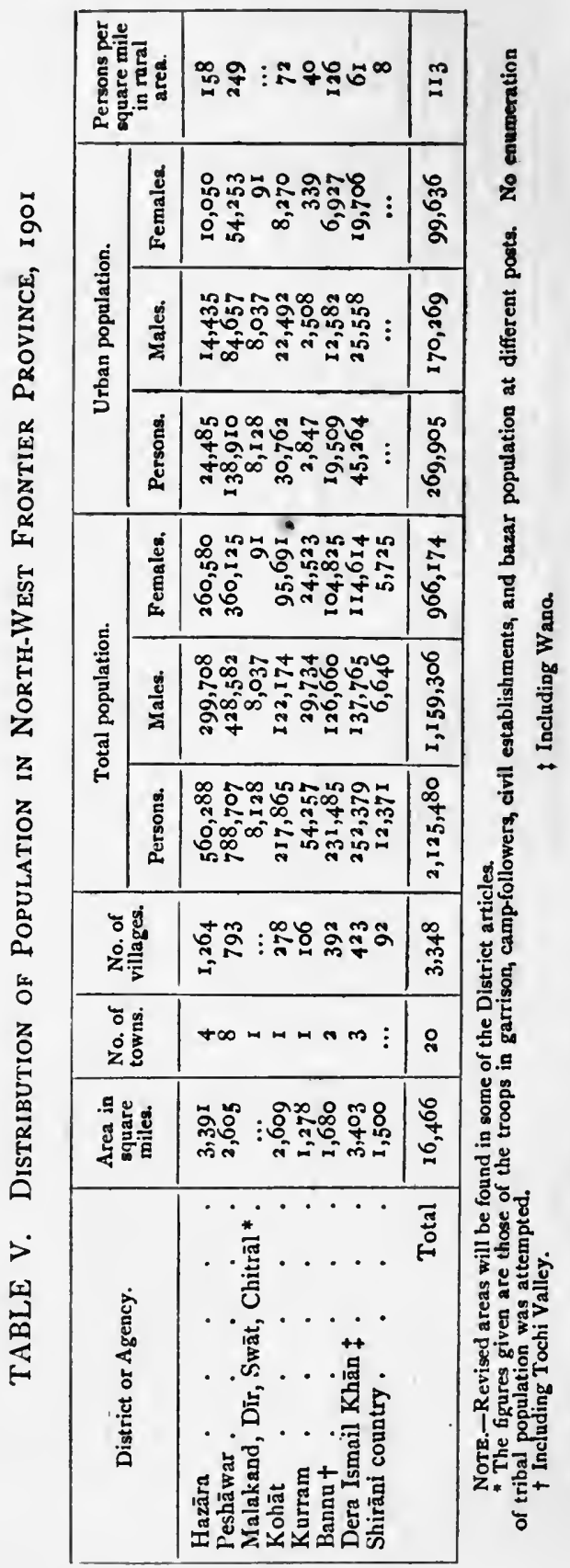




\section{TABLE VI}

Statistics of Agriculture, North-West Frontier Province

(In square miles)

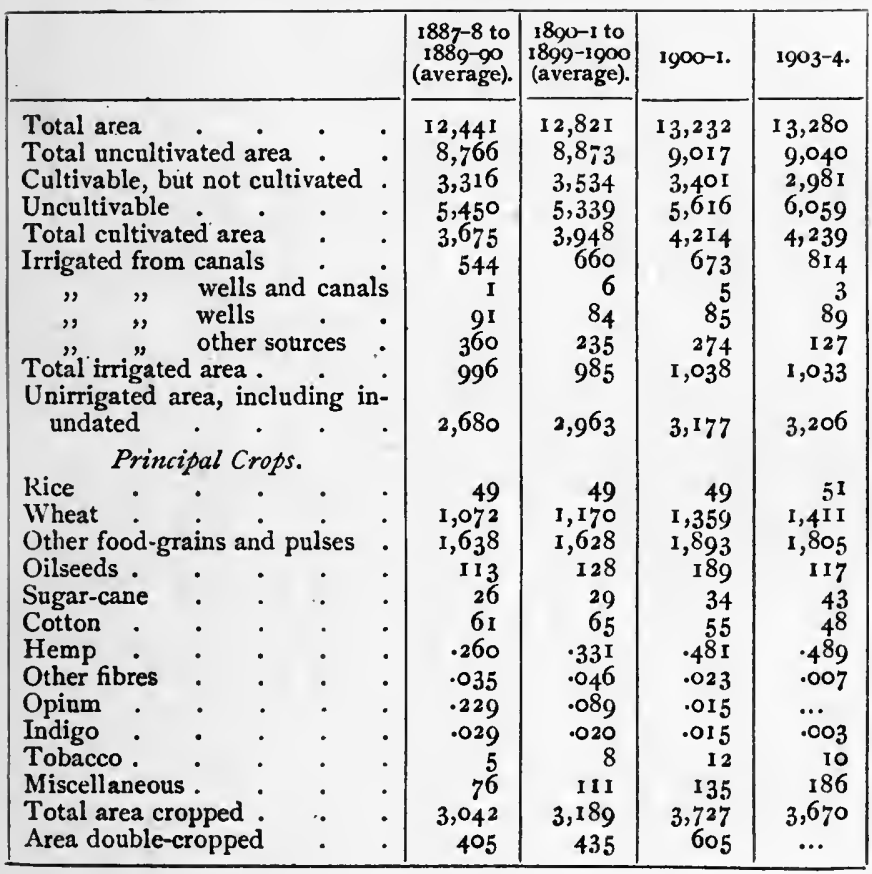




\section{TABLE VII}

Trade of the North-West Frontier Province with other Provinces (including the Punjab) and States IN INDIA

$$
\text { (In thousands of rupees) }
$$

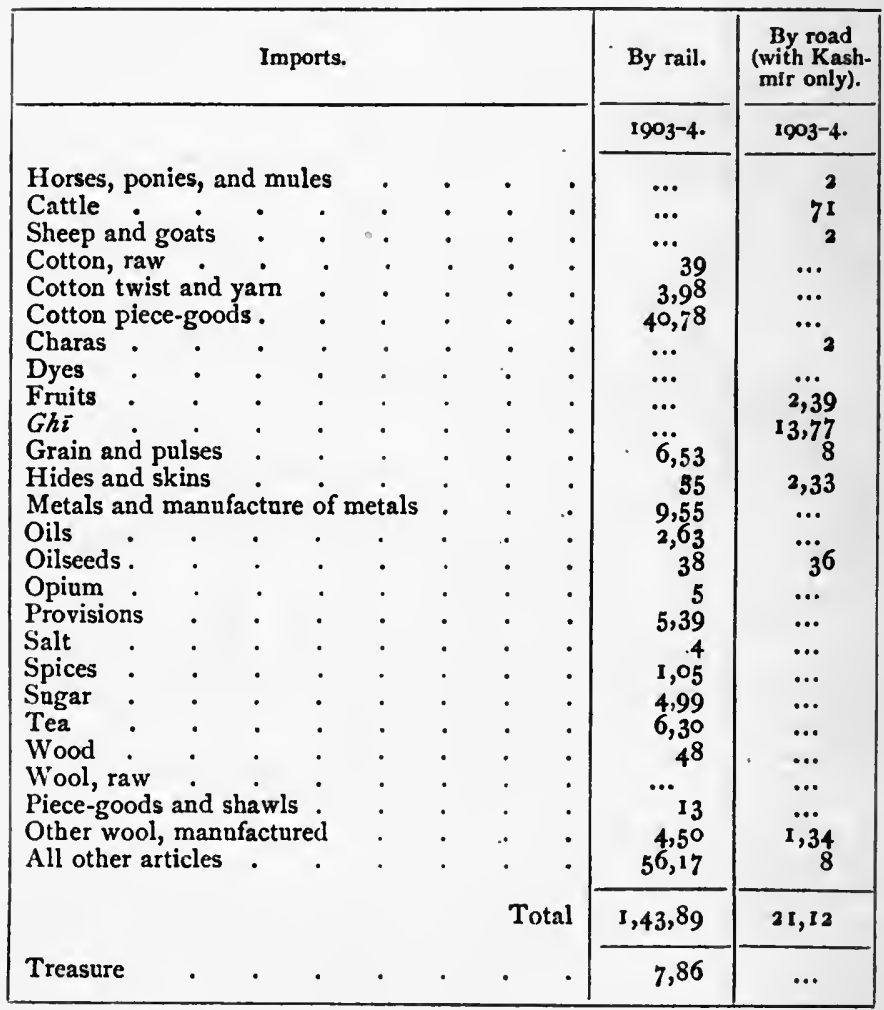


TABLE VII A

Trade of the North-West Frontier Province with COUNTRIES OUTSIDE INDIA

(In thonsands of rupees)

\begin{tabular}{|c|c|c|c|}
\hline & $1890-1$. & $1900-1$ & $1903-4$. \\
\hline & $\begin{array}{c}\text { Including trade } \\
\text { with Kăbul } \\
\text { through Dera } \\
\text { Ghăzi Khăn. }\end{array}$ & \multicolumn{2}{|c|}{$\begin{array}{l}\text { Excluding trade with Kābul } \\
\text { through Dera Ghăzi Khān. }\end{array}$} \\
\hline $\begin{array}{c}\text { Imports. } \\
\text { Total (exclnding treasure) }\end{array}$ & $\begin{array}{r}37,32 \\
7\end{array}$ & $\begin{array}{c}62,5^{1} \\
\ldots\end{array}$ & $\begin{array}{r}65,81 \\
3,14\end{array}$ \\
\hline \multirow{2}{*}{$\begin{array}{l}\text { Treasure } \\
\text { Exports. } \\
\text { Total } \\
\text { Treal (exclnding treasure) } \\
\text { Treasure. }\end{array}$} & 37,39 & 62,51 & 68,95 \\
\hline & $\begin{array}{r}63,27 \\
39\end{array}$ & $\begin{array}{r}\mathrm{I}, 02,3^{8} \\
93\end{array}$ & $\begin{array}{r}1,09,93 \\
5,78\end{array}$ \\
\hline $\begin{array}{ll}\text { Treasure } & \cdot \\
& \text { Total }\end{array}$ & 63,66 & $\mathrm{I}, 03,3 \mathrm{I}$ & $\mathrm{I}, \mathrm{I} 5,7 \mathrm{I}$ \\
\hline
\end{tabular}

\section{TABLE VIII}

Statistics of Criminal Justice, North-West Frontier Province

\begin{tabular}{|c|c|c|c|}
\hline Particulars. & 1901. & 1904 & $\begin{array}{l}\text { Percentage } \\
\text { of con- } \\
\text { victions in } \\
\text { 1904. }\end{array}$ \\
\hline $\begin{array}{l}\text { Number of persons tried :- } \\
\text { (a) For offences against person } \\
\text { and property . } \\
\text { (b) For other offences against the } \\
\text { Indian Penal Code . } \\
\text { (c) For offences against special } \\
\text { and local laws }\end{array}$ & $\begin{array}{r}13,912 \\
3,825 \\
18,696\end{array}$ & $\begin{array}{r}11,074 \\
3,070 \\
13,6_{43}\end{array}$ & $\begin{array}{l}24 \cdot I \\
39 \cdot 0 \\
66 \cdot 5\end{array}$ \\
\hline Total & $3^{6,433}$ & 27,787 & $4^{6.6}$ \\
\hline
\end{tabular}

\section{TABLE IX}

Statistics of Civil Justice, North-West Frontier Province

\begin{tabular}{|c|c|c|c|c|}
\hline \multicolumn{3}{|c|}{ Particulars. } & 1901. & 1904. \\
\hline \multirow{5}{*}{\multicolumn{2}{|c|}{$\begin{array}{l}\text { Suits for money and movable property } \\
\text { Title and other snits. } \\
\text { Rent snits* } \\
\text { Other Revenue Court cases* }\end{array}$}} & \multirow{5}{*}{$\begin{array}{ll} & . \\
. & \\
. & \\
\cdot & \\
\text { Total }\end{array}$} & 14,870 & 16,877 \\
\hline & & & 4,644 & 4,198 \\
\hline & & & $\ldots$ & 5 \\
\hline & & & ... & 3,125 \\
\hline & & & 19,514 & 24,205 \\
\hline
\end{tabular}

\footnotetext{
* Figures for rgor not available.
} 


\section{TABLE X}

\section{Revenue and Expenditure of the North-West Frontier Province}

(In thousands of rupees)

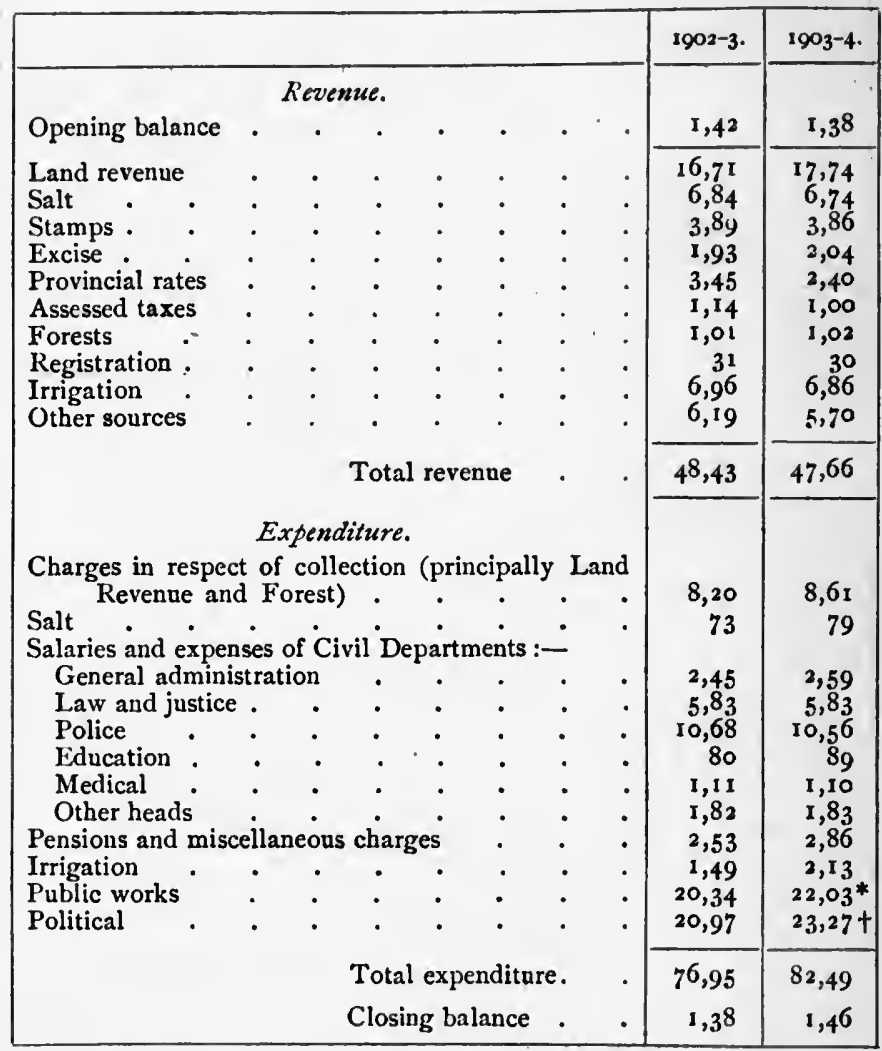

* Of the Rs. 22,03 expended on Public Works, $4^{.21}$ was the cost of buildings, the balance of communications. The most important buildings were the head-quarter offices (2'16 lakhs). Amongst communications the chief works were the MurtazaWana road ( $3^{\circ} 63$ lakhs), roads in the Khyber Agency $\left(2^{*} 1\right.$ lakhs), the cart-road from Kohăt to Peshăwar (1 31 ), Kharmana Bridge $0^{\prime} 52$, Dora Bridge $0 \cdot 84$ lakh.

+ Of the Rs. 23,27,000 devoted to Political expenditure nearly 15 lakhs is on account of the up-keep of Militia, Levy Corps (including the Chitral Scouts, but not the Border Military Police of the British Districts), 4 lakhs represents the cost of the Give Political Agents and their establishments, while 3 lakhs is annually distributed as subsidies to Frontier tribes. The remainder is made up of miscellaneous items, such as rewards for intelligence, entertainment of envoys, allowances to refugees, secret service, \&c. 


\section{TABLE XI}

Income and Expenditure of Municipalities, North-West Frontier Province

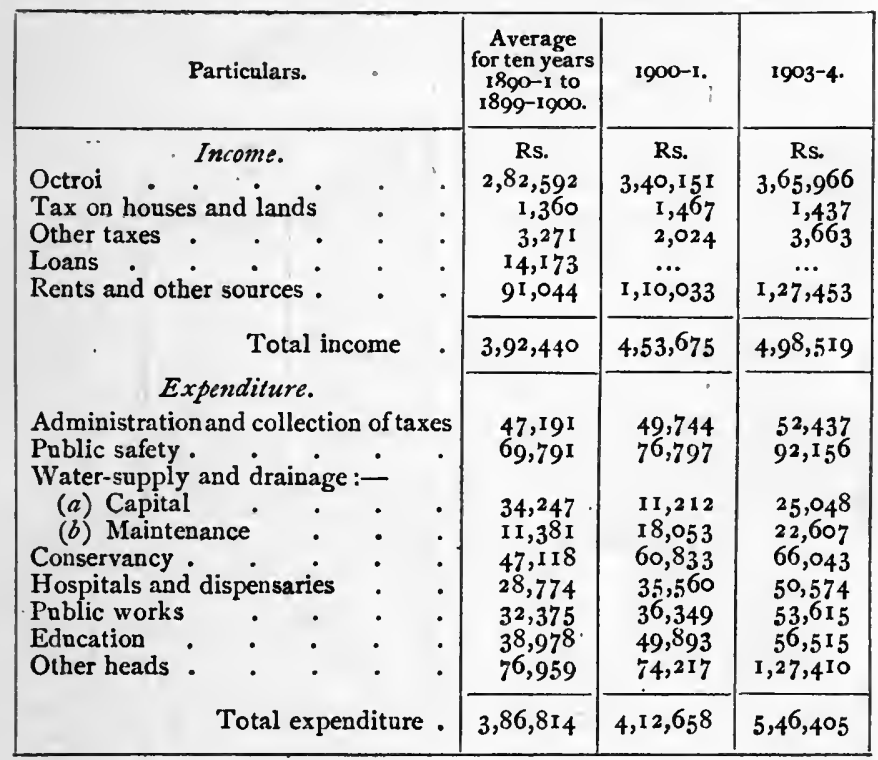


TABLE XII

Income and Expenditure of District Boards, North-West Frontier Province

\begin{tabular}{|c|c|c|c|c|c|c|}
\hline \multirow{2}{*}{\multicolumn{4}{|c|}{ Particulars. }} & \multicolumn{2}{|c|}{$\begin{array}{l}\text { North-West Frontier Pro- } \\
\text { vinces, including the Dis- } \\
\text { trict of Mianwalli in the } \\
\text { Punjab. }\end{array}$} & \multirow{2}{*}{ 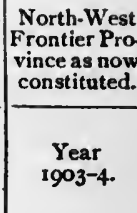 } \\
\hline & & & & $\begin{array}{l}\text { Average for } \\
\text { ten years } \\
1890-1 \text { to } \\
1899-1900 .\end{array}$ & $\begin{array}{c}\text { Year } \\
\text { 1900-1. }\end{array}$ & \\
\hline \multicolumn{4}{|l|}{ Income from- } & Rs. & Rs. & Rs. \\
\hline Provincial rates & . & . & . & $2,04,874$ & $2,16,080$ & $1,54,737$ \\
\hline Interest . & . & . & . & I 5 & 143 & $\begin{array}{c}\ldots \\
.20+1108\end{array}$ \\
\hline Education & . & . & . & $\mathrm{r}, 955$ & 4,701 & 3,833 \\
\hline Medical . & . & . & . & $\mathbf{I}, 937$ & 2,601 & 2,243 \\
\hline Scientific, \&c. & . & . & . & 2,813 & 3,553 & 2,116 \\
\hline Miscellaneous. & . & . & - & 53,574 & 74,058 & 55,191 \\
\hline Civil works & . & . & - & 4,223 & 10,096 & 7,151 \\
\hline Cattle pounds & 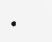 & . & . & 907 & 1,251 & 723 \\
\hline \multicolumn{2}{|c|}{ Total income } & . & - & $2,70,298$ & $3,12,4^{8} 3$ & $2,25,994$ \\
\hline \multicolumn{4}{|l|}{ Expenditure on- } & & & \\
\hline Refunds & & . & - & 228 & & 273 \\
\hline General ac & tion & $0^{\circ}$ & : & $\begin{array}{l}11,856 \\
51,213\end{array}$ & $\begin{array}{l}17,069 \\
60,767\end{array}$ & $\begin{array}{l}15,660 \\
53,610\end{array}$ \\
\hline $\begin{array}{l}\text { Education } \\
\text { Medical . }\end{array}$ & $\dot{.}$ & : & : & 34,242 & 40,195 & 30,967 \\
\hline Scientific, \&c. & . & - & - & 9,683 & I 3,049 & $12,25^{8}$ \\
\hline Miscellaneous & . & 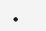 & . & 89,510 & $1,00,905$ & 54,196 \\
\hline Civil works & & & • & 72,572 & 77,865 & 65,644 \\
\hline \multicolumn{3}{|c|}{ Total expenditure } & - & $2,69,304$ & $3,09,85^{2}$ & $2,32,608$ \\
\hline
\end{tabular}




\section{TABLE XIII}

Police Statistics, North-West Frontier Province

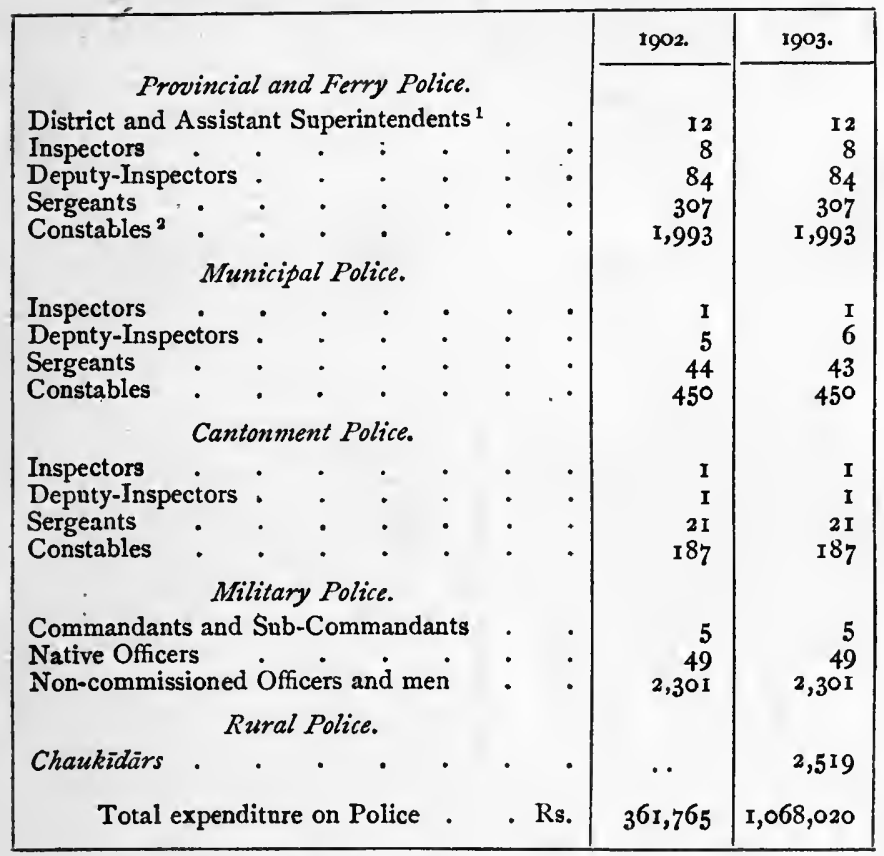

1 Includes officers of the Samana Rifles.

2 Includes monnted constables. 


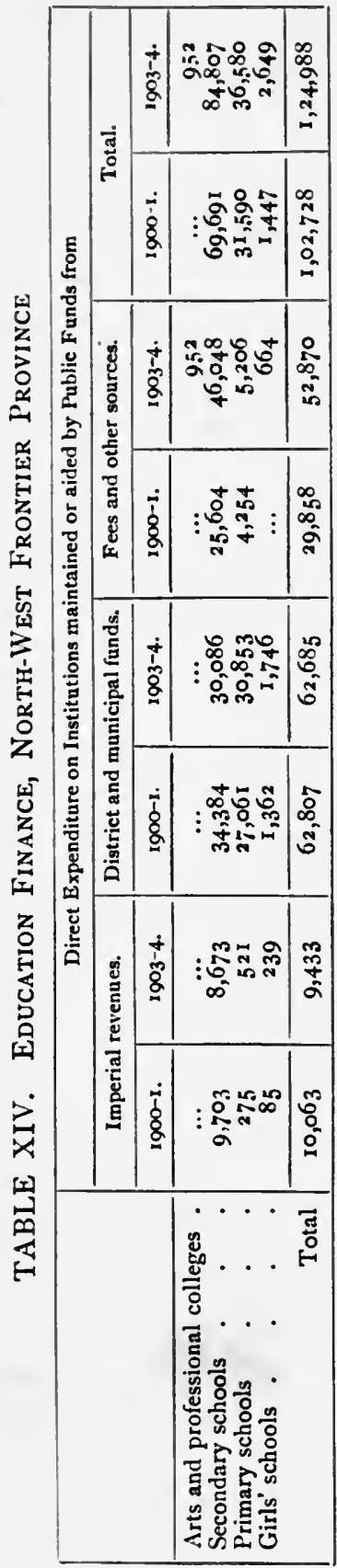

\begin{tabular}{|c|c|c|c|c|}
\hline \multirow{3}{*}{$\frac{1}{8}$} & 若 & $\vdots \quad \vdots::^{20}$ & $\vdots \underset{\pi}{\pi}$ & 禜 \\
\hline & है & 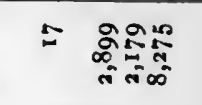 & $\begin{array}{l}\approx \\
\approx \\
\approx \infty\end{array}$ & $\underset{m}{a}$ \\
\hline & 起离 & $-\quad \pm \pm \infty$ & 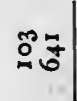 & 웅 \\
\hline \multirow{3}{*}{ 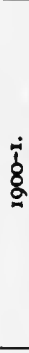 } & 造 & - $\quad \vdots \vdots$ แี & $\vdots \stackrel{m}{\sharp}$ & $\stackrel{0}{0}$ \\
\hline & कू & 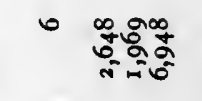 & mo & $\mid \begin{array}{c}0 \\
\vdots \\
\vdots \\
\vdots\end{array}$ \\
\hline & 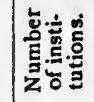 & - 늄요 & $\varnothing \ddot{8}$ & $\stackrel{\infty}{\approx}$ \\
\hline \multirow{3}{*}{ 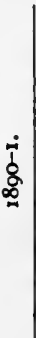 } & \multirow{2}{*}{ 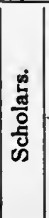 } & $\vdots \quad \vdots \vdots \stackrel{0}{0}$ & $\vdots \vdots$ & 8 \\
\hline & & : & $\vdots \vdots$ & m \\
\hline & 通言高 & : $\quad$ " & $\vdots \vdots$ & $\stackrel{\infty}{=}$ \\
\hline \multirow{3}{*}{$\underset{\mathbf{b}}{\dot{\&}}$} & 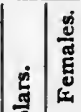 & : & $\vdots: m$ & $\stackrel{\infty}{7}$ \\
\hline &  & $\begin{array}{l}\infty \\
\vdots \\
\infty \\
\infty \\
\infty \\
-1\end{array}$ & 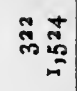 & $\frac{7}{7}$ \\
\hline &  & : & 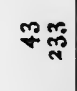 & 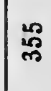 \\
\hline \multicolumn{2}{|r|}{ 莒 } & 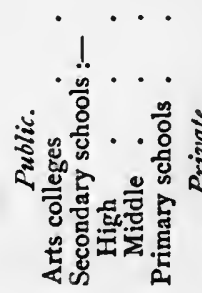 & 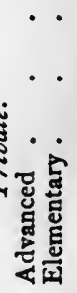 & $\overbrace{0}^{\pi}$ \\
\hline
\end{tabular}




\section{TABLE XV}

Medical Statistics, North-West Frontier Province

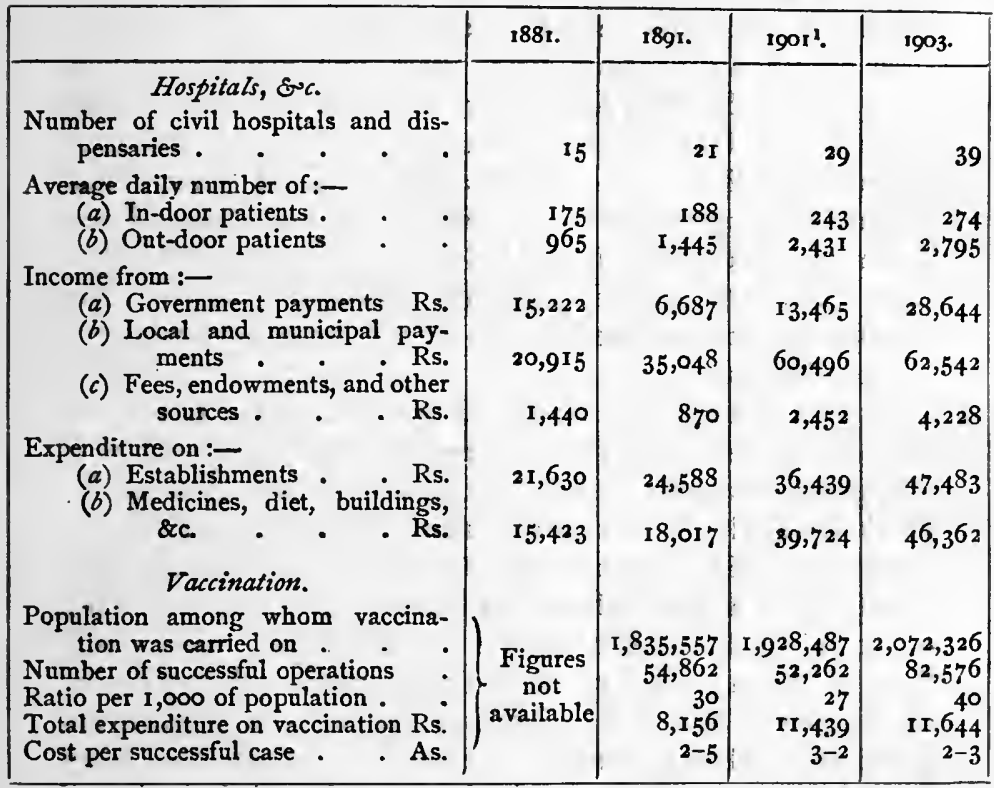

1 Eight Government dispensaries sitnated in Political Agencies sent in no returns in rgor. 


\section{MOUNTAINS, RIVERS, CANALS, AND HISTORIC AREAS}

Himālayas, The.-A system of stupendous mountain ranges, lying along the northern frontiers of the Indian Empire, and containing some of the highest peaks in the Name.! world. Literally, the name is equivalent to 'the abode of snow' (from the Sanskrit hima, 'frost,' and alaya, 'dwellingplace'). To the early geographers the mountains were known as Imaus or Himaus and Hemodas; and there is reason to believe that these names were applied to the western and eastern parts respectively, the sources of the Ganges being taken as the dividing line. 'Hemodas' represents the Sanskrit Himãvata (Prākrit Hemota), meaning 'snowy.' The Greeks who accompanied Alexander styled the mountains the Indian Caucasus.

Extent of Modern writers have sometimes included in the system the range.

Political distribution. Muztāgh range, and its extension the Karakoram; but it is now generally agreed that the Indus should be considered the north-western limit. From the great peak of Nanga Parbat in Kashmir, the Himālayas stretch eastward for twenty degrees of longitude, in a curve which has been compared to the blade of a scimitar, the edge facing the plains of India. Barely onethird of this vast range of mountains is known with any degree of accuracy. The Indian Survey department is primarily engaged in supplying administrative needs; and although every effort is made in fulfilling this duty to collect information of purely scientific interest, much still remains to be done.

A brief abstract of our knowledge of the Himālayas may be given by shortly describing the political divisions of India which include them. On the extreme north-west, more than half of the State of KaSHMir and Jammu lies in the Himallayas, and this portion has been described in some detail by Drew in Jammu and Kashmir Territories, and by Sir W. Lawrence in The Valley of Kashmir. The next section, appertaining to the Punjab and forming the British District of Kangra and the group of feudatories known as the Simla Hill States, is better known. East of this lies the Kumaun Division of the United Provinces, attached to which is the Tehri 
State. This portion has been surveyed in detail, owing to the requirements of the revenue administration, and is also familiar from the careful accounts of travellers. For 500 miles the State of Nepãl occupies the mountains, and is to the present day almost a terra incognita, owing to the acquiescence by the British Government in the policy of exclusion adopted by its rulers. Our knowledge of the topography of this portion of the Himallayas is limited to the information obtained during the operations of 1816 , materials collected by British officials resident at Kātmāndu, notably B. H. Hodgson, and the accounts of native explorers. The eastern border of Nepāl is formed by the State of Sikkim and the Bengal District of Darjeeling, which have been graphically described by Sir Joseph Hooker and more recently by Mr. Douglas Freshfield. A small wedge of Tibetan territory, known as the Chumbi Valley, separates Sikkim from Bhutān, which latter has seldom been visited by Europeans. East of Bhutān the Himālayas are inhabited by savage tribes, with whom no intercourse is possible except in the shape of punitive expeditions following raids on the plains. Thus a stretch of nearly 400 miles in the eastern portion of the range is imperfectly known.

In the western part of the Himālayas, which, as has been Divisions shown, has been more completely examined than elsewhere, the of range. system may be divided into three portions. The central or main axis is the highest, which, starting at Nanga Parbat on the north-west, follows the general direction of the range. Though it contains numerous lofty peaks, including Nandā Devi, the highest mountain in British India, it is not a true watershed. North of it lies another range, here forming the boundary between India and Tibet, which shuts off the valley of the Indus, and thus may be described as a real waterparting. From the central axis, and usually from the peaks in it, spurs diverge, with a general south-easterly or south-westerly direction, but actually winding to a considerable extent. These spurs, which may be called the Outer Himālayas, cease with some abruptness at their southern extremities, so that the general elevation is 8,000 or 9,000 feet a few miles from the plains. Separated from the Outer Himãlayas by elevated valleys or düns is a lower range known as the SiwäLıKs, which is well marked between the Beās and the Ganges, reappears to the south of central Kumaun, and is believed to exist in Nepāl. Although the general character of the Himālayas in Nepāl is less accurately known, there is reason to suppose that it approximates to that of the western ranges. 
Scenery. Within the limits of this great mountain chain all varieties of scenery can be obtained, except the placid charm of level country. Luxuriant vegetation clothes the outer slopes, gradually giving place to more sombre forests. As higher elevations are reached, the very desolation of the landscape affects the imagination even more than the beautiful scenery left behind. It is not surprising that these massive peaks are venerated by the Hindus, and are intimately connected with their religion, as giving rise to some of the most sacred rivers, as well as on account of legendary associations. A recent writer has vividly described the impressions of a traveller through the foreground of a journey to the snows in Sikkim ' :-

'He sees at one glance the shadowy valleys from which shining mist-columns rise at noon against a luminous sky, the forest ridges, stretching fold behind fold in softly undulating lines-dotted by the white specks which mark the situation of Buddhist monasteries - to the glacier-draped pinnacles and precipices of the snowy range. He passes from the zone of tree-ferns, bamboos, orange-groves, and $d a l$ forest, through an endless colonnade of tall-stemmed magnolias, oaks, and chestnut trees, fringed with delicate orchids and festooned by long convolvuluses, to the region of gigantic pines, junipers, firs, and larches. Down each ravine sparkles a brimming torrent, making the ferns and flowers nod as it dashes past them. Superb butterflies, black and blue, or flashes of rainbow colours that turn at pleasure into exact imitations of dead leaves, the fairies of this lavish transformation scene of Nature, sail in and out between the sunlight and the gloom. The mountaineer pushes on by a track half buried between the red twisted stems of tree-rhododendrons, hung with long waving lichens, till he emerges at last on open sky and the upper pastures-the Alps of the Himālaya-fields of flowers : of gentians and edelweiss and poppies, which blossom beneath the shining storehouses of snow that encompass the ice-mailed and fluted shoulders of the giants of the range. If there are mountains in the world which combine as many beauties as the Sikkim Himālayas, no traveller has as yet discovered and described them for us.'

Snow-line. The line of perpetual snow varies from 15,000 to 16,000 feet on the southern exposures. In winter, snow generally falls at elevations above 5,000 feet in the west, while falls at 2,500 feet were twice recorded in Kumaun during the last century. Glaciers extend below the region of perpetual snow, descending to 12,000 or 13,000 feet in Kulū and Lāhul, and even lower in Kumaun, while in Sikkim they are about 2,000 feet

${ }^{1}$ D. W. Freshfield in The Geographical Journal, vol. xix, p. 453. 
higher. On the vast store-house thus formed largely depends the prosperity of Northern India, for the great rivers which derive their water from the Himālayas have a perpetual supply which may diminish in years of drought, but cannot fail absolutely to feed the system of canals drawn from them.

While all five rivers from which the Punjab derives its Rivers. name rise in the Himālayas, the Sutlej alone has its source beyond the northern range, near the head-waters of the Indus and Tsan-po. In the next section are found the sources of the Jumna, Ganges, and Kālī or Sārdā high up in the central snowy range, while the Kauriāla or Karnāli, known lower down in its course as the Gogra, rises in Tibet, beyond the northern watershed. The chief rivers of Nepāl, the Gandak and Kosi, each with seven main affluents, have their birth in the Himālayas, which here supply a number of smaller streams merging in the larger rivers soon after they reach the plains. Little is known of the upper courses of the northern tributaries of the Brahmaputra in Assam; but it seems probable that the Dihāng, which has been taken as the eastern boundary of the Himālayas, is the channel connecting the Tsan-po and the Brahmaputra.

Passing from east to west the principal peaks are Nanga Highest Parbat $(26,182)$ in Kashmir ; a peak in Spiti (Kāngra District) peaks. exceeding 23,000 feet, besides three over 20,000; Nandā Devī (25,66r), Trisūl $(23,382)$, Pānch Chūlhī $(22,673)$, and Nandã Kot $\left(22,53^{8}\right)$ in the United Provinces; Mount Everest (29,002), Devālagiri $(26,826)$, Gosainthān $(26,305)$ and Kinchinjunga $(28,146)$, with several smaller peaks, in Nepāl ; and Dongkya $(23,190)$, with a few rising above 20,000 , in Sikkim.

The most considerable stretch of level ground is the Valleys beautiful Kashmir Valley, through which flows the Jhelum. and lakes. In length about 84 miles, it has a breadth varying from 20 to 25 miles. Elsewhere steep ridges and comparatively narrow gorges are the rule, the chief exception being the Valley of Nepāl, which is an undulating plain about 20 miles from north to south, and 12 to 14 miles in width. Near the city of Srinagar is the Dal Lake, described as one of the most picturesque in the world. Though measuring only 4 miles by $2 \frac{1}{2}$, its situation among the mountains, and the natural beauty of its banks, combined with the endeavours of the Mughal emperors to embellish it, unite to form a scene of great attraction. Some miles away is the larger expanse of water known as the Wular Lake, which ordinarily covers I $2 \frac{1}{2}$ square miles, but in years of flood expands to over roo. A number of smaller 
lakes, some of considerable beauty, are situated in the outer ranges in Naini Tãl District. In 1903 the GoHNĀ LAKE, in Garhwāl District, was formed by the subsidence of a steep hill, rising 4,000 feet above the level of a stream which it blocked.

Geology'. The geological features of the Himàlayas can be conveniently grouped into three classes, roughly corresponding to the three main orographical zones: ( $\mathrm{r}$ ) the Tibetan highland zone, (2) the zone of snowy peaks and Outer Himālayas, and (3) the Sub-Himālayas.

In the Tibetan highlands there is a fine display of marine fossiliferous rocks, ranging in age from Lower Palaeozoic to Tertiary. In the zone of the snowy peaks granites and crystalline schists are displayed, fringed by a mantle of unfossiliferous rocks of old, but generally unknown, age, forming the lower hills or Outer Himālayas, while in the Sub-Himālayas the rocks are practically all of Tertiary age, and are derived from the waste of the highlands to the north.

Age and origin of the range.
The disposition of these rocks indicates the existence of a range of some sort since Lower Palaeozoic times, and shows that the present southern boundary of the marine strata on the northern side of the crystalline axis is not far from the original shore of the ocean in which these strata were laid down. The older unfossiliferous rocks of the Lower Himallayas on the southern side of the main crystalline axis are more nearly in agreement with the rocks which have been preserved without disturbance in the Indian Peninsula; and even remains of the great Gondwāna river-formations which include our valuable deposits of coal are found in the Darjeeling area, involved in the folding movements which in later geological times raised the Himālayas to be the greatest among the mountain ranges of the world. The Himālayas were thus marked out in very early times, but the main folding took place in the Tertiary era. The great outflow of the Deccan trap was followed by a depression of the area to the north and west, the sea in eocene times spreading itself over Rājputāna and the Indus valley, covering the Punjab to the foot of the Outer Himãlayas as far east as the Ganges, at the same time invading on the east the area now occupied by Assam. Then followed a rise of the land and consequent retreat of the sea, the fresh-water deposits which covered the eocene marine strata being involved in the movement as fast as they were formed, until the SubHimālayan zone river-deposits, no older than the pliocene,

1 By T. H. Holland, Geological Survey of India. 
became tilted up and even overturned in the great foldings of the strata. This final rise of the Himãlayan range in late Tertiary times was accompanied by the movements which gave rise to the Arakan Yoma and the Nāgā hills on the east, and the hills of Baluchistān and Afghānistān on the west.

The rise of the Himālayan range may be regarded as a great buckle in the earth's crust, which raised the great Central Asian plateau in late Tertiary times, folding over in the Baikal region on the north against the solid mass of Siberia, and curling over as a great wave on the south against the firmly resisting mass of the Indian Peninsula.

As an index to the magnitude of this movement within the Tertiary era, we find the marine fossil foraminifer, Nummulites, which lived in eocene times in the ocean, now at elevations of 20,000 feet above sea-level in Zāskār. With the rise of the Himālayan belt, there occurred a depression at its southern foot, into which the alluvial material brought down from the hills has been dropped by the rivers. In miocene times, when presumably the Himālayas did not possess their present elevation, the rivers deposited fine sands and clays in this area; and as the elevatory process went on, these deposits became tilted up, while the rivers, attaining greater velocity with their increased gradient, brought down coarser material and formed conglomerates in pliocene times. These also became elevated and cut into by their own rivers, which are still working along their old courses, bringing down boulders to be deposited at the foot of the hills and carrying out the finer material farther over the Indo-Gangetic plain.

The series of rocks which have thus been formed by the The rivers, and afterwards raised to form the Sub-Himālayas, are Siwālik known as the Siwālik series. They are divisible into three stages. In the lowest and oldest, distinguished as the Nāhan stage, the rocks are fine sandstones and red clays without any pebbles. In the middle stage, strings of pebbles are found with the sandstones, and these become more abundant towards the top, until we reach the conglomerates of the upper stage. Along the whole length of the Himālayas these Siwālik rocks are cut off from the older rock systems of the higher hills by a great reversed fault, which started in early Siwālik times and developed as the folding movements raised the mountains and involved in its rise the deposits formed along the foot of the range. The Siwallik strata never extended north of this great boundary fault, but the continued rise of the mountains affected 
these deposits, and raised them up to form the outermost zone of hills.

The upper stage of the Siwalik series is famous on account of the rich collection of fossil vertebrates which it contains. Among these there are forms related to the miocene mammals of Europe, some of which, like the hippopotamus, are now unknown in India but have relatives in Africa. Many of the mammals now characteristic of India were represented by individuals of much greater size and variety of species in Siwālik times.

Unfossil- The unfossiliferous rocks which form the Outer Himālayas iferous rocks of Onter Himālayas. are of unknown age, and may possibly belong in part to the unfossiliferous rocks of the Peninsula, like the Vindhyans and the Cuddapahs. Conspicuous among these rocks are the dolomitic limestones of Jaunsār and Kumaun, the probable equivalents of the similar rocks far away to the east at Buxa in the Duarrs. With these a series of purple quartzites and basic lava-flow is often associated. In the Simla area the unfossiliferous rocks have been traced out with considerable detail ; and $i t$ has been shown that quartzites, like those of Jaunsār and Kumaun, are overlaid by a system of rocks which has been referred to the carbonaceous system on account of the black carbonaceous slates which it includes. The only example known of pre-Tertiary fossiliferous rocks south of the snowy range in the Himālayas occurs in south-west Garhwāl, where there are a few fragmentary remains of mesozoic fossils of marine origin.

The crys- The granite rocks, which form the core of the snowy range talline axis. and in places occur also in the Lower Himālayas, are igneous rocks which may have been intruded at different periods in the history of the range. They are fringed with crystalline schists, in which a progressive metamorphism is shown from the edge of granitic rock outwards, and in the inner zone the granitic material and the pre-existing sedimentary rock have become so intimately mixed that a typical banded gneiss is produced. The resemblance of these gneisses to the well-known gneisses of Archaean age in the Peninsula and in other parts of the world led earlier observers to suppose that the gneissose rocks of the Central Himālayas formed an Archaean core, against which the sediments were subsequently laid down. But as we now know for certain that both granites, such as we have in the Himālayas, and banded gneisses may be much younger, even Tertiary in age, the mere composition and structure give no clue to the age of the crystalline axis. The position of the 
granite rock is probably dependent on the development of lowpressure areas during the process of folding, and there is thus a prima facie reason for supposing that much of the igneous material became injected during the Tertiary period. With the younger intrusions, however, there are probably remains of injections which occurred during the more ancient movements, and there may even be traces of the very ancient Archaean gneisses; for we know that pebbles of gneisses occur in the Cambrian conglomerates of the Tibetan zone, and these imply the existence of gneissose rocks exposed to the atmosphere in neighbouring highlands. The gneissose granite of the Central Himālayas must have consolidated under great pressure, with a thick superincumbent envelope of sedimentary strata ; and their exposure to the atmosphere thus implies a long period of effectual erosion by weathering agents, which have cut down the softer sediments more easily and left the more resisting masses of crystalline rocks to form the highest peaks in the range. Excellent illustrations of the relationship of the gneissose granites to the rocks into which they have been intruded are displayed in the Dhaola Dhār in Kulū, in the Chor Peak in Garhwāl, and in the Darjeeling region east of Nepāl.

Beyond the snowy range in the Tibetan zone we have a Fossilremarkable display of fossiliferous rocks, which alone would iferous have been enough to make the Himãlayas famous in the rocks of geological world. The boundary between Tibetan territory tan zone. and Spiti and Kumaun has been the area most exhaustively studied by the Geological Survey. The rocks exposed in this zone include deposits which range in age from Cambrian to Tertiary. The oldest fossiliferous system, distinguished as the Haimanta ('snow-covered') system, includes some 3,000 feet of the usual sedimentary types, with fragmentary fossils which indicate Cambrian and Silurian affinities. Above this system there are representatives of the Devonian and Carboniferous of Europe, followed by a conglomerate which marks a great stratigraphical break at the beginning of Permian times in Northern India. Above the conglomerate comes one of the most remarkably complete succession of sediments known, ranging from Permian, without a sign of disturbance in the process of sedimentation, throughout the whole Mesozoic epoch to the beginning of Tertiary times. The highly fossiliferous character of some of the formations in this great pile of strata, like the Productus shales and the Spiti shales, has made this area classic ground to the palaeontologist.

The great Eurasian sea distinguished by the name 'Thetys,' 
which spread over this area throughout the Palaeozoic and Mesozoic times, became driven back by the physical revolution which began early in Tertiary times, when the folding movements gave rise to the modern Himālayas. As relics of this ocean have been discovered in Burma and China it will not be surprising to find, when the ground is more thoroughly explored, that highly fossiliferous rocks are preserved also in the Tibetan zone beyond the snowy ranges of Nepal and Sikkim.

Economic minerals.

Of the minerals of value, graphite has been recorded in the Kumaun Division; coal occurs frequently amongst the Nummulitic (eocene) rocks of the foot-hills and the Gondwāna strata of Darjeeling District; bitumen has been found in small quantities in Kumaun; stibnite, a sulphide of antimony, occurs associated with ores of zinc and lead in well-defined lodes in Lāhul; gold is obtained in most of the rivers, and affords a small and precarious living for a few washers ; copper occurs very widely disseminated and sometimes forms distinct lodes of value in the slaty series south of the snowy range, as in the Kulū, Kumaun, and Darjeeling areas; ferruginous schists sometimes rich in iron occur under similar geological conditions, as in Kāngra and Kumaun; sapphires of considerable value have been obtained in Zāskār and turquoises from the central highlands; salt is being mined in quantity from near the boundary of the Tertiary and older rocks in the State of Mandi; borax and salt are obtained from lakes beyond the Tibetan border; slate-quarrying is a flourishing industry along the southern slopes of the Dhaola Dhār in Kāngra District; mica of poor quality is extracted from the pegmatites of Kulũ ; and a few other minerals of little value, besides building-stones, are obtained in various places. A small trade is developed, too, by selling the fossils from the Spiti shales as sacred objects.

Botany. The general features of the great variety in vegetation have been illustrated in the quotation from Mr. Freshfield's description of Sikkim. These variations are naturally due to an increase in elevation, and to the decrease in rainfall and humidity passing from south to north, and from east to west. The tropical zone of dense forest extends up to about 6,500 feet in the east, and 5,000 feet in the west. In the Eastern Himālayas orchids are numerically the predominant order of flowering plants; while in Kumaun about 62 species, both epiphytic and terrestrial, have been found. A temperate zone succeeds, ranging to about 12,000 feet, in which oaks, pines, and tree-rhododendrons are conspicuous, with chestnut, maple, magnolia, and laurel in the east. Where rain and mist are not 
excessive, as for example in Kulū and Kumaun, European fruit trees (apples, pears, apricots, and peaches) have been naturalized very successfully, and an important crop of potatoes is obtained in the west. Above about 12,000 feet the forests become thinner. Birch and willow mixed with dwarf rhododendrons continue for a time, till the open pasture land is reached, which is richly adorned in the summer months with brilliant Alpine species of flowers. Contrasting the western with the eastern section we find that the former is far less rich, though it has been better explored, while there is a preponderance of European species. A fuller account of the botanical features of the Himālayas will be found in Vol. I, chap. iv.

To obtain a general idea of the fauna of the Himālayas it is Fauna. sufficient to consider the whole system as divided into two tracts : namely, the area in the lower hills where forests can flourish, and the area above the forests. The main characteristics of these tracts have been summarized by the late Dr. W. T. Blanford ${ }^{1}$. In the forest area the fauna differs markedly from that of the Indian Peninsula stretching away from the base of the hills. It does not contain the so-called Aryan element of mammals, birds, and reptiles which are related to Ethiopian and Holarctic genera, and to the pliocene Siwālik fauna, nor does it include the Dravidian element of reptiles and batrachians. On the other hand, it includes the following animals which do not occur in the Peninsula-Mammals : the families Simiidae, Procyonidae, Talpidae, and Spalacidae, and the sub-family Gymnurinae, besides numerous genera, such as Prionodon, Helictis, Arctonyx, Atherura, Nemorhaedus, and Cemas. Birds: the families Eurylaemidae, Indicatoridae, and Heliornithidae, and the sub-family Paradoxornithinae. Reptiles: Platysternidae and Anguidae. Batrachians: Dyscophidae, Hylidae, Pelobatidae, and Salamandridae. Compared with the Peninsula, the fauna of the forest area is poor in reptiles and batrachians.

'It also contains but few peculiar genera of mammals and birds, and almost all the peculiar types that do occur have Holarctic affinities. The Oriental element in the fauna is very richly represented in the Eastern Himālayas and gradually diminishes to the westward, until in Kashmir and farther west it ceases to be the principal constituent. 'These facts are consistent with the theory that the Oriental constituent of the Himālayan fauna, or the greater portion of it, has migrated into the mountains from the eastward at a comparatively

1 'The Distribution of Vertebrate Animals in India, Ceylon and Burma,' Proceedings, Royal Society, vol. lxvii, p. 484 . 
recent period. It is an important fact that this migration appears to have been from Assam and not from the Peninsula of India.'

Dr. Blanford suggested that the explanation was to be found in the conditions of the glacial epoch. When the spread of snow and ice took place, the tropical fauna, which may at that time have resembled more closely that of the Peninsula, was forced to retreat to the base of the mountains or perished. At such a time the refuge afforded by the Assam Valley and the hill ranges south of it, with their damp, sheltered, forestclad valleys, would be more secure than the open plains of Northern India and the drier hills of the country south of these. As the cold epoch passed away, the Oriental fauna re-entered the Himallayas from the east.

Above the forests the Himalayas belong to the Tibetan sub-region of the Holarctic region, and the fauna differs from that of the Indo-Malay region, 44 per cent. of the genera recorded from the Tibetan tract not being found in the IndoMalay region. During the glacial epoch the Holarctic forms apparently survived in great numbers.

People. Owing to the rugged nature of the country, which makes travelling difficult and does not invite immigrants, the inhabitants of the Himālayas present a variety of ethnical types which can hardly be summarized briefly. Two common features extending over a large area may be referred to. From Ladākh in Kashmīr to Bhutān are found races of IndoChinese type, speaking dialects akin to Tibetan and professing Buddhism. In the west these features are confined to the higher ranges; but in Sikkim, Darjeeling, and Bhutān they are found much nearer the plains of India. Excluding Burma, this tract of the Himallayas is the only portion of India in which Buddhism is a living religion. As in Tibet, it is largely tinged by the older animistic beliefs of the people. Although the Muhammadans made various determined efforts to conquer the hills, they were generally unsuccessful, yielding rather to the difficulties of transport and climate than to the forces brought against them by the scanty though brave population of the hills. In the twelfth century a Tartar horde invaded Kashmir, but succumbed to the rigours of the snowy passes. Subsequently a Tibetan soldier of fortune seized the supreme power and embraced Islām. Late in the fourteenth century the Muhammadan ruler of the country, Sultān Sikandar, pressed his religion by force on the people, and in the province of Kashmir proper 94 per cent. of the total are now 
Muhammadans. Baltistān is also inhabited chiefly by Muhammadans, but the proportion is much less in Jammu, and beyond the Kashmir State Isläm has few followers. Hinduism becomes an important religion in Jammu, and is predominant in the southern portions of the Himālayas within the Punjab and the United Provinces. It is the religion of the ruling dynasty in Nepäl, where, however, Buddhism is of almost equal strength. East of Nepãl Hindus are few. Where Hinduism prevails, the language in common use, known as Pahāri, presents a strong likeness to the languages of Rājputāna, thus confirming the traditions of the higher classes that their ancestors migrated from the plains of India. In Nepāl the languages spoken are more varied, and Newāri, the ancient state language, is akin to Tibetan. The Mongolian element in the population is strongly marked in the east, but towards the west has been pushed back into the higher portion of the ranges. In Kumaun are found a few shy people living in the recesses of the jungles, and having little intercourse with their more civilized neighbours. Tribes which appear to be akin to these are found in Nepall, but little is known about them. North of Assam the people are of Tibeto-Burman origin, and are styled, passing from west to east, the Akās, Daflās, Mīris, and Abors, the last name signifying 'unknown savages.' Colonel Dalton has described these people in his Ethnology of Bengal.

From the commercial point of view the agricultural products Agriculof the Himālayas, with few exceptions, are of little importance. ture. The chief food-grains cultivated are, in the outer ranges, rice, wheat, barley, maruā, and amaranth. In the hot, moist valleys, chillies, turmeric, and ginger are grown. At higher levels potatoes have become an important crop in Kumaun; and, as already mentioned, in Kulū and Kumaun European fruits have been successfully naturalized, including apples, pears, cherries, and strawberries. Two crops are obtained in the lower hills ; but cultivation is attended by enormous difficulties, owing to the necessity of terracing and clearing land of stones, while irrigation is only practicable by long channels winding along the hill-sides from the nearest suitable stream or spring. As the snowy ranges are approached wheat and buckwheat, grown during the summer months, are the principal crops, and only one harvest in the year can be obtained. Tea gardens were successfully established in Kumaun during the first half of the nineteenth century, but the most important gardens are now situated in Kängra and Darjeeling. In the latter District 
cinchona is grown for the manufacture of quinine and cinchona febrifuge.

Forests. The most valuable forests are found in the Outer Himālayas, yielding a number of timber trees, among which may be mentioned sāl, shisham (Dalbergia Sissoo), and tün(Cedrela Toona). Higher up are found the deodār and various kinds of pine, which are also extracted wherever means of transport can be devised. In the Eastern Himālayas wild rubber is collected by the hill tribes already mentioned, and brought for sale to the Districts of the Assam Valley.

Means of communication.
Communications within the hills are naturally difficult. Railways have hitherto been constructed only to three places in the outer hills : Jammu in the Kashmir State, Simla in the Punjab, and Darjeeling in Bengal. Owing to the steepness of the hillsides and the instability of the strata composing them, these lines have been costly to build and maintain. A more ambitious project is now being carried out to connect the Kashmir Valley with the plains, motive power being supplied by electricity to be generated by the Jhelum river. The principal road practicable for wheeled traffic is also in Kashmir, leading from Rāwalpindi in the plains through Murree and Bāramūla to Srinagar. Other cart-roads have been made connecting with the plains the hill stations of Dharmsāla, Simla, Chakrāta, Mussoorie, Dalhousie, Nainī Tāl, and Rānikhet. In the interior the roads are merely bridle paths. The great rivers flowing in deep gorges are crossed by suspension bridges made of the rudest materials. The sides consist of canes and twisted fibres, and the footway may be a single bamboo laid on horizontal canes supported by ropes attached to the sides. These frail constructions, oscillating from side to side under the tread of the traveller, are crossed with perfect confidence by the natives, even when bearing heavy loads. On the more frequented paths, such as the pilgrim road from Hardwār up the valley of the Ganges to the holy shrines of Badrinath and Kedārnāth, more substantial bridges have been constructed by Government, and the roads are regularly repaired. Sheep and, in the higher tracts, yaks and crosses between the yak and ordinary cattle are used as beasts of burden. The trade with Tibet is carried over lofty passes, the difficulties of which have not yet been ameliorated by engineers. Among these the following may be mentioned: the Kangwa $\mathrm{La} \mathrm{(15,500}$ feet) on the Hindustān-Tibet road through Simla ; the Mānā ( 18,000 feet), Nitī (16,570 feet), and Balcha Dhurā in Garhwāl ; the Anta Dhurā (1 7,270 feet), Lampiya Dhurā (18,000 feet), 


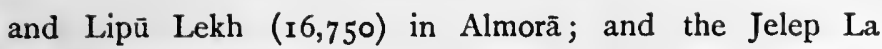
$(r 4,390)$ in Sikkim.

[More detailed information about the various portions of Bibliothe Himalāyas will be found in the articles on the political graphy. divisions referred to above. An admirable summary of the orography of the Himālayas is contained in Lieut.-Col. H. H. Godwin Austen's presidential address to the Geographical Section of the British Association in $188_{3}$ (Proceedings, Royal Geographical Society, 1883, p. 6ro; and 1884, pp. 83 and II 2, with a map). Fuller accounts of the botany, geology, and fauna are given in E. F. Atkinson's Gazetteer of the Himalayan Districts in the North-Western [United] Provinces, 3 vols. (I882-6). See also General Strachey's 'Narrative of a Journey to Mānasarowar,' Geographical Journal, vol. xv, p. 150. More recent works are the Kangra District Gazetteer (Lahore, 1899) ; C. A. Sherring, Western Tibet and the British Borderland (1906); and D. W. Freshfield, Round Kangchenjunga (1903), which contains a full bibliography for the Eastern Himallayas. An account of the Himalayas by officers of the Survey of India and the Geological department is under preparation.]

Black Mountain.-A mountain range on the north-western border of Hazāra District, North-West Frontier Province, lying between $34^{\circ} 32^{\prime}$ and $34^{\circ} 50^{\prime} \mathrm{N}$. and $72^{\circ} 48^{\prime}$ and $72^{\circ} 5^{\prime} \mathrm{E}$. Bounded on the east by Agror and on the south by Tanãwal, the range has a length of 25 to 30 miles from north to south and an elevation of 8,000 feet above sea-level. The Indus washes its northern extremity and thence turns due south. Between the river and the crest of the range the western slopes are occupied by Yūsufzai Pathanns. The rest of the range is held by Swātis, or tribes who have been gradually driven from Swāt by the Yũsufzai. The Black Mountain forms a long, narrow ridge, with higher peaks at intervals and occasional deep passes. Numerous spurs project from its sides, forming narrow gorges in which lie the villages of the tribes. The upper parts of the ridge and spurs are covered with thick forests of pine, oak, sycamore, horse-chestnut, and wild cherry; but the slopes are stony and barren. In $185 \mathrm{r}$ the Hasanzai sept of the Yūsufzai murdered two officers of the British Customs (Salt) department within the borders of Tanāwal. Punishment for this outrage was inflicted by an expedition under Colonel Mackeson, which destroyed a number of tribal strongholds. In I 868 the Yūsufzai, instigated by the Khān of Agror, who resented the establishment of the police post at 
Oghi in the Agror valley, attacked that post in force, but were repulsed. Further attacks on the troops of the Khān of Tanāwal, who remained loyal, followed, and soon culminated in a general advance of the Black Mountain tribes against the British position. This was repulsed, but not until twenty-one British villages had been burnt, and a second expedition under General Wilde had overrun the Black Mountain and secured the full submission of the tribes. In consequence of raids committed in the Agror valley by the Hasanzai and Akazai aided by the Madda Khel, a blockade was commenced in the year r888. While more stringent measures were being organized, Major Battye and Captain Urmston and some sepoys of the $5^{\text {th }}$ Gurkhas were surprised and killed by Güjar dependants of the Akazai. Hāshim Alī, the head of the Hasanzai and Akazai, was suspected of having instigated the crime. An expedition was sent in the same year, with the result that the tribes paid the fines imposed upon them, and agreed to the removal of Hāshim Ali from the Black Mountain and the appointment in his place of his near relative and enemy Ibrāhim Khān. In 1890 the tribe opposed the march of troops along the crest of the Black Mountain, and an expedition was sent against them in the spring of $189 \mathrm{x}$. Immediately after the withdrawal of the troops, the Hindustannis (see AmbELA) and Madda Khel broke their agreement with Government by permitting the return of Hāshim Alī. A second expedition was dispatched in 1892 , which resulted in the complete pacification of the Black Mountain border.

Mahāban ('Great Forest').-A mountain in independent territory, bordering on the Hazāra and Peshāwar Districts of the North-West Frontier Province, at the eastern end of a spur of the Ilam range. It is situated on the right bank of the Indus, and rises to a height of 7,400 feet above the sea. The southern side of the hill is thickly wooded and is inhabited by Gāduns; the north side is peopled by the Amãzai Pathāns. For many years Mahāban had been identified with the site of Aornos, a strong fortress taken by Alexander. After visiting the place in 1904, Dr. Stein pointed out that it differs completely from the description given of Aornos. (See paragraph on Archaeology in BunER.)

Sāmāna Range. - A rugged range of hills in the NorthWest Frontier Province, running east and west about $33^{\circ} 34^{\prime} \mathrm{N}$. and between $70^{\circ} 5^{6^{\prime}}$ and $71^{\circ} 5^{1^{\prime}}$ E., and separating the Mirañzai valley in the Thal subdivision of Kohāt District from the Khānki valley of Tîrāh. The range has an elevation of 
5,000 to 6,500 feet; and its crest is held by a line of forts, including Fort LOCKhart, SĀragarhI, and Fort Cavagnari or GULISTĀN.

Indus (Sanskrit, Sindhu; Greek, Sinthos; Latin, Sindus).The great river of North-Western India. The Indus rises in Tibet, and then flows through Kashmir, the Frontier Province, and the Punjab, and after a final course through Sind falls into the Arabian Sea in $23^{\circ} 5^{\prime} \mathrm{N}$. and $67^{\circ} 30^{\prime} \mathrm{E}$. The drainage basin of the Indus is estimated at 372,700 square miles, and its total length at a little over r,800 miles. The towns of importance on or near its banks in British territory are, beginning from the south: Karāchi,Kotri, Hyderābād, Sehwān, Sukkur, Rohri, Mithankot, Dera Ghãzi Khān, Dera Ismail Khān, Miānwāli, Kālābāgh, Khushālgarh, and Attock.

The first section of the course of the Indus lies outside Course in British territory, and must be briefly dealt with here. The Tibet and river rises, as above stated, in Tibet $\left(32^{\circ} \mathrm{N}\right.$. and $8 \mathrm{r}^{\circ} \mathrm{E}$.) behind the great mountain wall of the Himãlayas, which forms the northern boundary of India, and is said to spring from the north side of the sacred Kailās mountain (22,000 feet), the Elysium of ancient Sanskrit literature. Issuing from the ring of lofty mountains about Lake Mānasarowar, whence also the Sutlej, the Brahmaputra, and the Kauriāla spring, it flows north-west for about 160 miles under the name of Singh-ka-bāb, until it receives the Ghar river on its south-western bank. A short distance below the junction of the Ghar, the Indus, which is supposed to have an elevation of $x 7,000$ feet at its source, enters the south-eastern corner of Kashmīr at an Kashmir. elevation of $\mathrm{r}_{3}, 800$ feet, flowing slowly over a long flat of alluvium. Following a steady north-by-west course it skirts Leh at a height of ro,500 feet and drops to 8,000 feet in Baltistān, just before it receives the waters of the Shyok river. At Leh it is joined by the Zāskār river, and is crossed by the great trade route into Central Asia via the Karakoram Pass. Early travellers like Dr. Thomson and Mr. Blane have described this portion of the Indus. The former found numerous hot springs, some of them with a temperature of $174^{\circ}$ and exhaling a sulphurous gas. Still flowing north, but more westerly, through Kashmîr territory, it passes near Skārdu in Baltistān, and reaches the Haramosh mountain $(24,300$ feet) in about $34^{\circ} 50^{\prime} \mathrm{N}$. and $74^{\circ} 30^{\prime} \mathrm{E}$. Here it takes a turn southwards at an acute angle, and passing beneath the Hattu Pir, at an elevation of 4,000 feet, enters Kohistān in the Dïr, Swāt, and Chitrāl Agency near Gur. The steepness of its fall varies, 
now becoming greater, now less. This inequality of slope has been connected with the changes that occurred in the glacial period from the damming of the river by huge glaciers and the formation of great thicknesses of lacustrine deposit. The Indus has been the cause of serious and disastrous floods; the rapid stream dashes down gorges and wild mountain valleys; and in its lower and more level course it is swept by terrific blasts. Even in summer, when it is said to dwindle down to a fordable depth during the night, it may during the course of the day swell into an impassable torrent from the melting of the snows on the adjoining heights. Opposite Skārdu in Baltistān it is, even in the depth of winter, a grand stream, often more than 500 feet wide and 9 or ro feet in depth. After leaving Gur, it flows for about 120 miles south-west through the wilds of Kohistān, until it enters the North-West Frontier Province $\left(35^{\circ} 25^{\prime} \mathrm{N}\right.$. and $73^{\circ} 5 \mathrm{r}^{\prime} \mathrm{E}$. $)$, near Darband, at the western base of the Mahāban mountain. 'The only point to which special allusion can be made in the long section of its course beyond British territory is the wonderful gorge by which the river bursts through the western ranges of the Himālayas. This gorge is near Skārdu, and is said to be 14,000 feet in sheer descent.

In the Punjab and the Frontier Province.

The Indus, on entering the Hazāra District of the NorthWest Frontier Province, 812 miles from its source, is about roo yards wide in August, navigable by rafts, but of no great depth, and studded with sandbanks and islands. It is fordable in many places during the cold season; but floods or freshets are sudden, and Ranjit Singh is said to have lost a force, variously stated at from 1,200 to 7,000 horsemen, in crossing the river. Even the large and solid ferry-boats which ply upon it are sometimes swept away. Almost opposite Attock it receives the $K \bar{A} B U L$ river, which brings down the waters of Afghannistãn. The two rivers have about an equal volume; both are very swift, and broken up with rocks. Their junction during floods is the scene of a wild confusion of waters. The Kābul river is navigable for about 40 miles above the confluence, but a rapid just above it renders the Indus impracticable. Attock, the limit of the upward navigation of the Indus, forms the first important point on the river within British territory. By this time it has flowed upwards of 860 miles, or nearly onehalf of its total length, its further course to the sea being about 940 miles. It has fallen from an elevation of 17,000 feet at its source in Tibet to about 2,000 feet, the height of Attock being 2,079 feet. In the hot season, opposite the fort, its 
velocity is 13 miles an hour; and in the cold season, 5 to 7 miles. The rise of ordinary floods is from 5 to 7 feet in twenty-four hours, and the maximum is 50 feet above coldseason level. Its width varies greatly with the season-at one time being more than $25^{\circ}$ yards, at another less than roo. The Indus is crossed at Attock by the railway bridge opened in 1883 , a bridge of boats, and a ferry. The main trunk road to Peshāwar also crosses the river by a subway on the railway bridge.

After leaving Attock, the Indus flows almost due south, forming the western boundary of the Punjab, parallel to the Sulaimān Hills. The great north road from Bannu to Sind runs for several hundred miles parallel with its western bank; and from Attock to Mahmūd Kot the Māri-Attock, Māri, and Sind-Sāgar branches of the North-Western Railway run along its eastern bank. Twelve miles below Attock the Indus receives the waters of the Haroh, a rapid stream which, rising in the Murree hiils as the Dhānd, meets the Karrāl coming down from the Mochpuri peak, and rushes through steep banks for a total course of 90 miles. At Makhad, the Sohān brings in all the drainage of Rawwalpindi and Jhelum Districts that is not taken by the Jhelum river. The Indus forms the eastern border of the two frontier Districts of Dera Ismail Khān in the North-West Frontier Province and Dera Ghāzi Khān in the Punjab with the Sind-Sāgar Doāb on its eastern bank, and only a narrow strip of British territory between it and the hill tribes of the Sulaimān ranges on the west. Just above Mithankot, in the south of Dera Ghāzi Khān District, it receives the accumulated waters of the Punjab. Between the Indus and the Jumna flow the five great streams from which the Punjab (Panj-āb, literally 'The five waters') takes its name. These are the Jhelum, the CHENĀB, the RĀvi, the BEĀs, and the SUTLEJ. After various junctions these unite to form the river PANJNAD, literally 'The five streams,' which marks for a short space the boundary between British territory and the Bahāwalpur State, and unites with the Indus near Mithankot, about 490 miles from the sea. In the cold season the breadth of the Indus above the confluence is about 600 yards, its velocity 5 miles an hour, its depth from 12 to 15 feet, and its estiniated discharge 10,000 to 25,000 cubic feet per second. During floodtimes the breadth sometimes increases to 5 miles, and the discharge to $1,000,000$ cubic feet per second. The dimensions of the Panjnad above the point of junction are somewhat less than those of the Indus during the cold season, but during the 
monsoon floods they are almost as large. The whole course of the Indus through the Punjab is broken by islands and sandbanks; but beautiful scenery is afforded along its banks, which abound with the date, acacia, pomegranate, and other trees.

In Sind. Mithankot has an elevation of only $25^{8}$ feet above the level of the sea. From Mithankot the Indus forms the boundary between the Punjab and Bahāwalpur State, until, near Kashmor, it enters Sind in $28^{\circ} 26^{\prime} \mathrm{N}$. and $69^{\circ} 47^{\prime} \mathrm{E}$. From Bukkur (in Sind) to the sea the river is known familiarly among the Sindīs as the Daryā ('the river'). Pliny writes of Indus incolis Sindus appellatus. It first touches Sind close to Kashmor town in the Upper Sind Frontier District, separating it from the Bahāwalpur State and Sukkur District. Formerly in years of high inundation its floods reached Jacobābād, finding their way thence into the Manchhar Lake. To prevent this, the Kashmor embankment, which is the largest in Sind, was erected. Leaving Kashmor the river crosses Sukkur, divides Lārkāna and Karāchi from the Khairpur State and Hyderābād District, finally emptying itself by many mouths into the Arabian Sea near Karāchi after a south-western course of $45^{\circ}$ miles through Sind. It ranges in width from 480 to $\mathrm{I}, 600$ yards, the average during the low season being 680 yards. During the floods it is in places more than a mile wide. Its depth varies from 4 to 24 feet. The water, derived from the snows of the Himālayas, is of a dirty brown colour, and slightly charged with saline ingredients, carbonate of soda, and nitrate of potash. Its velocity in the freshets averages 8 miles per hour; at ordinary times 4 miles. The discharge per second varies between a minimum of 19,000 and a maximum of 820,000 cubic feet. On an average the temperature of the water is $10^{\circ}$ lower than that of the air. Near the station of Sukkur and again at Kotri the river is spanned by a fine railway bridge. The Sukkur bridge was opened in 1889 , and resembles the Forth Bridge in having a central girder with a span of 200 feet, supported at the ends of two cantilever arms, each 310 feet long. The Indus begins to rise in March, attains its maximum depth and width in August, and subsides in September. The maximum rise registered at Kotri, near Hyderābād, was 22 feet 7 inches in 1894 . There are many other gauges on the river.

The Indus The delta of the Indus covers an area of about 3,000 square Delta. miles, and extends along the coast-line for 125 miles. It is almost a perfect level, and nearly destitute of timber, the 
tamarisk and mangrove alone supplying fuel. In these respects the delta is similar to that of the Nile, but dissimilar to that of the Ganges. The marshy portions contain good pasturage, and rice grows luxuriantly wherever cultivation is possible; but the soil generally is not fertile, being a mixture of sand and clay. In the Shāhbandar täluka are immense deposits of salt. The climate of the delta is cool and bracing in the winter months, hot in the summer, and during the floods most unhealthy.

The Indus formerly flowed down the middle of the Thal. Changes in Basira, a village in the centre of the Muzaffargarh Thal, was called Bet Basira; and at Shāhgarh, near the southern end the river of the Thal, a long lake is still extant which once formed the Indus bed. In 1800 the river at the apex of the delta divided into two main streams, known as the Baghīār and Sìtā; but in 1837 it had entirely deserted the former channel. The Khedewāri passage also, which before 1819 was the highway of water traffic to Shāhbandar, was in that year closed by an earthquake. In 1837 the Kakaiwäri, which had then increased from a shallow creek to a river with an average width at low water of 770 yards, was recognized as the highway; but before 1867 this also was completely blocked. In 1897 the river suddenly cut 3 miles inland, north of Rohri, destroying the cultivated fields and the Mando-Dahiro road. Tando Nijābat on the right bank and Mithani on the left have been swept away four times and rebuilt farther off. For the present the Hajāmro, which before 1845 was navigable only by the smallest boats, is the main estuary of the Indus. The shape of the Hajāmro is that of a funnel, with the mouth to the sea; on the east side of the entrance is a beacon 95 feet high, visible for 2 miles; and two well-manned pilot boats lie inside the bar to point out the difficulties of navigation.

The following facts illustrate further the shifting nature of the Indus. In $\mathrm{r} 845$ Ghorābāri, then the chief commercial town of the delta, was on the river bank; but in $r 848$ the river deserted its bed. The town of Keti was built on the new bank. The new bank overflowed a few years later, and a second Keti had to be built farther off. At present one of the chief obstructions to navigation is a series of rocks between Tatta and Bhimān-jo-pura, which, in 1846 , were 8 miles inland. In 1863 a thousand acres of the Dhāreja forest were swept away. The rapidity and extent of the destructive action in constant progress in the-delta may be estimated from the fact that travellers have counted by the reports as many as thirteen 
bank slips in a minute. In some places the elephant grass (Typha elephantina) does good service by driving its roots very deeply (often 9 feet) into the ground, and thereby holding it together.

Inundations and irrigation.

The entire course of the Indus in British territory, from Attock to the sea, lies within the zone of deficient rainfall, the annual average being nowhere higher than ro inches. Cultivation, therefore, is absolutely dependent upon artificial irrigation, almost to as great an extent as in the typical example of Egypt. But the Indus is a less manageable river than the Nile. Its main channel is constantly shifting ; at only three placesSukkur, Jerruck, and Kotri-are the river banks permanent; and during the season of flood the melted snows of the Himālayas come down in an impetuous torrent which no embankment can restrain. From time immemorial this annual inundation, which is to Sind what the monsoons are to other parts of India, has been utilized as far as possible by an industrious peasantry, who lead the water over their fields by countless artificial channels. Many such channels, constructed in the days of native rule, extend 30 and even 40 miles from the river bank. Recently the systematic schemes of British engineers have added numerous perennial canals, such as the Jammrao, constructed on scientific principles. The first recorded inundation of the Indus took place in 1833 ; another occurred in $184 \mathrm{I}$ on a much larger scale. This flood was said to have been caused by the bursting of a glacier which formed over an accumulation of water in the Nubra Tso, into which there was a regular and steady flow from the surrounding hills. Eventually, the glacier was burst asunder by the pressure, and the released floods poured down the Shyok valley, carrying everything before them. There was another great flood in August, $185^{8}$, when the river rose 90 feet in a few hours, and the greater part of the private property in Naushahra cantonment was destroyed. Lower down in its course considerable damage has been caused in Dera GHĀZI KHĀN District, where protective works were undertaken. Of recent years the Indus has been embanked from above Kashmor to the mouth of the Begāri canal, a distance of more than 50 miles. The embankment has proved a great protection to the North-Western Railway, which here runs at right angles to the river.

Principal canals.
A full account of irrigation in SIND will be found in the article on that Province. It must suffice in this place to give a list of the principal works, following the Indus downwards from the Punjab. The country has recently been surveyed 
with a view to a canal being led from Kālābāgh down the Sind-Sāgar Doāb, but the difficulties in the way are at present considerable. The waters of the river are first utilized on a large scale in the Indus InUndation Canals, which water a narrow strip between the Indus and the Sulaimān mountains. The canals in this tract have an aggregate length of 690 miles, of which 108 have been constructed under British rule. In Muzaffargarh District the MuZAFFaRGarh CANALS take off from the Indus and Chenāb, and in the Native State of Bahāwalpur the Chenāb and Sutlej, as well as the Indus, contribute to render cultivation possible. In Sind the following are the chief canal systems :- on the right or west bank, the Desert, Unar Wah, Begāri, Sukkur, Ghar, and Western Nāra; on the left or east, the Nāra Supply Channel, Mahi Wah, Jämrao, a branch of the Eastern Nära, and the EASTERN NĀRA with many distributaries, the principal being the Mithrao and Pinjāri. Other important canals are the Fuleli with two mouths, the Nasrat, and the Dād. The total area irrigated by canals from the Indus in $1903-4$ was :-in the Punjab, 714 square miles; in Sind, 4,925 square miles.

As a channel of navigation, the Indus has disappointed the Navigaexpectations that were at one time formed. Before British tion. arms had conquered Sind and the Punjab, it was hoped that the fabled wealth of Central Asia might be brought by this course down to the sea. But, even so far as local traffic is concerned, experience has proved in this case, as with most other Indian rivers, that the cheapness of water communication cannot compete with the superior speed and certainty of railways. Since the opening of the Indus Valley State Railway (now included in the North-Western system) in the autumn of 1878 , navigation on the Indus, whether by steamer or by native boat, has greatly fallen off. The general character of the Indus trade may be inferred from the statistics of imports and exports into the PUNJAB by 'rail and river,' which refer only to traffic borne in part or wholly on the Indus. The original 'Indus flotilla,' which was broken up in r862, placed its first steamer on the river in 1835 . In 1859 a company established another Indus flotilla in connexion with the Sind Railway, with which it was formally amalgamated in 1870 , the joint head-quarters being removed to Lahore. The railway flotilla was abolished in $1882-3$. These were not the only flotilla experiments on the Indus. In 1856 the Oriental Inland Steam Company obtained a yearly subsidy of Rs. 50,000 from Government; but, as the river current proved too powerful for 
its steamers, the company stopped the traffic, and eventually collapsed.

For the conservancy of the lower part of the river, Act I of $x 863$ (Bombay) provides for the registration of vessels, and the levy of pilotage fees by an officer called the Conservator and Registrar of the Indus, the sum realized being expended on the improvement of navigation ${ }^{2}$. A special export board, known as the Indus Commission, was constituted in rgor.

The boats of the Indus are the dundo and zaurak, both cargo-boats, the kauntal, or ferry-boats, and the dundi, or fishing-boats. The cargo-boats are sometimes of 60 tons burden, and when laden draw 4 feet of water. The state barges or jhamptis of the Sind Mìrs were built of teak, fourmasted, and sometimes required crews of thirty men.

Fish. Fish abound. At the mouths, the salt-water varieties include the Clupea neowhii, a species of herring largely consumed along the coast and in the delta. The chief of the fresh-water varieties are the palla, placed by Dr. Day under the Clupeidae, and nearly allied to, if not identical with, the hilsa of the Ganges; and the dambhro. The local consumption and also the export of dried palla are very large. Otters, turtles, porpoises, water-snakes; and crocodiles, of both the blunt-nosed and sharp-nosed species, are numerous.

[Notes on the Indus River (Karāchi, r9or).]

Swāt River (Sanskrit, Suvastu; Greek, Souastos or Souastênê).-A river of the North-West Frontier Province, formed by the junction at Kalān in Swāt Kohistãn of the Gabral and the Ushu. The former rises on the east of the Badugai pass, and the latter comes down from the higher hills of Bashkār to the north. From Kalān the Swāt river flows almost due south for about 68 miles, but at Manglaur turns abruptly to the south-west and west for 24 miles until it is joined by the Panjkora. The united waters then sweep in a great curve south-westwards to Abāzai in Peshāwar District, where they emerge to the north of the Mohmand hills into the Peshāwar valley. Here the river spreads south-east in several streams over the plain, joining the Kābul river at Nisatta after a total course of about 400 miles. Fed by glaciers and snow, it has a considerable volume in the summer months, but shrinks after the middle of September, until at midwinter it is almost everywhere fordable. In Peshāwar District the Swät River Canal takes off from the river, and a scheme for

1 The Indus Conservancy department and fees levied for its up-keep were abolished in March, 1906. 
tunnelling under the Malakand Pass and bringing its waters to the eastern part of Yüsufzai is under consideration.

Kābul River. - A river of North-Western India, which rises in Afghānistān near the Unai pass, about 40 miles west of Kābul city, in $34^{\circ} 2 \mathrm{I}^{\prime} \mathrm{N}$. and $68^{\circ} 20^{\prime} \mathrm{E}$. In its upper course it is joined by many small tributaries from the southern slopes of the Laghmān range. It is at first an inconsiderable stream, being fordable as far as $\mathrm{Ka}$ bul city. At a short distance beyond this it receives the Logar from the south, and thenceforward becomes a rapid river with a considerable volume of water. About 40 miles below Kābul city, it receives from the north the Panjshir ; 15 miles farther on, the Tagao; 20 miles below, the united streams of the Alingār and Alishang; and a few miles above Jalālābād, the Surkhāb from the south. Just below Jalālābād it is joined by the Kunar from the north. After these accessions, the Kābul becomes a large river, nowhere fordable. Flowing with great force, it hugs the north side of the Jalālābād valley until it enters the Mohmand hills, when it presses towards the north base of the Khyber range, and is confined between hills until it enters British territory near the Michni Fort. Here it divides into two branches, the Adezai on the north and the Nagūmān on the south.

The Adezai, or Hājizai, is at present the main stream. It divides the tahsīls of Peshāwar and Chārsadda for 20 miles, and after a farther course of ro miles through the latter tahsill, rejoins the Nagūmān at Nisatta, after receiving the waters of the Swät. The Nagūmān, formerly the main stream, throws off the Budhni, a small branch which supplies the Jui Shaikh canal, and after receiving the drainage of the Khyber hills, turns north and joins the Shāh Alam, itself a chord of the Nagūmān. That stream has a course of 20 miles before it reaches Nisatta, and below that place the joint stream is known as the Landai or 'short' river. The Landai flows between low banks for its first 12 miles, but below Naushahra it has cut a deep channel and its lower reaches are rocky. After a course of 36 miles, it falls into the Indus at Attock. Thus the total course of the Käbul river is about 316 miles.

From its source to Jalālābād, the river is of no value except for irrigation, which it also affords in the Frontier Province (see Kābul River Canal); from Jalālābād to Dobandi, it affords safe, and generally rapid, descent down-stream by means of rafts of inflated skins. This mode of travelling is frequently resorted to, as it saves ten marches which may be 
traversed in twelve hours when the river is in flood. The boatmen of Lālpura, Jalālābād, and Kunar are a peculiar race, keeping much to themselves, and are known under the generic title of niläbi. From Dobandi (or Nisatta) to Attock, the Kābul is navigable for boats of 40 or 50 tons.

Between Kābul city and Jalālābād, the river is fordable in places; but after it has been swelled by the waters of the Logar, the fords are not always practicable; both at Sarobi (opposite Naglu) and at Jalālābād there are alternative fords and ferries. The precarious nature of the Jalālābād ford was illustrated by a catastrophe which occurred in March, 1879 , when an officer and forty-six non-commissioned officers and men of the roth Hussars were drowned while attempting a passage in the dark. The principal ferries between Dobandi and Attock are from Nisatta to Khalīl Bandah, and from New to Old Naushahra. The railway from Naushahra to Dargai crosses the river, and there is a bridge of boats at the same site, while another has recently been constructed at Lãlpura below Jalālābād. Permanent bridges cross the river in Kābul city.

Bārā River.-A small river in the North-West Frontier Province, which rises in the highlands of Tīrāh, and flows eastward between the Safed Koh and its offshoot the Surghar range on the north and the Torghar or Ziā-ud-din range, which divides it from the Mastüra valley, on the south. In Tĩanh the Bārā valley is closely confined between these lofty, rugged, and pine-clad ranges ; but it is thickly dotted with fortified homesteads, and the passage by the British force in 1897 was most arduous. Entering Peshāwar District near Fort Bārā, a few miles south-west of Peshāwar city, the Bārā takes a northeasterly course and falls into the Kābul river after a total length of 100 miles. The water-supply of Peshãwar is drawn from this river by a closed masonry flume taking off 2 miles above the fort. The river has cut its way through the soft soil of the Peshāwar valley to a considerable depth and now runs far below the level of the surrounding country, but from time immemorial it has been used for irrigation on both banks. The supply of water is, however, small, not exceeding 158 cubic feet per second as a rule, though after rain in the Tirāh hills it is greatly increased, and the stream then brings down a reddish silt which is extremely fertilizing. In 1898 a weir was constructed near the Afridi village of Ilm Gudr at a cost of Rs. 20,000. The Bārā canal, taking off here on the north bank, has two branches named after the tribes whose lands they command: the Khalil or Sangu, which cost Rs. 23,500; 
and the Mohmand or Shaikhann, which cost Rs. 20,600. These branches were so designed as not to interfere with the ancient watercourses, over which they were carried by means of aqueducts. Both branches run through tunnels in conglomerate rock immediately above the weir, the Sangu tunnel being I,600 feet in length and the Shaikhān 7 ro feet. The headworks are protected by a blockhouse. The canal is managed by the Deputy-Commissioner under the Peshawwar Canal Regulation of 1898 . Irrigated 57 square miles in 1903-4.

Kurram River.-A river in the North-West Frontier Province, which rises at the base of the Rokian defile in Afghānistān and, after traversing the Khost district of that State, enters the country of the Turis or the Kurram Valley proper near Kharlāchi, 40 miles from its source. It then flows south-east for about 55 miles, through the whole length of the Political Agency of Kurram, till it reaches Thal in Kohāt District. Here it turns southward through the country of the Käbul Khel Wazirs, and after receiving the Kaitu river, which drains the Afghãn district of Khost, it enters Bannu. Traversing that District with a south-easterly course it cuts its way through a narrow gorge, known as Darra Tang, in the hills that encircle Bannu District, into the Isa Khel plain, and falls into the Indus opposite Miānwāli. In its course through the Kurram Valley it is mainly fed by streams from the Safed Koh, the chief of which are the Kirmān and Kurmāna.

Tochi River (or Gambila).-A river in the North-West Frontier Province, which rises in Afghānistān and flows through the Northern Waziristān Agency and Bannu District. Its course through Northern Wazīristãn is due east, through the valley of Upper and Lower Daur. Thence it debouches on the Bannu plain and, running south-east for most of its course, curves eastward again and falls into the Kurram, east of Lakki. It irrigates considerable areas in both Daur and Bannu District ; but owing to the increase in cultivation in Daur since the British occupation of the valley in 1895 , there has been a great decline in the Bannu irrigation. The total length of the river is between roo and 150 miles.

Guma1.-A river on the north-west frontier of India, which rises near Sarwandi on the Koh Nāk range in Afghānistān, and flowing south-east enters British territory at Domandi, where it is joined by the Kundar. It runs thence eastward till it reaches Murtaza in Dera Ismail Khān District. Between Domandi and Murtaza the Gumal receives the waters of the Wana Toi (north bank) at Toi Khula, and the Zhob (south 
bank) at Khajuri Kach. From Domandi to Khajuri it is the boundary between the North-West Frontier Province and Baluchistan (Zhob Agency). The channel of the Gumal passes to the Indus a few miles south of Dera Ismail Khān cantonment; but, except in times of flood, all the water is used for irrigation in Dera Ismail Khān District and does not reach the Indus.

Swāt River Canal.-A perennial irrigation work in the Peshāwar District of the North-West Frontier Province, taking off from the right bank of the Swāt river at Abāzai, and irrigating about 155,000 acres. The place of a weir is taken by a natural reef stretching across the river below the head regulator. The regulator has seven openings of 6 feet each, and is protected at each end by fortified blockhouses, forming one of the chain of frontier posts garrisoned by the border military police. The main channel has a width of 31 feet and a depth when full of 7.35 feet; it can carry a supply of 865 cubic feet per second. In a total length of $22 \frac{1}{2}$ miles there are no less than 21 drainage works, which carry under or over the canal the water of the numerous mountain torrents that intersect its course. These are for the most part crossed by massive stone aqueducts, and the canal banks for some distance above and below these crossings are of a great height. About 186 miles of distributary channels have been aligned on the watersheds between the torrents, the most important being the trans-Kalpāni distributary, which has a discharge of 94 cubic feet per second and a length of nearly $14 \frac{1}{2}$ miles, and in which there are fourteen drainage works of importance.

The tract commanded by the canal is that portion of the dry, sparsely populated Yüsufzai plain which is bounded on the north by the canal itself, on the west and south by the Swāt and Kãbul rivers, and on the east by the Mokam nullah, a tributary of the Kalpani. The country rises so rapidly on the north of the canal up to the foot of the hills that it cannot be brought under command. The canal tract itself is cut up by innumerable nullahs running generally from north to south, and carrying the drainage from the hills on the north to the Swāt and Kābul rivers on the west and south. The great cost of the canal was due to the difficulty of taking it across these channels, some of which are of great size.

The main canal was opened in 1885 , and the trans-Kalpāni distributary in 1899. The Naushahra minor, a channel irrigating two grass farms near Naushahra, was constructed in 1901. The area irrigated in both harvests during the three 
years ending $1901-2$ averaged 161,000 acres, and in $1903^{-4}$ it was 159,000 acres. The total capital expenditure to the end of March, 1904 , was $4 \mathrm{r} \cdot 4$ lakhs. The canal was originally sanctioned as a protective work, no profit being anticipated owing to the high cost of construction. The whole accumulated interest charges were, however, paid off in fifteen years, and the net revenue in $1903-4$ (Rs. 4,57,000) exceeded Io per cent. on the capital expended. The canal has thus become a remunerative investment to Government, besides contributing in no small degree to the peace of the border. It fails, however, to touch the part of Yu unsufzai between the main channel and the border hills to the north where water is badly needed, and it is accordingly proposed to drive a tunnel through the Malakand range and tap the Swāt river near Chakdarra. As the river is fed from the snows, it attains its greatest volume in the summer months, and thus water would be abundant just at the time it is most needed. A canal would be made from Dargai, with branches running west to Abāzai, the head of the parent canal, and south-east to the Indus at Pehūr and the Kābul river at Jahāngĩra. These branches would practically command all of Peshãwar District north of the Swät and Kābul rivers which is not already canalirrigated-an area of about 600 square miles.

Kābul River Canal.-A perennial irrigation work in the Peshāwar District of the North-West Frontier Province. It is a revival of an old Mughal canal, and takes off from the right bank of the Kābul river at the village of Warsak on the border of British territory, about 3 miles up-stream from Michni fort. The main line is 20 feet in width at the off-take, and can carry more than 300 cubic feet a second. It crosses the watershed of the country, passing over thirty-six drainage channels of greater or less size, and running close to Peshāwar terminates at the fortieth mile near Naushahra. The distributaries include four branches, with a total length of 19 miles, the largest being the Kuror branch, $9 \frac{1}{2}$ miles long. A small private canal is situated near the canal head. The tract commanded is a long narrow strip of irregular width, bounded on the south and west by the canal itself, and on the north and east, for the upper two-thirds of its length, by the low-lying ground irrigated by old proprietary canals, of which the Jui Shaikh is the most important; while for the lower third of its length the Kābul river is the boundary.

The area now commanded exceeds 30,000 acres. It is at present considerably interspersed with that irrigated by the Jui 
Shaikh and other private canals, as well as by the Bārā river works ; but there seems every prospect of the greater portion of all this area ultimately coming under the canal. Irrigation is chiefly for the autumn harvest, and the area of crops actually irrigated during the three years ending 1902 averaged 30,173 acres; in $1903-4$ it was 27,800 acres. The canal was opened in 1893 , the Kuror branch being added subsequently. The capital cost up to March, 1904, was Rs. 6,45,000, and the net income in 1903-4 was Rs. 90,800, giving a return of nearly 24 per cent. On October $\mathrm{I}, 1903$, the revenue management of this canal was taken over by the Irrigation department. An extension called the Hazār Khāni branch is now under construction.

Amb.-Village in independent Tanāwal, North-West Frontier Province, situated in $34^{\circ} 18^{\prime} \mathrm{N}$. and $72^{\circ} 55^{\prime}$ E., on the western bank of the Indus. The ruler of the territory takes his title as Nawāb of Amb from this place, where he resides in winter.

Derajāt.-The local name of the level plain between the Indus and the Sulaimān range, lying between $29^{\circ} 30^{\prime}$ and $34^{\circ}$ $15^{\prime} \mathrm{N}$. and $69^{\circ} 15^{\prime}$ and $72^{\prime}$ E., in the Punjab and North-West Frontier Province. The tract includes, and derives its name from, the three Deras : DeRA Ismail KHĀN, Dera Fateh Khān, and Dera Ghāzi KhĀN. It extends north to the Sheikh Budin range, which divides it from the Marwat plain, and south to the town of Jāmpur, having thus a length of 325 miles. Its breadth averages 50 miles. The Derajāt owes its existence as a historical area to the Baloch immigration in the fifteenth century. Sultān Husain, the Langāh sovereign of Multān, being unable to hold his trans-Indus possessions, called in Baloch mercenaries, and assigned these territories to Malik Sohrāb Dodai in jaggir. Sohrāb's sons, Ismail and Fateh Khān, founded the two deras or settlements named after them ; while Hāji Khān, the head of the old Mirāni tribe of the Balochs, who had also entered the service of the Langāhs, assumed independence in the reign of Mahmūd, Sultān Husain's grandson, and founded Dera Ghāzi Khān, naming it after his son and successor. When Hāji Khān died in I 494, the tract was a deserted waste but contained a few isolated towns. The Mirānis soon came into conflict with the Nāhars, who ruled the country on the Indus to the south, the boundary between the rival powers lying north of Rājanpur; but the Mirānis also held some territory east of the Indus in the modern District of Muzaffargarh. On Bābar's conquest of 
Northern India in $\mathbf{r}_{5} \mathbf{2 6}$ the Mirānis submitted to him, and at his death the Derajāt became a dependency of his son Kāmrān, the ruler of Kābul. Under Humāyūn the Baloch immigration increased, and they gradually pushed the Nāhars farther south. All the Baloch tribes acknowledged the overlordship of the Mirāni Nawābs, who ruled for about fifteen generations at Dera Ghāzi Khān, taking alternately the style of 'Hāji' and 'Ghāzi Khān.' At Dera Ismail Khān ruled the Hot Baloch chiefs, who bore the title of Ismail Khān from father to son and also held Daryā Khān and Bhakkar, east of the Indus. Early in the eighteenth century the Mirānis lost their supremacy, being overwhelmed by the Kalhoras of Sind; and when in $1739 \mathrm{Nādir}$ Shāh acquired all the territory west of the Indus, he made the Mirāni Wazīr, Mahmūd Khān Gūjar, governor in Dera Ghāzi Khān under the Kalhora chief, who also became his vassal. Under Ahmad Shāh Durrāni the Kalhoras and the Mirānis, now in a state of decadence, contended for possession of Dera Ghāzi, Khān, but Mahmūd Khān Güjar appears to have been its real governor. He was succeeded by his nephew, who was killed in $r 779$, and the Durrānis then appointed governors direct for a period of thirtytwo years. Meanwhile the last of the Hot chiefs of Dera Ismail Khān had been deposed in 1770 , and his territories also were administered from Kābul. In 1794 Humãyūn Shāh attempted to deprive Zamān Shāh Durrāni of his kingdom, but he was defeated and fell into the hands of Muhammad Khān Saddozai, governor of the Sind-Sāgar Doāb. As a reward for this capture, Zamān Shāh bestowed the province of Dera Ismail Khān on Nawāb Muhammad Khān, who governed it from Mankerā by deputy. His son-in-law, Hāfiz Ahmad Khān, surrendered at Mankerā to Ranjit Singh in $182 \mathrm{r}$, and at the same time tribute was imposed by the Sikhs on the chiefs of Tānk (Sarwar Khān) and Sāgar. Dera Fateh Khān was also occupied; but Dera Ismail Khān, to which Hafiz Ahmad Khān was permitted to retire on the fall of Mankerā, remained independent till $\mathrm{r}_{8} 3^{6}$, when Nao Nihāl Singh deposed Muhammad Khān, the son of Hāfiz Ahmad Khān, and appointed Dīwān Lakhi Mal to be Kardār. Dīwān Lakhi Mal held this post till his death in 1843 , and was succeeded by his son Diwann Daulat Rai, who enjoyed the support of the Multāni Pathān Sardārs. He was bitterly opposed by Malik Fateh Khān Tiwāna, who had also procured a nomination as Kardār from the Sikh Durbar. These rivals contended for supremacy with varying success until 1847 , when the Diwān 
then in possession was deposed on the recommendation of Sir H. Edwardes, who appointed General Van Cortlandt to be Kardār. The Derajāt passed to the British in 1849 , and is now divided between the Districts of Dera Ghāzi Khān in the Punjab and Dera Ismail Khān in the North-West Frontier Province.

Gandhāra (the Gandaria of the Greeks).-The ancient name for the tract on the north-west frontier of India which comprised the whole lower valley of the Käbul river, the ancient Kophene or Kubhā, from the $\mathrm{Kau}$ or Alingār river near $70^{\circ} \mathrm{E}$. to the Indus, and from the Safed Koh and Kohat range on the south to the borders of the Swant valley on the north. It thus included the modern District of Peshāwar, with part of Kohāt, the Mohmand country, Swāt, Bãjaur, and Buner, and at one period even embraced within its limits the great city of Takshasilā, east of the Indus. Its length was 170 miles from west to east at its greatest, and 100 miles from north to south. Its people were known to Herodotus, Hekataios, Ptolemy, and Strabo as Gandarioi or Gandarae, and furnished a contingent to Darius in his invasion of Greece. Gandhāra was included in the Arachosian satrapy of the Achaemenid kingss of Persia. At different times Pushkalāvati (the Peukelaotis of the Greeks), Purushapura (Peshāwar), and Udabhāndapura (UND) formed its capital. The province between the Swãt and Indus rivers, corresponding to the modern Yūsufzai country, was known as Udyāna or Ujjāna, and to the Greeks as Suastene. At times it formed a separate principality. Gandhāra was a great seat of the Buddhist religion and Graeco-Bactrian culture in the centuries after Alexander's invasion, until about A.D. $5 \mathbf{r}_{5}$ Mihirakula, the Hun, overran Udyāna and Kashmīr and oppressed the Buddhists. Of the Chinese pilgrims who visited Gandhāra, Fa Hian found (c. 404) 500 monasteries and the people devoted to the Buddhist faith; in the seventh century Hiuen Tsiang laments its decline; while fully roo years later (757-64) U-K'ong still found 300 monasteries and princes who were zealous patrons of the monks. Gandhāra has given its name to the Graeco-Buddhist sculpture found so abundantly in this region.

Pakhli.-An ancient sarkār or district of the Mughal sübah of the Punjab, now included in the Hazāra District of the North-West Frontier Province. Pakhli roughly cor-

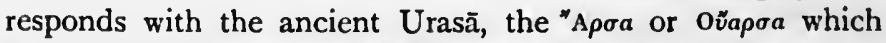
Ptolemy places between the Bidaspes (Jhelum) and the Indus. 
Its king was named Arsakes in the time of Alexander. Hiuen Tsiang found it tributary to Kashmir. In the Kashmir chronicle, called the Rājatarangini, it appears, now as a separate kingdom, now as tributary to that State. In it lay Agror, the ancient Atyugrapura. In Bābar's time this tract was held by the Khakha and Bambha tribes, whose chiefs had been the ancient rulers of the country east of the Indus, but had been driven out by the Gïbari Sultāns of Bājaur and Swāt ; and the tract derives its name from Pakhli, one of these conquerors. In the Ain-i-Akbari it is described as bounded on the east by Kashmir, on the south by the country of the Gakhars, on the west by Attock, and on the north by Kator (Chitrāl). Under Durrāni rule Saādat Khān was chosen as chief of Pakhli, then a dependency of Kashmir. He founded the fort of Garhi Saādat Khān, which was the head-quarters of Azād Khān's rebellion against Tìmūr Shāh. Early in the nineteenth century Pakhli comprised three districts: Mansehra in the south and south-east, Shinkiari (subdivided into Kandhi and Maidān) in the north-east, and Bhir-Kand in the centre. The valleys of Kāgān, Bhogarmang, and Agror were dependent on it.

Und (Hind, Ohind, Waihind).--Village in the North-West Frontier Province, situated in $34^{\circ} 2^{\prime} \mathrm{N}$. and $72^{\circ} 27^{\prime}$ E., I 5 miles above Attock, on the west bank of the Indus, just beyond the north-east corner of Peshāwar District. It marks the site of the ancient Indian Udakā or Uda-bhanndapura, the U-tokia-han-ch'a of the Chinese pilgrim Hiuen Tsiang, once the capital of the Turki and Hindu Shāhi dynasties, which ruled the Kābul valley and Gandhāra immediately before the Muhammadan invasion. Hiuen Tsiang in the seventh century A. D. describes it as a rich city, 4 miles in circumference. The hard-won victory by which Mahmūd of Ghazni opened his way into the Punjab was fought before Waihind, the name by which the place was known to Alberūni and the Muhammadan historians. It remained a place of some importance after this event, for Govinda-khāna, ruler of the Indus region and Gandhāra, was expelled from it by Shahāb-ud-dīn, king of Kashmir, in the fourteenth century. 


\section{DISTRICTS, ETC.}

Boun- Hazāra District.-Northernmost District of the Northdaries, con- West Frontier Province, and the only territory of that and hill Province east of the Indus. It lies between $33^{\circ} 44^{\prime}$ and and river $35^{\circ} 10^{\prime} \mathrm{N}$. and $72^{\circ} 33^{\prime}$ and $74^{\circ} 6^{\prime} \mathrm{E}$., with an area of $2,85^{8}$, systems. or, including Tanãwal, 3,062 square miles. The District consists of a long tongue of British territory running north and south for 120 miles. The southern base is 56 miles in width, and the centre 40 , while the Kāgān valley, in the north-east, is only about 15 miles broad. On the north the Kāgān range separates the District from Chilās, a dependency of Kashmīr; and on the east the range which borders the left bank of the Kunhār river and the river Jhelum separates it from Kashmīr, Punch, and the Punjab District of Rāwalpindi ; north-west lie the Black Mountain and the lofty ranges which overhang the eastern bank of the Indus; and on the south is the Attock District of the Punjab. Thus the District lies like a wedge of British territory driven in between Kashmir on the east and the independent hills on the west.

Hazāra presents every gradation of scenery, altitude, and climate. The valley of the Harroh, only 1,500 feet above the sea-level, merges into the Hazāra plain, an area of 200 square miles, with a mean elevation of 2,500 feet. Higher again is the Orāsh plain, where Abbottābād lies between 4,000 and 5,000 feet above the sea. Lastly the Kăgān valley, comprising one-third of the total area, is a sparsely populated mountain glen, shut in by parallel ranges of hills which rise to I 7,000 feet above the sea. Never more than 15 miles apart, these ranges throw out spurs across the valley, leaving only a narrow central gorge through which the Kunhār river forces an outlet to the Jhelum.

The scenery is picturesque and ever-changing. Distant snowy ranges to the north; the higher mountains of Hazāra, clothed with pines, oaks, and other forest trees, the lower ranges covered with grass and brushwood ; cultivation appearing on every available spot, from the small terraces cut with great labour in the hill-sides to the rich irrigation of the 
Haripur and Pakhli plains; water in every form, from the swift torrents of the Kunhār and Jhelum and the strong deep stream of the Indus, to the silent lakes of the Kāgān valley - all these suggest Kashmir and offer a vivid contrast to the arid plains of Northern India.

Hazāra may be described geologically as a section of the Geology. earth's crust coming well within the area of Himālayan disturbance, although the trend of the hill-ranges is altered from north-west-south-east to north-east-south-west. It is divisible into four distinct zones or belts of formations separated from one another by faults with overthrust, and each zone exhibits more plication or metamorphism as the higher and more north-westerly regions are approached. The first, to the north-west, is composed of metamorphic schists and sills of gneissose granite, and includes most of the country northwest of Abbottābād and the Dor valley. The second zone is composed of a great and ancient slate series, with outliers of younger rocks in the high, isolated hill-groups north-east of Abbottābād. The next in order, together with the outliers of that just described, comprise a great series of marine deposits beginning with a marked unconformity and basal conglomerate, and extending from the infra-Trias (Devonian?) up to Nummulitic, the rocks being mostly limestones or dolomitic limestones with subordinate shales and sandstones. In this series the Trias and Nummulitic are well developed, while the Jura cretaceous strata are comparatively thin. Last of all are the Upper Tertiary zone of Murree sandstone and the lower and upper Siwallik sandstones and conglomerates to the south, stretching away into the Rāwalpindi plateau.

A coaly layer is found below the Nummulitic limestone in the Dor and neighbourhood. It is much crushed, uncertain in thickness, and mixed with much clay. Its value (if any) requires proving ${ }^{1}$.

The trees of the District are described below under forests. Botany. Generally speaking the flora is extremely varied, in the south embracing most varieties commonly found in the plains of Northern India, and in the hills including every type of Alpine vegetation until the extreme limit of growth is reached.

Leopards and black bears are found in all the hill tracts; Fauna. hyenas are common in the lower hills, and wolves are occasionally seen. Foxes, hill martens, porcupines, hedgehogs, mongooses, and burrowing rats are common throughout the

1 C. S. Middlemiss. Memoirs, Geological Survey of India, vol. xxvi. 
District. Ibex and musk deer are found in Kāgān. Game birds are not numerous. Various kinds of pheasant are found at elevations from 5,000 to 12,000 feet, and partridges and the commoner water-fowl abound lower down. Mahseer are plentiful in the Indus and Jhelum and in the lower reaches of the Harroh and Siran.

Climate and temperature.

Rainfall.

History.

The climate is as varied as the scenery. The hot season in the south vies with that in the adjoining Districts of Rawwalpindi and Attock. In the central plateaux the heat of summer is materially less, and the winter proportionately severe. The line of perpetual snow is between 14,000 and 15,000 feet above sea-level. The climate is, however, healthy, and well suited to Europeans. Malarial fevers in the spring and autumn, and various affections of the lungs in winter, are the chief diseases. The rainfall is abundant, varying from 30 inches in the south to 50 inches or more in Abbottābād and the neighbouring hill stations. The heaviest fall in the last twenty years was 79 inches at Abbottābād in $1893-4$, and the lightest 15 inches at Haripur in $189 \mathrm{I}-2$.

The origin of the name Hazāra is obscure. It has been identified with Abisāra, the country of Abisares, the chief of the Indian mountaineers at the time of Alexander's invasion. Dr. Stein regards it as derived from Urasā, the ancient name of PAKHLI ; but a possible derivation is from Hazāra-i-Karlugh, or the Karlugh legion, which was settled in this tract by Tìmūr after his invasion of India. Little is known of the history of the tract before the Durrānis. The name indeed occurs in the Ain-i-Akbari, and is mentioned by Firishta. From these writings we gather that the Hazāra plain formed part of the Attock governorship, while other parts of the modern District were held by the same Gakhars who played so prominent a part in the history of Rāwalpindi. When the Mughal dynasty declined and the Afghãn peoples from across the Indus grew more aggressive, they found Hazāra an easy prey; Gakhar rule had grown weak, and the old families of the Gūjars, Kharrals, and Dhūnds were losing their vitality.

In 1752, Hazāra passed definitely under the sway of Ahmad Shāh Durrāni. The District formed the most convenient route to Kashmir and also a useful recruiting area. Hence the Durrānis were at pains to repress disorder, but troubled themselves little about the internal administration or even the revenue payments of the tract. By the beginning of the nineteenth century the Durrānis had grown weak and Hazāra proportionately unruly. Sikh rule, however, was not established 
without preliminary defeats. In 1818 Ranjit Singh formally annexed Hazāra; but in 1820 his generals were defeated, and again in 1821 Amar Singh was defeated and slain on the Harroh. Sardār Harī Singh, the governor of Kashmīr, was now sent to Hazāra ; but it took him three more years to subdue the warlike mountaineers of the outer hills, and it was not till $183^{6}$ that the Gakhars of Khānpur were finally subdued. The governorship of Hazāra was at this time no sinecure. In 1845 , the disorganization of the Sikh rule at Lahore tempted the people to rise once more, and so successful were they that Dīwān Mūlrāj, governor of Hazāra, retired to Hassan Abdāl in 1846 . The people assembled at Harippur and tried to restore former conditions. Meanwhile, the first Sikh War had come to an end, and Hazāra was made over to Rājā Gulāb Singh, together with Kashmir. In 1847 the Rājā gave back Hazāra to the Lahore Darbār in exchange for land near Jammu, and Major James Abbott was sent to settle the country. By fair assessments, by liberality to the chiefs, and by a display of vigour and firmness when occasion required it, he completely pacified Hazāra in less than a year. During the second Sikh War Major Abbott maintained his position single-handed in the hills, cut off by the Sikh army from all assistance. During the Mutiny the District was under another strong man, Major Becher, and no disturbances of importance took place. Since 1857, the Black Mountain has been the only focus of disturbance, but the expeditions of $1868,1888,1891$, and 1892 seem to have effectually quieted the country.

The archaeological remains so far discovered in Hazāra are Archaeonot numerous, but one is of great interest and importance. logy. This is an inscription on three boulders near the base of the Bareri Hill close to Mānsehra, containing the first thirteen of the fourteen rock edicts of Asoka (third century в.с.). There are one or two traces of stippas in other parts of the District. Coins of the Graeco-Bactrians, of Azes (first century B.C.), of Augustus, of the nameless king who called himself 'Soter Megas,' of the early Kushan kings, and of the Hindu Shāhis have been discovered in Pakhli. Traces of ancient forts or villages, remains probably of the Hindu dynasties which governed Hazāra under its former name Urasā (the modern Rāsh or Orāsh) before the Muhammadan occupation, are found here and there.

Hazāra District contains 4 towns and 914 villages. Its The population at each of the last four enumerations was : (1868) people. 367,2 I 8 , (r 88 r) 407,075 , (r8gr) 5 r6,288, and (r 901 ) 560,288 . 
The principal statistics of population in rgor are shown below :-

\begin{tabular}{|c|c|c|c|c|c|c|c|}
\hline \multirow[b]{2}{*}{ Tahsïl. } & \multirow{2}{*}{ 总 } & \multicolumn{2}{|c|}{ Number of } & \multirow{2}{*}{ 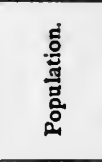 } & \multirow{2}{*}{ 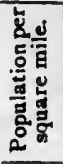 } & \multirow{2}{*}{ 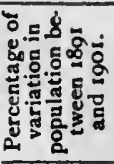 } & \multirow{2}{*}{  } \\
\hline & & 宸 & 总 & & & & \\
\hline $\begin{array}{l}\text { Abbottābād } \\
\text { Harīpur. } \\
\text { Mānsehra }\end{array}$ & $\begin{array}{r}715 \\
657 \\
1,486\end{array}$ & $\begin{array}{l}2 \\
1 \\
1\end{array}$ & $\begin{array}{l}359 \\
311 \\
244\end{array}$ & & $\begin{array}{l}273 \\
228 \\
124\end{array}$ & $\begin{array}{l}+10.7 \\
+\quad 6.1 \\
+\quad 10.3\end{array}$ & $\begin{array}{l}3,535 \\
4,715 \\
2,104\end{array}$ \\
\hline Total & 2,858 & 4 & 914 & $5^{28,666}$ & 185 & ... & 10,354 \\
\hline Tanāwal & 204 & $\cdots$ & $\ldots$ & 31,622 & 155 & ... & $5^{16}$ \\
\hline Grand total & 3,062 & $\ldots$ & ... & 560,288 & 184 & +8.5 & 10,870 \\
\hline
\end{tabular}

Population has increased by 8.5 per cent. during the last decade, the increase being greatest in the Abbottābād tahsil and least in that of Haripur. It is divided into three tahsils: Abbottābād, Harīpur, and Mānsehra. The head-quarters of these tahsils are at the places from which each is named. The towns are the municipalities of АвBоттĀBĀD (the head-quarters of the District), Harīpur, Nawäshahr, and Baffa. The District also contains the hill stations of Nathia Gall with DUNG $\bar{A}$ GaLI (the former being the summer head-quarters of the Local Government), Chängla Gali, and Thandī̄nI ; and the hill cantonments of Bāra Gali, Kālā Bagh, Khaira Gali, and Ghora Dakka. Muhammadans number 533,000 , or more than 95 per cent. of the total; Hindus 23,000; and Sikhs 4,000. The language spoken is chiefly a dialect of Western Punjābi, known locally as Hindki. Pashtū is spoken on the Black Mountain border, and the Güjars have a dialect of their own called Gūjarī.

Castes and In Hazāra, Pathāns are not the predominant race. They occupa- number only 55,000 , while the Gūjars, who profess to be
tions. aborigines, number 92,000, and the Awāns 9r,000. Tanaolis (59,000), though not Pathāns, are closely allied to them by custom and tradition. Dhūnds, another aboriginal tribe, number 25,000, Swātis 33,000, and Kharrals 16,000. The Saiyids, $(23,000)$ exercise great influence over the other Muhammadans. Of the trading classes, Khattris number 13,000 and Aroras only 4,000. Brāhmans number 5,000. Of the artisan classes, the Julāhās (weavers, I6,000), Tarkhāns (carpenters, I I, 000 ), Mochīs (shoemakers and leather-workers, 9,000), and Lohārs (blacksmiths, 9,000) are the most important. The Kashmiris, who live mainly by woollen industries, number 15,000 . The 
chief menial classes are the Nais (barbers, 7,000) and Musallis (sweepers, 3,000). About 2,000 persons returned themselves as Turks, descendants of the Turkomanns who came with Tīmūr in $\mathbf{1} 391$. Agriculture supports 72 per cent. of the population.

The Church Missionary Society opened a branch at Abbott- Christian ābād in 1899 , and the Peshāwar branch of the society has an missions. outpost at Haripur. In I 901 , the District contained I 7 native Christians.

The level portion of the District enjoys a seasonable and General constant rainfall of about 30 inches; the soil is superior to agriculthat of the hill tracts and more easily cultivated, and the spring ditions. harvest is accordingly superior. The best-irrigated and manured lands are equal to the most fertile in the Punjab, and the harvests are more certain than in the adjacent District of Rãwalpindi. The low dry hills have a climate and rainfall similar to that of the plains, but the soil is much poorer. In the temperate hills and high land in the middle of the District the rainfall àverages 47 inches, and snow falls occasionally; the autumn crop is here the more valuable, but a fair proportion of spring crops are raised. The mountain tracts have an excessive rainfall and a severe winter; so that there is but little spring harvest. The soil in the open portion of the District is deep and rich, the detritus of the surrounding hills being lodged in the basin-like depressions below; the highlands have a shallow and stony covering, compensated for by the abundant manure obtained from the flocks of sheep and cattle among the mountain pastures. The spring harvest, which in 1903-4 formed $4 \mathrm{r}$ per cent. of the total crops harvested, is sown in the higher hills in October, and lower down in November and December; the autumn crops are sown in the hills in June and July, while in the lower lands seed-time varies from April to August with the nature of the crop.

The District is held chiefly on the pattidäri and bhaiy $\bar{a}$ - Chief agrichārā tenures, zamīndāri lands covering about 339 square miles. cultural The following table shows the main statistics of cultivation in 1903-4, areas being in square miles :statistics and principal crops.

\begin{tabular}{|c|c|c|c|c|}
\hline Tahsīl. & Total. & Cultivated. & Irrigated. & Forests. \\
\hline $\begin{array}{l}\text { Abbottābād } \\
\text { Harīpur : } \\
\text { Mānsehra }\end{array}$ & $\begin{array}{r}715 \\
657 \\
1,486\end{array}$ & $\begin{array}{l}207 \\
231 \\
199\end{array}$ & $\begin{array}{l}\ldots \\
33 \\
19\end{array}$ & $\begin{array}{r}75 \\
39 \\
121\end{array}$ \\
\hline Total & $2,8,8$ & 637 & $5^{2}$ & 235 \\
\hline
\end{tabular}

Maize covers the largest area, being grown on 273 square 
miles in $1903-4$. Wheat $(171)$ comes next in importance, followed by barley (78).

Improve- The cultivated area has increased by ro per cent. since the ments in agricultural practice. settlement in 1874 . The chief field for extension lies on the hill-sides, large areas of which can be brought under cultivation by terracing; but until the pressure of the population on the soil becomes much heavier than it is at present, there is little prospect of any considerable progress in this direction. Nothing has been done to improve the quality of the crops grown. The potato was introduced shortly after annexation, and is now largely cultivated. A sum of Rs. 14,700 is outstanding up to date on account of loans to agriculturists, and Rs. 4,856 was advanced during $1903-4$ for this purpose.

Cattle, Cattle are most numerous in the hilly portions of the Disponies, and trict. The breed is small, and the cows are poor milkers, but sheep. the introduction of bulls from Hissār has done a good deal to improve the quality of the stock. Sheep and goats are grazed in the District in large numbers, chiefly by Güjars ; the larger flocks migrate at different seasons of the year between Kāgān and Lower Hazāra or Rāwalpindi. The sheep are of the ordinary thin-tailed breed, and attempts to cross them with English stock and to introduce merino sheep are being made. Sheep and goats are largely exported to the cantonments and towns in Peshāwar, Rāwalpindi, and Jhelum. The local breed of horses is small ; the Civil Veterinary department maintains seven horse and twenty-one donkey stallions, and one horse and two pony stallions are kept by the District board. The Abbottābād and Mānsehra tahsīls possess a large number of mules. A few camels are kept in Lower Hazāra.

Irrigation. The area irrigated in $1903-4$ was 52 square miles, or 8 per cent. of the cultivated area. Of this, only $\mathrm{r} \cdot 4$ square miles were supplied by wells, 377 in number, which are confined to the Indus bank and the plain round Haripur. They are built for the most part of boulder masonry, and are worked by bul'locks with Persian wheels. The chief method of supply is by cuts from the Harroh, Dor, and Siran rivers and minor hill streams. The undulating formation of the valleys, and ravines which intersect them, make any considerable extension of irrigation very difficult.

Forests. The two main classes of forests in Hazāra District are: the 'reserved' forests, in which only few rights of user are admitted, although the villagers are entitled to a share in the price of the trees felled for sale; and the village forests, in which Government retains a similar share, but which are other- 
wise practically left to the charge of the villagers, subject to the control of the Deputy-Commissioner.

The 'reserved' forests, which are situated mainly in the north and east, cover 235 square miles, and yield annually about 80,000 and 40,000 cubic feet of deodār and other timber, respectively. The Jhelum and its tributaries convey the timber not used locally. The most important forests, which lie between altitudes of 5,000 and 10,000 feet, contain deodär, blue pine, silver fir, spruce, and Quercus incana, dilatata, and semecarpifolia. In the Gali range, where deodār is now scarce, trees of hardwood species are abundant, whereas in the drier Kāgān range and in the Upper Siran valley pure deodār forests are not uncommon, but the variety of species is smaller. Between 10,000 feet and the limit of tree growth at about r 2,500 feet, the spruce and silver fir are the most common. In the south some hardwood forests of poor quality are of importance for the supply of firewood, and at elevations between 3,000 and 6,000 feet there is a considerable extent of forest in which Pinus longifolia predominates. Forest fires, which formerly did much damage, are now becoming less frequent. Working-plans have been prepared and will shortly come into force for all the 'reserved' forests which are controlled by the Forest officer in charge of the division. In 1903-4 the forests yielded a revenue of Rs. 83,000 .

The village forests are not so strictly preserved. Those of the Harīpur tahsīl and parts of Abbottābād, including Tanāwal, produce only fuel; but in the northern parts of the latter tahsìl and in Mānsehra the forests contain coniferous and deciduous trees, which increase in value as the forests become less accessible. These village forests are controlled, under the Hazāra Forest Regulation of 1893 , by the Deputy-Commissioner through the village headmen, on the principle that the villagers, while taking without restriction all that they require for their own needs, shall not be permitted to sell timber or firewood cut from them.

Of the 1,700 square miles of waste land in the District, only 200 are clad with timber-producing trees, 200 more forming fuel reserves. About 200 square miles have been demarcated as village forests, to check denudation and to prevent waste, while securing the produce to the villagers for the satisfaction of their needs.

As already mentioned, coal exists in the District, but has Mines and not been worked. Limestone, building stone, and gypsum are min?rals. abundant, and coarse slate is found in places. Antimony and 
Arts and manufactures.

oxide of lead have been observed, and iron occurs in considerable quantities, but is little worked.

The industries of Hazāra are of only local importance. The principal manufacture consists of coarse cotton cloth and cotton strips for use as turbans. In the northern glens blankets are largely made from sheep's wool. The domestic art of embroidering silk on cotton cloth attains a higher degree of excellence than in any other part of the Province or the Pun$\mathrm{jab}$, and jewellery of silver and enamel is produced. Watermills are used to a considerable extent for grinding flour and husking rice.

Commerce Cotton piece-goods, indigo, salt, tobacco, and iron are imand trade.

ported from Rāwalpindi and the south, and a large proportion goes through to Kashmīr and Bājaur, whence the chief imports are wood, fibres, and $g h \bar{i}$. Grain, chiefly maize, is exported to the dry tracts west of Rāwalpindi; to the Khattak country across the Indus, and to Peshāwar; a large part is bought direct from the agriculturists by Khattak merchants who bring their own bullocks to carry it away. $G h \bar{z}$ is exported chiefly to Peshāwar, and sheep and goats are sent to Peshāwar and Rāwalpindi.

Means of No railways pass through the District. It contains 90 miles communication.

of metalled roads under the Public Works department, and I, I 57 miles of unmetalled roads, of which 406 are under the Public Works department and the rest are managed by the District board. The principal route is the metalled road from Hassan Abdāl in Attock on the North-Western Railway, which passes through Abbottābād and Mānsehra to Srīnagar in Kashmīr, crossing the Kunhār, Kishangangā, and Jhelum rivers by iron suspension bridges. Another route, not passable for wheeled traffic, connects Abbottābād with the hill station of Murree. Both routes run through mountainous country, but are kept in excellent repair, though the latter is in winter blocked with snow. A third road, from Hazro to Haripur and Abbottābād, is chiefly used by Pathān traders from Peshāwar. A tonga and bullock train service connects Hassan Abdāl on the North-Western Railway with Abbottābād. The Kunhār is crossed by several wooden bridges.

Famine. Hazāra suffered great scarcity in the memorable and widespread famine of $\mathrm{I}_{78}$, which affected it with the same severity as the remainder of Northern India. During the decade $186 \mathrm{r}$ to 1870 , which was a period of dearth in the plains Districts, the harvests of Hazāra produced an excellent yield, and the high price of grain for exportation gave large profits to the 
peasantry, besides affording an incentive to increased cultivation. In $1877-8$, Hazāra again experienced scarcity ; but in 1879-80 the yield was abundant, and high prices ruled during the continuance of the Afghann War. The District was not seriously affected by the famines of $1896-7$ and $1899-1900$.

The District is divided for administrative purposes into District three tahsīls-Abbottābād, Harīpur, and Mānsehra-each subdiviunder a tahsildār and naīb-tahsīldār. The Deputy-Commis-staff. sioner, besides holding executive charge of the District, is Political officer in charge of the tribes of the adjacent independent territory. He has under him a District Judge who is usually also Additional District Magistrate, an Assistant Commissioner who commands the border military police, and two Extra Assistant Commissioners, one of whom is in charge of the District Treasury. The Forest division is in charge of a Deputy-Conservator.

The Deputy-Commissioner as District Magistrate is respon- Civil jussible for criminal justice, and civil judicial work is under the tice and District Judge. Both officers are supervised by the Divisional and Sessions Judge of the Peshāwar Civil Division. The District Munsif sits at Abbottābād. Crime in Hazāra is very. light for a frontier District.

Sikh rule in Hazāra began in $18 \times 8$. As in the Punjab Land generally, the only limit to the rapacity of the kardärs was the revenue. fear of imperilling future realizations, but up to this limit they exacted the uttermost farthing. Some parts of Hazāra were too barren or too inaccessible to be worth squeezing, and it may be doubted whether the Sikhs actually collected more than one-third of the total grain produce. When Major Abbott made the first summary settlement of Hazāra in r $847-8$, he took one-third as the fair share of Government. Records and measurements he neither found nor made, but he assessed each village after comparison of what it had paid with its degree of impoverishment. The Sikh demand was reduced by 16 per cent. In $185^{2}$ Major Abbott made a second summary settlement, which was in effect a redistribution of the first, and was less by Rs. 3,000 than his original demand of Rs. 2,06,000. The fact that the first assessment was easily paid is evidence of its equity, while the fact that it was reimposed, after a fall in prices quite unprecedented in both suddenness and extent, points to the improvement which must have taken place in the cultivation and the general circumstance of the District.

The assessment of $185^{2}$ remained in force for twenty years, 
and a regular settlement was carried out between 1868 and 1874. The prosperity of the District had advanced rapidly, and the demand was increased by 34 per cent. to 3 lakhs. The District again came under settlement in $190 \mathrm{r}$, when a similar rise in prosperity had to be taken into account. The new demand shows an increase of Rs. 20,400 , or 7 per cent. over the demand for $1903-4$.

The total collections of revenue in the District and those of land revenue alone are shown below, in thousands of rupees :-

\begin{tabular}{|lc|c|c|c|c|c|}
\hline & & $1880-1$. & $1890-1$. & $1900-1$. & $1903-4$. \\
\cline { 1 - 1 } \cline { 5 - 6 } L.and revenue & $\cdot$ & 2,23 & 2,26 & $3,34^{*}$ & 2,40 \\
Total revenue & $\cdot$ & 2,90 & 3,10 & $5,35^{*}$ & 3,19 \\
\hline
\end{tabular}

* Including collections from the Attock tahsil, which then formed part of the Dist rict.

Local and municipal.

The District contains five municipalities, Harīpur, ABBottāBĀD, BAFFa, MĀNSEHRA, and NaWĀShaHr; and a 'notified area,' Nathia and Dungā Galis. Outside these municipal areas, local affairs are managed by the District board, all the members of which are appointed. Its income, derived mainly from a cess on the land revenue, amounted in $1903-4$ to Rs. 29,500 ; and the expenditure was about the same, the principal item being education.

Police and The regular police force consists of 487 of all ranks, of jails. whom 42 are cantonment and municipal police. The force is controlled by a Superintendent. The village watchmen number $47 \mathrm{I}$. There are 16 police-stations, one outpost, and I 2 road-posts. The District jail at head-quarters has accommodation for I 14 prisoners. The border military police, numbering 250, are under the control of the Deputy-Commissioner exercised through the commandant, an Assistant Commissioner, and are distinct from the District police.

Education. Only 2.4 of the District population could read and write in 1901 , the proportion of males being 4.35 , and of females I per cent. Education is most advanced among Hindus and Sikhs. The number of pupils under instruction was 872 (in public schools alone) in $1880-r, 8,006$ in $1890-I, 5,264$ in $1902-3$, and 5,439 in 1903-4. In the last year there were 6 secondary and 33 primary (public) schools, and 18 advanced and 165 elementary (private) schools, with 103 female pupils in the public and 161 in the private schools. The District is very backward in education. Only 6 per cent. of 
children of a school-going age are receiving instruction. Some progress, however, is being made, and there are two Anglovernacular high schools at Abbottābād. The total expenditure on education in 1903-4 was Rs. 24,000 , of which the District fund contributed Rs. 8,000, municipalities Rs. 6,000, and fees Rs. 4,000.

The District possesses five dispensaries, at which 83,264 cases Hospitals were treated in 1904, including 1,266 in-patients, and 2,698 and disoperations were performed. The expenditure was Rs. II,500, pensaries. the greater part of which was contributed by Local funds.

In $1903-4$ the number of persons successfully vaccinated Vaccinawas 10,574 , or 19.5 per 1,000 of the population.

[District Gazetteer, 1875 (under revision).]

Abbottābād Tahsil. - Tahsīl of Hazāra District, NorthWest Frontier Province, lying between $33^{\circ} 49^{\prime}$ and $34^{\circ} 22^{\prime} \mathrm{N}$. and $72^{\circ} 55^{\prime}$ and $73^{\circ} 31^{\prime}$ E., with an area of 715 square miles. It is bounded on the east by the Jhelum, which divides it from Pünch and the Punjab District of Rāwalpindi; and it comprises part of the mountain valleys drained by the Dor and Harroh rivers, together with the hill country eastward. The hill-sides to the north and north-east are covered with timber forest. The population was 194,632 in 1901 , compared with 175,735 in I89r. It contains the towns of АввоттĀBĀD (population 7,764 ), the tahsil and District head-quarters, and NAwĀSHAHR $(4,114)$; and 359 villages. The land revenue and cesses amounted in $1903-4$ to Rs. 97,000 .

Haripur Tahsīl. - Tahsīl of Hazāra District, North-West Frontier Province, lying between $33^{\circ} 44^{\prime}$ and $34^{\circ} \mathrm{I} 8^{\prime} \mathrm{N}$. and $72^{\circ} 33^{\prime}$ and $73^{\circ} 14^{\prime} \mathrm{E}$., with an area of 657 square miles. It is bounded on the north-west by the Indus. The tahsil consists of a sloping plain, from $r, 500$ to 3,000 feet high, through which the Siran and Harroh flow. Low hills are dotted here and there over the plain. The population was 151,638 in 1901 , compared with 142,856 in $189 \mathrm{r}$. It contains the town of HARİPUR (population, 5,578 ), the head-quarters, and $3 \mathrm{II}$ villages. The land revenue and cesses amounted in 1903-4 to Rs. 1,72,000.

Mānsehra Tahsīl (Mānsahra).—Tahsīl of Hazāra District, North-West Frontier Province, lying between $34^{\circ} 14^{\prime}$ and $35^{\circ}$ ro $\mathrm{N}$. and $72^{\circ} 55^{\prime}$ and $74^{\circ} 6^{\prime}$ E., with an area of 1,486 square miles. Shaped like a cone, the tahsil runs in a northeasterly direction, comprising the deep glen of Kāgann and the mountain ranges on either hand. The population was 182,396 in 1901, compared with 165,312 in 1891 . The tahsil contains the town of BAFFA (population, 7,029) and 244 villages, 
including the large village of Mãnsehra, its head-quarters. The land revenue and cesses amounted in $1903-4$ to Rs. $1,03,000$. The AGROR valley is situated in this tahsil.

Tanāwal (Tunāzual).-A tract of mountainous territory in the extreme north-west corner of Hazãra District, NorthWest Frontier Province, lying on the east of the Indus, between $34^{\circ} 15^{\prime}$ and $34^{\circ} 23^{\prime} \mathrm{N}$. and $72^{\circ} 5^{\prime}$ and $73^{\circ} 10^{\prime} \mathrm{E}$. The Siran river flows through it from north to south. In the latter part of Akbar's reign Tanãwal was overrun by the Yūsufzai Pathāns, and it is still partly peopled. by Afghāns; but it became nominally a dependency of Kashmīr under the Durrānis. Its real rulers, however, were the Tanāwalis, a tribe of Mughal descent divided into two septs, the Pul-âl and Hando-āl or Hind-wāl. The former held the tract east of the Siran; and its chief founded Birr when the Mughal power was decaying, but internal dissensions led to the intervention of the governor of Kashmir. Meanwhile, the Hind-wāl sept had gained power and its chief Nawāb Khān defied the Durrānis, but met his death at the hands of Sardār Azim Khān in $r 8 r 8$. His son, Painda Khān, played a considerable part in the history of his time and vigorously opposed the Sikhs, but lost all his territory except the tract round Amb. On his death in 1840 his son, Jahāndād Khān, recovered part of it through the favour of Gulāb Singh of Kashmïr and the British Government. Thus the present semi-independent estate comprises the territory formerly held by the Hind-wāl Tanāwalis. It has an area of 204 square miles, with a population (I9OI) of 31,622 . It is bounded on the north by the Black Mountain, on the west by the Indus, on the south by the Harippur and Abbottābād tahsills, and on the east by the Mānsehra tahsil of Hazāra District. It belongs partly to Nawāb Sir Muhammad Akram Khān, K.C.S.I., chief of Amb, and partly to Atā Muhammad Khān, Khān of Phulra. Since the annexation of Hazāra, the administration of Tanāwal has been practically in the hands of these chiefs, their authority being legally defined by Regulation II of 1900 , by which civil, criminal, and revenue administration is vested in them, the only exceptions being offences against the state and murder. Both the chief of Amb and the Khān of Phulra are Tanāwalis of the Hind-wāl section, the former being a grandson of Painda Khān, and the latter a great-grandson of Madad Khān, younger brother of Painda Khān.

The title of Nawāb was bestowed on Muhammad Akram Khān in I868, partly as a reward for his father's services in the 
Mutiny, and partly in recognition of his personal courage and loyalty in the Hazāra expedition of 1868 . At the same time he received a cash allowance of Rs. 500 a month, which he has enjoyed ever since. In $\mathrm{r} 87 \mathrm{I}$ he became a C.S.I., and in 1889 a K.C.S.I. He also enjoys a jaggir of the annual value of Rs. 9,000 in the Haripur tahsill of Hazāra District. Amb, the place from which he takes his title, is situated on the western bank of the Indus, in his independent territory, and is a winter residence, his summer head-quarters being at Shergarh near the eastern extremity of Upper Tanāwal.

Abbottābād Town.-Head-quarters of Hazāra District, and also of the Abbottābād tahsīl, North-West Frontier Province, situated in $34^{\circ} 9^{\prime} \mathrm{N}$. and $73^{\circ} \mathrm{r} 3^{\prime} \mathrm{E}$. Population (r9or), 7,764. The head-quarters of the District were fixed here in 1853, and the new cantonment was named after Major James Abbott, first Deputy-Commissioner of Hazāra, 1847-53. The town is picturesquely situated at the southern corner of the Răsh (Orāsh) plain, 4,120 feet above the sea. The garrison consists of 4 battalions of native infantry (Gurkhas) and 4 native mountain batteries. The municipality was created in 1867 . The income during the ten years ending 1902-3 averaged Rs. 14,900 , and the expenditure Rs. $\mathrm{r}_{4}, 000$. In $1903-4$ the income was Rs. 22,300, chiefly derived from octroi, and the expenditure Rs. 18, 100. The receipts and expenditure of cantonment funds during the ten years ending 1902-3 averaged Rs. 7,300. The chief public institutions are the Albert Victor unaided Anglo-vernacular high school, a municipal Anglo-vernacular high school, and a Government dispensary.

Agror.-Frontier valley in the Mānsehra tahsill of Hazāra District, North-West Frontier Province, lying between $34^{\circ} 29^{\prime}$ and $34^{\circ} 35^{\prime} \mathrm{N}$. and $72^{\circ} 5^{\prime}$ and $75^{\circ} 9^{\prime} \mathrm{E}$. It consists of three mountain glens, Io miles in length and 6 in breadth. The lower portions contain a mass of luxuriant cultivation, thickly dotted with villages, hamlets, and groves, and surrounded by dark pine-clad heights, whose depressions occasionally disclose the snowy peaks of the main range in the distance. These valleys are alike in their nature; they have no strictly level spaces, but consist rather of terraced flats which descend from the hills. Water is abundant and perennial, so that failure of crops seldom occurs. The population chiefly consists of Swātis and $\mathrm{Gu}$ uars, and was returned in I901 at 16,983 . Islām is the almost universal creed. Agror is the ancient Atyugrapura of

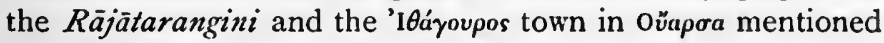
by Ptolemy. From the time of Tìmūr until the beginning of 
the eighteenth century the Agror valley was held by a family of Karlugh. Turks. These were expelled in $\times 703$ by a Saiyid named Jalāl Bāba, and the conquered country was divided among the Swātis, one Ahmad Sad-ud-dīn, who died in $\times 78_{3}$, rising to the position of Khān of Agror. The Nawāb of Amb took the valley in 1834 , but in $184 \mathrm{r}$ it was restored by the Sikhs to Atā Muhammad, a descendant of Sad-ud-dīn. At annexation Atā Muhammad was recognized as chief of Agror, and the defence and management of this part of the frontier was originally left to him; but the arrangement did not work satisfactorily. An expedition had to be sent in 1852 to avenge the murder of two officers of the Salt department; and in consequence of the unsatisfactory attitude of the chief and of repeated complaints by the cultivators, it was resolved in 1868 to place a police station in Agror and to bring the valley more directly under the administration of Government. This incensed the Khān, at whose instigation the newly built police station was burnt by a raid of the Black Mountain tribes. An expedition was dispatched, and Atā Muhammad was deported to Lahore for a time, but in 1870 reinstated in his chieftainship. His son and successor, Ali Gauhar, was removed from the valley in r 888 in consequence of his abetting raids into British territory. In order to maintain the peace of the border, expeditions were dispatched against the Black Mountain tribes in 1888 , r89r, and $\times 892$; and there has since been no disturbance. The Agror Valley Regulation (1891) declared the rights of the Khān of Agror forfeit to Government.

The land revenue of the valley was assessed by the Sikhs at Rs. I,515. This demand was continued on annexation, and raised to Rs. 3,315 in 1853 and Rs. 4,000 in the regular settlement, in which the engagement was made with the Khān. The settlement was revised in 1901, and the present demand is Rs. 13,300 .

The sole manufacture of the valley is cotton cloth, and trade is purely local, except for a small export of grain. The chief place in the valley is the village of Oghi, the head-quarters of the Hazāra border military police.

Baffa.-Town in the Mānsehra tahsīl of Hazāra District, North-West Frontier Province, situated in $34^{\circ} 26^{\prime} \mathrm{N}$. and $73^{\circ} \mathrm{r} 3^{\prime} \mathrm{E}$., on the right bank of the Siran river in the northern corner of the Pakhli plain. Population (r901), 7,029. This is the principal mart of Northern Hazara and of the neighbouring independent tracts. The municipality was created in 1873. The income during the ten years ending $1902-3$ 
averaged Rs. 4,500 and the expenditure Rs. 4,600. In 1903-4 the income was Rs. 5,300, chiefly derived from octroi, and the expenditure was Rs. 4,700. A vernacular middle school is maintained by the municipality and the District board.

Bara Gali.-Small cantonment in Hazãra District, NorthWest Frontier Province, situated in $34^{\circ} 10^{\circ} \mathrm{N}$. and $73^{\circ} 30^{\prime} \mathrm{E}$., on the road between Abbottābād and Murree, I 5 miles from Abbottābād and 25 from Murree. During the summer months it is occupied by one of the British mountain batteries which are stationed at Rāwalpindi in the winter.

Chāngla Gali.-Small hill station in the Abbottābād tahsil of Hazāra District, North-West Frontier Province, situated in $34^{\circ} \mathrm{o}^{\prime} \mathrm{N}$. and $73^{\circ} 23^{\prime} \mathrm{E}$., on the road from Murree to Abbottàbād. 'It is the head-quarters of the Northern Command School of Musketry.

Dungā Gali-Small sanitarium in the Abbottābād tahsīl of Hazāra District, North-West Frontier Province, situated in $34^{\circ} 6^{\prime} \mathrm{N}$. and $73^{\circ} 25^{\prime} \mathrm{E}$. A few houses are scattered over the southern slopes of the Makshpuri hill, belonging to Europeans who visit the place during the summer. Dungā Gali contains an hotel, a post office, and a small church. Together with Nathia GaLI it forms a 'notified area.'

Ghora Dakka.-Small cantonment in Hazāra District, North-West Frontier Province, situated in $34^{\circ} 2^{\prime} \mathrm{N}$. and $73^{\circ} 25^{\prime} \mathrm{E}$., on the road between Dungā Gali and Murree, 3 miles from the former and 15 from the latter place. During the summer months it is occupied by a detachment of British infantry.

Haripur Town.-Head-quarters of the Haripur tahsil of Hazāra District, North-West Frontier Province, situated in $34^{\circ} \mathrm{N}$. and $72^{\circ} 57^{\prime} \mathrm{E}$., on the left bank of the Dor river, and on the road from Hassan Abdāl to Abbottābād. Population (I9or), 5,578. Harīpur was founded about 1822 by Sardār Harī Singh, the Sikh governor of Hazāra, and on annexation became the head-quarters of the District, but was abandoned in favour of Abbottābād in I 853. An obelisk marks the grave of Colonel Canara, a European officer of the Sikh artillery, who fell in 1848 defending his guns single-handed against the insurgents under Chattar Singh. The municipality was constituted in 1867 . The income and expenditure during the ten years ending $1902-3$ averaged Rs. 17,800 . In $1903^{-4}$ the income and expenditure were Rs. 19, 100 and Rs. 20, 100 respectively. The town possesses a dispensary and a municipal middle school. 
Kāgān $(K \bar{h} \bar{g} g \bar{a} n)$.-Mountain valley in Hazāra District, North-West Frontier Province, penetrating far into the heart of the Himālayan system, and surrounded by Kashmir territory on every side except the south. The valley has an area of 800 square miles, and is 60 miles in length, with an average breadth of 15 miles. Lofty ranges shut it in on either hand, their summits rising to a height of 17,000 feet. Transverse spurs intersect the valley, which is inhabited by a sparse population. Kāgān comprises twenty-two rakhs or forest and grazing Reserves, with a total area of 90 square miles, while the area of 'reserved' and unreserved forest is 457 square miles. The rights of cutting grass and grazing cattle are leased out annually. The Forest department only fells timber, which is launched into the river Kunhār, caught at different timber dépôts, and rafted to Jhelum. The river Kunhār forces its way through a narrow central gorge to join the Jhelum after draining the entire valley. The Kāgān valley forms the northernmost extension of British India, and stretches far up into the mountain region. Its open mouth turns towards the main body of Hazãra District. The inhabitants consist almost entirely of Muhammadan Swātis and Gūjars. Kāgān village is situated in $34^{\circ} 46^{\prime} \mathrm{N}$. and $75^{\circ} 34^{\prime} \mathrm{E}$.

Kālābāgh.-Small cantonment in Hazāra District, NorthWest Frontier Province, situated in $34^{\circ} 6^{\prime} \mathrm{N}$. and $73^{\circ} 25^{\prime} \mathrm{E}$., on the road between Abbottābād and Murree. During the summer months it is occupied by one of the British mountain batteries which are stationed at Rāwalpindi in the winter.

Khaira Gali.-Small cantonment in Hazāra District, NorthWest Frontier Province, situated in $33^{\circ} 55^{\prime} \mathrm{N}$. and $73^{\circ} 20^{\prime} \mathrm{E}$., on the road between Abbottābād and Murree. During the summer months it is occupied by one of the British mountain batteries which are stationed at Rāwalpindi in the winter.

- Khanspur.-Part of the Ghora Dakka cantonment in Hazāra District, North-West Frontier Province, situated in $34^{\circ} 2^{\prime} \mathrm{N}$. and $73^{\circ} 30^{\prime} \mathrm{E}$. During the summer months it is occupied by a detachment of British infantry.

Mānsehra Town (Mänsahra).-Head-quarters of the tahsil of the same name, Hazāra District, North-West Frontier Province, situated in $34^{\circ} 20^{\prime} \mathrm{N}$. and $73^{\circ} \mathrm{r} 3^{\prime} \mathrm{E}$., on the right bank of an affluent of the Siran, north of Abbottābād, and on the main road from Kāla-ki-Sarai to the Kashmīr border. Population (I90I), 5,087. A few resident Khattri traders do a considerable business in grain and country produce. The chief institutions are an Anglo-vernacular middle school 
maintained by the District board, and a Government dispensary. Near the town are two rocks on which are inscribed in the Kharoshthi character thirteen of the edicts of Asoka.

Nathia Gali.-Hill station in the Abbottābād tahsil of Hazāra District, North-West Frontier Province, and summer head-quarters of the Chief Commissioner, situated in $34^{\circ} 5^{\prime} \mathrm{N}$. and $73^{\circ} 5^{8^{\prime}} \mathrm{E}$., on the road from Murree to Abbottābād, about half-way between each place. Together with Dungā Gali it constitutes a 'notified area' under the Punjab Municipalities Act, 1891, of which the income in 1903-4 was Rs. 3,000, chiefly-derived from a house tax. The expenditure was Rs. I,900.

Nawāshahr.-Town in the Abbottābād tahsīl of Hazāra District, North-West Frontier Province, situated in $34^{\circ} \mathrm{Io}^{\prime} \mathrm{N}$. and $73^{\circ} 16^{\prime}$ E., about 3 miles east of Abbottābād. Population (190r), 4, rr4. Before the foundation of Abbottābād, it was the chief town of the Rāsh plain. The municipality was created in 1867 . During the ten years ending 1902-3 the income averaged Rs. 2,600, and the expenditure Rs. 2,500. In 1903-4 the income was Rs. 2,700, chiefly derived from octroi, and the expenditure was Rs. 2,800.

Oghi $(U g h i) .-$ Chief place in the Agror valley, Hazāra District, North-West Frontier Province, and head-quarters of the Hazāra border military police. There is a Government dispensary.

Thandiāni.-Small hill sanitarium in the Abbottābād tahsīl of Hazāra District, North-West Frontier Province, situated in $34^{\circ} 15^{\prime} \mathrm{N}$. and $73^{\circ} 22^{\prime} \mathrm{E}$. It was established for the convenience of officers stationed at the neighbouring cantonment of Abbottābād, and contains some European houses and a small bazar, which are occupied only during the summer months.

Peshāwar District.-District in the North-West Frontier BounProvince, and the most north-western of the regularly ad- daries, conministered Districts in the Indian Empire. It lies between and hill $33^{\circ} 43^{\prime}$ and $34^{\circ} 32^{\prime} \mathrm{N}$. and $71^{\circ} 22^{\prime}$ and $72^{\circ} 45^{\prime}$ E., with an and river area of 2,61 I square miles. It is bounded on the east by the Indus, which separates it from the Punjab District of Attock and from Hazāra. On all other sides it is encircled by mountains, at the foot of which, except on the south-east, the administrative border runs. These hills are inhabited by independent tribes, whose territories lie in the following order, beginning from the north-east corner, where the boundary leaves the river. The Utmanzai, Gadun, Khudu Khel, and Salarzai 
clans are hamsāyas of the Bunerwāls; north of Mardān lies a small piece of Utman Khel country, west of which is Sam Rānizai sloping up to the Malakand Pass; beyond Sam Rānizai comes the main Utman Khel country, which stretches as far as Abāzai on the Swāt river; the country between the Swāt and Kābul rivers belongs to the Burhān Khel, Halimzai, and Tarakzai Mohmands ; from the Kābul river to Jamrūd at the mouth of the Khyber Pass is Mullagori country; the hills between the Khyber and the Kohāt Pass are the abode of the Malikdīn and Akā Khel Afrīdis; on both sides of the Kohāt Pass live the tribes known as the Pass Afridis, beyond whom on the south side of the District live the Jowakis, whose territory runs nearly as far as Cherāt. East of Cherāt the range is inhabited by Khattaks, and forms, except for the Khwarra and Zira forest on the banks of the Indus, part of Kohāt District. To the north-east great spurs, separated by intricate lateral valleys, run into the District, the Mora, Shākot, and Malakand Passes leading through them into Swāt. From the north-west outlying ranges of the Hindu Kush run down the western border, loftily isolated peaks to the north merging in the confused and precipitous heights on the south bank of the Kābul river. South of the Khyber, the range sinks to a mean level of 4,000 feet, and at the point where the Kohăt Pass leads out of the District turns sharp to the east, and runs along the south border of the District to the Indus. On this side the highest points are Cherāt, with an elevation of nearly 4,500 feet, and the Ghaibāna Sir, $5,13^{6}$ feet above sea-level. The shape of the District is an almost perfect ellipse, the greatest length of which is 86 miles, its greatest width being 54 miles.

Viewed from a height it appears a vast plateau, whose vivid expanse of green is in abrupt contrast with the grey precipitous slopes of the hills which rise sharply from its edge; but its true formation is that of a huge basin into which flow the waters from the surrounding hills. This basin is drained by the Kābul river, which traverses the valley eastwards from its debouchure through a deep ravine north of the Khyber Pass until it falls into the Indus above Attock. Throughout its course the Kābul is joined by countless tributaries, of which the principal is the Swāt ; and before they unite below Prāng (Chārsadda), about 24 miles from the hills, these two rivers cover the central part of the "western plain with a perfect network of streams, as each divides into several channels. 'The Bārā, flowing from the south-west, also enters the Kābul 
near its junction with the Swāt; and the united stream, now known as the Landai, or 'short river,' flows for 12 miles in a wide bed as far as Naushahra, and thence for 24 miles in a deep channel to the Indus. Other streans are the Budni, a branch of the Kābul; and the Kalpāni or Chalpānî, the 'deceitful water,' which, rising beyond the Mora pass, receives the drainage of the Yūsufzai plain and falls into the Landai below Naushahra.

Peshāwar has not been geologically surveyed, but the Geology? general structure of the District appears to be a continuation westwards of that of Hazāra. Judging from partial traverses and from information of various kinds, one may say that its northern portions, including the hills on the northern border, are composed, like Hazāra, of metamorphic schists and gneissose rocks. Much of the flat plain of Peshāwar and Naushahra and the northern slopes of the Cherāt hills consist of a great slate series with minor limestone and marble bands, some of which are worked for ornamental purposes. South of the axis of the Cherāt range, the rest of the District is apparently composed of a medley of folded representatives of the Jura Cretaceous and Nummulitic formation. They consist of limestones, shales, and sandstones of marine origin, the general strike of the rock bands being east and west across the Indus in the direction of Hazāra and Rāwalpindi. Much of the valley of Peshāwar is covered by surface gravels and alluvium, the deposit of the streams joining the Käbul river on its way to the Indus.

The District, wherever irrigated, abounds in trees, of Botany. which the mulberry, shisham, willow, tamarisk, and tallowtree are the most common. In the drier parts scrub jungle grows freely, but trees are scarce, the palosi or ber being the most frequent. The more common plants are Flacourtia sapida, F. sepiaria, several species of Grewia, Zizyphus nummularia, Acacia Jacquemontii, A. leucophloea, Alhagi camelorum, Crotalaria Burhia, Prosopis spicigera, several species of Tamarix, Nerium odorum, Rhazya stricta, Calotropis procera, Periploca aphylla, Tecoma undulata, Lycium europaeum, Withania coagulans, W. somnifera, Nannorhops Ritchieana, Fagonia, Tribulus, Peganum Harmala, Calligonum polygonoides, Polygonum aviculare, $P$. plebejum, Rumex vesicarius, Chrozophora plicata, species of Aristida, Anthistiria, Cenchrus, and Pennisetuin.

1 W. Waagen, 'Section along the Indus from the Peshāwar Valley to the Salt Range,' Records, Geological Survey of India, vol. xvii, part iii.

XW.F.P. 
Fauna.

The fauna is meagre. Märkhor are found on the Pajja spurs which jut out from the hills north of Mardān, and occasionally near Cherāt, where uriāl are also seen. Wolves and hyenas are now not numerous, but leopards are still met with, though rarely. The game birds are those of the Northern Punjab ; and though hawking and snaring are favourite amusements of the people and many possess firearms, wild-fowl of all the migratory aquatic species, including sometimes wild swans, abound in the winter. Non-migratory species are decreasing as cultivation extends. The Peshāwar Vale Hunt maintains an excellent pack of hounds, the only one in Northern India, and affords capital sport to the large garrison of Peshāwar. There is fishing in many of the streams near the hills.

Climate and temperature.

The best time of the year is the spring, February to April being the months when the air, though cold, is bracing. December and January are the coldest months, and the temperature sometimes falls below $30^{\circ}$ and the nights are intensely cold. During the hot season, from May to July, the air is full of dust-haze. Dust-storms are frequent, but though thunderstorms occur on the surrounding hills, rain seldom falls in the plains. This season is, however, healthy, in contrast to the next months, August to October, when the hot-season rains fall and the air is stagnant and oppressive. After a fall of rain the atmosphere becomes steamy and fever is common. In November the days are hot owing to the clear atmosphere, but the nights are cold. Showers are usual during winter. Inflammatory diseases of the lungs and bowels and malarial fever are prevalent at this season. The principal disease from which the valley, and especially the western half of it, suffers is malarial fever, which in years of heavy rainfall assumes a very deadly form, death often supervening in a few hours.

Rainfall. The annual rainfall varies from II inches at Chārsadda to $I 7 \frac{1}{2}$ at Mardān. Of the total at Mardān, II inches fall in the summer and $6 \frac{1}{2}$ in the winter. The heaviest rainfall during the last twenty years was 35 inches at Mardān in I882-3, and the lightest 3 inches at Kătlang in I883-4.

History and archaeo. $\log y$. appears in Sanskrit literature is GANDHĀRA, corresponding to the Gandarites of Strabo and the country of the Gandarae described by Ptolemy, though Arrian speaks of the people who held the valley against Alexander as Assakenoi. Its capital, Peukelaotis (or Pushkalāvati), is mentioned by Arrian 
as a large and populous city, captured by Hephaistion, the general of Alexander, after the death of its chieftain Astes. The site of Pushkalāvati has been identified with Chārsadda, where extensive mounds of ancient débris are still to be seen. The Peshāwar and Kābul valleys were ceded by Seleucus to Chandragupta in 303 B.C., and the rock edicts of Asoka at Mānsehra and Shāhbāzgarhi show that Buddhism had become the state religion fifty years later. The Peshāwar valley was annexed by the Graeco-Bactrian king Eucratides in the second century, and about the beginning of the Christian era fell under the rule of the Kushans. It is to the intercourse between the Greeks and the Buddhists of this part of India that we owe that school of art known as Graeco-Buddhist, and this in turn served as the source of much that is fundamental in the ecclesiastical art of Tibet, China, and Farther Asia generally. For it was in this District that the Mahãyanna school of Buddhism arose, and from it that it spread over the Asiatic continent. Buddhism was still the dominant religion when $\mathrm{Fa}$ Hian passed through in the fifth century A.D. Sung Yun, who visited Peshāwar in 520 , mentions that the Ephthalite king of Gandhãra was at war with the king of Kābul, but at the time of Hiuen Tsiang's visit in $63^{\circ}$ Gandhāra was a dependency of Kābul. Buddhism was then falling into decay.

Until the middle of the seventh century, epigraphic evidence shows that the population remained entirely Indian, and Hinduized rulers of Indo-Scythian and Turkish descent retained possession of Peshāwar itself and of the Hashtnagar and Yūsufzai plains. They were succeeded by the so-called Hindu Shāhis of Kābul or Ohind. In 979 one of these, Jaipāl, advanced from Peshāwar to attack Sabuktagīn, governor of Khorāsān under the titular sway of the Sāmāni princes, but peace was effected and he retired. Nine years later Jaipāl was utterly defeated at Laghmān, and Sabuktagīn took possession of Peshāwar, which he garrisoned with 10,000 horse. On his death in 998, his son Mahmūd succeeded to his dominions, and, throwing off his nominal allegiance to the Sāmāni dynasty, assumed the title of Sultān in 999. In Ioo6 Mahmūd again invaded the Punjab; and on his return Jaipāl's son and successor, Anandpāl, attempted to intercept him, but was defeated near Peshāwar and driven into Kashmīr. But he was able to organize further resistance, for in 1009 he again encountered Mahmūd, probably at Bhatinda, on the Indus, where he met with his final overthrow. The Ghaznivid monarchy in turn fell before Muhammad of Ghor in IISr; 
and after his death in 1206 the provincial governors declared their independence, making the Indus their western boundary, so that the Peshãwar valley was again cut off from the eastern kingdom. In 1221 the Mongols under Chingiz Khãn established a loose supremacy over it. About the close of the fifteenth century, a great tide of Afghān immigration flowed into the District. Before Tĩmūr's invasion the Dilazāks had been settled in the Peshāwar valley, in alliance with the Shalmanis, a Tãjik race, subjects of the rulers of Swāt. The Khākhai (Khashi) Pathāns, a body of roving adventurers, who first come into notice in the time of Tìmūr, were, treacherously expelled from Kābul by his descendant Ulugh Beg, whereupon they entered the Peshāwar valley in three main clans-the Yũsufzai, Gigiānis, and Muhammadzai-and obtained permission from the Dilazāks to settle on a portion of their waste lands. But the new immigrants soon picked a quarrel with their hosts, whom they attacked.

In $15 \times 9$ Bābar, with the aid of the Dilazāks, inflicted severe punishment on the Yusufzai clans to the north of the District, but before his death (1530) they had regained their independence, and the Dilazăks even dared to burn his fort at Peshāwar. The fort was rebuilt in $\mathbf{1} 553$ by Bābar's successor, Humāyūn, after defeating his brother Mirza Kamrān, who had been supported against Humāyũn by the Ghorai Khel tribes (Khalils, Daudzai, and Mohmands) now first heard of in connexion with Peshāwar. After his victory Humāyūn returned to Hindustān. On his departure the Ghorai Khel entered into alliance with the Khakhai Khel, and their united forces routed the Dilazāks and drove them out of the District across the Indus. The Ghorai Khel and Khakhai Khel then divided the valley and settled in the portions of it still occupied by them, no later tribal immigration occurring to dispossess them.

The Khalils and a branch of the Mohmands took the southwest corner of the District; to the north of them settled the Daudzai; the remaining Mohmands for the most part stayed in the hills, but settlers gradually took possession of the triangle of land between the hills and the Swăt and Kābul rivers; the east portion of the District fell to the Khakhai Khel: namely, to the Gigiānis and Muhammadzai, Hashtnagar; and to the Yūsufzai and Mandanrs, Mardān and Swãbi and the hill country adjoining.

In the next century the Mandanrs were driven from the hills by the Yūsufzai, and concentrated in the east portion of the 
Peshâwar valley, whence they in turn expelled the Yūsufzai. Peshāwar was included in the Mughal empire during the reigns of Akbar, Jahāngīr, and Shāh Jahān; but under Aurangzeb a national insurrection was successful in freeing the Pathān tribes from the Mughal supremacy.

In 1738 the District fell into the hands of Nādir Shāh; and, under his successors, Peshāwar was often the seat of the Durrāni court. On the death of Tīmūr Shāh in I 793, Peshāwar shared the general disorganization of the Afghan kingdom; and the Sikhs, who were then in the first fierce outburst of revenge upon their Muhammadan enemies, advanced into the valley in 1818 , and overran the whole country to the foot of the hills. In 1823 , Azīm Khān made a last desperate attempt to turn the tide of Sikh victories, and marched upon Peshāwar from Kābul; but he was utterly defeated by Ranjit Singh, and the whole District lay at the mercy of the conquerors. The Sikhs, however, did not take actual possession of the land, contenting themselves with the exaction of a tribute, whose punctual payment they ensured or accelerated by frequent devastating raids. After a period of renewed struggle and intrigue, Peshāwar was reoccupied in 1834 by the Sikhs, who appointed General Avitabile as governor, and ruled with their usual fiscal severity.

In 1848 the Peshāwar valley came into the possession of the British, and was occupied almost without opposition from either within or without the border. During the Mutiny the Hindustāni regiments stationed at Peshāwar showed signs of disaffection, and were accordingly disarmed with some little difficulty in May, 1857. But the 55th Native Infantry, stationed at Naushahra and Hoti Mardān, rose in open rebellion; and on a force being dispatched against them, marched off towards the Swāt hills across the frontier. Nicholson was soon in pursuit, and scattered the rebels with a loss of 120 killed and I50 prisoners. The remainder sought refuge in the hills and defiles across the border, but were hunted down by the clans, till they perished of hunger or exposure, or were brought in as prisoners, and hanged or blown away from cannon. This stern but necessary example prevented any further act of rebellion in the District.

Peshāwar District contains 7 towns and 793 villages. The The population at each of the last three enumerations was: (I88I) people. $599,45^{2}$, (1891) 7 1 1,795, and (1901) 788,707. It increased by nearly i i per cent. during the last decade, the increase being greatest in the Mardān tahsil, and least in that of Nau- 
shahra. The District is divided into five tahszls, the chief statistics of which are given in the following table:-

\begin{tabular}{|c|c|c|c|c|c|c|c|}
\hline \multirow[b]{2}{*}{ Tahsil. } & \multirow{2}{*}{ 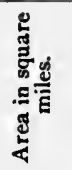 } & \multicolumn{2}{|c|}{ Number of } & \multirow{2}{*}{ 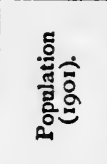 } & \multirow{2}{*}{ 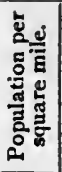 } & \multirow{2}{*}{ 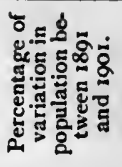 } & \multirow{2}{*}{ 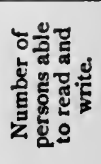 } \\
\hline & & 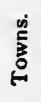 & 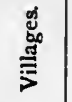 & & & & \\
\hline $\begin{array}{l}\text { Peshāwar . } \\
\text { Chārsadda } \\
\text { Mardān } \\
\text { Swābi } \\
\text { Naushahra }\end{array}$ & $\begin{array}{l}45^{r} \\
380 \\
610 \\
467 \\
703\end{array}$ & $\begin{array}{l}1 \\
3 \\
1 \\
2 \\
2\end{array}$ & $\begin{array}{r}259 \\
168 \\
130 \\
94 \\
142\end{array}$ & $\begin{array}{l}248,060 \\
142,756 \\
137,2 \text { I } 5 \\
144,5 \text { I } 3 \\
116,163\end{array}$ & $\begin{array}{l}550 \\
376 \\
225 \\
309 \\
166\end{array}$ & $\begin{array}{l}+\quad 9.7 \\
+\quad 7.4 \\
+\quad 20.5 \\
+10.6 \\
+\quad 7.3\end{array}$ & 31,247 \\
\hline District total & 2,6 II & 7 & 793 & $788,7 \circ 7$ & 302 & +10.8 & 31,247 \\
\hline
\end{tabular}

The head-quarters of each tahsil is at the place from which it is named. The chief towns are the municipality of PESHĀWAR, the administrative head-quarters of the District and capital of the Province, Naushahra, Chārsadda, Tangi, and Mardān.

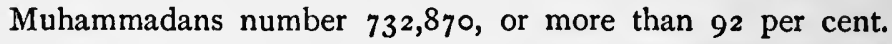
of the total ; Hindus 40,183 ; and Sikhs I I,318. The language of the people is Pashtu.

Castes and Peshāwar is as much the home of the Pathāns as Kābul, occupa- and hence we find that of the total population of the District
tions. 402,000 , or 5 I per cent., are Pathāns. They are almost entirely dependent on agriculture. Their distribution is as above described. The Khattaks are the principal tribe in the Naushahra tahsīl. Among these fanatical Pathāns, the Saiyids, descendants of the Prophet, who occupy a position of great influence, number 24,000. In the popular phraseology of the District, all tribes who are not Pathāns are Hindkīs, the most numerous being the Awāns (III,000). They are found only in the Peshāwar and Naushahra tahsils, and besides being very fair cultivators are petty traders as well. Gūjars $(16,000)$ and Bāghbāns $(9,000)$ are other Hindkī agriculturists. These tribes are all Muhammadans. Of the trading classes, Aroras $(17,000)$ and Khattrīs $(13,000)$ are the most important, and the Parāchas (carriers and pedlars, 7,000 ) come next. Of the artisan classes, the Julāhās (weavers, 19,000), Tarkhāns (carpenters, I6,000), Lohārs (blacksmiths, 8,000), Kumhārs (potters, 8,000), and Mochis (shoemakers and leather-workers, $5,000)$ are the most numerous. The Kashmiris, immigrants from Kashmir, number 9,000. Of the menial classes, the most important are the Nais (barbers, 9,000), Dhobis (washermen, 8,000), and Chūhrās and Musallis (sweepers, 8,000). The 
Mīrãsîs $(4,000)$, village minstrels and bards, and Ghulāms (300), who are chiefly engaged in domestic service and appear only in this District, are also worth mentioning. Agriculture supports 60 per cent. of the total.

The Church Missionary Society established its mission to Christian the Afghāns at Peshāwar in $\mathrm{r} 855$, and now has branches at missions. Naushahra and Mardān. It organized a medical mission in r884, and in 1894 founded the Duchess of Connaught Hospital. The Zanāna Mission has a staff of five English ladies, whose work is partly medical and partly evangelistic and educational. The Edwardes Collegiate (Mission) School, founded in 1855 , is now high school with a collegiate department attached.

With the exception of the stony tracts lying immediately General below the hills, the District displays a remarkable uniformity agriculof soil : on the surface, light and porous earth with a greater ditions. or less intermixture of sand ; and below, a substratum of strong retentive clay. The only varieties of soil are due to variations in the depth of the surface earth, or in the proportion of sand mixed with it ; and with irrigation the whole valley is capable, almost without exception, of producing the richest crops. Sandy and barren tracts occur in some few localities, but they are of small extent, and bear an insignificant proportion to the total area. The spring harvest, which in 1903-4 occupied 70 per cent. of the total area cropped, is sown chiefly from the end of September to the end of January, and the autumn harvest chiefly in June, July, and August, though sugar and cotton are sown as early as March.

The District is held almost entirely by communities of Chief agrismall peasant proprietors, large estates covering only about cultural I53 square miles. The following table shows the statistics and princiof cultivation in $1903-4$, in square miles:pal crops.

\begin{tabular}{|c|c|c|c|c|c|}
\hline Tahsil. & Total. & Cultivated. & Irrigated. & $\begin{array}{c}\text { Cultivable } \\
\text { waste. }\end{array}$ & $\begin{array}{c}\text { Not available } \\
\text { for } \\
\text { cultivation. }\end{array}$ \\
\hline $\begin{array}{l}\text { Peshāwar : } \\
\text { Chārsadda } \\
\text { Mardān : } \\
\text { Swābi } \\
\text { Naushahra }\end{array}$ & $\begin{array}{l}451 \\
380 \\
610 \\
467 \\
703\end{array}$ & $\begin{array}{l}203 \\
261 \\
409 \\
317 \\
177\end{array}$ & $\begin{aligned} & 52 \\
& \text { I } 75 \\
& \text { I } 99 \\
& 3^{8} \\
& 47\end{aligned}$ & $\begin{array}{r}157 \\
58 \\
53 \\
35 \\
259\end{array}$ & $\begin{array}{r}91 \\
61 \\
148 \\
115 \\
267\end{array}$ \\
\hline Total & 2,6 II & 1,367 & 531 & $5^{62}$ & 682 \\
\hline
\end{tabular}

The chief food-crops are wheat (555 square miles), barley $(287)$, and maize (231). Sugar-cane $\left(3^{2}\right)$ and cotton $(26)$ are also of some importance. The neighbourhood of Peshãwar 
produces apricots, peaches, pomegranates, quinces, and other fruits in great abundance; and $\mathbf{8 . 6 2}$ square miles were under fruits and vegetables in 1903-4.

Improve- The area cultivated at the settlement of $1895^{-6}$ showed an ments in agricultural practice. increase of 7 per cent. in the previous twenty years, largely due to the extension of canal irrigation in the Naushahra and Peshāwar tahsils. Since 1895-6 there has been a slight decrease in the cultivated area, which seems to show that the limits of the resources of the District in this respect have been reached. Little has yet been done towards improving the quality of the crops grown. Loans for the construction of wells and the purchase of plough cattle are readily appreciated by the people, and during the five years ending $1902-3$ an average of Rs. 9, 100 was advanced. In 1903-4 Rs. 6,460 was advanced under the Land Improvements Acts, and Rs. 5,420 under the Agriculturists' Loans Act.

Cattle, Wheeled carriages are common throughout the District, ponies, and though there is much pack traffic mainly carried on bullocks,
sheep. which are fine strong animals, much superior to those used in agriculture. Horses are not extensively reared in the valley. The Civil Veterinary department maintains a horse and seven donkey stallions, and the District board three pony and two donkey stallions. Large flocks of sheep and goats are owned by the border villages, which have extensive grazing rights on the stony plains at the foot of the hills.

Irrigation. Of the total cultivated area of the District in $1903-4,531$ square miles or 40 per cent. were irrigated. Of these, 7 I square miles were irrigated from wells, 453 from canals, and 7 from streams and tanks. In addition, 26.5 square miles, or 2 per cent., are subject to inundation. Well-irrigation is resorted to in the eastern half of the District wherever the depth of the spring-level allows. The District contains 6,389 masonry wells worked with Persian wheels by bullocks, besides 5, I 2 I unbricked wells, lever wells, and water-lifts. The most important canals of the District are the SwĀT, KĀBuL, and Bārā River Canals. The two first are under the management of the Canal department, the last-named is in charge of the Deputy-Commissioner. The Michni-Dilazāk canal, taking off from the left bank of the Kanbul river, and the Shabkadar branch canal from the right bank of the Swāt river, belong to the District board. The I)istrict also contains a large number of private canals, which are managed by the Deputy-Commissioner under the Peshãwar Canals Regulation of 1898 .

Forests. There is ample historical evidence that in ancient times the 
District was far better wooded than it is now, and the early Chinese pilgrims often refer to the luxuriant growth of trees on hill-slopes now practically bare. The only forest at present is a square mile of military 'reserved' forest, but large areas of waste, in which the people and Government are jointly interested, have been declared 'protected' forests. Of these the most important is that known as the Khwarra-Zira forest in the south-east corner of the District. Fruit gardens and orchards are numerous, especially near Peshāwar city.

The District contains quarries of slate and marble, and Mines and kankar is found in considerable quantities. Gold is washed minerals. in the Indus above Attock and in the Käbul river, but the yield is very small.

Peshāwar is noted for its turbans, woven either of silk or Arts and of cotton, with silk edges and fringes, and a great deal of cotton manufaccloth is produced. Cotton fabrics, adorned with coloured wax, and known as 'Afrīdi waxcloth,' are now turned out in large quantities for the European market. The principal woollen manufactures are felted mats and saddle-cloths, and blankets; glazed earthenware of considerable excellence is made, and a considerable manufacture of ornamental leather-work exists. Copper-ware is largely turned out. Matting, baskets, and fans are made of the dwarf-palm.

The main trade of the District passes through the city of Commerce Peshāwar, and though of varied and not uninteresting nature, is less extensive than might perhaps have been expected. In $1903-4$ the value of the trade as registered was 182.5 lakhs, of which 68 lakhs were imports. The bulk of Indian commerce with Northern Afghānistān and the countries beyond (of which Bokhāra is the most important), Dīr, Swāt, Chitrāl, Bājaur, and Buner, passes through Peshāwar. The independent tribes whose territories adjoin the District are also supplied from it with those commodities which they import. Besides Peshāwar city, there are bazars in which a certain amount of trade is done at Naushahra, Kalān, Hōti Mardān, Shankargarh, Tangi, Chārsadda (Prāng), and Rustam. The chief exports in 1903-4 were European and Indian cotton piece-goods, raw cotton, yarn, indigo, turmeric, wheat, leathern articles, manufactured articles of brass, copper, and iron, salt, spices, sugar, tea, tobacco, and silver.

The transactions of the Peshãwar market, however, are insignificant when compared with the stream of through traffic from the direction of Kābul and Bokhāra which passes on, without stopping at Peshāwar, into the Punjab and Northern India. 
Communi- The main line of the North-Western Railway enters the cations. District by the Attock bridge over the Indus, and has its terminus at Peshāwar, whence an extension runs to Fort Jamrūd. A branch line also runs from Naushahra through Mardān to Dargai. The District possesses 157 miles of metalled roads, of which 40 are Imperial military, $93 \mathrm{Im}$ perial civil, I 7 belong to the District board, and 7 to cantonments. There are 672 miles of unmetalled roads $(23$ Imperial military, 123 Imperial civil, and 516 District board). The grand trunk road runs parallel with the railway to Peshãwar and thence to Jamrūd at the mouth of the Khyber Pass, and a metalled road from Naushahra via Mardān crosses the border from the Malakand Pass into Swàt. Other important roads connect Peshāwar with Kohāt, with Abāzai, with Michni, with the Bārā fort, and with Cherāt. The Khyber Pass is the great highway of the trade with Kābul and Central Asia, and is guarded two days a week for the passage of caravans. The Indus, Swāt, and Kābul rivers are navigable at all seasons, but are not much used for traffic. The Indus is crossed by the Attock railway bridge, which has a subway for wheeled traffic, and by three ferries. There are four bridges of boats and six ferries on the Kābul river and its branches, two bridges of boats and six ferries on the Landai, and three bridges of boats and twelve ferries on the Swāt river and its branches.

District subdivisions and staff.

The District is divided for administrative purposes into five tahsïls, each under a tahsïldär and naib-tahsïldär, except Peshāwar, where there are a tahsildār and two naibs. The tahsīls of Mardān and Swābi form the Yūsufzai subdivision, in charge of an Assistant Commissioner whose head-quarters are at Mardān, the home of the famous Corps of Guides. This officer is entrusted, under the orders of the Deputy-Commissioner, with the political supervision of Buner and the Yũsufzai border. European officers with the powers of subdivisional officers are in charge of Peshāwar city, and of the Chārsadda and Naushahra tahsils. The Deputy-Commissioner is further assisted by an Assistant Commissioner, who is in command of the border military police. There are also three Extra Assistant Commissioners, one of whom has charge of the District treasury. The District Judge and the Assistant Commissioner at Mardān have the powers of Additional District Magistrates.

Civil jus. The Deputy-Commissioner as District Magistrate is respontice and crime. sible for the criminal work of the District ; civil judicial work is under a District Judge, and both are supervised by the 
Divisional and Sessions Judge of the Peshāwar Civil Division. The Assistant Commissioner, Mardān, has the powers of a Subordinate Judge, and in his civil capacity is under the District Judge, as also are two Munsifs, one at head-quarters and one at Mardān. There is one honorary Munsif at Peshāwar. The Cantonment Magistrate at Peshāwar is Small Cause Court Judge for petty civil cases within cantonment limits. The criminal work of the District is extremely heavy, serious crime being very common. The Frontier Crimes Regulation is in force, and many cases are referred to the decision of councils of elders. Civil litigation is not abnormally frequent. Important disputes between Pathān families of note are, when possible, settled out of court by councils of elders under the control of the Deputy-Commissioner. The commonest type of civil suit is based on the claim of reversionary heirs to annul alienations of lands made by widows and daughters of deceased sonless proprietors, as being contrary to custom.

The plain south of the Kābul river and the rich doāb Land between the Kābul and Swät rivers have always been under revenue the control of the central government of the time, while tration. the Khattak hills and the great plain north of the Swāt and Kābul rivers have generally been independent.

In 1834 the Sikhs finally gained a firm hold on the $d o \bar{a} b$ and the tract south of the Kābul. They imposed a full assessment and collected it through the leading men, to whom considerable grants were made. The Sikh collections averaged $6 \frac{1}{2}$ lakhs from 1836 to 1842 , compared with $5 \frac{2}{3}$ lakhs under the Durrānis. These figures exclude the revenues of Yüsufzai and Hashtnagar, which are also excluded from the first summary settlement, made in $1849-50$, when the demand was ro lakhs. Yūsufzai was settled summarily in 1847 and Hashtnagar in $185^{\circ}$.

In 1855 a new settlement was made for the whole District. It gave liberal reductions in Peshãwar, the $d o \bar{a} b$, Daudzai, and Naushahra, where the summary assessment, based on the Sikh demands, had been very high, while the revenue in Yuusufzai was enhanced. The net result was a demand of less than 8 lakhs. This assessment was treated as a summary one, and a regular settlement was carried out between 1869 and 1875 , raising the revenue to 8 lakhs. The settlement worked well, particularly in those villages where a considerable enhancement was made, the high assessment acting as a stimulus to increased effort on the part of the cultivators. The revenue, however, was recovered with the greatest difficulty; 
and the history of the settlement has been described as one continuous struggle on the part of the tahsildar to recover as much, and on the part of the landowners to pay as little, of the revenue demand as possible. This was due to the character and history of the people, and does not reflect at all on the pitch of the assessment. The latest revision began in 1892 and was finished in 1896 . The chief new factors in the situation were the opening of the Swät and the Kābul River Canals, the development of communications in 1882 by means of the railway, the rise in prices, and the increase in prosperity due to internal security. Assessed at half the net 'assets' the demand would have amounted to $23 \frac{3}{4}$ lakhs, or Rs. 2-7-7 per cultivated acre. The revenue actually imposed was slightly more than II lakhs, an increase of about $2 \frac{1}{3}$ lakhs, or 28 per cent. on the former demand. Of the total revenue Rs. $1,89,000$ is assigned, compared with Rs. I,76,000 at the regular settlement. The incidence per cultivated acre varies from Rs. I-I I-4 in Chãrsadda to R. o-8-8 in Mardãn.

Frontier remissions are a special feature of the revenue administration. A portion of the total assessment of a border estate is remitted, in consideration of the responsibility of the proprietors for the watch and ward of the border. The remissions are continued during the pleasure of Government on condition of service and good conduct.

The total collections of revenue and of land revenue alone are shown below, in thousands of rupees:-

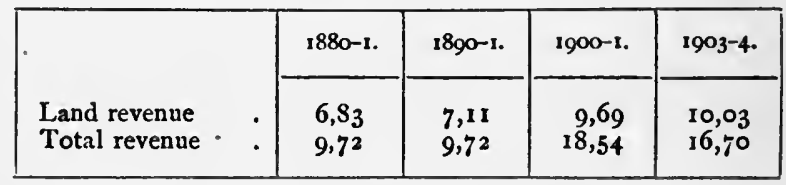

Local and Peshāwar is the only municipality. Outside this area local municipal. affairs are managed by a District board, whose income is mainly derived from a local rate. In $1903^{-4}$ the income of the board was Rs. I, I 5,000, and the expenditure Rs. I, 21,000 , public works forming the largest item.

Police and The regular police numbers 1,265 of all ranks, of whom jails. 2 Io are cantonment and 277 municipal police. There are twenty-seven police stations and twenty road-posts. The police force is under the control of a Superintendent, who is assisted by three European Assistant Superintendents ; one of these is in special charge of Peshãwar city, while another is stationed at Mardān. 
The border military police numbers 544 men, under a commandant who is directly subordinate to the DeputyCommissioner. They are entirely distinct from the regular police. The posts are placed at convenient distances along the frontier, and the duty of the men is to patrol and prevent raids, to go into the hills as spies and ascertain generally what is going forward. The system is not in force on the Yüsufzai border, as the tribes on that side give little or no trouble. The District jail at head-quarters can accommodate 500 prisoners.

Since $189 \mathrm{r}$ the population has actually gone back in literacy, Education. and in rgor only 4 per cent. (6.5 males and 0.1 female) could read and write. The reason is that indigenous institutions are decreasing in number every year owing to the lack of support, while public instruction at the hands of Government has failed as yet to become popular. The influence of the Mullās, though less powerful than it used to be, is still sufficient to prevent the attendance of their co-religionists at Government schools. The education of women has, however, made some progress. This is due in a large measure to the exertions of lady missionaries, who visit the zananas and teach the younger women to read Urdū, Persian, and even English. The number of pupils under instruction was 1,833 in $1880-1$, ro,655 in $1890-1,9,242$ in $1900-1$, and 10,036 in $1903-4$. In the latest year there were 1o secondary and 78 primary (public) schools, and $3 \circ$ advanced and 208 elementary (private) schools, with 64 girls in public and 755 in private institutions. Peshāwar city contains an unaided Arts college and four high schools. The total expenditure on education in 1903-4 was Rs. 61,000, to which District funds contributed Rs. 25,000, the Peshāwar municipality Rs. 6,400, and fees Rs. I4,700.

Besides the Egerton Civil Hospital and four dispensaries in Hospitals Peshāwar city, the District has five outlying dispensaries. In and disthese institutions there are 133 beds for in-patients. In 1904 the number of cases treated was 202,793 , including 2,980 in-patients, and 9,290 operations were performed. The income amounted to Rs. 27,600, which was contributed by municipal funds and by the District board equally. The Church Missionary Society maintains a Zanāna Hospital, named after the Duchess of Connaught, which is in charge of a qualified European lady.

The number of successful vaccinations in $1903-4$ was 24,000 , Vaccinarepresenting 33 per 1,000 of the population. tion.

[J. G. Lorimer, District Gazetteer (1897-8).] 
Peshāwar Tahsīl.-Head-quarters tahsil of Peshāwar District, North-West Frontier Province, lying between $33^{\circ} 43^{\prime}$ and $34^{\circ} \times 3^{\prime} \mathrm{N}$. and $71^{\circ} 22^{\prime}$ and $71^{\circ} 45^{\prime} \mathrm{E}$., with an area of $45^{1}$ square miles. The population was 248,060 in $190 \mathrm{r}$, and 226, I I 3 in 1891 . The tahsil consists of two distinct tracts, the first of which is a low-lying riverain basin, through which flow the branches of the Kābul river north of Peshāwar city. This tract comprises the old Daudzai tappa, which is lowlying and swampy, and that of Khālsa, which also contains a good deal of marshy ground, especially near Dilazāk and Muhammadzai. The second tract consists of uplands which rise gradually to the Afridi hills. It comprises the Khalil and Mohmand tappas, so named from the Pathān tribes which hold them. The tahsil is intersected by the KĀBUL River Canal. It contains the city and cantonment of Peshäwar $(95,147)$, its head-quarters, and 259 villages. The land revenue and cesses amounted in $1903-4$ to a little more than Rs. 5,00,000.

Chārsadda Tahsīl. - North-western tahsīl of Peshāwar District, North-West Frontier Province, lying between $34^{\circ} \mathbf{2}^{\prime}$ and $34^{\circ} 32^{\prime} \mathrm{N}$. and $7 \mathrm{r}^{\circ} 30^{\prime}$ and $7 \mathrm{r}^{\circ} 5^{6^{\prime}} \mathrm{E}$., with an area of 380 square miles. The population was $\mathrm{r}_{42,75^{6}}$ in $\mathrm{r} 90 \mathrm{r}$, and r,32,917 in r891. It contains three towns, CHĀRSADDA and PRĀNG $(19,354)$, the head-quarters, and TANG1, $(9,095)$ with r68 villages. The land revenue and cesses amounted in r $903-4$ to Rs. 3,60,000. The tahsil consists of the $d o \bar{a} b$ and Hashtnagar tappas or circles. The former lies between the Adizai branch of the $K \bar{a}$ bul river and the Swāt, and is fertile, highly cultivated, with numerous villages, and better wooded than other parts of the District; even the uplands which run along the foot of the Mohmand hills for their whole length are now irrigated by private canals. It is mainly held by the Gigiāni clan and by Mohmands. The Hashtnagar tappa comprises a strip of plain country with a rich clay soil, which stretches ro miles eastward of the Swāt, and from the Utmān Khel hills on the north to the Kābul river on the south. It is held by Muhammadzai Pathāns, and in it lies Chārsadda, the head-quarters of the tahsil. This tappa is intersected by the Swāt River Canal.

Yūsufzai.-The term Yūsufzai, properly speaking, includes the whole territory held by the Yüsufzai tribe of Pathāns in the North-West Frontier Province, which extends beyond Peshāwar District into the Political Agency of Dīr, Swāt, and Chitrāl, and includes the valleys of Panjkora, Dīe, BASHKar, 
SWĀT and Buner. According to the Pathāns themselves, however, Yuusufzai applies only to Dïr, Swāt, and Buner, including the Chamla valley. Yussufzai is the name adopted for a subdivision in Peshāwar District which comprises the two tahsils of Mardān and Swãbi. In the north of the subdivision are three main valleys and minor glens almost surrounded by rugged hills. South of these lies a large plain separating them from the low ridge called the Sar-i-Maira, which slopes towards the centre and drains into the Kalpanni and the valley of the Indus to the east of that ridge. It consists of the six tappas or minor divisions of Baezai, Kamālzai, Amāzai, Razzar, Utmān, and Bolak. The Baezai tappa formed the battle-ground between the descendants of Yüsuf and Mandan. The Utmān Khel and Khattak tribe were called in on both sides as mercenaries, and ended by taking possession of the greater part of the Baezai valley themselves. The celebrated Takht-i-Bhai ruins are in this tappa. The chief village is Landkhwar. Communication with Swāt is kept up through the Mora Shākot and Malakand passes. The villages of Mardãn and Hoti are in the Kamālzai tappa. The Amãzai tappa is surrounded on three sides by hills; it is often called the Sadhum valley, and is watered by the Makām river. The chief village is Rustam, at which there is a police station. The people of the Razzar tappa are all descendants of Mandan. It contains several large villages, and a police station at Kalu Khān. The chief village of Utmān is Swābi, which contains a tahsīli and police station. The Bolak tappa is entirely Khattak, and does not properly belong to Yūsufzai at all, having been joined to the Swābi tahsīl for administrative reasons. Besides the Makām river, the subdivision is watered by another considerable stream, the Kalpāni, which takes its rise in the Mora pass, flows past Mardān and Hoti, is afterwards joined by the Makām, and finally falls into the Kābul river opposite Naushahra cantonment. The soil consists of a fine alluvial deposit, covered in large part with luxuriant verdure. The Swät River Canal, opened in 1885 , affords ample irrigation to the greater part of the Mardann tahsil, and there is a certain amount of irrigation from wells.

Mardān Tahsīl. - Tahsīl of Peshāwar District, North-West Frontier Province, lying between $34^{\circ} 5^{\prime}$ and $34^{\circ} 32^{\prime} \mathrm{N}$. and $71^{\circ} 49^{\prime}$ and $72^{\circ} 24^{\prime} \mathrm{E}$., in the centre of the part of the District which lies north of the Kābul river, with an area of 6 ro square miles. It comprises the greater portion of the Yüsufzai plain, and with the Swäbi tahsïl forms the YūsurzaI subdivision of 
Peshāwar District. The population in 1901 was 137,215 , compared with 113,877 in 1891 . It contains the cantonment of MARDĀN $\left(3,57^{2}\right)$ and 130 villages, including Hoti and Rustam. The land revenue and cesses amounted in $1903-4$ to Rs. $x, 76,000$.

Swābi Tahsil.-Easternmost tahsīl of Peshāwar District, North-West Frontier Province, lying between $33^{\circ} 54^{\prime}$ and $34^{\circ} 22^{\prime} \mathrm{N}$. and $72^{\circ} 12^{\prime}$ and $72^{\circ} 45^{\prime}$ E., with an area of 467 square miles. It forms, with the Mardān tahsīl, the Yūsufzai subdivision. It consists of a level plain intersected by two considerable streams, the Naranji Khwar and Badri, and many smaller ravines. The population in 1901 was 144,513 , compared with 130,687 in 1891 . It contains 94 villages, including Swäbi, the head-quarters. The land revenue and cesses amounted in $1903-4$ to Rs. 3,00,000. The principal tract in the tahsil is the Razzar, occupying its north-eastern half, which is so called after the branch of the Mandanr Pathāns which holds it. The central portion is held by the Sadozai and the eastern extremity by the Utmanzai, both branches of the Mandanr. The tahsil was formerly known as Utmān Bulak.

Naushahra Tahsī1.-Tahsil of Peshāwar District, NorthWest Frontier Province, lying between $33^{\circ} 47^{\prime}$ and $34^{\circ} 9^{\prime} \mathrm{N}$. and $71^{\circ} 40^{\prime}$ and $72^{\circ} 15^{\prime} \mathrm{E}$., with an area of 703 square miles. It consists of a small tract of low-lying riverain land on both sides of the Kābul river, known as the Khālsa tappa, and of the Khattak pargana which includes the Khwarra-Nīāb valley and is separated from it by the Khattak range. This range culminates in the Ghaibanna Sir $(5,136$ feet in height) on the western boundary of the tahsil, and the sanitarium of Cherāt $(4,542$ feet), whence the range trends to the eastward, gradually sinking to 2,380 feet at Hodi Sir above the Indus. Half the tahsil is hilly and very broken country, the main part of its area consisting of the arid and barren slopes on the north of the Khattak hills towards Käbul. The north-west corner is irrigated by the $\mathrm{K} \bar{A}$ BUL RIver Canal. The population in rgor was 116,163 , compared with 180,201 in 1891 . It contains the town of NaUshaHra $(9,5 \mathrm{r} 8)$, the head-quarters, the hill station of CHERĀT, and 142 villages. The land revenue and cesses amounted in 1903-4 to Rs. $1,21,000$.

Abāzai.-Fort and village in the Chārsadda tahsīl of Peshāwar District, North-West Frontier Province, 24 miles north of Peshāwar city, on the left bank of the Swāt river, and a mile from its exit from the hills. The river, here 150 yards wide, is crossed by a ferry, and is the highest point in British ter- 
ritory where a ferry is stationed. The fort, which lies between Abãzai village and the hills, was constructed in $r 85^{2}$, and has been very effective in preventing raids by the Utmān Khel and Mohmands on British territory. It was made over to the border military police in 1894 , and is held by 30 men of this force. Its chief interest now consists in the fact that it is close to the head-works of the Swät River Canal.

Chărsadda Town.-Head-quarters of the tahsil of the same name in Peshāwar District, North-West Frontier Province, situated in $34^{\circ} 9^{\prime} \mathrm{N}$. and $71^{\circ} 45^{\prime} \mathrm{E}$., on the left bank of the Swāt river, 16 miles north-east of Peshāwar city. Population (r9or), including Prāng, 19,354. A good metalled road connects the town with Nahakki on the road from Peshāwar to Abāzai. By this route the distance to Peshāwar is 20 miles, and the road crosses five permanent bridges of boats. Chārsadda is a large and prosperous town, with a considerable trade, chiefly in agricultural produce, in the hands of enterprising Hindus, but Muhammadan agriculturists form the majority of the population. It has a dispensary and a vernacular middle school maintained by the District board.

Chārsadda is contiguous to the town of Prāng; and these two places were identified by General Cunningham with the ancient Pushkalāvati, capital of the region at the time of Alexander's invasion, and transliterated as Peukelaus or Peukelaotis by the Greek historians. Its chieftain (Astes), according to Arrian, was killed in defence of one of his strongholds after a prolonged siege by Hephaistion. Ptolemy fixes its site upon the eastern bank of the Suastene or Swāt. In the seventh century A.D. Hiuen Tsiang visited the city, which he describes as being roo li (16 $\frac{2}{3}$ miles) north-east of Peshāwar. A stüpa, erected over the spot where Buddha made an alms-offering of his eyes, formed the great attraction for the Buddhist pilgrim and his co-religionists. The city, however, had even then been abandoned as a political capital in favour of Purushapura, Parashāwara, or Peshāwar. It probably extended over a large area, and the entire neighbourhood is covered with vast ruins. Excavation was carried out in the neighbourhood of Chārsadda for about two months in the spring of $1902-3$. Some interesting finds of coins and pottery ornaments, including an engraved amethyst, were made, and the remains of the ancient Bāla Hisār (Akropolis) were mapped.

Cherāt.-Hill sanitarium and cantonment in the Naushahra tahsil of Peshāwar District, North-West Frontier Province, situated in $33^{\circ} 50^{\prime} \mathrm{N}$. and $71^{\circ} 54^{\prime} \mathrm{E}$, , on the west of the 
Khattak range, 30 miles south-east of Peshāwar. Cherãt, which is 4,500 feet above sea-level, was first used as a sanitarium for troops in $186 \mathrm{I}$, and was declared a cantonment in 1886 . $A$ hospital, a church, and a few bungalows have been built. The station has a good water-supply, and is throughout the summer the head-quarters of the Peshāwar division command, and of one of the two British regiments stationed at Peshāwar. A detachment of the other British regiment is also sent here. The mean temperature in June is $82^{\circ}$ at Cherāt, compared with $90^{\circ}$ at Peshāwar, and the nights are bearable. The hill commands a view of the whole of the Peshāwar valley on one side, and on the other of a portion of the Khwarra valley in Peshāwar District, and of Kohāt District as far as the Indus. The population, according to the Census of March, rgor, was only 376 (no Europeans), but in the hot season the garrison sometimes numbers $\mathrm{I}, 000$ men.

Hashtnagar ('Eight cities').- Tract in the Chârsadda tahsil of Peshāwar District, North-West Frontier Province, comprising a strip of country that extends ro miles eastward from the Swāt river, and stretches from the hills on the north to the Kābul river on the south, between $34^{\circ} 3^{\prime}$ and $34^{\circ} 25^{\prime} \mathrm{N}$. and $71^{\circ} 37^{\prime}$ and $71^{\circ} 57^{\prime} \mathrm{E}$. It is said to derive its name from its eight chief villages, which probably occupy the site of the ancient Peukelaotis or Pushkalāvati. General Cunningham, however, believed the modern term to be a corruption of Hastinagara, the city of Hasti, the Astes of Arrian. Raverty gave the old name as Ashnagar, but he does not explain its derivation. Before the Yūsufzai Afghanns settled in the Peshāwar valley, Hashtnagar was held by the Shalmānis, a Tājik race, subjects of the Sultān of Swāt, and the Hisār of Hashtnagar was the capital of a province which extended to the Kalpāni. After Bābar's time it became the stronghold of a Muhammadzai chieftain. The inhabitants are Muhammadzai Pathāns. The area is 303 square miles, and the tract is naturally divided into two sections : the sholgira, or lowlands, irrigated from the Swāt river ; and the maira, or high plain, which is intersected by the Swāt River Canal. Near the head of the canal is ABĀZAI Fort.

Mackeson, Fort.-Formerly an important frontier fort in Peshāwar District, North-West Frontier Province, built to command the north entrance to the Kohāt Pass, from which it is $3 \frac{1}{2}$ miles distant. It consisted of a pentagon, an inner keep, and a horn-work, with accommodation for 500 troops; but with the exception of the keep it was dismantled in 1887 , and is now held by 29 men of the border military police. 
Mardān Town.-Cantonment in Peshāwar District, NorthWest Frontier Province, and permanent head-quarters of the Queen's Own Corps of Guides. It is also the head-quarters of the Mardān tahsil and the Yūsufzai subdivision. Population (1901), 3,572. The cantonment is situated in $34^{\circ} 12^{\prime} \mathrm{N}$. and $72^{\circ} 2^{\prime} \mathrm{E}$., on the right bank of the Kalpāni river, 33 miles north-east of Peshāwar and 15 miles north of Naushahra, on the North-Western Railway. The fort was built by Hodson of the Guides in 1854 . The civil lines lie in the southern part of the cantonment on the Naushahra road, and contain the Assistant Commissioner's bungalow, courthouse, tahsili, Government dispensary, and other public offices. An Anglo-vernacular middle school is maintained by the District board. The village of Hoti, from which the station is sometimes called Hoti Mardān, lies 2 miles from the cantonment.

Michni.-Fort in the District and tahsīl of Peshāwar, NorthWest Frontier Province, situated in $34^{\circ} \mathrm{II}^{\prime} \mathrm{N}$. and $7 \mathrm{r}^{\circ} 27^{\prime} \mathrm{E}$., on the left bank of the Käbul river, close to where it issues from the hills, and 15 miles north of Peshāwar city. The fort, which commands an important ferry over the Käbul river, was constructed in $185 \mathrm{I}-2$ on account of the numerous raids by Mohmands from beyond the frontier. Lieutenant Boulnois, in command of the party constructing the fort, was murdered here by Mohmands in $185^{2}$; and in 1873 Major MacDonald, the commandant of the post, was murdered in its vicinity. There is no village of Michni, but the Tarakzai Mohmands have settlements all round, those on the south side of the river being in British territory. Fort Michni was formerly under the command of a field officer, subordinate to the Brigadier-General at Peshāwar; but in 1885 it was handed over to the border military police, who now hold it with a garrison of twenty men.

Naushahra Town.-Town and cantonment in Peshāwar District, North-West Frontier Province, and head-quarters of the tahsil and subdivision of the same name, situated in $34^{\circ} \mathrm{N}$. and $72^{\circ} \mathrm{E}$., on the North-Western Railway and the grand trunk road, 27 miles due east of Peshāwar. Population (Igor), 9,518. The cantonment stretches along the right bank of the Kābul river on a sandy plain, 3 miles in diameter, and is surrounded by low hills on all sides except the north, which is open towards the river. The garrison now consists of one British infantry regiment, two native cavalry and four infantry regiments, a mountain battery, and a bearer corps, belonging 
to the Peshãwar division of the Northern Command. The Kabul river is crossed by a permanent bridge of boats, whence roads lead to Mardān and Chārsadda. The iron road and railway bridge across the river was opened on December $\mathbf{r}$; 1903. The village of Naushahra Khurd, west of the cantonment, and the large village of Naushahra Kalān, on the north bank of the Kābul, are both outside cantonment limits. The head-quarters of the Naushahra tahsil, with the police station, are in the former, 3 miles from the cantonment. The town contains a Government dispensary and a vernacular middle school, maintained by the District board.

Peshāwar City.-Capital of the North-West Frontier Province, and head-quarters of the District and tahsil of the same name, situated in $34^{\circ} \mathrm{I}^{\prime} \mathrm{N}$. and $7 \mathrm{I}^{\circ} 35^{\prime} \mathrm{E}$. The cantonment is situated on a ridge overlooking the surrounding plain and the city, which lies near the left bank of the Bārā stream, I $3 \frac{1}{2}$ miles south-east of the junction of the Swāt and Kābul rivers, and $10 \frac{1}{2}$ miles from Jamrūd fort near the entrance of the Khyber Pass. It is distant by rail from Calcutta $1,55^{2}$ miles, and from Bombay 1,579 miles, and by road from Kābul 190 miles. It is the terminus of the grand trunk road, but a branch of the North-Western Railway runs on to Jamrūd. The population was 79,982 in $1881,54,191$ in $189 \pi$, and 95,147 in I 901 , consisting of $68,35^{2}$ Muhammadans, $18,55^{2}$ Hindus, 5,144 Sikhs, and 3,063 Christians. Of the total population, $2 \mathrm{I}, 804$ live in cantonments.

Peshāwar was in the time of Fa Hian the capital of the Gandhāra Province, and is historically important at all later periods. (See Peshāwar District.) It was famous during the early centuries of the Christian era as containing the begging-pot of the Buddha, a holy pipal tree whose branches are said to have given shade to the Master, and an enormous stüpa built by Kanishka. Buddhist remains still mark its early greatness. The name is not improbably derived from Parashãwara or Purushapura, the seat of a king named Purush ; and the present form Peshāwar is referred to the emperor Akbar, whose fondness for innovation is said to have led him to change the name, of whose meaning he was ignorant, to Peshāwar, the 'frontier town.' In $155^{2}$ Humāyūn found the fortress in ruins, but had it repaired and entrusted it to a governor, who successfully defended it against the Afghāns under Khān Kajū. The town appears to have been refounded by Balgram, a contemporary of Akbar, and was much enlarged by General Avitabile, its governor under the Sikhs. It became the head-quarters of 
a District in 1849 , and the capital of the North-West Frontier Province in 1901 .

The modern city has but slight architectural pretensions, the houses, though lofty, being chiefly built of small bricks or mud, held together by a wooden framework. It is surrounded by a mud wall, built by General Avitabile, which is gradually being replaced by a wall of brick. The city has sixteen gates. The main street, known as the kissa kahani, which is entered from the Kābul gate (re-erected as a memorial to Sir Herbert Edwardes), is a broad roadway 50 feet in width, consisting of two double rows of shops, the upper rooms of which are generally let out as lodgings; the street is well paved, and at busy times presents a very picturesque sight. The remainder of the city proper consists of squares and markets, with narrow and irregular streets and lanes. A masonry canal runs through the centre of the city, which is, however, only used to carry off drain-water and sewage. Drinking-water is brought down in pipes from the water-works, for which the municipal committee pays a yearly rental. Wells are used only in the hot season to supply colder water than the pipes afford. The sanitary and conservancy arrangements are very good, and all the drains are paved. There are now very few old houses of architectural importance, most of them having been destroyed at the time of the capture of the city by the Sikhs from the Durrānis. Several handsome mosques ornament the city; and a large building, known as the Gor Khattri, once a Buddhist monastery, and subsequently formed into a Hindu temple, is now used as the tahsili. Just without the wall, on the north-western side, a quadrilateral fort, the Bāla Hisār, crowns a small eminence completely dominating the city. Its walls of sun-dried brick rise to a height of 92 feet above the ground, with a fausse-braye of 30 feet; bastions stand at each corner and on three of the faces, while an armament of guns and mortars is mounted above.

South-west of the city, stretching from just outside the walls, are the suburbs of Bhāna Māri and Deri Bāghbānān, where there are gardens noted for their fruit, producing quinces, pomegranates, plums, limes, peaches, and apples in abundance. These gardens, especially a public garden called the Wazir Bāgh, form a favourite pleasure-ground of the people; north of the city is another public pleasure-ground, the Shāhi Bāgh or 'royal garden.'

Two miles west of the city lie the cantonments, where the civil offices are also situated. The cantonments were occupied by British troops soon after annexation in $1848-9$. The gar- 
rison has been much reduced and consists at present of one battery of field artillery, two regiments of British and three of native infantry, one regiment of native cavalry, and one company each of sappers and miners, bearer corps, and army hospital native corps. The garrison forms part of the Peshāwar military division of the Northern Command, and the head-quarters of the division are situated here.

The municipality was constituted in 1867 . The income and expenditure during the ten years ending $1902-3$ averaged 2.3 and 2.15 lakhs respectively. In $1903-4$ the income was 2.8 lakhs, of which more than 2 lakhs were derived from octroi, while the expenditure amounted to 2.9 lakhs, the chief heads of charge being conservancy (Rs. 26,000), education (Rs. 1 2,000), hospitals and dispensaries (Rs. 18,000 ), public safety (Rs. 46,000), and administration (Rs. 36,000). The income and expenditure of cantonment funds during the ten years ending 1902-3 averaged Rs. 53,000 and Rs. 52,500 respectively; in $1903-4$ the income was Rs. 69,000 , and the expenditure Rs. 70,000 .

The main trade of the District passes through the city of Peshāwar. Though of a varied and not uninteresting nature, it is less extensive than might perhaps have been expected, but its position makes it important as an entrepott for Central Asia. The principal foreign markets having dealings with Peshāwar are Kābul and Bokhāra. From the former place are imported raw silk, worsted, cochineal, jalap, asafoetida, saffron, resin, simples, and fruits, both fresh and dried, principally for reexportation to the Punjab and Hindustān, whence are received in return English piece-goods, cambrics, silk, indigo, sugar, tea, salt, and spices. Bokhāra supplies gold coins, gold and silver thread and lace, principally for re-exportation to Kashmir, whence the return trade is shawls. Iron from Bājaur, skins, fibres and mats made of the dwarf-palm (mazri), are the only remaining items of importance coming from beyond the border.

The city possesses an unaided Arts college attached to the Mission high school, and four high schools : namely, the municipal and Edwardes Mission Anglo-vernacular high schools, and two unaided Anglo-vernacular high schools. It also contains a civil hospital and four dispensaries. Another institution is the Martin Lecture Hall and institute, with its reading-room and library, also maintained by the Peshãwar Mission.

Prāng.-Town in the Chārsadda tahsil of Peshāwar District, North-West Frontier Province, situated in $34^{\circ} 8^{\prime} \mathrm{N}$. and 
$7 \mathrm{I}^{\circ} 49^{\prime}$ E., above the junction of the Swāt and Kābul rivers, 16 miles north-east of Peshãwar. It is practically a portion of the town of CHĀRSADDA. The population, apart from Chārsadda, in I 901 was 10,235, consisting chiefly of Muhammadzai Pathāns.

Shabkadar.-Fort in the Chārsadda tahsīl of Peshāwar District, North-West Frontier Province, situated in $34^{\circ} 13^{\prime} \mathrm{N}$. and $71^{\circ} 34^{\prime}$ E., 17 miles north-west of Peshāwar city, with which it is connected by a good road leading to Abāzai across three branches of the Kābul river. Originally built by the Sikhs, and by them called Shankargarh, the fort lies 2 miles from the village of Shabkadar; but a town has now sprung up round it, which is a local centre of trade with the adjoining Mohmand hills, and which in r 1901 had a population of 2,373. The fort is a strong one, and used to be garrisoned by regular troops; but in 1885 it was nuade over to the border military police, who now hold it with 28 men. In August, 1897 , it was suddenly attacked by a force of Mohmands, who succeeded in plundering the town and burning the Hindu shops and houses, but the small police garrison was able to hold the fort itself. On August 9 the Mohmands were defeated with loss by a small force under General Elles, an engagement signalized by a brilliant charge of two squadrons of the $13^{\text {th }}$ Duke of Connaught's Lancers.

Tangi.-Town in the Chārsadda tahsīl of Peshãwar District, North-West Frontier Province, situated in $34^{\circ} 17^{\prime} \mathrm{N}$. and $71^{\circ} 42^{\prime}$ E., 29 miles north of Peshāwar city. Population (1901), 9,095. The Swāt river runs west of the town, and the Swāt River Canal, with the famous Jhindi aqueduct, is about 3 miles off. The inhabitants are Muhammadzai Pathāns. Faction is rife, and the place owes its importance to its proximity to the independent tribe of Utman Khel, against whom it has always held its own.

Kohāt District.-Central District of the North-West BounFrontier Province, lying between $32^{\circ} 48^{\prime}$ and $33^{\circ} 45^{\prime} \mathrm{N}$. and daries, con$70^{\circ} 30^{\prime}$ and $72^{\circ} \mathrm{I}^{\prime}$ E., with an area of 2,973 square miles. figuratio The District has the shape of an irregular rhomboid, with one and river arm stretching north-east towards the Khwarra-Zira forest in systems. Peshāwar District. It is bounded on the north by Peshāwar District, and by the hills inhabited by the Jowāki and Pass Afrīdis; on the north-west by Orakzai Tīrāh ; on the southwest by Kâbul Khel territory (Wazīristān); on the south-east by Bannu and the Miānwāli District of the Punjab; and on the east by the Indus. Its greatest length is ro4 miles, and its greatest width 50 miles. 
The District consists of a succession of ranges of broken hills, whose general trend is east and west, and between which lie open valleys, seldom more than 4 or 5 miles in width. These ranges are of no great height, though several peaks attain an altitude of 4,700 or 4,900 feet. As the District is generally elevated, Hangu to the northward being 2,800 feet and Kohāt, its head-quarters, I,700 feet above sea-level, the ranges rise to only inconsiderable heights above the plain. The general slope is to the east, towards the Indus, but on the south-west the fall is towards the west into the Kurram river. The principal streams are the Kohãt and Teri Tois ('streams'), both tributaries of the Indus, and the Shkalai which flows into the Kurram. The Kohāt Toi rises in the Māmozai hills. It has but a small perennial flow, which disappears before it reaches the town of Kohāt, but the stream reappears some miles lower down and thence flows continuously to the Indus. The Teri Toi has little or no perennial flow, and the Shkalai is also small, though perennial. The most fertile part is the Hangu tahsil, which comprises the valley of Lower and Upper Mirannzai. The rest of the District consists of ranges of hills much broken into spurs, ravines, and valleys, which are sometimes cultivated, but more often bare and sandy.

Geology. The rocks of the District belong chiefly to the Tertiary system, and consist of a series of Upper and Middle Tertiary sandstones with inliers of Nummulitic limestone. The limestones occur chiefly in the north, while sandstone is more prominent to the south. Below the Nummulitic beds is found the most important mineral of the District, namely, salt. It occurs, with bands of gypsum and red clay, below the eocene rocks at various localities, but is found in greatest quantity at Bahādur Khcl, where rock-salt is seen for a distance of about 8 miles and the thickness exposed exceeds $\mathrm{r}, 000$ feet. The salt is very pure, and differs remarkably in colour from that of the SALT RANGE, being usually grey, while that of the latter area is red or pink. There is no definite evidence as to its age, which is usually regarded as Lower Tertiary; but the underlying rocks are not exposed, and it has been classed with the overlying eocene on account of the apparent absence of any unconformity ${ }^{1}$.

Botany. The vegetation is composed chiefly of scrub jungle, with a secondary element of trees and shrubs. The more common plants are: Flacourtia sapida, $F$. sepiaria, several species of

1 Wynne: 'Trans-Indus Salt Region in the Kohāt District.' Memoirs, Geological Survey of India, vol. xi, part ii. 
Grewia, Zizyphus nummularia, Acacia Jacquemontii, A. leucophloea, Alhagi camelorum, Crotalaria Burhia, Prosopis spicigera, several species of Tamarix, Nerium odonum, Rhazya stricta, Calotropis procera, Periploca aphylla, Tecoma undulata, Lycium europaeum, Withania coagulans, W. somnifera, Nannorhops Ritchieana, Fagonia, Tribulus, Peganum Harmala, Calligonum polygonoides, Polygonum aviculare, P. plebejum, Rumex vesicarius, Chrozophora plicata, and species of Aristida, Anthistiria, Cenchrus, and Pennisetum.

Game of all kinds is scarce; leopards are occasionally shot Fanna. in the hills, and twenty years ago were quite common. There are practically no deer. Bears occasionally come down from the Sāmāna Range to Mīrānzai when the corn is ripe. Chikor and partridges abound in Mĩrānzai and the Teri tahsīl, and fish are abundant in the Kurram and the Indus.

The District as a whole lies high, and the hot season, though Climate oppressive, is short, and the spring and autumn months are and templeasant. The winter is very cold, and a cutting west wind, known as the 'Hangu breeze,' blows down the Mirānzai valley to Kohāt for weeks together. Owing to the great extremes of heat and cold pneumonia is common, but malarial fever is the chief cause of mortality.

The monsoon rains do not usually penetrate as far as Kohāt, and the rainfall is very capricious. The average fall at Kohāt is 18 inches, while the greatest fall since 1882 was 48 inches at Fort Lockhart on the Sāmanna in I900-I, and the least 5 inches at Kohāt in $\mathbf{1} 89 \mathbf{I}-2$. The distribution of the rain is equally uncertain; villages within the distance of a few miles suffering, some from drought and some from floods, at the same time.

The first historical mention of the District occurs in the History. memoirs of the emperor Bābar. The District was then, as now, divided between the Bangash and Khattak branches of the Pathān race, the Bangash occupying the Mĩrannzai valley, with the western portion of Kohāt proper, while the Khattaks held the remainder of the eastern territory up to the bank of the Indus. According to tradition the Bangash were driven from Gardez in the Ghilzai country, and settled in the Kurram valley about the fourteenth century. Thence they spread eastward, over the Mirānzai and Kohāt region, fighting for the ground inch by inch with the Orakzai, whom they cooped up at last in the frontier hills. The Khattaks are said to have left their native home in the Sulaiman mountains about the thirteenth century and settled in Bannu. Owing to a quarrel with 
the ancestors of the Bannūchis, they migrated northward two hundred years later and occupied their present domains.

Bābar made a raid through the District in 1505 , being attracted by a false hope of plunder, and sacked Kohăt and Hangu. The Mughal emperors were unable to maintain more than a nominal control over the tract. One of the Khattak chiefs, Malik Akor, agreed with Akbar to protect the country south of the Käbul river from depredations, and received in return a grant of territory with the right of levying tolls at the Akora ferry. He was thus enabled to assume the chieftainship of his tribe, and to hand down his authority to his descendants, who ruled at Akora, among them being the warrior poet Khushhāl Khãn.

Kohāt became part of the Durrāni empire in 1747 , but authority was exercised only through the Bangash and Khattak chiefs. Early in the nineteenth century, Kohāt and Hangu formed a governorship under Sardār Samad Khān, one of the Bārakzai brotherhood, whose leader, Dost Muhammad, usurped the throne of Afghānistān. The sons of Sardār Samad Khān were driven out about 1828 by the Peshāwar Sardārs, the principal of whom was Sultān Muhammad Khān. In the Teri tahsill, shortly after the establishment of the power of Ahmad Shāh Durrāni, it became the custom for a junior member of the Akora family to rule as sub-chief at Teri. This office gradually became hereditary, and sub-chiefs ruled the western Khattaks in complete independence of Akora. The history of affairs becomes very confused; the Akora chiefs were constantly interfering in Teri affairs; there were generally two or more rival claimants; the chiefship was constantly changing hands, and assassinations and rebellion were matters of everyday occurrence.

The Sikhs, on occupying the country, found themselves unable to levy revenue from the mountaineers. Ranjīt Singh placed Sultān Muhammad Khān in a position of importance at Peshāwar, and made him a grant of Kohāt, Hangu, and Teri. One Rasūl Khān became chief of Teri, and on his death in 1843 was succeeded by his adopted son, Khwāja Muhammad Khān. Meanwhile, Sultān Muhanmad Khān continued to govern the rest of the District through his sons, though the country was generally in a disturbed state, and the upper Mīrānzai villages were practically independent. When the Sikh troops took up arms at Peshāwar on the outbreak of the second Sikh War, George Lawrence, the British officer there, took refuge at Kohāt; but Sultān Muhammad Khān 
played him false, and delivered him over as a prisoner to the Sikhs. At the close of the campaign, Sultān Muhammad Khān and his adherents retired to Kābul, and the District with the rest of the Punjab was annexed to the British dominions. Khwāja Muhammad Khān had taken the British side and continued to manage the tahsill, which was made a perpetual jägir. In 1872 Khwāja Muhammad obtained the title of Nawāb and was made a K.C.S.I. He died in 1889 and was succeeded by his son, Khān Bahādur Abdul Ghafūr Khān.

At annexation the western boundary was left undefined; but in August, I85I, Upper Mīrānzai was formally annexed by proclamation, and an expedition was immediately dispatched up the valley to establish our rule. There was no fighting, beyond a little skirmishing with the Wazìrs near Biland Khel. The lawless Mĩranzai tribes, however, had no desire to be under either British or Afghān rule. They were most insubordinate, paid no revenue and obeyed no orders, while incursions from across the frontier continued to disturb the peace of the new District. At last, in 1855 , a force of 4,000 men marched into the valley, enforced the revenue settlement, and punished a recusant village at the foot of the Zaimukht hills. The people of Mirrānzai quickly reconciled themselves to British rule; and during the Mutiny of 1857 , no disturbance of any sort took place in the valley, or in any other part of the District. In March, 1858 , it was finally decided that the Kurram river was to form the western boundary of the District, thus excluding the Biland Khel on the opposite bank.

The construction of the road from Kohāt to Peshāwar was undertaken immediately after annexation, and at once brought the British into conflict with the border tribes, while the construction of the road to Bannu by Bahādur Khel was also the occasion of outbreaks in which the salt mines were seized by the insurgents.

Kohāt District contains one town and 298 villages. The The population at the last three enumerations was : (1881) I 74,762, people. (189r) 195, I48, and (1901) 217,865. It increased by $11 \cdot 5$ per cent. during the last decade, the increase being greatest in the Kohāt tahsil and least in Teri. The increase, though partly due to the presence of coolies, \&c., employed in making the Khushālgarh-Kohāt Railway, was mainly the result of increased tranquillity on the border. The District is divided into three tahsils, the chief statistics of which, in 1901, are shown on the next page. 


\begin{tabular}{|c|c|c|c|c|c|c|c|c|}
\hline \multirow{2}{*}{\multicolumn{2}{|c|}{ Tahsil. }} & \multirow{2}{*}{ 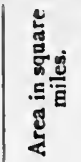 } & \multicolumn{2}{|c|}{ Number of } & \multirow{2}{*}{ 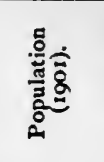 } & \multirow{2}{*}{ 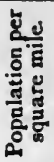 } & \multirow{2}{*}{ 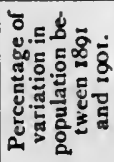 } & \multirow{2}{*}{ 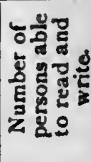 } \\
\hline & & & $\stackrel{\dot{\theta}}{\circ}$ & 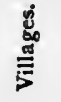 & & & & \\
\hline \multirow[t]{2}{*}{$\begin{array}{l}\text { Kobāt } \\
\text { Teri . } \\
\text { Hangu }\end{array}$} & & $\begin{array}{r}811 \\
1,616 \\
546\end{array}$ & $\begin{array}{c}\mathbf{1} \\
\cdots \\
\ldots\end{array}$ & $\begin{array}{r}89 \\
166 \\
43\end{array}$ & & $\begin{array}{r}114 \\
62 \\
87\end{array}$ & $\begin{array}{l}+13.7 \\
+10.4 \\
+10.6\end{array}$ & $\begin{array}{l}2,221 \\
1,629\end{array}$ \\
\hline & & 2,973 & $\mathbf{I}$ & $29^{8}$ & 217,865 & 80 & $+11 \cdot 5$ & 9,093 \\
\hline
\end{tabular}

The head-quarters of these are at the places from which each is named. The only town is Кон $\bar{A} T$, the administrative head-quarters of the District. The District also contains the military outposts of ThaL and ForT LOCKHART. The density of the population is low, and the population is too small in some villages to cultivate all the land. Muhammadans number 199,722 , or more than 91 per cent. of the total ; Hindus I 4,480; and Sikhs 3,344. The language commonly spoken is Pashtū; the Awāns and Hindus talk Hindkī, a dialect of Punjābi, among themselves, but know Pashtū as well.

Castes and The most numerous tribe in the District are the Pathāns, occupations. who number 134,000 , or 61 per cent. of the total population. They are divided into two main branches : the Bangash, who occupy the Mīranzai valley with the western portion of the Kohāt tahsil; and the Khattaks, who hold the eastern part of Kohāt and the Teri tahsil up to the Indus. The Khattaks are inferior as cultivators but make better soldiers than the Bangash. Next in importance to the Pathāns come the Awāns $(22,000)$, who live along the banks of the Indus and are probably immigrants from Rāwalpindi District. Saiyids number 8,000. Of the commercial and money-lending classes the Aroras $(8, \infty 00)$ are the most important, the Khattris numbering only 3,000, and Parāchas (carriers and pedlars) 2,000. The Shaikhs, who mostly live by trade, number 3,000 . Of the artisan classes, the Tarkhāns (carpenters, 4,000), Lohars (blacksmiths, 4,000), and Mochis (shoemakers and leatherworkers), Kumhārs (potters) and Julāhās (weavers), each returning 2,000, are the most important; and of the menials, only the Nais (barbers, 3,000) and Chūhrās or Kutānas (sweepers, 2,000) appear in any numerical strength. In r9or the District contained 145 native Christians, but no mission has been established. Agriculture supports 68 per cent. of the population.

General agricul-

In the low-lying tracts along the bottom of the main valleys 
the soil is generally a good loam, fertile and easily worked. tural conThe silt brought down by the mountain torrents is poor and thin, but the land is as a rule well manured. In the western portion of the Hangu tahsil there are stretches of a rich dark loam, which yields good autumn crops in years of seasonable summer rains. But the predominant soil in the District is clay, varying from a soft and easily ploughed soil to a hard one, which is useless without a great deal of water. The clay is often brick-red in colour, and this, too, is found both soft and hard. The soft red clay is an excellent soil, holding water well, and needing no manure if cropped only once a year. Towards the Indus the level land, which alone can be cultivated, has a thin sandy soil covered in many places almost entirely with stones; these help to keep the soil cool, and without them crops could not live on the thin surface soil. Agricultural conditions, however, depend chiefly on the presence or absence of water. The spring crop, which in r $903^{-4}$ occupied $5^{8}$ per cent. of the area harvested, is sown from October to January; the autumn crop mainly in June, July, and August, though cotton and great millet are often sown in May.

The following table shows the main statistics of cultivation Chief agriaccording to the revenue returns for $1903-4$, the areas being cultural in square miles :-

\begin{tabular}{|c|c|c|c|c|c|c|}
\hline \multicolumn{2}{|c|}{ Tahsil. } & \multirow{2}{*}{$\begin{array}{r}\text { Total. } \\
811 \\
1,616 \\
546\end{array}$} & \multirow{2}{*}{$\begin{array}{c}\text { Cultivated. } \\
\begin{array}{r}107 \\
300 \\
54\end{array}\end{array}$} & \multirow{2}{*}{$\begin{array}{r}\text { Irrigated. } \\
43 \\
3 \\
15\end{array}$} & \multirow{2}{*}{$\begin{array}{c}\begin{array}{c}\text { Cultivable } \\
\text { waste. }\end{array} \\
186 \\
182 \\
54\end{array}$} & \multirow{2}{*}{$\begin{array}{c}\begin{array}{c}\text { Not available } \\
\text { for } \\
\text { cultivation. }\end{array} \\
518 \\
1,124 \\
437\end{array}$} \\
\hline $\begin{array}{l}\text { Kohāt } \\
\text { Teri . } \\
\text { Hangu }\end{array}$ & . $\quad$ • & & & & & \\
\hline & Total & 2,973 & $4^{61}$ & 61 & $4^{22}$ & 2,079 \\
\hline
\end{tabular}
statistics and principal crops.

The chief food-crops are wheat, covering 173 square miles, or 44 per cent. of the cultivated area, and bäjra, roz square miles, or 26 per cent. Smaller areas are occupied by gram (30), maize (24), barley, pulses, and jowär. Very little rice or cotton is produced.

The cultivated area has apparently decreased by 3 per cent. Improvesince the previous settlement, as the lightness of the revenue ments in demand afforded no inducement for keeping the poorer soils tural under the plough, and no improvements have been made in practice. agricultural methods. There is, however, room for expansion of cultivation, especially in Mirānzai. Advances for the repair of embankments and watercourses are in some demand, and 
Rs. 36,100 was lent during the five years ending 1903-4 under the Land Improvement Loans Act. During the same period Rs. 3I,500 was advanced under the Agriculturists' Loans Act for the purchase of seed and bullocks.

Cattle, The cattle bred locally are of poor quality, and animals are ponies, largely imported from the Punjab. Camels are bred in large and sheep. numbers. Both the fat-tailed and ordinary breeds of sheep are found, and large flocks of goats are kept. The local breed of horses is fair. Two pony and two donkey stallions are maintained by the municipality and the District board.

Irrigation. Out of the total cultivated area of 461 square miles, only 6r square miles, or 12 per cent., were irrigated in 1903-4. Of this area, 3.4 square miles were supplied by wells and 53.8 square miles by streams and tanks, in addition to which 4 square miles are subject to inundation from the Indus. There were $4 \mathrm{I} 3$ masonry wells worked by bullocks with Persian wheels, and I 75 unbricked wells and water-lifts. The most effective irrigation is from perennial streams; but agriculture, especially in Miranzzai, is much benefited by the building of tanks and embankments to hold up rain-water.

Forests. The District contains 74 square miles of unclassed forest and Government waste under the management of the DeputyCommissioner. Parts of the hill tracts are covered with dwarfpalm (mazri). The District as a whole is not well wooded, though where water is obtainable road-side avenues have been planted, in which the mulberry, Persian lilac (bakain), willow, and shisham are preponderant. Elsewhere the wild olive, the palosi (Acacia modesta), and other species of acacia are the commonest trees. The summit of the Sāmāna has been almost denuded of trees, but in sheltered places ilex, walnut, and Scotch fir are found.

Mines and The salt-producing areas, from which salt has been excavated minerals. from time immemorial, occupy a tract about 50 miles long with a nearly uniform width of 20 miles. The KoHĀt Salt QUARRIES at present worked are at Jatta, Mālgīn, Kharak, and Bahādur Khel, of which the last presents perhaps the greatest amount of exposed rock-salt to be seen in the world. The average sales of salt for the three years ending $1903-4$ exceeded 1 5,307 tons. The District contains three petroleum springs, which would yield perhaps half a gallon a day if the oil was gathered daily, but it is only occasionally taken. Sulphur is found in the hills to the south of the Kohāt Toi, and limestone and sandstone all over the District, but they are not regularly quarried. 
The District possesses very few handicrafts and no manu- Arts and factures. Kohāt used to be celebrated for its rifles, in which manufaca high degree of excellence was attained, considering the rude nature of the appliances; but the industry not being encouraged has now departed to the independent villages of the Kohāt Pass, where it flourishes. Coarse cotton cloth is made throughout the District, but not in sufficient quantities to supply even the local demand. Turbans of excellent texture and colour are woven of both silk and cotton at Kohāt and the adjoining villages, and coloured felt mats are made; woollen camel-bags and leather sandals are also produced. The dwarf-palm is used to a very large extent for the manufacture of sandals, ropes, mats, matting, and baskets.

A large and increasing trade with Tîrāh and Kābul passes Commerce through the District by the Khushālgarh-Kohāt-Thal Railway, and trade. but the imports and exports apart from this through traffic are not large. Salt, agricultural produce, and articles made of the dwarf-palm, which grows plentifully throughout the District, are the principal exports, and piece-goods and iron the principal imports. Kohāt, Thal, and Naryāb are the chief trade centres.

The District is traversed by the 2 feet 6 inches gauge rail- Communiway from Khushālgarh to Thal, opened in 1903 . The line at cations. once came into universal use for the conveyance of passengers and goods, and has proved an unexpected commercial success. It is being converted to the broad gauge, which will be opened on the completion of the bridge over the Indus at Khushalgarh. Mails and passengers are conveyed by tonga from Peshāwar to Kohāt over the Kohāt Pass and on to Bannu. There are 179 miles of Imperial metalled roads, and 509 miles of unmetalled roads. Of the latter, $13 \mathrm{I}$ miles are Imperial, and 378 belong to the District board. Besides the Peshāwar-Kohāt-Bannu road, the most important routes are those from Khushālgarh through Kohāt to the Kurram at Thal and from Khushālgarh to Attock. There is little traffic on the Indus, which has a very swift current in this District; it is crossed by a bridge of boats at Khushālgarh, now being replaced by a bridge which both road and rail will cross.

The District was classed by the Irrigation Commission as Famine. secure from famine. The crops matured in the famine year of I 899-r 900 amounted to 77 per cent. of the normal.

The District is divided for administrative purposes into District three tahsils, each under a tahsildär and naib-tahsildār. The subdiviDeputy-Commissioner has political control over the trans- staff. border tribes in adjoining territory: namely, the Jowāki and 
Civil justice and crime.
Land revenue.

Pass Afrīdis, the Sepaiah Afrīdis (Sipāhs), the Orakzai Zaimukhts, the Biland Khel and Kābul Khel Wazìrs. Under him are two Assistant Commissioners, one of whom is in charge of the Thal subdivision and exercises political control, supervised by the Deputy-Commissioner, over the tribes whose territories lie west of Fort Lockhart on the Sāmāna range. Two Extra Assistant Commissioners, one of whom is in charge of the District treasury, complete the District staff. One member of the staff is sometimes invested with the powers of an Additional District Magistrate.

The Deputy-Commissioner as District Magistrate is responsible for criminal justice, and in his capacity of District Judge has charge of the civil judicial work. $\mathrm{He}$ is supervised by the Divisional Judge of the Derajāt Civil Division, and has under him a Subordinate Judge, whose appellate powers relieve him of most of the civil work, a Munsif at headquarters, and an honorary civil judge at Teri. Crime is still very frequent and serious offences preponderate; but the advance in law and order during late years, especially since the Mīrānzai expedition of 1891 , has been considerable.

The early history of Kohāt, fiscal as well as political, is vague and uncertain. Under the Mughals and Afghāns leases were granted in favour of the Khāns, but few records remain to show even the nominal revenue. In 1700 the emperor Aurangzeb leased Upper and Lower Mirānzai to the Khān of Hangu for Rs. 12,000 . In r8ro the Kohăt tahsil was leased for Rs. 33,000. In $r 836$ Ranjit Singh assigned the revenue of the whole of the present District to Sultān Muhammad Khān, Bārakzai, in return for service. This revenue was estimated at I $\frac{1}{2}$ lakhs.

After annexation four summary settlements were made of the Kohāt and Hangu tahsils, which reduced the demand from one lakh to Rs. 75,000 . In 1874 a regular settlement of the Kohāt and Hangu tahsils was begun, excluding three tappas which were settled summarily. The rates fixed per acre varied from Rs. 6-8 on the best irrigated land to 3 annas on the worst 'dry' land; and the total assessment was Rs. $1,08,000$ gross, an increase of 18 per cent. on the previous demand. So large a sum was granted in frontier remissions and other assignments that the net result to Government was a loss of Rs. 5,000 in land revenue realizations. The object of the settlement, however, was not so much to increase the Government demand as to give the people a fair record-of-rights. The increasing peace and security along this part of the border, 
culminating in the complete tranquillity which has characterized it since 1898 , has worked an agricultural revolution in Upper Mīrānzai.

The Teri tahsil, which forms half the District, has a distinct fiscal history. The Khān of Teri has always paid a quit rent, which was Rs. 40,000 under the Bărakzai rulers, and was fixed at Rs. 31,000 on annexation. Since then it has been gradually lowered to Rs. 20,000, at which it now stands. During the Afghān war the Khān's loyalty to the British exceeded that of his people, who resented the forced labour then imposed upon them by the Khann. Consequently at the close of the war a veiled rebellion broke out in Teri. It was therefore decided that the tract should be settled, and a settlement was carried out in $1891-4$, the chief object being to place on a satisfactory footing the relations between the Khān and the revenuepayers.

In I 900 the first regular settlement of Upper Mirānzai and the revision of settlement in the rest of the District was begun. This was completed in 1905 and resulted in a net increase of Rs. 59,000 in the revenue demand, which amounted to Rs. $1,28,000$. The rates of the new settlement per acre are: 'dry' land, maximum Rs. I-r2, minimum 3 annas ; and 'wet' land, maximum Rs. 7-12, minimum R. 1 .

The total collections of revenue and of land revenue alone have been as follows, in thousands of rupees :-

\begin{tabular}{|c|c|c|c|c|c|}
\hline & & $1880^{-1}$ & $1890-1$. & $1900-1$. & $1903-4$. \\
\hline $\begin{array}{l}\text { Land revenue } \\
\text { Total revenue }\end{array}$ & . $\quad:$ & $\begin{array}{l}9 \circ \\
93\end{array}$ & $\begin{array}{l}79 \\
90\end{array}$ & $\begin{array}{l}85 \\
94\end{array}$ & $\begin{array}{l}74 \\
83\end{array}$ \\
\hline
\end{tabular}

The District contains only one municipality, КоHĀT town. Local and Outside this town, local affairs are managed by a District municipal. board, whose income is mainly derived from cesses. The income in 1903-4 amounted to Rs. 14,100 and the expenditure to Rs. 16,300 , education forming the largest individual charge.

The regular police force consists of 527 of all ranks, of Police and whom 44 are municipal police. The village watchmen number jails.

265. There are 12 police-stations, 16 road-posts, and 4 outposts. The border military police, who are amalgamated with the local militia (the Sāmāna Rifles) are under a commandant, assisted by a. British adjutant and quartermaster, all of whom are officers of the regular police force. The control of the commandant is exercised subject to the orders of the Deputy- 
Commissioner. The force, which numbers 1,023 of all ranks, garrisons 23 posts for maintaining watch and ward on the border. The District jail at head-quarters can accommodate nearly 300 prisoners.

Education. Only 4.2 per cent. of the population $(7 \cdot 2$ of males and 0.3 of femates) could read and write in r 901 . The proportion is markedly higher amongst Sikhs (39.I per cent.), and Hindus (29.5), than among the agricultural Muhammadans ( 1.6 per cent.). Owing to the difficulties of communication and the poverty of the District board, education continues to be very backward, and the percentage of literacy compares unfavourably with that of the Province generally. The number of pupils under instruction was 375 in $1880-1,536$ in $1890-x$, 908 in $1900-1$, and 1,260 in $1903-4$. In the last year there were 2 secondary and 28 primary (public) schools, and 55 elementary (private) schools, the number of girls being 90 in the public and 230 in the private schools. The total expenditure was Rs. 16,000 , of which fees brought in Rs. 2,400, the District fund contributed Rs. 5,000, the municipality Rs. 6,800, and Imperial revenues Rs. 2,600.

Hospitals Besides the civil hospital at Kohāt, and a branch in the city and dispensaries.

for females, the District possesses two dispensaries, at Hangu and Teri. The hospitals and dispensaries contain 57 beds. In 1904, the number of cases treated was 53,499 , including 1, 106 in-patients, and 2,100 operations were performed. The income was Rs. 10,800, Government contributing Rs. 3,800 and municipal and District funds Rs. 7,000. Vaccina- The number of successful vaccinations in $1903-4$ was $95 \mathrm{I}$,
tion. representing 44 per 1,000 of the population. The Vaccination Act has been in force in Kohāt since 1903 .

[District Gazetteer, 1879 (under revision).]

Kohāt Tahsī1.-Tahsil of Kohāt District, North-West Frontier Province, lying in two portions between $33^{\circ} 22^{\prime}$ and $33^{\circ} 45^{\prime} \mathrm{N}$. and $71^{\circ} 5^{\prime}$ and $71^{\circ} 40^{\prime} \mathrm{E}$., and $33^{\circ} 3^{\prime}$ and $33^{\circ} 20^{\prime} \mathrm{N}$. and $71^{\circ} 27^{\prime}$ and $71^{\circ} 46^{\prime}$ E., with a total area of $8 \mathrm{II}$ square miles. The tahsil is divided into two parts, separated by an extension of the Teri tahsil reaching to the foot of the Afrīdi hills, by which the District is bounded on the north. The western portion, which contains the town and cantonment of Kohāt, consists of the valley of the Kohāt Toi, after its issue from Lower Mirannzai and the adjacent hills. The other part is a strip of barren and fairly level country along the right bank of the Indus north of Khushalgarh. The population in 1901 was $79,60 \mathrm{r}$, compared with 69,984 in $189 \mathrm{r}$. It 
contains the town of $\mathrm{KоH} \overline{\mathrm{A}} \mathrm{T}(30,762)$, the tahsil and District head-quarters, and 89 villages. The land revenue and cesses amounted in $1903-4$ to Rs. 90,000 .

Teri Tahsīl--Tahsīl of Kohāt District, North-West Frontier Province, lying between $32^{\circ} 4^{\prime}$ and $33^{\circ} 44^{\prime} \mathrm{N}$. and $70^{\circ} 33^{\prime}$ and $72^{\circ} 1^{\prime}$ E., with an area of 1,616 square miles. The population was 94,363 in 1901 , and 85,460 in 1891 . The tahsil contains 166 villages, its head-quarters being at a village of the same name. The land revenue and cesses amounted in 1903-4 to Rs. 95,000. Teri is inhabited by the Khattak tribe of Pathāns, whose present chief, Khān Bahādur Abdul Ghafūr Khān, Khān of Teri, holds the whole tahsīl in jāgīr at a quitrent of Rs. 20,000 in perpetuity, while as between the Khān and the zamindarrs the demand is revised when the term of each settlement expires. The country, though hilly, is fairly well cultivated. The Khattaks are a fine race, who make excellent soldiers; and though naturally wild and impatient of control, they are settling down under British rule into peaceable agriculturists and carriers.

Thal Subdivision.-Subdivision of Kohāt District, NorthWest Frontier Province, consisting of the HaNGU TaHsì The subdivisional officer is also Political officer for the following tribes: Orakzai west of Fort Lockhart, Zaimukhts, Biland Khel and Kābul Khel Wazìrs.

Hangu Tahsīl (or Mīrānzai).-Western tahsil of Kohāt District, North-West Frontier Province, lying between $33^{\circ} 19^{\prime}$ and $33^{\circ} 36^{\prime} \mathrm{N}$. and $70^{\circ} 30^{\prime}$ and $71^{\circ} 13^{\prime}$ E., with an area of 546 square miles. It consists of the Mirannzai valley, which is inhabited by a tribe of Bangash Pathāns, and is divided into the tappas of Upper and Lower Mīrānzai. Lower Mīrānzai slopes east towards Kohāt, the valley being bounded on the north by the Sāmāna range which separates it from Orakzai Tîanh, and on the south by the low hills of the District, of which Mĩr Khweli $(4,500)$ is the highest. Upper Mirrānzai slopes west towards the Kurram. On the north are the hills of the Ali Khel Orakzai, the Māmuzai, and the Zaimukhts, and on the south the Khattak hills. Both valleys are watered by perennial streams and are fertile, while the hills provide excellent grazing for sheep and goats. Upper or Western Mīānzai was annexed in $185 \mathrm{I}$, but British administration was not established till 1855 . The population of the whole tahsil in 1901 was 43,901 , compared with 39,704 in 1891 . It contains 43 villages, including Hangu, the head-quarters. The land revenue and cesses amounted in 1903-4 to Rs. 36,000. 
Hangu Village.-Head-quarters of the tahsil of the same name in Kohāt District, North-West Frontier Province, situated in $33^{\circ} 32^{\prime} \mathrm{N}$. and $71^{\circ} 5^{\prime} \mathrm{E}$. The officer in charge of the Thal subdivision has his head-quarters here. The site is a very old one, and is mentioned by the emperor Bābar in his memoirs. The Khushālgarh-Kohāt-Thal branch of the North-Western Railway has a station at Hangu, 26 miles from Kohāt. The garrison consists of a detachment of native cavalry, the headquarters of the Sāmāna Rifles, and (in winter) two guns of a mountain battery. The village contains a Government dispensary and a vernacular middle school maintained by the District board.

Kohăt Town.-Head-quarters of the District and tahsil of the same name, North-West Frontier Province, situated in $33^{\circ} 35^{\prime} \mathrm{N}$. and $71^{\circ} 26^{\prime} \mathrm{E}$., on the Khushālgarh-Thal branch of the North-Western Railway, 30 miles from Khushālgarh. Population (1901), 30,762, of whom 19,807 are Muhammadans, 7,833 Hindus, and 2,832 Sikhs. The population in the cantonment, included in the above total, was 12,670 . The present town of Kohāt has sprung up since annexation. It lies in an amphitheatre of hills at some distance from the site of the old town, which is said to have been founded by the Bangash in the fourteenth century. It is built on undulating ground with excellent natural drainage. The cantonment and civil station stand on high ground to the east and north-east of the native town. The garrison consists ordinarily of a mountain battery, some frontier garrison artillery, one native cavalry regiment, and three native infantry regiments. The municipality was constituted in 1873 . The income during the ten years ending 1902-3 averaged Rs. 40,700, and the expenditure Rs. 36,000. In 1903-4 the income was Rs. 50,500, chiefly derived from octroi, and the expenditure was Rs. 83,400 . This sum includes an investment of Rs. 30,000 in Government securities. The receipts and expenditure of cantonment funds during the ten years ending 1902-3 averaged Rs. 5,600 and Rs. 5,500 respectively. The chief public institutions are the Anglo-vernacular high school maintained by the municipality, a civil hospital, and a female hospital. The town is of no commercial importance, but has a small manufacture of lungis or turbans. Rifles used to be made at the neighbouring village of Jangal Khel, but the industry is now quite extinct.

Kohāt Salt Quarries.-The Kohāt District of the NorthWest Frontier Province possesses important salt quarries at Jatta (or Jatta Ismail Khel), Mālgīn, Kharak, and Bahādur 
Khel, lying in the east and centre of the District. Bahādur Khel, on the Bannu border, contains about forty quarries and Jatta sixteen. At the former place a mass of rock-salt crops out between two hills, 8 miles long by $\frac{1}{4}$ broad, the quarries worked lying in a small part of this area. Kohät salt is grey to black in colour, and less esteemed than that of the Salt Range, though analysis shows it to be of good quality. It is purchased by traders direct from the miners under the supervision of the preventive establishment, which consists of two superintendents at Bahādur Khel and Jatta, an assistant superintendenf at Mālgīn, 5 inspectors, and 334 subordinates. Numerous outcrops have to be watched. The quantity excavated in $1903-4$ was 16,493 tons, paying a duty of Rs. $6,73,961$. The gross income for the six years ending I 902-3 averaged Rs. 6,63,825. The salt is largely exported beyond the border and to Afghānistān, but it also supplies the four Districts of the Province which lie west of the Indus. The export trade is chiefly in the hands of Ghilzai, Mohmand, Afrīdi, and other trans-border traders.

Lockhart, Fort. - Military outpost on the Sāmāna range, in the Hangu tahsīl of Kohāt District, North-West Frontier Province, and summer head-quarters of the general commanding the Kohāt military district, situated in $33^{\circ} 33^{\prime} \mathrm{N}$. and $70^{\circ}$ $55^{\prime}$ E., 6,743 feet above the sea-level. The garrison consists of a native infantry regiment, and in summer a mountain battery.

Sāragarhi.-Village on the crest of the Sāmāna range, Kohāt District, North-West Frontier Province, situated in $33^{\circ}$ $55^{\prime} \mathrm{N}$. and $70^{\circ} 45^{\prime} \mathrm{E}$. It is held by the Bābi Khel, a section of the Rabia Khel Orakzai. During the Mirannzai expedition of $\mathrm{I} 8 \mathrm{~g}$, the village was destroyed after severe fighting and an outpost was built. In 1897 this post, then held by 21 men of the 36 th Sikhs, was attacked by several thousand Orakzais, who overwhelmed the little garrison after a heroic defence and massacred the Sikhs to a man on September I2. A monument at Fort Lockhart commemorates the gallantry of the defence, while other memorials have been erected at Amritsar and Ferozepore in the Punjab.

Thal Village.-Military outpost in the Hangu tahsil of Kohāt District, North-West Frontier Province, situated in $33^{\circ}$ $20^{\prime} \mathrm{N}$. and $70^{\circ} 34^{\prime} \mathrm{E}$., on a branch of the North-Western Railway. Thal is a dépôt for the through trade with Northern Afghānistān, which passes along the Kurram valley. It also does some local trade with the tribesmen of independent 
territory adjoining. The village lies on the left bank of the Kurram river, at the extreme limit of British territory, and gives its name to a subdivision of the District. The fort is garrisoned by detachments of native cavalry and infantry under a British officer. A new border military police post and civil resthouse were built here in 1905 .

Boun- Bannu District.-One of the four Trans-Indus Districts faries, con- of the North-West Frontier Province, lying between $32^{\circ} 16^{\prime}$ and hill and $33^{\circ} 5^{\prime} \mathrm{N}$. and $70^{\circ} 23^{\prime}$ and $71^{\circ} 16^{\prime}$ E., with an area of and river systems. I,670 square miles. The District forms a circular basin, drained by two rivers from the hills of Wazīistān, the Kurram and the Gambīla or Tochi, which unite at Lakki and flow into the Indus south of Kālābāgh. It is shut in on every side by mountains : on the north by those in the Teri tahsil of Kohat District ; on the east by the southern extremity of the Maidanni Pahār or Khattak Niāzi range and the northern spur of the Marwat range, which separate the District from the Isa Khel tahsil of Miānwāli District in the Punjab; on the south-east and south the Marwat and Bhittanni ranges divide it from Dera Ismail Khān; and on the west and north-west lie Wazīristān and independent territory inhabited by the Bhittanni tribe. These hills nowhere attain any great height. The highest point of the Maidāni range at its centre, near the hamlet and valley of Maidān, has an altitude of only 4,256 feet. The Marwat range culminates in Sheikh Budin, the hill which rises abruptly from its south-west end to a height of 4,516 feet and forms the summer retreat for this District and Dera Ismail Khān. From these ranges numerous spurs jut out into the Bannu plains, but no other hills break their level expanse. Of the rivers the larger is the Kurram, which, entering the District at its north-western corner close to Bannu town, runs at first south-east, then south, and finally winds eastward through the Darra Tang or 'narrow gorge' which lies between the extremities of the Maidāni Pahār and Marwat ranges. The Tochi river enters the District about 6 miles south of the Kurram and flows in the same direction, gradually drawing closer to it until their streams unite about 6 or 7 miles west of the Darra Tang. Between these rivers, and on the left bank of the Kurram in the upper portion of its course, lie the only tracts which are perennially irrigated. For the first 10 miles of its passage through the District the Kurram runs between banks of stiff clay which rise abruptly to a height of ro to 30 feet, and its bed is full of stones and boulders; but lower down it spreads over long stretches of marsh land. Its flow 
is rapid, but it is highly charged with a rich silt which renders it most valuable for irrigation.

At the south-east edge the western flanks of the hills bounding Geology. Miānwāli and Dera Ismail Khān Districts expose Tertiary lower Siwālik soft sandstone, and upper Siwālik conglomerates, a thickness of which dips regularly under the alluvium and gravels forming the greater part of the great Bannu plain. On its western side the border area has been examined along one line of route only, namely, the Tochi valley ${ }^{1}$. Here long ridges striking north and south expose upper and lower Siwāliks, -Nummulitic limestone, sandstone and shales, some mesozoic limestone in the ridge east of Mirām Shāh, and a great mass of Tertiary igneous rocks (diorites, gabbros, and serpentines) west of Muhammad Khel.

In the irrigated portions of the District trees abound of the Botany. same species as are common in Peshāwar; elsewhere there is little but thorny shrubs of the same kinds as are found in Kohāt. The more common plants are Reptonia buxifolia, Dodonaea viscosa, Capparis aphylla, Flacourtia sapida, F. sepiaria, several species of Grewia, Zizyphus nummularia, Acacia Jacquemontii, Alhagi camelorum, Crotalaria Burhia, Prosopis spicigera, several species of Tamarix, Nerium odonum, Rhazya stricta, Calotropis procera, Periploca aphylla, Tecoma undulata, Lycium europaeum, Withania coagulans, $W$. somnifera, Nannorhops Ritchieana, Fagonia, Tribulus, Peganum Harmala, Calligonum polygonoides, Polygonum aviculare, P. plebejum, Rumex vesicarius, Chrozophora plicata, and species of Aristida, Anthistiria, Cenchrus, and Pennisetum.

Bears occasionally come from Wazīistān and leopards Fauna. still frequent the hills, while hyenas are sometimes found where there are ravines. Wolves are common, rewards having been paid for destroying 168 from 1900 to 1904 . The Sulaimāni mārkhor is found on all the higher hills, including Sheikh Budin. Uriāl are also to be found in the hills, and 'ravine deer' (gazelle) in the neighbourhood of Jāni Khel.

The general elevation of the plains is about $\mathrm{x}, 000$ feet, and Climate the temperature would be much the same all over the District and temdid not special local causes affect it. Trees, excessive irrigation round the town, and the closeness of the hills combine to make Bannu moist and close in the hot season, and to equalize the temperature throughout the twenty-four hours. The sandy plain of Marwat is hotter by day and cooler by night, and far

I F. H. Smith, 'Geology of the Tochi Valley,' Records, Geological Survey of India, vol. xxviii, part ii. 
more healthy in spite of the intense heat. Fevers are common from September to November, and respiratory diseases cause considerable mortality.

Rainfall. The annual rainfall averages $12 \frac{1}{2}$ inches, rarely rising above 16 , but at Bannu in $189 \mathrm{r}-2$ less than 5 inches fell in the year. The fall is frequently unseasonable.

History. The population of Bannu is, and has been for many centuries, essentially Afghān. There are, however, remains which tell of an older Hindu population, and afford proof that the District came within the pale of the ancient Graeco-Bactrian civilization of the Punjab. The close of the era of prosperity indicated by these remains is attributed in local tradition to the ravages of Mahmūd of Ghazni, who is said to have utterly demolished the ancient Hindu strongholds, leaving no stone standing upon another. For upwards of a century the country appears to have lain waste, till at length the Bannu valley was gradually colonized by immigrants from the western hills, the Bannuwāls or Bannūchis, who still remain, and the Niāzai, who subsequently gave place to the Marwats. The advent of the Marwats is placed in the reign of Akbar. The Niãzai, whom they expelled, spread across the Khattak-Niāzai hills, and colonized the plains upon both banks of the Indus. The Marwats still hold the southern portion of the Bannu valley.

At this time, and for two centuries later, the country paid a nominal allegiance to the Delhi emperors. In $173^{8}$ it was conquered by Nādir Shah, who laid it completely waste. Ahmad Shāh Durrāni subsequently led his army three or four times through the Bannu valley, levying what he could by way of tribute on each occasion. So stubborn, however, was the opposition of the inhabitants, that neither conqueror made any attempt to establish a permanent government. In 1818 the Nawāb of Mankerā annexed Marwat, but was speedily forced to give way to Ranjit Singh, who first crossed the Indus in 1823 . From that year to $183^{6}$ the Sikh troops and those of the Nawãb in turn harried the country. In $183^{8}$ the valley passed by cession to the Sikhs. Ranjit Singh lost no time in attempting to occupy his new territory. Elsewhere in the District he had met with little opposition; but in the Bannu valley he was forced, after several efforts, to fall back upon the expedient of his predecessors, and to content himself with the periodical dispatch of a force to levy what he was pleased to term arrears of revenue: in reality to devastate the country, and carry off whatever booty could be secured.

Such was the state of affairs when, after the first Sikh 
War, the District was first brought under British influence. In the winter months of $1847-8$, Lieutenant (afterwards Sir Herbert) Edwardes was dispatched to the frontier as the representative of the Lahore Darbār, and accompanied by a Sikh army under General Van Cortlandt. Arrived in Bannu, he found a large portion of the District practically independent. In the Bannu valley every village was a fort, and frequently at war with its neighbours, while the Wazir tribes on the frontier were ever seeking opportunities for aggression. Within a few months Edwardes reduced the country to order, effecting a peaceful revolution by the force of his personal character, and without the firing of a single shot. The forts were levelled; arrangements were made for the collection of a regular revenue ; and so effectual were his measures that on the outbreak at Multann he was able to hurry to the scene of action with a force of levies from this District, who served loyally throughout the campaign. The Sikhs in garrison at Edwardesābād meanwhile rose against their officers, and, having murdered them, marched to join their brethren in arms. A force from the hills at the same time invaded the District, but was held at bay by Lieutenant Reynell Taylor, Edwardes's successor. In the following year the Punjab was annexed, and the District passed without a blow under British administration. The area covered by the present District at first belonged to Dera Ismail Khān. In I86I the District of Bannu was constituted, comprising the present District and the Miānwāli and Isa Khel tahsīls of what is now the Miānwāli District of the Punjab, which were taken away on the creation of the Frontier Province in rgor. The even tenor of administration has been at times disturbed by frontier raids, but no trouble has at any period been given by the inhabitants of the District itself. During the Mutiny of 1857 the country remained perfectly quiet. The border is guarded by a chain of outposts, eleven in number.

At Akra and other places in the Bannu valley mounds of Archaeovarious sizes exist where, amid fragments of burnt brick and logy. tiles, of broken images and Hindu ornaments, coins occur with Greek or pseudo-Greek inscriptions. The Akra mound near Bannu presents features of great antiquarian interest. This mound, which at its highest point does not rise more than 70 feet above the surrounding plain, has long been excavated by the inhabitants of the neighbouring villages, who find the soil of its 'culture stratum,' generally about 2 to 3 feet in thickness and composed of ashes, rubbish, and bones, to be possessed of valuable properties as manure. Above this 
'culture stratum' are layers of earth lighter in colour, and ranging from 8 to 20 feet in thickness. These probably represent the débris accumulated during centuries from structures of clay or sun-dried brick. In these layers are found plentiful fragments of ancient pottery and hard bricks, as well as rubble. The coins, terra-cotta figures, and fragments of small sculptures representing Hindu deities, which have been unearthed from this mound, point to the period from the first century B.c. down almost to the advent of the Muhammadan conquerors as that in which the site was inhabited. There is a curious resemblance in character and contents between the layers composing the Akra mound and the 'culture strata' of the ancient capital of Khotan in Chinese Turkestān.

The Bannu District contains 2 towns and 362 villages. The people. population at the last three enumerations was: (188r) I 82,740, (189r) 204,469, and (I90r) 226,776. It increased by ro.9 per cent. during the last decade, the increase being greater in the Marwat tahsil than in that of Bannu. It is divided into two tahsils, of which the head-quarters are at the municipalities of BANNU, the head-quarters of the District, and LAKKI. Statistics according to the Census of I90I are shown below :-

\begin{tabular}{|c|c|c|c|c|c|c|c|}
\hline \multirow[b]{2}{*}{ Tahsil. } & \multirow{2}{*}{  } & \multicolumn{2}{|c|}{ Nuinber of } & \multirow{2}{*}{  } & \multirow{2}{*}{ 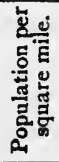 } & \multirow{2}{*}{ 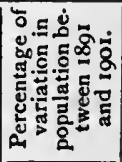 } & \multirow{2}{*}{  } \\
\hline & & $\stackrel{\dot{0}}{\tilde{z}}$ & 总 & & & & \\
\hline $\begin{array}{l}\text { Bannu . } \\
\text { Marwat . }\end{array}$ & $\begin{array}{r}443 \\
\mathrm{I}, 198\end{array}$ & $\begin{array}{l}\text { I } \\
\text { I }\end{array}$ & $\begin{array}{l}217 \\
145\end{array}$ & & $\begin{array}{r}294 \\
80\end{array}$ & $\begin{array}{r}+\quad 8.4 \\
+\quad 14.5\end{array}$ & \\
\hline Total & $1,64^{1} *$ & 2 & 362 & 226,776 & $13^{8}$ & + & 9537 \\
\hline
\end{tabular}

* The difference between this figure and that given on $p .182$ is due to the exclusion here of the non-revenue-paying portion of the administrative District.

Muhammadans number 201,720 , or more than 89 per cent. of the total ; Hindus 22, 178 ; and Sikhs 2,673. Pashtū is the language of the District, but Hindki is also spoken among the Castes and non-Pathān element. About 129,000 persons, or 56 per cent. occupations. of the population, are Pathāns. Of these the most numerous group is that of the Marwats $(52,000)$, who live mainly in the tahsil named after them. In person, they are tall and muscular ; in bearing, frank and open. Almost every officer who has administered the District has left on record a favourable mention of them. To these the Bannūchis $(30,000)$ form a painful contrast. They are indubitably of mixed descent, and 
exhibit every Afghān vice, without possessing the compensating virtues of bravery and self-confidence. They are generally small in stature and inferior in physique, sallow and wizened in appearance, and in disposition mean and revengeful. They are, on the other hand, industrious cultivators, and have been uniformly quiet and submissive subjects to the British Government. The Wazìrs in this District, all Darwesh Khel, number 24,000. They are divided into two great sections, the Utmanzai and the Ahmadzai. Last come the Bhittannis $(2,000)$, who live on the border of the District on the southern slopes of the Gabar mountain. In the District itself they are recent settlers. Besides the Pathān races, the chief of the Hindkīs, as they are called, are the Jats (I 5,000$)$ and Awāns $(9,000)$, all of whom live by agriculture, as do also the Bāghbāns $(2,000)$ and Rājputs $(3,000)$. Saiyids number 12,000 . The Aroras, the only important commercial and money-lending class, number 15,000; other castes of this class are the Bhātias and Khattrīs, numbering 2,000 and I,000 respectively. Of the artisan classes, the Tarkhāns (carpenters, 5,000), Lohārs (blacksmiths, 4,000), Rangrez (dyers, 3,000), Kumhārs (potters, 3,000), Sonārs (goldsmiths, 2,000), and Mochīs (shoemakers and leather-workers, 2,000) are the most important; and of the menials only the Nais (barbers, 3,000) and Chūhrās and Kutānas (sweepers, 2,000) appear in some strength. Agriculture supports 75 per cent. of the population.

The Church Missionary Society began work in Bannu in Christian I 864, and has a hospital which possesses a wide reputation on missions. both sides of the frontier. The District contained $6_{3}$ native Christians in rgor.

The prevailing soil is a sandy gravel, sometimes degenerating General into mere sand, as in the Marwat tahsil, and sometimes afford- agriculing a light and easy cultivation. The central portion of the tural conBannu valley, between the Kurram and the Tochi, is highly irrigated, and the demands on the soil are incessant. It is preserved, however, from exhaustion by the use of manure and the deposits of silt brought down by the Kurram river. Their fertility being thus renewed, the lands of a great majority of villages are sown year after year, for two harvests, without showing signs of deterioration. The rest of the District, with the exception of the tract between the Bhittanni hills and the Tochi, is sandy and entirely dependent on the rainfall. Saline efflorescence is common in parts of the District. The spring crop, which in 1903-4 occupied 80 per cent. of the area matured in the year, is sown chiefly from the beginning of 
October to the end of January; the autumn crop from May to July, though sugar is sown as early as March.

Chief agri- The village tenures of this District as a rule present few
cultural cultural
statistics peculiar features, and fall naturally under the standard comand princi-munal types recognized throughout the Province. An expal crops.

ception, however, exists in the customs once general and still surviving in a few Marwat villages, of the periodical redistribution of holdings among the shareholders. This custom is called the khulla vesh, literally 'mouth division,' and received official sanction at the last revenue settlement. Cultivation is chiefly carried on by peasant proprietors, and money-rents between tenant and landlord are rare. There are no large proprietors, and the land is minutely subdivided. The following table shows the main agricultural statistics in 1903-4, according to the revenue returns, areas being in square miles :-

\begin{tabular}{|c|c|c|c|c|c|}
\hline \multicolumn{2}{|c|}{ Tahsil. } & Total. & Cultivated. & Irrigated. & $\begin{array}{c}\text { Cultivable } \\
\text { waste. }\end{array}$ \\
\hline \multirow[t]{2}{*}{$\begin{array}{l}\text { Bannu } \\
\text { Marwat }\end{array}$} & \multirow{2}{*}{$\begin{array}{l}- \\
\text { Total }\end{array}$} & $\begin{array}{r}443 \\
1,198\end{array}$ & $\begin{array}{l}277 \\
534\end{array}$ & $\begin{array}{r}175 \\
67\end{array}$ & $\begin{array}{r}54 \\
268\end{array}$ \\
\hline & & $1,6_{4} I$ & $8 \mathrm{II}$ & 242 & 322 \\
\hline
\end{tabular}

Wheat is by far the most important crop, covering 334 square miles in $1903-4$, or 49 per cent. of the net cultivated area. Next in importance is gram (158), after which the areas occupied by individual crops diminish rapidly, but maize (52) and $b \overline{a j} r a$ (4r) may be mentioned. Sugar-cane, cotton, and rice are grown to a small extent.

Improve- The area cultivated in 1903-4 had risen by 43 per cent. ments in agricultural practice. above that cultivated at the settlement of $1872-9$, the increase being chiefly due to the more peaceful state of the District. Little has been done as yet in the way of improving the quality of the crops grown. The amount of advances outstanding under the Land Improvement Loans Act at the end of $1903-4$ was Rs. 14,267 , while that of advances under the Agriculturists' Loans Act was Rs. 15,483 . The amounts advanced in 1903-4 under these two Acts were Rs. 300 and Rs. 9,270 respectively. There is a constant demand for loans to buy plough bullocks.

Cattle, The quality of the cattle is poor, and the attempt to introponies, duce Hissār bulls into the District was a failure. The buffaand sheep. loes, however, are of an excellent breed. Large numbers of camels and donkeys are kept in the Marwat tahsil, and of fat- 
tailed sheep in the Bannu tahsil. The Wazir breed of horses used to be popular, but is now virtually extinct, though the District is well adapted for horse-breeding. The District board maintains 2 horse and 2 donkey stallions.

Of the total area cultivated in $1903-4,242$ square miles, or Irrigation. 30 per cent., were classed as irrigated ; of this, all but 93 acres irrigated from wells was supplied by canals. The canals take off from the Kurram and other hill streams, and are mostly the property of the people themselves, though in some cases the water belongs to the Government. Many date from an extreme antiquity.' Bābar, writing in $15 \circ 5$, says : 'the Bangash [Kurram] river runs through the Bannu territory, and by means of it chiefly the country is irrigated.' Many centuries of contention and compromise have evolved a most elaborate system of irrigation and rights in water, which is now administered by the Deputy-Commissioner.

The forest lands are quite insignificant, and outside the Forests. Bannu oasis the District is badly wooded.

Bannu possesses few minerals of commercial value. Rock-Minerals. salt exists, but is not worked ; and limestone, building stone, and flint are the only mineral products used. Impure carbonate of soda is made from the ashes of the Caroxylon Griffithii.

Cotton is woven in most villages, but in quantities only Arts and sufficient for local requirements. The woollen-pile rugs, manufaclocally known as nakhais, and the silk-embroidered phülkāris of the District have some artistic merit, but are not largely made. The lac work is inferior in technique to that of Dera Ismail Khān. Otherwise the District is destitute of any arts and manufactures, beyond the wares turned out to supply the everyday wants of the people. The clay used in unglazed pottery work at Bannu is of a superior quality, and some of the designs are quaint.

The chief exports are raw cotton, wool, gram, wheat, oil- Commerce. seeds, millet, and pulses; and the chief imports are sugar, piece-goods, indigo, ghi, wood, oil, iron, and tobacco. Bannu and Lakki are the only centres of commerce. The District has a surplus of agricultural produce, but depends on the Punjab for all manufactured articles.

No railway traverses the District, but the North-Western CommuniRailway has an out-station at Bannu for forwarding goods. cations. 'This town is connected with Dera Ismail Khān and Kohāt by a metalled road under the Military Works department, on which a line of tongas runs. The road up the Tochi 
is also metalled and possesses a tonga service. All other roads are unmetalled and are managed for the most part by the District board. Some of the roads are little better than sandy tracks; others, however, passing over firmer soil, are well defined, having a clayey surface, which is as hard as iron in dry weather but quickly becomes cut up after heavy rain. In the Bannu tahsil the roads are much intersected by irrigation channels and the courses of mountain streams. The most important are the road between Lakki and Naurang Sarai, and the frontier road, a mule track connecting the outposts on the border. There are $8 \mathrm{r}$ niles of metalled roads, all under the Military Works department, and 432 miles of unmetalled roads, of which 22 miles are Imperial, 91 Provincial, and 319 District.

Famine. Though the District was classed by the Irrigation Commission as secure from famine, the Marwat tahsil has recently been declared insecure. The area matured in the famine year 1899-1900 amounted to 77 per cent. of the average of the preceding five years.

District subdivisions and staff.

Civil justice and crime.

For administrative purposes the District is divided into the two tahsils of Bannu and Marwat, each under a tahsildār and naib-tahsildār. The Deputy-Commissioner is aided by an Assistant Commissioner, who holds the office of District Judge of Bannu and Dera Ismail Khān and also that of additional District Magistrate of Bannu, an Assistant Commissioner in charge of the border military police, and two Extra Assistant Commissioners, one of whom is in charge of the District treasury.

The Deputy-Commissioner, as District Magistrate, and the District Judge are both supervised in judicial matters by the Divisional Judge of the Derajāt Civil Division. The District Judge has one Munsif under him and one honorary Munsif, both at head-quarters. Violent crime used to be the chief characteristic of the District ; and murder, dacoity, highway robbery, and armed burglary were common, being carried out by the trans-border outlaws with the connivance of the leading men of the District. The military operations, however, against the Kābul Khel in November, 1902, which ended in the surrender of a large number of outlaws, had an excellent effect in tranquillizing the border, and crime has much diminished since that year. Rigorous enforcement of the preventive sections of the Frontier Crimes Regulation and Penal Code does much to preserve the security of the border. The inhabitants of Bannu are notoriously litigious, civil cases 
being more frequently instituted than in any other District on the frontier.

Our knowledge of the Bannu tahsil before annexation Land is of the vaguest description. The administrative unit, revenue political or fiscal, was the tappa, a block of villages whose tration. limits varied with the authority of its chief. Each tappa was a little independent state, warring with its neighbours from time to time and gaining or losing territory as the case might be. Force was the only method of revenue collection. When the tax-gatherer, whether Durrāni or Sikh, came with his army-and demanded tribute or revenue, he levied his demand on the chief man of the tappa, who proceeded to exact the sum required from such of the landholders as had not absconded, bribing the Saiyids to help by exempting them from contributions, and rewarding any one who paid a defaulter's share with that defaulter's land. For the first four years of British rule (1849-53) the revenue was collected by crop appraisement of each field. In $1852-3$ the first summary settlement was made on the average of these collections. This was revised, with a slight increase, in 1859 . The first demand was Rs. I,04,000 and the second Rs. I, I 3,000. Marwat under native rule was administered with a firmer hand. Under the Durrānis the Marwats paid a sum varying from Rs. I 2,000 to Rs. 40,000 as revenue or tribute, generally exacted at the point of the sword, while under the Nawāb of Mankerā or the Sikh rulers of Multān, both of them uncomfortably near neighbours, a full demand was exacted. Herbert Edwardes took over Marwat from Malik Fateh Khān Tiwānā, the Sikh lessee, in 1847 , and imposed a revenue of one-fourth of the gross produce in cash. This proportion was maintained by John Nicholson, who made the first summary settlement in 1853 . The demand was severe and large remissions were necessary. The second summary settlement was made on the same lines in $185^{8}$, and pressed unequally on the people, besides raising the total demand from $2 \cdot 2$ lakhs to nearly $2 \cdot 4$.

In 1872 the regular settlement of the District began. Although the actual assessments fell very much below the standard rate of half the net 'assets,' the new demand for the two tahsils was 3 lakhs (including cesses), while the revenue of the preceding year had been $2 \frac{3}{4}$ lakhs. The settlement has nowhere pressed severely, but suspensions have been found necessary in years of scarcity.

The latest revision began in 1903 , when it was found that 
the area under cultivation had increased since settlement by 43 per cent. and the irrigated area had doubled in Marwat and increased by 46 per cent. in Bannu, while prices have risen at least 25 per cent. After allowing for frontier remissions and considerations of general policy, it is estimated that the result will be an increase of Rs. $1,17,000$, or 47 per cent., of which Rs. I, ro,000 will be realized by Government. The rates of assessment at the last settlement were, per acre: 'dry' land, R. o-6-6 (maximum, annas 12 ; minimum, I anna); and 'wet' land, R. 0-9-6 (maxinum, 15 annas; minimum, 3 annas).

The total collections of revenue and of land revenue alone have been as follows, in thousands of rupees :-

\begin{tabular}{|c|c|c|c|c|}
\hline & $1880-1 *$ & $1890-1 *$ & $1900-1 *$ & $1903-4$. \\
\hline Land revenue & 3,06 & 4,37 & 4,07 & 2,55 \\
Total revenue & 4,79 & 5,77 & 7,15 & 2,59 \\
\hline
\end{tabular}

- These figures are for the old District, including the Miannwali and Isa Khel tahsils.

Local and municipal.

The District contains the two municipalities of Bannu (Edwardesäbād) and LAKKI. Local affairs elsewhere are managed by the District board. Its income in 1903-4 amounted to Rs. 36,300, chiefly derived from cesses, and its expenditure to Rs. 33,400 , public works forming the largest item.

Police and The regular police force consists of 410 of all ranks, jails. of whom $5^{8}$ are municipal police. The village watchmen number 334 . There are 8 police-stations, 2 outposts, and 7 road-posts. The border military police number $42 \mathrm{I}$, under a commandant who is an Assistant Commissioner. The force is directly under the orders of the Deputy-Commissioner, and is chiefly employed on the watch and ward of the border. The District jail at head-quarters can accommodate about 320 prisoners.

Education. Only $4 \cdot 1$ per cent. of the population were able to read and write in $190 \mathrm{r}$, the proportion being 7.3 among males, 0.2 among females. The Sikhs, with 53.7 per cent., are by far the most advanced community. Next come the Hindus (2r.8), while the Muhammadan cultivators are still markedly backward $(\mathrm{I} \cdot 5)$. The District is, however, making distinct progress in literacy, and even Wazīrs are sometimes met with who appreciate the value of reading and writing. The spread of female education, due mainly to the missionaries but partly also to the Arya Samãj, has been steady. 
The number of pupils under instruction was 650 in $1880-1$, $5,166^{1}$ in $1890-1,7,234^{1}$ in $1900-1$, and 8,447 in 1903-4. In the latest year the District possessed 3 secondary and 22 primary (public) schools, and 48 advanced and I 27 elementary (private) schools, with 55 girls in the public schools. The total expenditure on education was Rs. 25,000 , of which Government contributed Rs. 4,700, Local funds Rs. 5,100, municipal funds Rs. II, 200, and fees Rs. 3,900.

Besides the civil hospital at Bannu, the District possesses Hospitals one dispensary at Lakki, with 53 beds in all. In 1904 and disthe number of cases treated was $3 \mathrm{I}, 888$, including 687 inpatients, and r,330 operations were performed. The income was Rs. 7,400 , of which Local funds contributed Rs. 1,500 and municipal funds Rs. 5,900.

The number of successful vaccinations in 1903-4 amounted Vaccinato 10,424 , representing 45 per 1,000 of the population. Vac- ${ }^{\text {tion. }}$ cination is compulsory only in the town of Bannu.

[District Gazetteer, 1877 (under revision).]

Bannu Tahsil.-Tahsill of Bannu District, North-West Frontier Province, lying between $32^{\circ} 4 \mathrm{r}^{\prime}$ and $33^{\circ} 5^{\prime} \mathrm{N}$. and $70^{\circ} 22^{\prime}$ and $70^{\circ} 5^{\prime} \mathrm{E}$., with an area of 443 square miles. The tahsil is a green, fertile oasis, well wooded and watered, and much intersected by water channels. Its population in r9or was 130,444 , compared with 120,324 in $189 \mathrm{r}$. It contains the town of BANNU (population, 14,291), the tahsil and District head-quarters, and 217 villages. The land revenue and cesses amounted in $1903-4$ to Rs. $1,62,930$.

Marwat Tahsil. - Tahsil of Bannu District, North-West Frontier Province, lying between $32^{\circ} 16^{\prime}$ and $32^{\circ} 53^{\prime} \mathrm{N}$. and $70^{\circ} 23^{\prime}$ and $71^{\circ} 16^{\prime} \mathrm{E}$., with an area of 1,198 square miles. The whole tahsil is one large sandy plain. Its population in r 901 was 96,332 , compared with 84,145 in 1891 . It contains the town of LAKKI (population, 5,218), the head-quarters, and 145 villages. The land revenue and cesses amounted in $1903-4$ to Rs. $1,30,000$.

Bannu Town (or Edwardesābād).-Head-quarters of the District and tahsil of Bannu, North-West Frontier Province, situated in $33^{\circ} \mathrm{o}^{\prime} \mathrm{N}$. and $70^{\circ} 36^{\prime} \mathrm{E}$, near the north-west corner of the District, one mile south of the Kurram river, 79 south of Kohāt, and 89 north of Dera Ismail Khān. Population (1901), 14,29r, including cantonment and civil lines $(4,349)$. It was founded in 1848 by Lieutenant (afterwards

1 These figures are for the old District, including the Miānwāli and Isa Khel tahsils. 
Sir Herbert) Edwardes, who selected the site for political reasons. The fort, erected at the same time, bore the name of Dhulipgarh, in honour of the young Mahārāja of Lahore; and the bazar was also known as Dhulipnagar (Dalipnagar). A town gradually grew up around the bazar, and many Hindu traders removed hither from Bāzār Ahmad Khān, which had formed the commercial centre of the Bannu valley prior to annexation. The Church Missionary Society supports a small church and a high school founded in 1865 . The cantonment centres in the fort of Dhulipgarh. Its garrison consists of a mountain battery, a regiment of native cavalry, and two regiments of infantry. The municipality was constituted in 1867. The municipal receipts and expenditure during the ten years ending $1903-4$ averaged Rs. 46,000. In $1903-4$ the income was Rs. 47,000 , chiefly derived from octroi, and the expenditure was Rs. 55,000. The receipts and expenditure of cantonment funds during the ten years ending $1902-3$ averaged Rs. 4,200 and Rs. 3,700. The profuse irrigation and insufficient drainage of the surrounding fields render Bannu an unhealthy station. The town has a considerable trade, embracing the whole traffic in local produce of the Bannu valley. The nearest railway station is at Kohāt on the KhushālgarhThal branch of the North-Western Railway, 79 miles distant by road. A weekly fair collects an average number of 8,000 buyers and sellers. The chief articles of trade are cloth, live-stock, wool, cotton, tobacco, and grain. Bannu possesses a dispensary and two high schools, a public library, and a town-hall known as the Nicholson Memorial.

Lakki. - Head-quarters of the Marwat tahsil, Bannu District, North-West Frontier Province, situated in $32^{\circ} 36^{\prime} \mathrm{N}$. and $70^{\circ} 5^{\prime}$ E. Population (1901), 5,218. In 1844 Fateh Khān Tiwanna, the revenue collector of the Sikh government, built and garrisoned a fort in the heart of Marwat which he called Ihsanpur. A town grew up under its walls and became the capital of Marwat until I864, when the site was abandoned and the inhabitants removed to Lakki on the right bank of the Gambila. The municipality was constituted in 1874 . The income during the ten years ending $1902-3$ averaged Rs. 5, 200, and the expenditure Rs. 5,300. In 1903-4 the income was Rs. 5,500, chiefly derived from octroi, and the expenditure was Rs. 5, 100. The town has a dispensary and a vernacular middle school maintained by the municipality.

Akra (Akarah).-Ancient site in Bannu District, NorthWest Frontier Province, situated in $33^{\circ} \mathrm{N}$. and $70^{\circ} 36^{\prime}$ E., near 
Bannu town. It is said to have been the seat of government of Rustam, son of Zāl-i-zar, or 'Zāl of the golden locks,' and a daughter of the Kābul Shāh. Rustam's sister, Bānu, held it as her apanage, whence the adjacent territory is said to have acquired the name of Bānu. Engraved gems of Greek or West Asian provenance, one in the late Mycenaean style, have been found on the site.

[Furtwängler's Antike Gemmen, ii, pp. 27, 59; and iii, 22, 23 , and 25.]

Dera Ismail Khān District.-Southernmost District of Bounthe North-West Frontier Province, lying between $31^{\circ} 15^{\prime}$ and daries, con$32^{\circ} 32^{\prime} \mathrm{N}$. and $70^{\circ} 5^{\prime}$ and $71^{\circ} 22^{\prime}$ E., with an area of 3,780 and hill square miles. The District forms an irregular cone, pointing and river south, its base or north being formed by the crest of the Bhittanni and Marwat ranges, its eastern border by the river Indus, and its western by the Shirāni or Sulaimān Hills. Its southern extremity is barely 20 miles in breadth, and adjoins the District of Dera Ghāzi Khān in the Punjab. The Khisor range, also called the Ratta Koh (or 'red mountain'), penetrates its north-eastern corner for some miles, intervening between the Indus and the eastern end of the Bhittanni hills, which here turn to the north-east and run parallel to it. The rest of the District is divided between the $k a c h i$ or Indus riverain and the damman, a great plain stretching between it and the hills. The dāman, or 'skirt of the hills,' is a term applicable in its strict sense only to the tract inhabited by Pathān tribes stretching immediately beneath the hills, while the rest of the plain up to the kachi, which is inhabited by Jats, is the makkalwad; but the latter term is now disused, and the whole area from the hills to the kachi is called the dâman. It is a level plain without trees and grass, and except where cultivated is unbroken save by a few scattered bushes. In places even these do not grow, the soil being a firm, hard clay into which water does not sink readily, though after continuous rain it is turned into a soft, tenacious mud, and the country becomes impassable. Such soil is locally called pat. The damman is intersected by numerous torrents, which flow from the eastern slopes of the Sulaimān range and form deep fissures in its level expanse. For the greater part of the year these torrents are almost dry, carrying but slight streams of clear water which disappear long before they reach the Indus, but after rain they become roaring torrents bringing down water discoloured by heavy silt. But for these streams the daman would be a desert, but by arresting their flow and spreading them over the barren 
levels, the cultivators transform the whole face of the country; and the richly cultivated fields, with their embankments planted with tamarisk trees lying against the background of blue hills, give the tract in places quite a picturesque look. The kachi or Indus riverain is a narrow strip of alluvial land beneath the old bank of the Indus, partly overgrown with tamarisk and poplar jungle and tall saccharum grass.

Geology'. The District has only been visited occasionally by geologists. The greater portion of its surface is occupied by the recent and post-Tertiary gravels and alluvium belonging to the Indus drainage area. On its western boundary in the Shirãni and Sulaimān Hills, the main formation runs north and south in one great anticlinal arch or fold with minor secondary folding eastwards near the plains. The lowest formation seen along the main axis of the range is probably of Jurassic age, and is a thick, massive limestone. Above it come the so-called Belemnite shales of neocomian (?) age. Above these lie immense thicknesses of eocene Nummulitic limestone, sandstone, and shales, the whole having a resemblance to the Baluchistän and Sind rocks rather than to those of the country farther north. Over these are the Siwālik sandstones, shales, and conglomerates of younger Tertiary age, dipping regularly under the recent deposits of the Indus valley. On the northern borders of the District the strike bends sharply round to the south-east and east-north-east, following the curve of the Bhittanni, Marwat, and Khisor ranges. Here besides Siwãlik conglomerate and sandstone, the Marwat and Khisor ranges show the lower Permo-carboniferous boulder-bed of glacial origin, containing boulders of igneous rock derived by ice transport from the Mallāni series of Rãjputāna. Above the boulder-bed come 500 feet of Upper Permian, grey magnesian and white limestone, with some sandstone and earthy beds containing Productus limestone fossils like those to the east of the Indus; also thin-bedded ceratite limestone of the Trias, and above that 1,500 feet of Jurassic sandstones and limestones, passing into Cretaceous at the top of the Sheikh Budin hill in the Marwat range. A thin band of Nummulitic limestone underlies the Siwãlik sandstones along the north-west slopes of the Khisor range.

${ }^{1}$ C. L. Griesbach, 'Geology of the Takht-i-Sulaiman Range,' Records, Geological Survey of India, vol. xvii, part iv; and T. D. La Tonche, 'Geology of the Sherani Hills,' Records, Geological Survey of India, vol. xxvi, part iii ; A. B. Wynne, 'Trans-Indus Salt Range,' Memoirs, Geological Survey of India, vol. xvii, part iii. 
The vegetation of the District is composed chiefly of scrub Botany. jungle with a secondary element of trees and shrubs. The more common plants are Flacourtia sapida, F. sepiaria, several species of Grewia, Zizyphus nummularia, Acacia Jacquemontii, A. leucophloea, Alhagi camelorum, Crotalaria Burhia, Prosopis spicigera, several species of Tamarix, Nerium odorum, Rhazia stricta, Calotropis procera, Periploca aphylla, Tecoma undulata, Lycium europaeum, Withania coagulans, W. somnifera, Nannorhops Ritchieana, Fagonia Tribulus, Peganum Harmala, Calligonum polygonoides, Polygonum aviculare, P. plebejum, Rumex vésicarius, Chrozophora plicata, and species of Aristida, Anthistiria, Cenchrus, and Pennisetum.

Märkhor and uriall are found in the hills, and there are Fauna. a few leopards round Sheikh Budinn, and wolves and hyenas are occasionally seen. Otters are common on the banks of the Indus. Among birds the great bustard is rare, but the lesser bustard is common on the pat. One or two kinds of eagle are seen in the hills, and the lämmergeyer is fairly common on Sheikh Budin.

The climate is drier than that of either Bannu or Dera Climate Ghāzi Khān, and the maximum temperature seems to have and tem. increased of late years. Thirty years ago the thermometer never rose above $110^{\circ}$, while the hot season never passes now without $116^{\circ}$ or even more being registered. The winter is cold and bracing. The frost is so severe that mango trees cannot be grown in the open without a covering. The District on the whole is fairly healthy, though the autumn fever sometimes takes a malignant form.

The annual rainfall is slight, averaging ro inches at head- Rainfall. quarters. The greatest fall of late years was 24 inches in $1897-8$ at Sheikh Budin, while the least recorded during any one year was 0.8 inch at Tānk in $1888-9$.

The earliest traditions current in this remote quarter refer History. to its colonization by immigrants from the south, who found the country entirely unoccupied. The Baluchi settlers, under Malik Sohrāb, arrived in the District towards the end of the fifteenth century. His two sons, Ismail Khān and Fateh Khān, founded the towns which still bear their names. The Hot family, as this Baluchi dynasty was termed, in contradis. tinction to the Mirāni house of Dera Ghāzi Khān, held sway over the Upper Derajāt for 300 years, with practical independence, until reduced to vassalage by Ahmad Shāh Durrāni about $17500^{\circ}$ In 1794 Shāh Zamān, then occupying the Durrāni throne, conferred the government of this dependency, together 
with the title of Nawãb, upon Muhammad Khān, an Afghãn of the Sadozai tribe, related to the famous governors of Multann. Muhammad Khān became master of the whole District together with a considerable tract to the east of the Indus. $\mathrm{He}$ died in $18 \times 5$, after a prosperous reign of twenty-two years. His grandson, Sher Muhammad Khān, succeeded to the principality, under the guardianship of his father, the late Nawāb's son-in-law. He was soon dispossessed of his territories east of the Indus by Ranjit Singh, and retired across the river to Dera Ismail Khān, retaining his dominions in the Derajāt for fifteen years, subject to a quit-rent to the Sikhs, but otherwise holding the position of a semi-independent prince. His tribute, however, fell into arrears; and in 1836 , Nao Nihāl Singh crossed the Indus at the head of a Sikh army, and annexed the District to the territories of Lahore. The Nawāb received for his maintenance an assignment of revenue, a portion of which is still retained by his descendants, together with their ancestral title.

Under Sikh rule, the Upper Derajāt was farmed out to the Dīwān Lakhi Mal, from whom it passed to his son, Daulat Rai. British influence first made itself felt in 1847 , when Lieutenant (afterwards Sir Herbert) Edwardes, being dispatched to the frontier as the representative of the Lahore Darbār, effected a summary assessment of the land revenue. In the succeeding year, levies from Dera Ismail Khān and Bannu followed Edwardes to Multān, and served loyally throughout the war that ended in the annexation of the Punjab. The District then passed quietly under British rule. On the first subdivision of the Province Dera Ismail Khān became the head-quarters of a District, which also originally included Bannu. In r86 I Bannu was entrusted to a separate officer, and the southern half of Leiah District, consisting of the Bhakkar and Leiah tahsils of the present Miānwāli District in the Punjab, was incorporated with Dera Ismail Khān. In r857 some traces of a mutinous spirit appeared among the troops in garrison at the head-quarters station; but the promptitude and vigour of the Deputy-Commissioner, Captain Coxe, loyally aided by a hasty levy of local horse, averted the danger without serious difficulty. In 1870 the District attracted for a time a melancholy notoriety through the death of Sir Henry Durand, Lieutenant-Governor of the Punjab, who was crushed against an arch and precipitated from his elephant as he entered a gateway in the town of Tãnk. His remains were interred at Dera Ismail Khān. The Bhakkar and Leiah tahsils and thirty-two villages of the Kulāchi tahsil 
were detached from the District on the formation of the North-West Frontier Province in r 901 .

Dera Ismail Khān District contains 3 towns and $4 \circ 9$ villages. The The population at the last three enumerations was: (I88r) people. 203,74I, (r 89r) 229,844, and (I901) 247,857. During the last decade it increased by 8 per cent., the increase being greatest in the Tãnk tahsīl and least in Kulāchi. The District is divided into three tahsils, the head-quarters of which are at the places from which each is named. Statistics for r gor are shown below :-

\begin{tabular}{|c|c|c|c|c|c|c|c|}
\hline \multirow{2}{*}{ Tahsil. } & \multirow{2}{*}{ 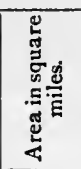 } & \multicolumn{2}{|c|}{ Number of } & \multirow{2}{*}{ 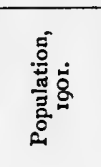 } & \multirow{2}{*}{ 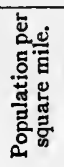 } & \multirow{2}{*}{ 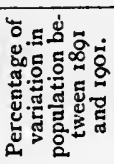 } & \multirow{2}{*}{  } \\
\hline & & $\stackrel{d}{\tilde{E}}$ & 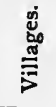 & & & & \\
\hline $\begin{array}{l}\text { Dera Ismail } \\
\text { Kulāchi } \\
\text { Tāuk. }\end{array}$ & $\begin{array}{r}1,699 \\
1,509 \\
57^{2}\end{array}$ & $\begin{array}{l}1 \\
1 \\
1\end{array}$ & $\begin{array}{r}250 \\
81 \\
78\end{array}$ & $\begin{array}{r}144 \\
55 \\
48\end{array}$ & $\begin{array}{l}85 \\
36 \\
85\end{array}$ & $\begin{array}{r}+\quad 7.9 \\
+\quad 5.3 \\
+10.8\end{array}$ & $\begin{array}{l}7,630 \\
2,116 \\
2,368\end{array}$ \\
\hline Total & 3,780 & 3 & 409 & 247,857 & 66 & $+7 \cdot 8$ & $12, I_{4}$ \\
\hline
\end{tabular}

The towns are the municipalities of Dera Ismail Khān, the administrative head-quarters of the District, and KULĀCHI, and the 'notified area' of TĀNK. Muhammadans number 2 I 3,816 , or more than 87 per cent. of the total; Hindus 29,434 ; and Sikhs (including the garrison) 4,362 . The density is very low. The Indus valley supports a considerable population, but the damman is very thinly inhabited. Along the foot of the hills to the west, Pashtū is spoken, elsewhere Jatkī, a mixture of Punjābi and Sindī.

Pathāns number 73,000 , or less than 30 per cent. of the Castes and population, an unusually small proportion in a frontier District: occupathey are returned under 26 subdivisions, no one of which preponderates as do various clans of the Utmānzai and Ahmadzai in Bannu: the Marwats $(8,000)$ are the largest group, while other well-known names are the Sulaimān Khel $(5, \infty 00)$ and the Bhittannis $(6,000)$. The large number of Baluchis $(2 \mathrm{I}, 000)$ is significant of the remoteness of Dera Ismail Khān from Afghānistān proper. Jats, who cluster in the Indus valley, number 58,000 , practically all Muhammadans. Saiyids return 5,000 and Awãns 6,000; Khokhars, Rājputs, and Arains 3,000 each. Of the commercial and money-lending classes, only the Aroras, who number 23,000 , appear in strength, the Khattris returning 2,000; Shaikhs, who mostly live by trade, number 5,000 . Of the artisan classes, the Mochis (shoemakers and 
leather-workers, 5,000), Tarkhāns (carpenters, 4,000), and Kumhārs (potters, 3,000), are the most important ; and of the menials the Chūhrās and Kutānas (sweepers, 6,000), Machhis (fishermen, bakers, and water-carriers, 4,000), and Chhimbas and Dhobis (washermen, 4,000). The Mallāhs (boatmen, 3,000 ) and Kaneras (a fishing tribe, 2,000) are also worth mention. Agriculture supports 50 per cent. of the population.

Christian There were 68 Christians in r9or. The Church Missionary missions. Society opened a branch at Dera Ismail Khān in 186r. The Church of England Zanāna Mission maintains a dispensary in Dera Ismail Khān town. The Church Missionary Society has hospitals at Dera and Tānk, and also maintains a high school at Dera.

General The District is naturally divided into five tracts, each agricultural conditions. peculiar in the quality of its soil and the nature of its cultivation. In the daman the soil is a hard clay, and cultivation is carried on in embanked fields, largely assisted by water from streams, hill torrents, or from the surface drainage. The Paniāli tract, including the Largi valley and the Paniāli Tal, has a sandy soil with cultivation depending chiefly on rain. In the hilly lands of the Khisor, Nila Koh, and Bhittanni ranges the cultivation depends entirely on rain. The kachi or alluvial land of the Indus is cultivated either by means of wells or with the aid of the river floods. The fifth tract.is known as the Rug-Pahārpur tract and in parts resembles the kachi, but is mainly dependent for irrigation on wells and canals, and the drainage from the Khisor hills. The spring harvest (which in $190^{-4} 4$ accounted for 61 per cent. of the area harvested) is sown from the middle of September to the middle of January; the autumn harvest chiefly in June, July, and August.

Chief agri- The District is held almost entirely on pattidāri and bhaiya-


and princi-miles, and lands leased from Government about 24.5 square pal crops. miles. The staple crops are wheat and bajjra, covering 176 and 143 square miles respectively in $1903-4$, or 34 and 28 per cent. of the net area cultivated. Gram and jowēar (7 square miles each) are grown to a much smaller extent. The table on the next page gives the main agricultural statistics in 1903-4, areas being in square miles.

Improve- The area under cultivation increased only from 754 square ments in agricultural practice. miles in $1877-8$ to 787 square miles in $1903-4$, showing that cultivation is practically stationary. Advances under the Land Improvement Loans Act are but little sought after; during the five years ending 1902-3, only Rs. 5,790 was 
advanced under this head; when taken they are generally applied to the construction of embankments. During the same period Rs. $1,03,505$ was advanced for the purchase of bullocks and seed. The sums advanced under the Acts in 1903-4 were respectively Rs. 460 and Rs. 21,000 .

\begin{tabular}{|c|c|c|c|c|c|}
\hline Tahsil. & Total. & Cultivated. & Irrigated. & $\begin{array}{c}\text { Cultivable } \\
\text { waste. }\end{array}$ & $\begin{array}{l}\text { Area not } \\
\text { available for } \\
\text { cultivation. }\end{array}$ \\
\hline $\begin{array}{l}\text { Dera Ismail Khān } \\
\text { Kulāchi : } \\
\text { Tānk :- }\end{array}$ & $\begin{array}{r}1,699 \\
1,509 \\
57^{2}\end{array}$ & $\begin{array}{l}416 \\
200 \\
171\end{array}$ & $\begin{array}{r}109 \\
21 \\
103\end{array}$ & $\begin{array}{l}790 \\
717 \\
203\end{array}$ & $\begin{array}{l}49 \\
59 \\
20\end{array}$ \\
\hline Total & 3,780 & $7^{87}$ & 233 & 1,710 & 128 \\
\hline
\end{tabular}

The District is not adapted to cattle-breeding owing to the Cattle, deficiency of pasture, and the local breed is small. Buffaloes, ponies, however, are largely kept in the Indus lowlands, where their milk, and the ghi made from it, play an important part in the economy of the villagers. Camels are extensively bred in the dàman, and large numbers of Powinda camels, which are superior to those bred in the District, graze in it during the cold season. A good many sheep of the fat-tailed breed are also grazed here. The District possesses many horses, which are of a fair breed though small. The Civil Veterinary department maintains two horse and one donkey stallion, and a pony stallion is kept by the District board. A veterinary hospital has recently been opened at Dera Ismail Khān.

Of the total cultivated area in $1903-4,135.5$ square miles, Irrigation. or 4 per cent., were classed as irrigated. Of this area, $\mathbf{I} \cdot \mathbf{2}$ square miles were irrigated by wells and 124.3 square miles by canals. In addition, $97 \cdot 1$ square miles, or 13 per cent. of the cultivated area, were subject to inundation. Irrigation from wells is confined to the kachi tract bordering the Indus. In 1903-4, 833 masonry wells were in use, all worked with Persian wheels by cattle, besides 75 unbricked and lever wells. The canals are all private property, and are chiefly cuts which divert the water of the streams and torrents upon the fields. An inundation canal from the Indus to irrigate more than 30,000 acres has lately been begun, which is estimated to cost 7 lakhs.

The forests consist of 6 square miles of military 'reserved' Forests. forest, and 137 square miles of unclassed forests under the Deputy-Commissioner, from which the revenue in $1903^{-4}$ was Rs. 5,440. The District is very poorly wooded, the nearest 
approach to true forest being the tamarisk jungles of the Indus riverain.

Mineral. The only important mineral product is limestone, which exists abundantly, but is little utilized conmercially. Oil is found at Mughalkot, where it issues from the sandstones at the base of the Nummulitic series. The lower hills contain much gypsum and alum; naphtha and saltpetre occur in the Sheikh Budin range.

Arts and The manufactures of the District are not important. Coarse manufactures.

Commerce and

trade. cotton cloth is woven in many villages and in Dera Ismail Khān, where lungis of creditable workmanship are also made. Turned and lacquered wood-work of remarkable excellence of design is made at Dera Ismail Khān and Pahārpur.

Commercially the District is only of importance as lying across the routes of the trade carried on between India and Khorāsān by travelling Powinda merchants. The Powinda caravans for the most part enter it by the Gomal Pass in October, and, passing into India, return in March and April. The principal articles carried are silk, charas, gold and silver thread, and furs from Bokhāra, fruits and wool from Ghazni and Kandahār, and madder, wool, ghï, tobacco, and asafoetida from Ghazni; the return trade consisting of indigo, cotton piece-goods, metals, sugar, salt, shoes, and leather. This trade, however, does not affect the District directly, as the Powindas very seldom unpack any of their wares within it. The District imports piece-goods, hides, salt, and metals, and exports wheat and great millet, the export trade passing down the Indus to Multān, Sukkur, and Karāchi. The chief centres of local trade are Dera Ismail Khān, Tānk, and Kulāchi.

Communi- The Indus and its main branches are navigable, and carry a cations. good deal of traffic. The river is crossed at Dera Ismail Khān by a steam ferry in the hot season, and a bridge of boats in the winter, and by nine other ferries. The station of Daryã Khān on the North-Western Railway lies in Miānwāli District on the east bank of the Indus, opposite Dera Ismail Khān. There are 546 miles of roads in the District, of which $r 09$ miles are metalled.

Famine. The District was classed by the Irrigation Commission of 1903 as one of those in which the normal rainfall is so deficient that cultivation is almost impossible without irrigation, and which therefore are not considered as liable to famine. The area of crops that matured in the famine year 1899-1900 amounted to 78 per cent. of the normal. 
The Deputy-Commissioner is aided by an assistant and three District Extra Assistant Commissioners. One Assistant Commissioner subdivicommands the border military police, and an extra Assistant staff. Commissioner is in charge of the Tānk subdivision, while another Extra Assistant Commissioner holds charge of the District treasury. Each of the three tahsīls is under a tahsildār and naib-tahsîldār, and the Tānk tahsīl forms a subdivision.

Civil judicial work is disposed of by a District Judge, who is Civil jusalso District Judge of Bannu, where the court is held. Both tice and he and the District Magistrate are supervised by the Divisional and Sessions Judge of the Derajāt Civil Division. A Munsif is stationed at head-quarters. There is little violent crime, but cattle-stealing, mostly unreported, is an almost universal practice, especially in the kachi tract.

The revenue history of the several tahsils differs consider- Land ably. Previous to annexation Tānk formed a separate go- revenue. vernment under Nawāb Sarwar Khān, paying $1 \frac{1}{4}$ to $1 \frac{1}{2}$ lakhs revenue. Herbert Edwardes leased the tahsill to the Nawāb for five years at an annual rent of one lakh. The Dera Ismail Khān and part of the Kulāchi tahsìls were divided into ten blocks (talukas) for revenue purposes, in each of which one of the leading men superintended the collections. In 1848 Edwardes himself assessed all of the Kulāchi tahsill which was not assigned, though very roughly. Summary settlements were made in $185^{\circ}-1$ in the Dera Ismail Khān and Kulāchi tahsīls, and in r 853-4 in Tānk, as the Nawāb was heavily in arrears and consequently had been deprived of his lease. All three tahsils (except the Kulāchi taluka) were again settled in 1857 for seven years. The earlier summary settlement realized 2.4 lakhs, and that from 1857 to 1862 realized 2.5 lakhs, rising to 2.7 lakhs. Between 1873 and 1879 a regular settlement was made, and fluctuating assessments were introduced below the hills and in the lands liable to floods. The demand amounted to three lakhs, of which $\mathrm{r} \frac{1}{4}$ lakhs was fluctuating revenue. A revised assessment began in $x 898$. It is intended to extend the fluctuating system of land revenue to the greater part of the District. The new settlement is not yet altogether complete; but the demand under the head of fixed land revenue has been reduced to Rs. 35,800 , while the greatest amount of land revenue payable to Government in a favourable year will be 2.88 lakhs, of which rather more than I lakh is assigned. Fixed rates at the last settlement fluctuated between Rs. 2-3-0 and 4 annas per acre on 'wet' land. Crop rates varied from R. I to 8 annas. 
The following table shows total collections of revenue and those of land revenue alone, in thousands of rupees :-

Local and municipal.

\begin{tabular}{|cc|c|c|c|c|}
\hline & $1880-1^{*}$ & $1890-1^{*}$ & $1900-1$. & $1903-4 \cdot$ \\
\hline Land revenue & $\cdot$ & 1,75 & 4,64 & 2,05 & 1,98 \\
Total revenue & $\cdot$ & 5,93 & 6,33 & $2,4^{2}$ & 2,50 \\
\hline
\end{tabular}

- These figures are for the old District, including the Bhakkar and Leiah eaksils.

The District contains two municipalities, Dera IsmaIl KHĀN and KULĀCH1, and one 'notified area,' 'TĀNK. Outside these areas, local affairs are managed by a District board. Its income, mainly derived from local rates, amounted in 1903-4 to Rs. 43,400 . The expenditure in the same year was Rs. $4 \mathrm{I}, 400$, the mail-cart service forming the largest item.

Police and The regular police force consists of 483 of all ranks, of whom jails. 79 are municipal police, 41 mounted men, and $\mathrm{r}_{3}$ trackers. Village trackers are also frequently employed. There are 8 police-stations, 3 outposts, and 4 road-posts. The border military police number 607 of all ranks, including I 25 mounted men. They are commanded by an Assistant Commissioner, directly under the orders of the Deputy-Commissioner, and occupy fourteen posts, of which six are actually in the Shirāni country, a political apanage of the District, though administratively distinct from it. The jail at head-quarters has accommodation for 497 prisoners.

Education. The average of literacy is high for the North-West Frontier Province, on account of the large Hindu element in the population. In I90I, 9.3 per cent. males and I.5 per cent. females were returned as able to read and write, the proportion of literate persons of both sexes being 48.6 among Sikhs, 26.6 among Hindus, and 1.5 among Muhammadans, who form the agricultural population.

The number of pupils under instruction was 893 in $1880-1$, 3,244 in $1890-1$, and 8,943 in 1903-4. In the latest year there were 4 secondary and 25 primary (public) schools, and 8 advanced and 99 elementary (private) schools, with 289 girls in the public and $49 \mathrm{I}$ in the private schools. Dera Ismail Khãn town possesses two Anglo-vernacular high schools. Of the indigenous schools, the Hindu girls' school at Dera Ismail Khăn deserves notice. It was opened in $188 \mathrm{I}-2$, and is maintained by the municipality. The total expenditure on education in 1903-4 was Rs. 23,400, of which Rs. 6,500 was contributed by the District funds, Rs. 7,400 by the municipalities, and Rs. 6,600 by fees.

Hospitals Besides the Dera Ismail Khān civil hospital, the District 
contains five outlying dispensaries. In 1904 the number of and discases treated was 66,633 , including $9 \circ 5$ in-patients, and 3,088 pensaries. operations were performed. The income was Rs. 17,600 , the greater part of which came from Local funds.

The number of successful vaccinations in $1903-4$ was 8,928 , Vaccinarepresenting 33 per $\mathrm{r}, 000$ of the population.

[District Gazetteer, 1878 (under revision).]

Dera Ismail Khān Tahsī1.-Head-quarters tahsīl of Dera Ismail Khān District, North-West Frontier Province, lying between $31^{\circ} 18^{\prime}$ and $32^{\circ} 32^{\prime} \mathrm{N}$. and $70^{\circ} 31^{\prime}$ and $71^{\circ} 22^{\prime}$ E., with an area of $-1,699$ square miles. It consists of a bare plain, generally barren except for a few tamarisks and acacias, but covered with crops in favourable seasons. Water is so scarce that in the hot season the people often have to desert their villages and camp with their cattle by the Indus. The population in I 90 I was 144,337 , compared with 133,809 in I 891 . The headquarters are at DeRA IsMaIL $\mathrm{K}_{\mathrm{HA}} \overline{\mathrm{A}}$ (population, $3 \mathbf{1}, 737$ ), and the tahsil also contains 250 villages. The land revenue and cesses amounted in 1903-4 to Rs. 87,860 .

Kulāchi Tahsīl.-Western tahsīl of Dera Ismail Khān District, North-West Frontier Province, consisting of the country immediately below the Sulaimān mountains, between $3 \mathrm{I}^{\circ}$ $15^{\prime}$ and $32^{\circ} 17^{\prime} \mathrm{N}$. and $70^{\circ} \mathrm{I} \mathrm{I}^{\prime}$ and $70^{\circ} 42^{\prime} \mathrm{E}$., with an area of $x, 5 \circ 9$ square miles. In appearance the tract bears a generic resemblance to the Dera Ismail Khān tahsīl, except for the stony plain and the line of barren and unsightly hills which form its western border. The plain is much cleft by deep channels which carry off the rain-water from the hills, and these are utilized for irrigation with great skill. The population in rgor was 55,053 , compared with 52,270 in 1891 . The head-quarters are at KuLĀCHI (population, 9, I25), and the tahsil also contains $8 \mathrm{r}$ villages. The land revenue and cesses amounted in $1903-4$ to Rs. 96,000 .

Tānk Tahsil.-Subdivision and tahsīl of Dera Ismail Khān District, North-West Frontier Province, lying between $32^{\circ}$ and $32^{\circ} 30^{\prime} \mathrm{N}$. and $70^{\circ} 4^{\prime}$ and $70^{\circ} 43^{\prime}$ E., with an area of 572 square miles. It is bounded on the west by Wazīistān, and occupies the north-western corner of the District, at the foot of the Sulaimān Hills. The country long lay uninhabited, there being little to tempt any settlers in so barren a tract; but it was finally occupied by Pathān tribes from the western hills. The tahsil was formerly a semi-independent State, and its Nawābs belonged to the Kati Khel section of the Daulat Khel clan, the most powerful of the 
original settlers, who gradually expelled all the rest. The last Nawāb, Shāh Nawã Khān, who died in $\mathbf{r}^{882}$, is said to have been twentieth in descent from Daulat Khān, who gave his name to the tribe. His family first assumed the tribal headship in the person of Katāl Khān, great-grandfather of Shāh Nawāz. His son, Sarwar Khān, a remarkable man, devoted himself throughout a long reign to the amelioration of his territory and his tribesmen. Under his'sway the Daulat Khel changed from a pastoral to an agricultural people, and they still revere his memory, making his acts and laws the standard of excellence in government. Sarwar Khān towards the end of his life found it necessary to tender his submission to the Sikhs, after their occupation of Dera Ismail Khān, and his tribute was fixed at Rs. I 2,000 ; but before his death (1836) it was gradually enhanced, as the Sikh power consolidated itself, to Rs. 40,000 per annum. Sarwar Khān was succeeded by his son Aladād Khān; and at the same time Nao Nihāl Singh, who was then in Bannu, raised the demand to a lakk. Aladād Khān was unable to meet the demand and fled to the hills, where he found a refuge among the Mahsūds. Tānk was then given in jāgir to Nao Nihāl Singh ; but Aladād kept up such a constant guerilla warfare from the hills that the Sikh grantee at last threw up his possession in disgust. Malik Fateh Khān Tiwānā then for a time seized Tānk, but he was ousted by Daulat Rai, son of Diwwān Lakhi Mal, the Sikh governor; and it was made over to three dependants of the Nawābs of Dera, Shāh Nawāz Khān, the son of Aladād (who had died meanwhile), being left a beggar. In 1846 , however, the exiled chief attached himself to Lieutenant (afterwards Sir Herbert) Edwardes, who procured his appointment by the Lahore Darbär to the governorship of Tānk. After the annexation of the Punjab, the British Government confirmed Shāh Nawāz Khān in his post as governor; and he thenceforward enjoyed a semi-independent position, retaining a portion of the revenues, and entrusted with the entire internal administration, as well as with the protection of the border. The results, however, proved unsatisfactory, as regards both the peace of the frontier and the conduct of the administration. A scheme was accordingly introduced for remodelling the relations of the State. The Nawāb's income was increased, but he was deprived of all administrative powers, retaining only those of an honorary magistrate. Tānk thus became an ordinary tahsil of Dera Ismail Khān District. It consists of a naturally dry and uninviting plain, intersected by ravines and low ranges of stony hills which here and there traverse the 
plain. By assiduous cultivation, however, it has acquired an aspect of prosperity and greenness which distinguishes it strongly from the neighbouring tahsīl of Kulāchi. The population in rgor was 48,467 , compared with 43,725 in 1891 . The head-quarters are at TĀNK (population, 4,402), and the tahsil also contains 78 villages. The land revenue and cesses amounted in $1903-4$ to Rs. 67,000 .

Dera Ismail Khān Town.--Head-quarters of the District and tahsill of Dera Ismail Khān, North-West Frontier Province, situated in $31^{\circ} 49^{\prime} \mathrm{N}$. and $70^{\circ} 55^{\prime} \mathrm{E}$. Population (r9or), 31,737 , of whom I 8,662 were Muhammadans, $\mathrm{r}$ I, 486 Hindus, and 1,420 Sikhs. Of the total, 3,450 live in the cantonment. The town lies $4 \frac{1}{2}$ miles west of the right bank of the Indus, 200 miles west of Lahore, and 120 miles north-west of Multān. It was founded towards the end of the fifteenth century by Ismail Khān, a son of the Baloch adventurer Malik Sohrāb, who called the town after his own name. The original town was swept away by a flood in 1823 , and the existing buildings are all of quite modern construction. It contains two bazars, the Hindu and Muhammadan population living in separate quarters. The town stands on a level plain, with a slight fall to the river, but is badly drained. It is surrounded by a thin mud wall, with nine gates, enclosing an area of about 500 acres. The cantonment, which lies south-east of the town, has an area of $4 \frac{3}{4}$ square miles, excluding the portion known as Fort Akālgarh on the north-west side. The civil lines are to the south. The Derajāt Brigade has its winter head-quarters at Dera Ismail Khān, and the garrison consists of a mountain battery, a regiment of native cavalry, and three regiments of native infantry. Detachments from these regiments help to garrison the outposts of Drazinda, Jandola, and Jatta. The municipality was constituted in 1867 . The income during the ten years ending 1902-3 averaged Rs. 55,000, and the expenditure Rs. 53,000. The income and expenditure in $1903^{-4}$ were Rs. 55,500 and Rs. 55,800, respectively. The chief source of income was octroi (Rs. 48,000); and the chief items of expenditure were conservancy (Rs. 8,785), education (Rs. 7,246), hospitals and dispensaries (Rs. 6,302), public safety (Rs. 7,733), public works (Rs. 2, r43), and administration (Rs. 5,546). The receipts and expenditure of cantonment funds during the ten years ending 1902-3 averaged Rs. 2,700 and Rs. 2,800, respectively.

The local trade of Dera Ismail Khān is of second-rate importance, but some foreign traffic with Khorāsān passes 
through it. Powinda caravans of Afghān merchants traverse the town twice a year on their road to and from India; and, with the increasing security of the Gomal route, these caravans are yearly swelling in numbers. The chief imports are English and native piece-goods, hides, salt, and fancy wares; and the exports, grain, wood, and ghi. The local manufactures are lungis and lacquered wood-work. The town possesses a civil hospital, and its chief educational institutions are two aided Anglo-vernacular high schools, one maintained by the Church Missionary Society and the other by the Bharatri Sabha, and an Anglo-vernacular middle school maintained by the municipality.

Kāfirkot.-Ruins in Dera Ismail Khān District, NorthWest Frontier Province, situated in $32^{\circ} 30^{\prime} \mathrm{N}$. and $7 \mathrm{x}^{\circ} 2 \mathrm{x}^{\prime} \mathrm{E}$. The site is also known as Til Kāfirkot or Rājā Sir-kot, and lies a few miles south of the point.where the Kurram river joins the Indus, upon a spur of the Khisor hills. The remains consist of extensive lines of bastioned walls built of solid masonry, enclosing an area filled with the débris of ancient dwellings. The remains of four small Hindu temples are relatively well preserved, and their outer faces are decorated with elaborate carvings of stone. For some details see A. Cunningham, Archaeological Survey Reports, vol. xiv, 26, 254, and Dr. Stein's Archaeological Survey Report of the NorthWest Frontier Province and Baluchistān (1903-5). A similar ruin of the same name exists at Bilot, about 30 miles due south.

Kulāchi Town.-Head-quarters of the tahsil of the same name in Dera Ismail Khān District, North-West Frontier Province, situated in $31^{\circ} 56^{\prime} \mathrm{N}$. and $70^{\circ} 28^{\prime} \mathrm{E}$., on the north bank of the Luni torrent, 27 miles west of Dera Ismail Khān. Population ( 1901 ), 9, 125 . It is rather an aggregation of sixteen separate hamlets, standing near the union of their lands, than a regular town. A municipality was created in 1867 , and its income and expenditure during the ten years ending $\times 902-3$ averaged Rs. 6,900. The income in $1903-4$ was Rs. 7,200, chiefly derived from octroi, and the expenditure was Rs. 7, roo. The place formerly carried on a brisk trade with the Wazirs of the hills, which declined before annexation, but has since somewhat revived. Kulāchi contains a Government dispensary, and its principal educational institution is an Anglo-vernacular middle school maintained by the District board.

Sheikh Budin.- Hill station on the borders of Bannu and Dera Ismail Khān Districts, North-West Frontier Province, situated in $32^{\circ} 18^{\prime} \mathrm{N}$. and $70^{\circ} 49^{\prime} \mathrm{E}$., at the extremity of the 
Nìla Koh, 40 miles north of Dera Ismail Khān and 64 south of Bannu, 4,5 16 feet above sea-level. It was first occupied as a sanitarium in 1860 . Sheikh Budin is now the summer head-quarters of the Derajāt Brigade, and the civil officers of Bannu and Dera Ismail Khān Districts also spend part of the hot season here. The sanitarium crowns a bare limestone rock, which rises abruptly from the Marwat range, forming its highest point. A few stunted wild olives and acacias compose the only vegetation on the shadeless slopes. The heat is frequently excessive, the thermometer inside a bungalow ranging - from $83^{\circ}$ to $94^{\circ}$, though mitigated from June to October by a south-west breeze. Water is scarce, and in dry years has to be fetched from the bottom of the hill.

Tānk Town.- Head-quarters of the subdivision and tahsīl of the same name in Dera Ismail Khān District, North-West Frontier Province, situated in $32^{\circ} \mathrm{I} 3^{\prime} \mathrm{N}$. and $70^{\circ} 32^{\prime} \mathrm{E}$. Population (I9OI), 4,402. It stands on the left bank of a ravine which issues from the Tānk Zäm pass, 40 miles northwest of Dera Ismail Khān. It was founded by Katāl Khān, first Nawāb of Tānk. A mud wall surrounds the town, $\mathbf{2}$ feet in height and 7 feet thick, with numerous towers and two or three gates, but it is in bad repair. The fort, now in ruins, is an enormous pile of mud about 250 yards square. The walls, faced with brick, enclose a citadel 40 feet high. Tānk was declared a 'notified area' in r 893. The municipal income in $1903-4$ was Rs. 11,500 , chiefly derived from octroi, and the expenditure was Rs. 9,100. Timber and $g h \bar{\imath}$ are brought down from the hills of Waziristān in considerable quantities, while the exports include grain, cloth, tobacco, and other luxuries. Sir Henry Durand, Lieutenant-Governor of the Punjab, lost his life here in 1870 , from injuries received while passing on an elephant under a gateway. $\mathrm{He}$ was buried at Dera Ismail Khān. The military garrison has lately been withdrawn, and the post is now held by border military police. 


\section{TRIBAL AREAS, ETC.}

Dìr, Swāt, and Chitrāl.-A Political Agency in the North-West Frontier Province, lying between $34^{\circ} 15^{\prime}$ and $37^{\circ} 8^{\prime}$ $\mathrm{N}$. and $7 \mathrm{I}^{\circ} 2^{\prime}$ and $74^{\circ} 6^{\prime} \mathrm{E}$., and comprising the territories of Swāt, Dīr, Bājaur, Sam Rānizai, Utmān Khel, and Chitrāl. On the north-west and north the Agency is bounded by the watershed of the Hindu Kush. On the north-east its boundary runs from Karambar Sar, the most northerly point in Chitrāl, along the spur called the Moshabar range, which forms the watershed between the Gilgit and Chitrāl rivers. South of the Shandur pass it follows the watershed of the range which divides the Swãt and Indus valleys. On the south-east the Agency is bounded by Buner, on the south by Peshāwar District, on the south-west by the Mohmand country, and on the west by Afghānistān. After the relief of Chitrāl in 1896 Dīr and Swàt were formed into a Political Agency, to which Chitrāl, formerly under the Gilgit Agency, was added in the following year. In I90I the control of the Agency was transferred from the Foreign Department of the Government of India to the Chief Commissioner of the North-West Frontier Province. The head-quarters are at the Malakand.

Boun- Chitrāl State.-A State in the Dìr, Swāt, and Chitrāl daries, con- Agency of the North-West Frontier Province; lying between
figuration, and bill 3 and river systems.

$35^{\circ} 15^{\prime}$ and $37^{\circ} 8^{\prime} \mathrm{N}$. and $71^{\circ} 22^{\prime}$ and $74^{\circ} 6^{\prime} \mathrm{E}$., with an area of about 4,500 square miles. The State derives its name from the village of Chitrāl, situated in $35^{\circ} 5 \mathrm{I}^{\prime} \mathrm{N}$. and $7 \mathrm{I}^{\circ} 5 \mathrm{O}^{\prime} \mathrm{E}$. It comprises the whole of Kashkār Bãla or Upper Kashkãr, i. e. the Tirich valley, which runs northward from Tirich Mìr for 60 miles until it joins the Türikho valley : thence the combined streams run south for 40 miles through the Mülkho valley and join the Kho valley below Mastūj. The Türikho valley lies north-east and south-west parallel with the Yãr Khūn, and has a length of 60 miles.

The boundaries of Chitrāl are: on the north, the Hindu Kush range; on the west, Badakhshān and Kāfiristān; on the south, Dīr; and on the east, the Gilgit Agency, Mastūj, and Yāsīn.

llistory. It is recorded in a Sanskrit inscription carved on a rock 
near Barenis in Mastūj that about the year 900 A.D. the inhabitants of the surrounding country were Buddhists, and under the sway of Jaipāl, king of Kābul. A local legend tells of attacks on Chitrāl by Chingiz Khān and his Tartars, but the history of the country is practically lost before the sixteenth century. At that time a prince, whose name or title was Rais, was on the throne, and his first subject was one Sangin Alì, a foreigner of unknown origin, who however is said to have come from Khorãsān, by which is meant the hill country between Ghazni and Kandahār. Sangīn Alī died in ${ }^{1570}$, leaving-four sons, two of whom made themselves all-powerful in the country, ousting the Rais dynasty. From the second son the present Mehtar's house is descended, while the chief clans of the Adamzãdas take their names from Sangin Alī's grandsons. The ruling dynasty has thus maintained itself on the throne for more than 300 years, during the greater part of which Chitrāl, with or without Mastūj, has been constantly at war with her neighbours-Gilgit, Yāsin, the Sikh governor of Kashmir, the Chilāsis, and the Pathān tribes to the south. In r854 the Mahārājā of Kashmïr made alliance with Shāh Afzal, Mehtar of Chitrāl, against Gauhar Aman, the ruler of Yāsin and Mastūj, who was invading Gilgit, a State tributary to Kashmīr. A confused period of war and intrigue followed, in which the chief event was the unsuccessful invasion of Chitrāl in $\mathbf{1} 868$ by the ruler of Badakhshān, acting under pressure from Kãbul. From this Amān-ul-mulk, the youngest son of Shāh Afzal, finally emerged about r88o as master of Chitrāl, Mastūj, Yāsīn, and Ghizr. The Kashmīr Darbār, which with the approval of the Government of India had been in alliance with him since 1878 , in opposition to the possibility of Afghan aggression, now formally recognized him and doubled the subsidy granted to him.

In 1 885-6 Chitrāl was visited by the Lockhart mission; and in r889, on the establishment of a Political Agency in Gilgit, Amān-ul-mulk received a subsidy from the British Government of Rs. 6,000 per annum. Some rifles were also given to him. In r89r, this subsidy was increased to Rs. 12,000 , on condition that he accepted the advice of Government in all matters connected with foreign policy and the defence of the frontier.

In r892, Amān-ul-mulk died suddenly. His second son Afzal-ul-mulk, who happened to be on the spot, seized the throne. The eldest son, Nizām-ul-mulk, governor of Yāsīn, fled to Gilgit. Before Afzal-ul-mulk had fairly embarked on 
the necessary extirpation of his other half-brothers, Umrā Khān of Jandol, who was at this time master of Dir, invaded Chitrāl territory, and seized the fort and district of Narsat. Afzal-ul-mulk was about to march against him when his uncle Sher Afzal, who had been a refugee in Afghānistān, returned suddenly with a small following. Chitrāl fort was opened to him, and in the confusion that followed Afzal-ul-mulk was murdered. Sher Afzal proclaimed himself Mehtar. Nizāmul-mulk was then allowed to re-enter Chitrāl from Gilgit. Sher Afzal, believing him to have British support, fled before him and Nizām-ul-mulk in turn ascended the throne. He was recognized by Government, and a Political Agency was established in Chitrāl.

In January, 1895 , Nizāın-ul-mulk was murdered at the instigation of his half-brother Amir-ul-mulk, acting as the tool of Umrā Khān, who was still in occupation of Narsat and had espoused the cause of Sher Afzal. Amir-ul-mulk seized the fort. Umrā Khān crossed the Lawarai pass with an army, giving out that he was conducting a religious war against the infidels, and asking Amir-ul-mulk to join him. Amir-ul-mulk was unable or unwilling to comply, and Umrā Khān laid siege to Drosh, which he took after about a month's investment. Meanwhile, the Political Agent at Gilgit had been sent to Chitrāl to report on the situation. With his escort, which by reinforcements had been brought up to a strength of over 400 men, of whom 300 belonged to the Kashmir Imperial Service troops, he occupied the fort. All appeared well when suddenly Sher Afzal reappeared on the scene. He was supported by Umrā Khān, and was shortly joined by the bulk of the ruling class, the Adamzādas, with their adherents. Amir-ulmulk made overtures to them and was consequently placed under restraint in the fort, and Shujā-ul-mulk, a lad of fourteen, his brother, was provisionally recognized as Mehtar. The garrison of the fort made an ineffective sortie, and were then besieged from March 3 till April r9. During the continuance of the siege two notable successes were gained elsewhere by the enemy. The first was the treacherous capture at Būni of two British officers, the destruction of their following, and the seizure of 40,000 rounds of ammunition. The two officers were kept as prisoners by Umrā Khān at Munda for nearly a month, and were then released on the approach of the relief force. The other success was the practical annihilation near Reshung of a detachment of roo men of the r 4 th Sikhs under Captain Ross. At Chitrāl, however, the besieged, though in 
considerable straits, held out gallantly until the approach of a small force from Gilgit caused their assailants to withdraw. A week later (April 26) the advance guard of the main relief force, which had been dispatched via the Malakand and Dìr, entered Chitrāl territory over the Lawarai pass. Sher Afzal was taken prisoner and Umrā Khān fled to Afghān territory. Sher Afzal, Amir-ul-mulk, and their leading followers were deported to India, and the selection of Shujā-ul-mulk as Mehtar was confirmed. Since then Chitrāl has enjoyed an unwonted peace. The British garrison, most of which is stationed at Drosh, has been reduced to a single regiment of native infantry, relieved annually by the Swāt and Dīr route. Hospitals have been opened at Chitrāl, Mastūj, and Drosh. Cultivation has been extended and the Mehtar's revenue continues to increase, while at the same time his mental horizon has been much enlarged by his visits to Calcutta in 1900, to the Delhi Darbār in 1903, and to Peshāwar in 1904 .

Mention should here be made of the Chitrāl levies, 200 strong, who were raised in 1899 for the defence of Lower Chitrāl. In 1903 the Chitrāl Scouts were raised, with the Mehtar as honorary commandant. Their object is to provide a wholly irregular force of cragsmen for the defence of the country in case of invasion. The corps has a total strength of r,200 men, but all of these are never embodied at one time.

The present inhabitants of Chitrāl are divided into three The strata: Adamzādas, Arbābzādas, and fakīr miskin (literally, people. 'poor beggars'). The last form the majority of the population and till the soil, paying the usual tithe in revenue. The other classes are exempt from taxation. The theory that these three classes represent successive waves of invaders is probably correct, but the origin of all three is unknown. The Adamzādas at least are certainly of Aryan descent; and the language of the country, Khowār, is classed with Shinā, or the language of Gilgit, as Indo-Aryan but non-Sanskritic. The total population numbers about 50,000 .

The religion of the people is now Islām, but their conversion is recent, dating from early in the fourteenth to late in the sixteenth century, and many primitive beliefs and customs survive. Most of the people of Lut-kho belong to the Maulai sect, whose head is the Agha Khann, the chief of the Khoja community at Bombay. His agents yearly convey to him the offerings of his adherents. The local religious leaders are the pirs, to each of whom is assigned a tract of country, and under 
whom are khalifas or collectors of offerings. One tenet of the sect is said to be a belief in metempsychosis. Fanaticism is markedly absent throughout the country.

General agricultural conditions.

Manufactures and trade.

Administration.

Justice.

Revenue.
All three valleys-the Türikho, Mūlkho, and Tirich-are fertile in the extreme, and are cultivated continuously. The soil is mostly clay and gravel, and the hill-sides are generally bare. The chief crops are wheat, barley, Indian corn, and rice. Iron, copper, and orpiment of superior quality are found in Kashkār, and are mined, a few villages being almost wholly employed in the industry. Inferior cotton carpets are made for local use, and the Chitrāl daggers and swordhilts are in great demand in the neighbouring valleys.

The country is divided into eight districts, each under an $a t a \overline{l i k}$, who collects its revenue and leads its men in war. Below the atälik is the charwelo, who has charge of a group of villages, generally lying in one valley. Each village is under a baramüsh or headman, who maintains roads, forts, and bridges, assisted by a charbiu as deputy. The internal administration of the country is conducted by the Mehtar, with as little interference as possible. The foreign policy of the State is regulated by the Political Agent under the orders of the British Government.

\section{Justice.}

The precepts of the Muhammadan law are nominally enforced and the Mullās have considerable influence, often for good. Justice, however, is virtually administered at the ruler's will. Petty cases are decided by the atalik.

The regular land revenue of the country is realized solely from the fakir miskin class, who pay a tithe of their agricultural produce and other dues in kind. Shepherds also pay in kind. In practice these dues are not fixed, and as much as possible is wrung from the people. Fixed dues are also levied on the through trade with Badakhshān. The practice of selling Kho women, proverbial for their beauty, in Peshãwar, Kābul, and Badakhshān, was formerly recognized as a legitimate source of revenue, and made Chitrāl a great resort of slave-dealers. Of recent years, however, the market for slaves has become circumscribed, and the system is now limited to the sale of girl children to supply the harems of Kābul, Badakhshān, and a few other territories.

Chitrāl Town (Chitrār or Kashkār).-Town, or rather group of villages, forming the capital of the State of Chitrāl, North-West Frontier Province, situated in $35^{\circ} 5 \mathrm{x}^{\prime} \mathrm{N}$. and $71^{\circ} 5^{\prime}$ E. Population, about 2,380 . It lies on the Chitrāl river, and contains a small bazar, recently enlarged, in which 
petty traders from Bājaur and Badakhshān drive a fairly brisk trade. The Assistant Political Agent in Chitrāl resides here.

Mastūj.-Village, fort, and district subject to Chitrāl, in the Dīr, Swāt, and Chitrāl Agency, North-West Frontier Province, situated in $36^{\circ} 7^{\prime} \mathrm{N}$. and $72^{\circ} 33^{\prime} \mathrm{E}$. The village lies on the left bank of the Mastūj river, near its confluence with the Laspūr, at an elevation of 7,800 feet above sea-level. Mastūj is not, properly speaking, part of Chitrāl State. It has often been conquered by Chitrāl and has at times conquered it. At present Mastüj is governed by a Mehtarjao, an uncle of the Mehtar' of Chitrāl, who is independent of him, though Mastūj is part of the Chitrāl Agency. The climate in winter is severe, owing to the cold winds which blow down the valleys. An inscription at Barenis, a neighbouring village on the right bank of the Mastūj river, shows that Chitrāl was included in the kingdom of Jaipāl, king of Kābul, about A. D. 900, and that its inhabitants were then Buddhists. Its history is that of CHITRĀL, and it has a population of about 6,000 .

Dir.-One of the territories included in the Dīr, Swāt, and Chitrāl Agency, North-West Frontier Province, lying between $35^{\circ} 50^{\prime}$ and $34^{\circ} 22^{\prime} \mathrm{N}$. and $71^{\circ} 2^{\prime}$ and $72^{\circ} 30^{\prime} \mathrm{E}$. It takes its name from the village of Dīr, the capital of the Khān, which lies on the Dīr stream, an affluent of the Panjkora. Politically, the Dir territory comprises the country drained by the Panjkora and its affluents down to the junction of the former river with the Bājaur or Rūd, and also the country east of this from a point a little above Tìrāh in Upper Swāt down to the Dush Khel country, following the right bank of the Swāt river throughout. The upper portion of the Panjkora valley down to its confluence with the Dirr is called the Panjkora Kohistān or Kohistān-i-Malizai, and of this Kohistān or 'highland' again the upper portion is called Bashkarr and the lower Sheringal. The valley of the Dīr is also known as Kashkār. At Chutiātan, 6 miles below Dir, the Panjkora is joined by the Dir and Baraul rivers, and the valley of the latter now forms a part of Dīr. The Maidān valley, which runs into the Panjkora Io miles above its junction with the Rüd on the right bank, and the Jandol, which joins the Rüd above its confluence with the Panjkora, are also included in Dir, as are the Dush Klel country, between the Swāt and Panjkora, and the Talāsh valley. The population of Dīr, including all its dependencies, is probably about 100,000; and its area, including the Dîr Kohistān, of which the boundaries are ill-defined, is about 5,000 to 6,000 square miles. 
The main Panjkora valley is not so wide as that of Swãt, and contains much less alluvial soil; but it is joined by numerous rich lateral valleys, and the greater part of the population lives in these. The upper slopes of the hills are thickly wooded, and the Kohistān contains valuable deodār forests. The rainfall exceeds that of Swāt ; but though the upper valleys have a pleasant climate, the lower, as in Lower Swăt, are hot in summer and unhealthy in autumn. The history and trade are dealt with in the article on SwĀT.

The Khān of Dīr is the overlord of the country, claiming and, when in a position to do so, exacting allegiance from the petty chieftains of the clans, and revenue from the cultivators. Revenue when taken is always the tenth share of the produce (ushar) prescribed by Muhammadan law. The country, wherever agriculture is possible, is cultivated and bears rich crops ; but the communal system of tenure, with its periodical redistribution of holdings, causes slovenly methods to be universal.

Dīr is mainly held by Yūsufzai Pathāns, its old non-Pathān inhabitants, the Bashkārs, being now confined to the valley of that name. Both Bashkār and Kashkār have also a considerable Gujjar population. The language of the Pathanns is the pure Yūsufzai Pashtū; but in the Panjkora Kohistān the Bashkārs speak a dialect of their own resembling the Garbwi of the Swāt Kohistān, and the Güjars still retain their own language, which resembles Punjābi. The Dìr levies, which maintain the security of communications, number 390 , including 40 mounted men.

Swāt State.-One of the tracts comprised in the Dirr, Swāt, and Chitrāl Agency, North-West Frontier Province, lying between $34^{\circ} 40^{\prime}$ and $35^{\circ} \mathrm{N}$. and $72^{\circ}$ and $74^{\circ} 6^{\prime} \mathrm{E}$. It forms the valley of the Swàt river, which, rising in the lofty ranges bordering on Chitrāl, flows south-south-west from its source to Chakdarra, thence south-west to the Malakand, thence north-west to its junction with the Panjkora, thence south-west again till it meets the Ambahār, thence south-east to Abāzai in Peshāwar District. Below its junction with the Panjkora the valley is not, politically speaking, Swāt but Utmān Khel. Swāt is divided into two distinct tracts : one, the Swāt Kohistān, or mountain country on the upper reaches of the Swāt river and its affluents as far south as Ain; and the other, Swāt proper, which is further subdivided into Bar ('Upper') and Kuz ('Lower') Swāt, the latter extending from Landakai to Kalangai, a few miles above the junction of the 
Swăt and Panjkora rivers. The area of Swāt, including Swăt Kohistān, is about the same as that of Dirr; but the river valley does not exceed 130 miles in length, with an average breadth of about 12 miles. 'I'he valley contains a series of rich alluvial tracts, extensively cultivated and extending for 70 miles along the river banks, while in the Kohistãn are vast forests of deodār. Starting from an elevation of 2,000 feet, at the junction of the Swāt and Panjkora, the valley rises rapidly, and the peaks' to the north range from 15,000 to 22,000 feet in height. The climate of the lower valleys is malarious and unhealthy, especially in autumn.

The histories of Dīr, Swāt, Bãjaur, and Utmān Khel are so inextricably intermingled that it has been found impossible to treat them separately.

The first historical mention of these countries is made by Arrian, who records that in 326 B.c. Alexander led his army through Kunar, Bājaur, Swāt, and Buner; but his successor, Seleucus, twenty years later made over these territories to Chandragupta. The inhabitants were in those days of Indian origin, Buddhism being the prevailing religion, and they remained thus almost undisturbed under their own kings until the fifteenth century. They were the ancestors of the nonPathān tribes, e.g. Gūjars, Torwāls, Garhwīs, \&c., who are now confined to Bashkār of Dīr, and Swāt Kohistān.

The invasion of the Yūsufzai and other Pathān tribes of Khakhai descent, aided by the Utmān Khel, then began ; and by the sixteenth century the Yussufzai were in possession of Buner, Lower Swāt, and the Panjkora valley; the Gigiannis and Tarkilanris had established themselves in Bājaur, and the Utmann Khel in the country still occupied by them. The advent of these Pathān invaders introduced the Muhammadan religion throughout these countries. At this time the emperor Bābar, by a diplomatic marriage with the daughter of Malik Shāh Mansūr, the head of the Yūsufzai clans, and by force of arms, established his sovereignty throughout Bãjaur (except Jandol), the Panjkora valley as far as its junction with the Bājaur, and Lower Swāt. Upper Swāt, which was still held by the aboriginal Swãtis under Sultān Udais or Wais, tendered a voluntary submission, claiming protection from the invader, which Bābar gave. In Humāyūn's reign, however, the advance was continued, and the Yũsufzai overran the Sheringal portion of Dỉr and Upper Swāt as far as Ain, beyond which they have scarcely advanced to this day. Humāyün's yoke was rejected by them, and even $A \mathrm{kbar}$ in ${ }_{1584}$ could exact no more than a 
nominal submission. Such degree of peace as obtains amongst independent Pathãn tribes was enjoyed by the Yussufzai and their neighbours, until a fruitful cause of dissension arose in Dìr in the person of a religious reformer named Bazìd, called by his adherents the Pir-i-Roshan, whose chief opponent was Akhund Darweza Bāba, the historian of the Yūsufzai. The heresy of the Pïr and the constant depredations of the combatants on either side at length compelled interference. Zain Khān, Kokaltāsh, was deputed by thè governor of Kābul to bring the tribes to reason, and after five years' fighting and fort-building he effected in 1595 a thorough conquest of the country. By $165^{8}$, however, in which year Aurangzeb ascended the throne, the lesson had been forgotten. The tribes refused to pay revenue, declared their independence, and maintained it till the time of Nādir Shāh, whose successors, Ahmad Shāh Durrānī and Tìmür Shāh, kept their hold on the country. The grasp was not altogether lost by those who came after, and when Azìm Khān attacked the Sikhs in 1823, the Yüsufzai sent a large contingent with his army. They were defeated, and Ranjīt Singh entered Peshāwar, but did not essay a farther advance into the northern hills.

In 1829 the colony of Hindustāni fanatics which still exists in Amarzai country was founded by Mīr Saiyid Ahmad Shāh of Bareilly. But the austerities enjoined by the Mìr were his undoing. A conspiracy was formed; his chief followers were murdered in a single night, and he himself was hunted down and killed at Bālākot in Hazāra in 1831 . The primacy then passed to Abdul Ghafür, the famous Akhund, who established himself in 1835 at Saidu in Upper Swāt, where he lived until his death in 1877 , the most powerful man in the country.

On the establishment of British rule in the Peshāwar valley (1849), no attempt was made to penetrate into the hill country. But the raids of the tribesmen in British territory, and the asylum which they afforded to outlaws and desperadoes, could not be suffered to pass unnoticed; and punitive expeditions were sent in $r 849$ against the Utmān Khel, and in 1852 against both this tribe and the inhabitants of Sam Rānizai, the country between the District border and the Malakand Pass. Severe punishment was inflicted in the second expedition. The year of the Mutiny (1857) passed off without disturbance, a refuge in Swat being actually denied to the mutineers of the $55^{\text {th }}$ Native Infantry by the Akhund, who, however, adopted this course for reasons of local policy, not from love of the British Government. In $186_{3}$ took place the expedition against 
the Hindustanni fanatics resulting in what is known as the Ambela campaign, in which the united forces of Swāt, Bājaur, Kunar, and Dir were arrayed under the banner of the Akhund against the invading force. In 1866 , another small expedition was sent to punish the Utmān Khel, after which there was peace on the border till, in 1878 , force had again to be used. The Guides were sent against the people of Rannizai and the Utmān Khel, with complete success in the restoration of order. Early in 1877 the Akhund died, and his son, attempting to succeed to his position, was bitterly opposed by the Khann of Dir. The whole country as far as Nawagai in Bājaur was embroiled, and in the confused fighting and tortuous diplomacy that followed Umrā Khān of Jandol, a scion of the royal house of Bājaur, took a prominent part. Allying himself first with the Miān Gul, the son of the Akhund, by 1882 he had conquered and taken from the Khān of Dīr nearly half his country. In 1882, the Miān Gul became jealous and fell out with Umrā Khān, making terms with the Khān of Dīr. Umrā Khān's position was rendered more difficult next year by the arrival in the Utmān Khel country of a religious leader, said to have been sent from Kābul to thwart him, and known as the Makrāni Mullā. His denunciations effected in 1887 a combination of the whole country-side, including Dīr, Nawagai, Swāt, Utmān Khel, Salarzai, and Māmund, against Umrā Khān. But the allies were defeated, quarrelled one with another, and dispersed; and by 1890 , the Mulla having fled the country, Umrā Khān was master of the whole of Dīr territory, the Khān (Muhammad Sharīf) being in exile in Swāt. Ever since I884 Umrā Khān had been coquetting with the British authorities, in the hope of being furnished with rifles and ammunition. In 1892 he accepted, in return for a subsidy, the task of keeping postal communications open with Chitrāl, and thereafter began to intrigue on the death of the great Mẹhtar Amān-ul-mulk in the affairs of that country. The Asmār boundary commission in 1894 augmented the coolness between the Government and Umrā Khān, which came to open hostility in the next year (see CHITRÃL), and as a result of his defeat Umrā Khān fled in 1896 to Kābul. The Khān of Dīr at once returned to power and entered into agreements with the Government for keeping the Chitrāl road open, without toll, as also did the clans of Swāt, subsidies being granted to both. 'In the year after the Chitrāl expedition, the Political Agency of Dīr and Swāt was constituted, and posts were built at Chakdarra, in Lower Swāt, the Malakand, and Dargai in the 
Ranizai country. Chitrăl was shortly added as an apanage of the Agency, having been hitherto connected with Gilgit. The disturbance of the country caused by the events of 1895 , the intrigues of Afghann officials, and the natural animosity of the religious classes after a period of apparent calm, during which the title of Nawăb was conferred on the Khān of Dirr, led to the rising of 1897 , in which a determined effort was made by the tribesmen mustered by the Mullā Mastān ('Mad Mulla') of Swät to storm the posts at Chakdarra and the Malakand. Their attacks were repulsed, though not without difficulty; and in the punitive operations which followed columns were sent to enforce the submission of the Māmunds in Bājaur, the Yūsufzai of Swāt, and the Bunerwāls. No action against Dīr was necessary, for the Nawāb had been able to restrain his people from overt hostility.

In I 901 a railway was opened from Naushahra to Dargai at the foot of the Malakand Pass. Tribal fighting has continued intermittently, but no event of importance took place in the Agency after 1897, until the death of the Nawāb of Dîr in 1904. His eldest son Aurangzeb (Bādshāh Khān) has been recognized as the successor, but the succession is disputed by Miān Gul Jān, his younger brother.

Swāt proper is now peopled by the Akazai branch of the Yūsufzai Pathāns (about 150,000 in number), and the Kohistān by Torwāls and Garhwiss (estimated at 20,000). The Yūsufzai comprise various clans. On the left bank of the river lie the Rānizai and Khān Khel in Lower Swāt, and the Sulizai and Bābuzai in Upper Swät. On the right bank are the Shamizai, Sabujni, Nikbi Khel, and Shamozai in Upper Swāt, and in Lower Swāt the Adinzai, Abāzai, and Khadakzai clans. All the clans on the right hank, except the two last named, are collectively known as the Khwazozai; and all except the Rānizai on the left are collectively called the Baezai. The whole valley and the Kohistān are well populated; but before 1897 the Swāti Pathāns had not the reputation of being a fighting race, and owing to the unhealthiness of the valley their physique is inferior to that of Pathāns generally. The language of the people is the pure Yūsufzai Pashtū, except in the Kohistān where the Torwāls and Garhwiss speak dialects of their own, which is said to resemble very closely the dialect of Hindkī used by the Gūjars of Hazāra.

The people are by religion Muhammadans of the Sunni sect, those of the Kohistān, as recent converts, being peculiarly ignorant and fanatical. The shrine of the great Akhund of 
Swat, at Saidu, is one of the most important in Northern India. Born of Gūjar parents, probably in Upper Swāt, Abdul Ghafūr began life as a herd-boy, but soon acquired the titles of Akhund and Buzurg by his sanctity, and for many years resided at Saidu, where he exercised an irresistible influence over the Yūsufzai and their neighbours. His grandsons have inherited some of his spiritual influence. The offerings at the Akhund shrine and subscriptions received from their followers afford them a considerable income. A still living religious leader is the Mullā Mastān, or 'Mad Mulla' (also called the sartor or bare, literally 'black-headed' $f a k \bar{i} r$ ), Sad-ullah Khān. By birth the son of a Bunerwail malik and a great athlete in his youth, he spent some years at Ajmer and returned to Buner in 1895 . His piety soon made him widely known in the Swāt and Indus Kohistān, and his religious fervour earned him his title of Mastān.

Malakand.-A pass which crosses the range north of Peshāwar District, North-West Frontier Province, and leads from Sam Rānizai into the Swāt valley, situated in $34^{\circ} 34^{\prime} \mathrm{N}$. and $71^{\circ} 57^{\prime} \mathrm{E}$. The pass is traversed by an ancient Buddhist road. Early in the sixteenth century the Yüsufzai Pathāns effected their entrance into Swãt by the Malakand, and in $15^{8} 7$ Zain Khān, a general of the emperor Akbar, built a fort here. In 1895 the pass was taken by the Chitrāl relief force, and has since been occupied as a military post, near which is also the head-quarters of the Dīr, Swāt, and Chitrāl Political Agency. On July 26, 1897, the post was suddenly attacked by a large gathering of Swätis under a fanatical leader, the Mullā Mastān or 'Mad Mullā.' Tribesmen from Utmān Khel and Upper Swāt poured in, raising the numbers to I 2,000 men. Fighting continued until August I, when the tribes were repulsed. Chakdarra, which also was besieged by the tribesmen, was relieved the next day.

Chakdarra.-A military post to the north-east of the Malakand Pass, on the south bank of the Swãt river, in the Dĩr, Swāt, and Chitrāl Agency, North-West Frontier Province, situated in $34^{\circ} 44^{\prime} \mathrm{N}$. and $72^{\circ} 8^{\prime} \mathrm{E}$. Like the Malakand, it was fortified by Akbar's general Zain Khằn in $15^{87}$, in his attempt to conquer Swāt. In 1895 the Chitrāl relief force crossed the Swàt river at Chakdarra, which 1 was garrisoned and retained as an outpost on the conclusion of the campaign. In July, I897, Chakdarra was besieged by 8,000 tribesmen who had attacked the Malakand under the Mullā Mastān or 'Mad Mulla,' but its hard-pressed garrison was relieved on August 2. 
Bājaur.-A tract of country in the Dỉr, Swāt, and Chitrāl Agency, North-West Frontier Province, lying between $34^{\circ} 25^{\prime}$ and $35^{\circ} 5^{\prime} \mathrm{N}$. and $70^{\circ} \mathrm{I}^{\prime}$ and $72^{\circ} \mathrm{E}$. It comprises five valleys : namely, Chahārmung, Bābūkara, Watalai (or Ut-lai), Rūd in the valley of the Rūd river, and the Sūr Kamar valley, in which lies Nawagai. In the last, the Nawagai, Chamarkand, and Suran ravines unite to form the Ripal, or Ambahār river, which falls into the Swăt some distance below its junction with the Panjkora. Bājaur is bounded on the north by the Panjkora river; on the east by the Utmān Khel and Mohmand territories, the latter also bordering it on the south; and on the west by the crest of the eastern watershed of the Kunar river, which divides it from Afghānistān. Its population probably amounts to 100,000 , and its area to nearly 5,000 square miles. Lying at a lower elevation than Dīr, Bājaur has a smaller rainfall, and the snowfall on the range in which the affluents of the Rüd take their rise is also slight. In consequence, the hills are not well wooded; and though the Rūd, the most important of the five valleys, is very fertile, Bābūkara, Chahārmung, and Watalai are not so productive. The history of the tract is dealt with in the article on Swàt.

The Rūd valley is peopled by various Pathān tribes, Tarkanri or Tarkilanri Yūsufzai, Mohmands, Sāfis, Utmān Khel and others. Chahārmung and Bābūkara are held by the Salarzai, and Watalai by Māmunds, both sections of the Tarkanri. The political system, if it can be termed system, is a communal form of party government, subject to the control of the Khān of Nawagai, who is nominally the hereditary chief of all Bājaur. Under him the country is divided into several minor Khānates, each governed by a chieftain, usually a near relative of the Khān. But virtually the authority of the chieftains is limited to the rights to levy tithe, or ushar, when they can enforce its payment, and to exact military service if the tribesmen choose to render it. Public, or rather tribal, affairs are managed by the jirga or assembly of the party in power, and in this assembly each landowner has a vote.

Utmān Khel.-A mountainous tract of country between the Rūd and Amabhār rivers, and thence eastwards between the Swāt river and Peshāwar District, as far as the Rānizai border, in the Dīr, Swāt, and Chitrāl Agency, North-West Frontier Province, lying between $34^{\circ} 15^{\prime}$ and $34^{\circ} 50^{\prime} \mathrm{N}$. and $7 \mathrm{I}^{\circ} \mathrm{I}^{\prime}$ and $7 \mathrm{I}^{\circ} 5 \mathrm{O}^{\prime} \mathrm{E}$. It is bounded on the east by Swāt; on the south by the Hashtnagar portion of Peshāwar District; on the west by the Mohmand country; and on the north 
by Dir and Bajjaur. The tract lies on both banks of the Swāt river, and derives its name from the Utmān Khel or tribe of Afghāns who occupied it in the sixteenth century, at the time of the Yüsufzai conquest of the Swāt. The tribe is estimated to number about 40,000 , and is divided into many clans, constantly at feud among themselves. Their country, of which the area is about 3,000 square miles, is a network of bare hills and ravines, infertile except in some strips along the southern bank of the Rüd. Besides this tract, the Utmān Khel also own a few villages east of Landkhwar between Peshāwaí District and Sam Rānizai. The Utmān Khel have frequently given trouble to the British, necessitating punitive expeditions in 1852,1878 , and 1898 .

Buner.-A tract of country lying between $34^{\circ} 22^{\prime}$ and $34^{\circ} 37^{\prime} \mathrm{N}$. and $72^{\circ} 15^{\prime}$ and $72^{\circ} 48^{\prime}$ E., on the north-east border of Peshāwar District, North-West Frontier Province. Its boundaries are: on the north, Swāt Kohistān; on the west, Swāt and Sam Rānizai ; on the south, dependent tribes and Peshāwar District ; on the east, the Black Mountain and Hazāra District. Political control is exercised by the DeputyCommissioner of Peshāwar through the Assistant Commissioner at Mardān. Buner comprises the basin of the Barandu river, which joins the Indus near Amb. The main valley of the Barandu is about ro miles broad, well-cultivated, and level ; and though the side valleys are narrower and less fertile, they are better wooded. The aloofness of the inhabitants, arising from the fact that no trade arteries pierce the country, is very marked. They are, however, recognized by the clans who live between Buner and Peshâwar District, such as the Gaduns, Salarzai, Khudu Khel, \&c., as the head of their confederacy.

The history of Buner is given in the article dealing with SwĀT. Buner with the neighbouring countries was included in the ancient kingdom of Udyãna, and abounds in archaeological remains of great interest, which date from the Buddhist era. The places most interesting from an archaeological view in Buner, or in the territory of tribes dependent on it, are Mahāban, Banj, Asgram, Panjkotai, Gumbatai, and Girārai. Mahāban has been conjecturally identified with Aornos, the rock besieged by Alexander; but the latest view, that of Dr. Stein, who visited Mahāban under tribal escort in 1904, is that the topography of Aornos is inapplicable to Mahāban, and that the real Aornos, if there be such a place, must be sought elsewhere. In the same tour Banj was examined; and the suggestion has been made that it is the famous place of 
Buddhist pilgrimage, at which a shrine was built to commemorate the offering of his body by the Buddha to feed a starving tigress. The buildings described by the Chinese pilgrims are now completely in ruins and all sculptures have been removed.

The ruins at Asgram are of some interest, and the place has been identified with the Asigramma of Ptolemy. Buner proper was traversed by Dr. Stein in January, 1898 , with the force dispatched for the punishment of the Bunerwals. In the report then published, reasons were set forth for the identification of Panjkotai with the site of the famous Mahãwana monastery described by the Chinese pilgrims, of Gumbatai (Tursak) with the Mosu monastery and shrine, and of Girārai with the shrine commemorating Buddha's ransoming of a dove, also a place of pilgrimage.

Ambela.-A mountain pass in Buner, just beyond the northeast border of Peshāwar District, North-West Frontier Province, situated in $34^{\circ} 24^{\prime} \mathrm{N}$. and $72^{\circ} 3^{\prime} \mathrm{E}$. The pass gave its name to the Ambela campaign of 1863 . In 1824 , one Saiyid Ahmad Shāh of Bareilly, a companion-in-arms of the famous Amir Khān, the Pindāri, settled with about forty followers among the Yūsufzai tribes on the Peshāwar border. This event occurred just after Ranjit Singh had gained his great victory over the Pathāns at Naushahra. Driven out of the Peshāwar valley by the Sikhs in 1827 , Saiyid Ahmad sought refuge in Swāt, and eventually in Buner, but in 1829 he seized Peshāwar. His Pathān disciples, however, soon tired of his attempted reforms, and drove him across the Indus to Bālākot in Hazāra. There he was attacked by the Sikhs under Sher Singh, and defeated and slain. His surviving disciples sought a refuge at Sittāna, a village of the Utmānzai Yūsufzai. Here under Saiyid Akbar Shāh, spiritual chief of Swāt, the Hindustāni fanatics built a fort and established a colony, which soon became an asylum for political refugees, escaped criminals, and deserters from British India. After the annexation of the Punjab, this colony became a source of anxiety to the Government, and in 1853 an invasion of the territory of the Khan of Amb, a British feudatory, necessitated a punitive expedition. The fanatics displayed renewed activity in 1857 , and in I $85^{8}$ made a daring attack on the camp of the Assistant Commissioner of Mardān, necessitating a second punitive expedition. The tribes then agreed not to allow the colony to reoccupy Sittanna, and they settled at Mālka on the northern side of the Mahāban mountain. From this settlement they renewed their depredations, which consisted chiefly in kidnapping Hindu 
traders from Hazāra, and in 1863 they reoccupied Sittāna. Drastic measures now became unavoidable, and two columns, one from Peshāwar and the other from Hazāra, were organized. The former, under Sir Neville Chamberlain, 9,000 strong, occupied the Ambela Pass, the object being to march through the Chamla valley and attack Sittāna. The tribes of Buner and Swāt, however, rose en masse and made repeated attacks on the British positions in the pass. After protracted operations the pass was secured and the advance into the Chamla valley carried out ; but the expedition lost 20 officers ( 16 British and 4 native) and 219 men killed and 670 wounded. The object of the expedition was, however, attained. Mãlka, which had been made the chief stronghold of the Hindustanni fanatics, was destroyed by the people of Buner themselves as a guarantee of their submission, and the colony has never recovered its former power.

Mohmand Country.-A tract north-west of Peshāwar District, North-West Frontier Province, lying between $33^{\circ} 30^{\prime}$ and $34^{\circ} 40^{\prime} \mathrm{N}$. and $70^{\circ} 30^{\prime}$ and $71^{\circ} 30^{\prime}$ E., with an area of about I,200 square miles. Its boundaries are : on the east and north, the Swāt and Ambhār rivers ; on the west, the Afghān territory of Kunar; and on the south, the watersheds of the Käbul river. Those of the Mohmands who live west of the Afghān boundary are subject to the Amir. The majority of the tribe, who live between Afghannistān and the border of Peshāwar District, are under the political control of the Deputy-Commissioner of Peshāwar; but there is an increasing tendency to settle in the District, in the doabss between the rivers. The Mohmand settlers seldom remain, however, during the summer months, being what is described as Do-Kora ('two homes'). The tract is naturally divided into the rich alluvial lands along the Kābul river from Jalālābād to Lālpura, and a network of hills and valleys from Lālpura eastward. The aspect of the Mohmand hills is dreary in the extreme, coarse grass, scrub wood, and dwarf palms being the only vegetation. In summer the desert tracts radiate an intolerable heat, and water is scarce. This, coupled with the unhealthiness of the river lowlands, accounts for the inferiority of the Mohmands to their Afridi and Shinwāri neighbours in physique, and they are little recruited for the Indian army. The crops are largely dependent on the rainfall, and, should this fail, considerable distress ensues. The hills, indeed, cannot support the population. The country exports little except grass, firewood, dwarf-palm, and charcoal. But there is a considerable through trade, the 
carrying of which supplements the people's resources. They also levy dues on the timber rafted down from Kãbul. Since the Khyber Pass was opened, however, the routes through the Mohmand country have lost much of their importance. The Mohmands are closely allied to the Yūsufzai Pathāns. Under them are two vassal tribes: the Sāfis, probably Kāfirs converted to Islām, of whom little is known; and the Mullagoris, who inhabit the country between the Kābul river and the Khyber Pass. This tribe is a small one and cannot muster more than 500 to 800 fighting-men, but has now for many years maintained its independence and denies ever having held a position of subordination to the Mohmands. The Mohmands formed one of the group of Afghān tribes which, driven eastward by Mongol inroads between the thirteenth and fifteenth centuries, overran the country west and north of Peshāwar District, expelling or subduing the Hindu and non-Afghān races. Their success was in great measure due to their possession of hereditary chiefs or Khāns, who kept together forces which have gradually worn down the resistance of the disunited Shinwãris. The chief of these is the Khān of Lālpura, but there are several minor Khāns, and one family claims that title as the hereditary guardian of the sarishta or code of tribal law and custom. The Khāns of Lālpura, at various times, owed allegiance to Akbar and Shāh Jahān, to Nādir Shāh and Ahmad Shāh Durrāni. About 1782, however, Arsala Khān of Lālpura revolted against Tīmūr Shāh Durrāni, but was compelled to submit, and was executed at Peshāwar in r79r. Thereafter the history of the family is one of constant bloodshed. Saādat Khān, who held the Khānship for forty years, was a faithful vassal of the Bārakzai dynasty of Afghānistān, but in 1864 he was arrested by the Amir for constant aggressions on the British border and died a prisoner at Kābul. After a period of anarchy, Akbar Khān was appointed in I 880 by the British Government. His extravagance and dissipation, however, greatly diminished his influence, and in 1896 he resigned his position and now lives at Kābul. In 1896 also the Utmanzai, Dāwezai, Halimzai, Tarakzai, and Pindiāli Mohmands came under the sole control of the British Government, and have received allowances from that date. In 1903 allowances were also fixed for the Musa Khel Mitai Mohmands. The Mohmands have a great reputation for bravery among the neighbouring tribes, and can muster about 18,000 fighting-men. They are fairly well armed.

During the early period of British rule the Mohmands gave 
more trouble than any other frontier tribe, and for many years their history was a series of wanton outrages in British territory, culminating in the unprovoked murder of a British officer in 1873 , and followed by the usual punitive expeditions. In I 895 the Mohmands, with no other justification than the Adda Mullā's fanatical preaching, joined in the resistance to the Chitrāl relief force. In 1897 , they were among the first to raise the standard of $j i \hbar \bar{\alpha} d$ against the British power, and attacked SHABKaDAR. The Mohmand country was accordingly invaded from Bājaur by two brigades of the Malakand field force under Sir Bindon Blood, and from Shabkadar by two more under Sir Edmond Elles.

A branch of the tribe has settled in the south-west corner of Peshāwar District, and is now quite separate from the main body.

Khyber (Khaibar).-The celebrated pass leading from Situation. Peshãwar District in the North-West Frontier Province into Afghānistān, the centre of the pass lying in $34^{\circ} 6^{\prime} \mathrm{N}$. and $71^{\circ} 5^{\prime} \mathrm{E}$. The name is also applied to the range of hills through which the pass runs. The Khyber mountains form, indeed, the last spurs of the Safed Koh, as that mighty range sinks down into the valley of the Kābul river. The elevation of the connecting ridge is 3,400 feet, but it rises to 6,800 feet in the Tārtara peak. On either side of it are the sources of two small streams, one flowing north-west to the Kābul river, the other south-south-east towards Jamrūd. The beds of these streams form the Khyber defile.

The Khyber Pass is the great northern route from Afghān-Descrinistān into India, while the Kurram and Gomal Passes form tion. intermediate communications, and the Bolann Pass is the great southern passage. The pass begins near Jamrūd, $1 \circ \frac{1}{2}$ miles west of Peshãwar, and twists through the hills for about 33 miles in a north-westerly direction till it debouches at Dakka. The most important points en route are Alī Masjid, a village and fort $10 \frac{1}{4}$ miles from Jamrūd; Landi Kotal, the summit of the pass, ro miles farther; and Tor Kham, at which point the pass enters Afghān territory, about 6 miles beyond Landi Kotal. The plains of Peshāwar District stretch from the eastern mouth of the pass, and those of Jalālābād from the western. Outside the eastern gate is the remarkable collection of caves at Kadam, and beyond its western limits are many interesting reniains of Buddhism and of ancient civilization. The pass lies along the bed of a torrent, chiefly through slate rocks, and is subject to sudden floods, especially in July, 
August, December, and January. The gradient is generally easy, except at Landi Khanna, and the road is in good condition.

The elevation, in feet, at various points of the pass is: Jamrūd, r,670; Alī Masjid, 2,433; Landi Kotal, 3,373; Landi Khăna, 2,488; Dakka, 1,404. The ascent over the Landi Khāna pass is narrow, rugged, steep, and generally the most difficult part of the road. Guns could not be drawn here except by men, and then only after the improvement of the road; the descent is a well-made road, and not so difficult. Just beyond Ali Masjid the road passes over a stretch of uneven and slippery rock, which is extremely difficult for laden animals. The Khyber can be turned by the Mullagori road, which enters the hills about 9 miles north of Jamrūd, and either joins the Khyber road or keeps to the north of the range and emerges at Dakka.

History. The Khyber has always been one of the gateways into India. Alexander of Macedon probably sent a division under Hephaistion and Perdiccas through the Khyber, while he himself followed the northern bank of the Kābul river, and thence crossed the Kunar valley into Bājaur and Swāt. Mahmūd of Ghazni only once used the Khyber route, when he marched to encounter Jaipāl in the Peshãwar valley. The Mughal emperors Bābar and Humāyūn each traversed it more than once. Nādir Shāh, advancing by it to attack Nāsir Khān, Sübahdār of Kābul under the Mughal government, was opposed by the Pathāns; but he led his cavalry through Bāzār, took Nāsir Khān completely by surprise, and ovêthrew him near Jamrūd. Ahmad Shāh Durrāni and his grandson Shāh Zamān, in their invasions of the Punjab, also followed the Khyber route on several occasions. The Mughal emperors attached great importance to the control of the Khyber, but were singularly unsuccessful in their attempts to keep the route open. Then, as now, it was held by the Afrīdi Pathāns, a race implacably hostile to the Mughals.

Jalālābād, first fortified by Humāyūn in 1552, was further strengthened by his son Jalāl-ud-din Akbar, after whom it was named; and the latter emperor so improved the road that wheeled carriages could traverse it with ease. But even in his reign the Khyber was infested by the Roshānia sectaries, who wielded great influence over the Afghān tribes; and the Rājput general Mãn Singh had to force the pass in 1586 , when Akbar desired to secure possession of Kābul on the death of his brother Mirza Muhammad Hakim. In 1672, under Aurangzeb, the tribes waylaid the Sübahdār of Kābul, 
Muhammad Amīn Khān, in the pass, and annihilated his army of 40,000 men, capturing all his treasure, elephants, women, and children.

The first British advance into the Khyber was in 1839, British exwhen Captain Wade was deputed to conduct Shāhzāda Tìmūr peditions. to Kābul via Peshãwar, while his father Shāh Shujā was escorted thither by the army of the Indus via the Bolan Pass and Kandahār.

During the first Afghãn War the Khyber was the scene of First many skirmishes with the Afrìdis and of some disasters to our Afghän troops:- Captain Wade, with from 10,000 to $1 \mathrm{I}, 000$ of all arms, including the Sikh contingent, moved from Jamrūd on July 22, 1839, to Gāgri ; here he halted a day and entrenched his position; on July 24 he again marched to Lāla Chīna; on the $25^{\text {th }}$ he moved to the attack of Ali Masjid, sending a column of 600 men and 2 guns, under Lieutenant Mackeson, to the right and I I companies of infantry, one 6-pounder gun, and one howitzer to the left; while below a column was placed to watch the mouth of Shädi Bagadi Gorge. Both columns drove the enemy before them, the right meeting with some opposition, and the left getting into a position to shell the fort. On the 26th all the enemy's outposts were driven in, and on the 27 th they evacuated the fort. The enemy had 509 jazailchis, or musket-men, and were supported by several hundred Afrïdis. The British loss was 22 killed and 158 wounded. After this there was no further opposition.

A strong post was left in Ali Masjid and a detachment near Lāla Chīna to maintain communication with Peshāwar, and a post of irregulars under Lieutenant Mackeson was placed near Dakka. The post near Lâla China was attacked during the operations. It was garrisoned by Yūsufzai auxiliaries, whose numbers had been thinned and the survivors worn down by continued sickness, when the Afrïlis, estimated at 6,000 strong, attacked their breastwork. They were long kept at bay, but the marauders were animated by the lust of plunder, and persevered in their attacks. They were aware that the devoted garrison had recently received their arrears of pay, and that a sum of Rs. 1 2,000 was buried on the spot. Finally, they carried the weak fieldwork, and put to the sword 400 of its defenders. They did not keep possession of it, but, after repeating their vain attempts on Ali Masjid and the posts in the valley, retired to their mountains.

When Jalālābād was blockaded, it was proposed to send a force through the Khyber to its relief, and as a preliminary 
measure Lieutenant-Colonel Moseley was detached to occupy Ali Masjid with two regiments of native infantry. He marched on the night of January 15,1842 , and reached the place with little opposition the next morning. Through some mismanagement, however, only a portion of the provisions requisite for the two regiments accompanied them. It became necessary, therefore, to forward the residue without delay; and Brigadier Wilde advanced from Jamrūd with the remaining two regiments (the 6oth and 3 oth native infantry and 4 Sikh guns). But the appearance of Colonel Moseley's detachment had alarmed the Afridis, who now rose and, closing the pass, prepared to resist Brigadier Wilde's entrance. The Brigadier nevertheless pushed onwards on January 19, and encountered the enemy at the mouth of the pass; but, owing to the uselessness of the Sikh guns and the inadequacy of his force with so powerful a body of the enemy advantageously placed in his front, his attempt to reach Ali Masjid totally failed. The situation of Lieutenant-Colonel Moseley, shut up in Alī Masjid, with scarcely any provisions, now became desperate; but he was successful in forcing his way back to Jamrūd.

The next occasion on which the Khyber was used as a great military road was when General Pollock advanced on April 6, I842. On his return to India the British army marched through the Khyber in three divisions. The first, under General Pollock, passed through with no loss. The second, under General M'Caskill, was not equally fortunate. One brigade being overtaken by night left two mountain-train guns with the rear guard, which was suddenly attacked, and the guns were taken, but recovered next day. The rear guard of General Nott's force was also attacked on November 5 and 6 between Landi Khãna and Lālabāgh, and again on leaving Alī Masjid.

Second Afghān War.

It was at Ali Masjid in 1878 that Sir Neville Chamberlain's friendly mission to the Amīr Sher Alī Khān was stopped and repelled with threats. An ultimatum was therefore handed to the Amir's general, Faiz Muhammad, in Ali Masjid; and the day specified having passed without the return of an answer, Afghānistān was invaded by three British columns, one of which started from Jamrūd at the mouth of the Khyber.

On the second day of the campaign the fortress of Ali Masjid was brilliantly captured by the British troops under General Browne. The successful passage of the Khyber, and the unopposed occupation, first of Dakka at the western mouth 
of the pass, and then of Jalālābād in the plains beyond, immediately followed. The treaty which closed the war in May, 1879, left the Khyber tribes for the future under British control. From that date the history of the Khyber Pass is bound up with that of the Khyber Political Agency, which includes Mullagori country north of the Khyber, Tīranh of the Afridis, and the country on both sides of the Khyber Pass. None of it is administered, but the pass is kept open and is picketed twice a week for the passage of caravans.

The Khyber Political Agency is bounded on the north Khyber by the Kābul river and the Safed Koh; on the east by Political Peshāwar District ; on the south by the Aka Khel and Orakzai countries; and on the west by the Chamkanni and Māsuzai countries, and the Safed Koh. The Khyber Pass between Jamrūd and Landi Kotal originally belonged to the Shinwāris, Zakka Khel, Kuki Khel, and the Orakzai only. At the time of the extension of Sikh rule to Jamrüd the Orakzai were ousted by the Afrīdis, and the only trace of their presence is a ruined village near Jam. The Sikh rule never extended beyond Jamrūd. When Colonel Mackeson was negotiating with the Afridis in r840, the Malikdin Khel Maliks of Chora forced their way between the Zakka Khel and Kuki Khel, and established a small village at Katta Kushta near Ali Masjid. The Sipah Kambar Khel and Kamrai Khel also, seeing the advantages of a footing in the Khyber, stepped in, and were admitted to a share in the Khyber allowance.

After the Sikh War the-Afridis took service in large numbers The in the Indian army, and when the Mutiny of 1857 broke out Afridis. they did exceedingly well. From 1857 to 1878 the Afridis were subsidized by the Afghān government, who kept a garrison of Afghān troops at Alī Masjid. The Afrīdis were, however, never on good terms with the Afghāns. They very often visited the British officers of Peshāwar District; but relations with them were maintained through the Khalil and Mohmand Arbābs of Peshāwar District, who were generally of an intriguing disposition, and very seldom did any real service. Their main object was to keep those tribes in a state of unrest, and thus enhance their own importance. A year or two before the second Afghān War Amīr Sher Alĩ summoned the jirgas of all the Afridis and Shinwāris, and distributed about 5,000 rifles to them. When war broke out, and $\mathrm{Ali}$ Masjid was attacked and turned, the Afghāns and Afridis fled in great disorder, and the Afghanns were robbed of their clothes and rifles by the Afrìdis in the Khyber and in Bāzār. The Afrīdis, and especially the 
Bāzār Zakka Khel, subsequently harassed the passage of the British troops through the Khyber, and a force was sent against them in December, 1878 .

British control.

Outbreak of 1897 .

By the Gandamak Treaty of 1879 between the British and Amir Yakūb Khān, it was agreed that the British Government should retain the control of the Khyber Pass; and, in pursuance of this agreement, allowances were fixed for the Afridis, aggregating Rs. 87,540 per annum. The management of the pass was entrusted to the tribesmen themselves through their Maliks, who executed a formal agreement by which they undertook to guard it with their tribesmen. Some local levies called jezailchis (which afterwards became the Khyber Rifles), numbering about 400 men, were also raised for escorting caravans through the Khyber. These were eventually increased to 600 strong.

In 1897 disturbances broke out all along the frontier. The Afrīdis remained quiet for some time, but in August they attacked the Khyber posts and sacked the fortified sarai at Landi Kotal. They met with opposition from the Khyber Rifles, but the garrison could not hold out owing to want of water. To punish the Afrīdis for this violation of their engagements, a force was sent into Tīrāh under Sir W. Lockhart, and a fine of Rs. 50,000 and 800 breech-loading rifles was recovered from them by April, 1898 . In October of the same year a fresh settlement was made with the Afrīdis, by which they undertook to have no intercourse with any power except the British, and to raise no objection to the construction of railways or roads through the Khyber. On these conditions the allowances were restored, with a small increase of Rs. 250 for the Kambar Khel. The Khyber Rifles were augmented to two battalions of 600 each, 50 of the total being mounted, and were placed under British officers.

Afrīdis.-A tribe of Pathāns inhabiting the mountainous country south of the KHYBER Pass, which is commonly called TínĀH. The chief subdivisions of the Afrîdi tribe are as follows :-

\begin{tabular}{|c|c|c|c|c|}
\hline $\begin{array}{c}\text { Section. } \\
\text { Kambar Khel }\end{array}$ & $\begin{array}{c}\text { Habitat. } \\
\text {. }\left\{\begin{array}{l}\text { Maidān, Bārā Valley } \\
\text { Kajūri Valley }\end{array} .\right.\end{array}$ & $\begin{array}{l}\text { Streng } \\
\} 4,500\end{array}$ & hhtir & $\begin{array}{l}\text { ated) } \\
\text { men. }\end{array}$ \\
\hline $\begin{array}{l}\text { Kamrai } \\
\text { Kuki Khel . }\end{array}$ & - $\left\{\begin{array}{l}\text { Bārā Valley } \\
\text { Khyber } \\
\text { Alĩ Masjid, Jamrūd }\end{array}\right.$ & $\begin{array}{r}600 \\
4,000\end{array}$ & $\begin{array}{l}\text { " } \\
\text { " }\end{array}$ & " \\
\hline $\begin{array}{l}\text { Malik Dīn Khel } \\
\text { Sepaiah (Sipāh) } \\
\text { Zakka Khel }\end{array}$ & $\begin{array}{l}\text { Mardān } \\
\text { Bārā Valley and Ka- } \\
\text { jūri Plain } \\
\text { Khyber, Bāzār, and } \\
\text { Bārā Valley . }\end{array}$ & $\begin{array}{l}1,200 \\
4,500\end{array}$ & " & " \\
\hline
\end{tabular}


Jamrūd.-Fort and cantonment just beyond the border of Peshāwar District, North-West Frontier Province, situated in $34^{\circ} \mathrm{N}$. and $7 \mathrm{I}^{\circ} 23^{\prime} \mathrm{E}$., at the mouth of the Khyber Pass, $\mathrm{r} \circ \frac{1}{2}$ miles west of Peshāwar. Population (r9or), r,848. Jamrūd was first fortified in 1836 by Hari Singh, the Sikh governor of Peshãwar. It is now the head-quarters of the Khyber Rifles, and is the collecting station for the Khyber tolls, and contains a considerable sarai. A large mobilization camping-ground has been selected 3 miles on the Peshāwar side of Jamrūd, and arrangements have been made for supplying water to it from the Bārā water-works. Jamrūd is connected with Peshãwar by a branch of the North-Western Railway.

Landi Kotal.-A post in the Khyber Pass, North-West Frontier Province, situated in $34^{\circ} 6^{\prime} \mathrm{N}$. and $7 \mathrm{r}^{\circ} 8^{\prime} \mathrm{E}$., and the westernmost point on that route occupied by the British Government. The kotal or pass crosses a small subsidiary watershed 3,600 feet above sea-level, and thence descends to the frontier of Afghānistān near Landi Khāna. In August, 1897, the post was attacked by the Afridis and carried, despite a stubborn defence by the Khyber Rifles. The fort is of the ordinary type, consisting of a keep and an outer fort with accommodation for 5 British officers and 500 native officers and men. Since 1899 it, like the other posts in the Khyber, has been garrisoned by the Khyber Rifles, an irregular corps of militia recruited from the tribes of the Khyber Agency.

Tîrāh.-A mountainous tract of unadministered territory in the North-West Frontier Province, lying between $33^{\circ} 37^{\prime}$ and $34^{\circ} \mathrm{N}$. and $70^{\circ} 30^{\prime}$ and $71^{\circ} 15^{\prime} \mathrm{E}$. It is inhabited in the summer months by all the sections of the Orakzai, two sections of the Jowāki Afridis, and by the Kulla Khel subsection of the Asho Khel sections of the Adam Khel Afridis. The name is also used in an extended sense to include almost the whole territory except the Bãzār and Khyber valleys inhabited by these tribes, the portions occupied by them in the winter months being distinguished as Lower Tīrāh. Tīrāh thus consists of the country watered by the Mastura, one of the main branches of the Bārā, which flows through the centre of the country, the Khānki Toi, and the Khurmāna-three rivers which rise within a few miles of Mittughar (12,470 feet), a point on the Safed Koh in $33^{\circ} 55^{\prime} \mathrm{N}$. and $70^{\circ} 37^{\prime} \mathrm{E}$.

At Mittughar the Safed Koh range splits up into several branches, between which lie the valleys of Tìrăh. The principal of these are the Rājgal, Maidān, and Warān, inhabited by Afrìdis ; and the upper portions of the Mastūra and Khānki 
Tois and of the Khurmanna Darra, which are occupied by the Orakzai. Of the various branches of the Safed Koh, the most northern runs due north from Mittughar for about 16 miles, and then divides into two spurs. One of these runs northward and, after throwing out to the east lesser spurs which enclose and form the Bāzār, Khyber, and Shilmān valleys, abuts on the Kābul river. The other, known as Surghar, runs eastward and, dividing the Bāzār and Chura valleys from that of Bārā, ends in the Peshāwar valley in the Kajūiri plain. A second branch runs south-east, dividing Afrìdi Tĩrāh from the Khurmāna Darra, and throwing out to the east two spurs, one of which divides the Rãjgal from the Maidãn valley, while the other, which divides Mastūra from Maidān in its prolongation eastwards, ends at Tānda Utmān Khel, where it meets the combined streams of Warān and Mastūra. At Srikando, a depression due north of this range, the valleys of Warân and Maidān are separated. The main spur known as the Saran Sar range ends abruptly at the junction of the two branches at So Toi or Maruāni, which is separated from the Kajūri plain by the Gandah Gallha.

Another range, the Sampagha, after throwing out a large spur which divides the Khānki Toi from the Khurmāna Darra, continues eastward, separating the Khānki Toi from the Mastūra valley, to the Mazighar peak $(7,940$ feet), where it turns sharply to the north to Landūkai and then again past Kohāt. The Zawa and Sāmāna range in its eastern extension ends at Shābu Khel, where it is cleft by the Khānki Toi, which runs east and west between the Khānki valley on one side and Mīrānzai on the other.

The valleys round the sources of the main rivers have an average elevation of 5,000 to $7,000 \mathrm{feet}$, and are buried in snow in winter, but afford abundant pasturage in summer. In winter, the climate of Tîrāh is intensely cold, except in the Bārā, Lower Mastūra, and Khānki valleys, which become hot and unhealthy later in the year. Elsewhere the summer climate is pleasant and healthy. The rainfall exceeds that of Peshāwar and Kohāt Districts. That on the Sāmāna averages 21 inches a year, and in the Khannki valley about the same, while in the Khurmāna and Upper Mastūra valleys it is greater, and in the Bārā and Lower Mastūra less.

The original inhabitants of Tĩrāh were the Tĩrāhis, probably a Tājik race, who were driven out of the country by the Pîr-iRoshan, 'the apostle of light'; and a remnant of them fled to Nangrahār. Soon afterwards, in 1619 or 1620 , Mahābat Khān, 
Sübahdār of Kābul under the emperor Jahāngir, treacherously massacred 300 Daulatzai Orakzai, who were Roshānia converts ; and, during his absence on a visit to Jahāngīr at Rohtās, Ghairat Khān was sent with a large force via Kohāt to invade Tĩräh. He advanced to the foot of the Sampagha pass, which was held by the Roshānias under Ihdād and the Daulatzai under Malik Tor. The Rājputs attacked the former and the latter were assailed by Ghairat Khān's own troops, but the Mughal forces were repulsed with great loss. Six years later, however, Muzaffar Khān, son of Khwāja Abdul Hasan, then Sübahdār of Kābul, marched against Ihdād by the Sugāwand pass and Gardez, and after five or six months' fighting Ihdād was shot and his head sent to Jahāngìr. His followers then took refuge in the Lowaghar; and subsequently Abdul Kādir, Ihdād's son, and his widow Alai, returned to Tîrāh. The death of Jahängir in 1627 was the signal for a general rising of the Afghāns against the Mughal domination. Muzaffar. Khān was attacked on his way from Peshāwar to Kābul, and severely handled by the Orakzai and Afrīdis, while Abdul Kādir attacked Peshāwar, plundered the city, and invested the citadel. Abdul Kādir was, however, compelled by the jealousy of the Afghāns to abandon the siege and retire to Tīrāh, whence he was induced to come into Peshāwar. There he died in 1635 . The Mughals sent a fresh expedition against his followers in Tîrāh; and Yūsuf, the Afrīdi, and Asār Mìr, the Orakzai chief, were at length induced to submit, and received lands at Pānippat near Delhi. Simultaneously operations were undertaken in Kurram. Yet, in spite of these measures, Mìr Yakūt, the imperial Dīwān at Peshāwar, was sent to Tĩrāh in 1658 to repress an Orakzai and Afrīdi revolt.

Since the decay of the Mughal empire Tĩrāh has been virtually independent, though owning at times a nominal allegiance to Kābul. Tĩrāh was first entered by a British force in 1897 , when the Orakzai and Afrīdis rose in jiha $\bar{d}$ or religious war against the British. The Orakzai attacked the Sāmāna, and the Afridis attacked Landi Kotal and the other posts in the Khyber Pass. These violations of British territory necessitated the dispatch of 34,500 men into Tìrāh, under the late Sir William Lockhart. The main body advanced from Shināwari in the Miranzai valley over the Chagur Kotal, the precipitous heights of Dargai near which, being held in force by the enemy, were gallantly stormed. The troops advanced across the Khānki and Mastūra valleys over the Sampāgha and Arhanga passes to Maidān and Bāzār, whence the whole of Tĩrāh was 
overrun, returning to Peshāwar by the Bārā valley in December. The names of the principal subdivisions of the two main tribes are given in the articles on AFridis and Orakzal.

Bāzār.-Valley in the Khyber Political Agency, North-West Frontier Province, running east and west between the Surghar range on the south, the Ilācha Ghar or eastern extension of the Safed Koh on the east, and the Turo Sar range to the north, between $33^{\circ} 38^{\prime}$ and $35^{\prime} \mathrm{N}$. and $70^{\circ} 37^{\prime}$ and $71^{\circ} \mathrm{E}$. Its elevation ranges from 3,000 to 4,000 feet, and that of the enclosing hills from 5,000 to 7,000 feet. The valley is sterile in the extreme, save where the village lands are irrigated from the hill streams. The people are Afridis of the notorious Zakka Khel or clan, the most active thieves on the frontier, against whom on three occasions punitive expeditions have been sent. In $\times 878$ their attacks on the line of communications in the Khyber during the second Afghān War compelled a punitive expedition. Major Cavagnari led an armed body of Kuki Khel Afridis, supported by guns, against them, and inflicted some punishment; but a regular expedition followed in December, which effectively chastised them at small cost of life. Nevertheless the clan continued to give trouble, and another expedition had to be sent into the valley in 1879 , after which the clan submitted. In 1897 two columns under Sir William Lockhart entered the valley by the Chora and Ilãcha passes at its eastern extremity, and destroyed the principal villages.

Orakzai.-A tribe of Pathāns inhabiting the north slopes of the Samāna range and the adjoining valleys of TíR̄̄H. The chief subdivisions of the Orakzai are as follows :-

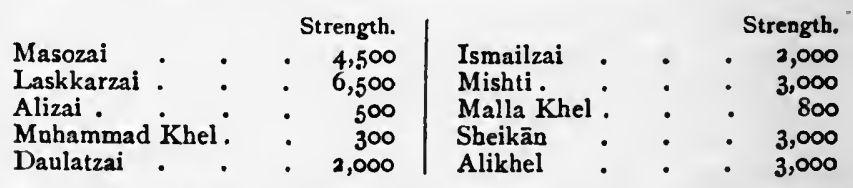

Boun- Kurram Agency (Kuram).-A Political Agency in the daries, con- North-West Frontier Province, lying between $33^{\circ} 19^{\prime}$ and and hill and river systems.

$34^{\circ} 3^{\prime} \mathrm{N}$. and $69^{\circ} 39^{\prime}$ and $70^{\circ} 28^{\prime}$ E., and comprising that section of the valley of the Kurram river which lies between the Peiwar Kotal in the west and the borders of Mīrānzai in the east. The Agency has an area of about $x, 278$ square miles, its maximum length from Thal to the Peiwar Kotal being 72 miles as the crow flies, and its breadth varying from 12 to 24 miles. Bounded on the north by the Safed Koh or 'White Mountain' (called in Pashtū the Spin Ghar), which separates 
it from Ningrahār, it adjoins Pāra-Chamkanni and the country of the Māssozai section of the Orakzai and that of the Zaimusht tribe on the east, its south-eastern corner abutting on the Mīrānzai country of Kohāt District. On the south it borders on Northern Waziristān; and on the south-west and west it is contiguous with the Afghān district of Khost, of which the Jāji Maidān or plain, the Chamkanni country, and Hariob Jāji lie on its western extremity.

The principal range in the Agency is the Safed Koh, the crest of which forms the watershed between the Surkhāb river or valley of Jalāābād and the Kurram. In this range the loftiest peak is Sikharām, I 5,620 feet above sea-level, which forms the extreme north-west corner of the Agency. From it the range runs almost due east, falling to 14,200 feet at Badni Sar, the peak above Zerān, and to 11,760 feet at the Agam pass, but rising again to 13 , oro feet at the peak above Khanrai in the north-eastern corner of the Agency. From Sikharām, a lower range, whose crest forms the western border of the Agency, and which is crowned by the Peiwar Kotal or pass, runs southwards, abutting on the Kurram river. On the south lies a lower and more irregular range, whose crest forms the boundary of Khost. Its highest peak, Khost Khoram, rises to 8,536 feet above the sea, but its mean elevation is only 5,000 feet, the Darwāzgai peak being 6,395 feet. From this range descends a spur through whose extremity the Kurram river appears to have cut a passage opposite Sadda, and which divides the valley into two parts, Upper and Lower Kurram. Upper Kurram is thus almost completely encircled by ranges of hills of very varying height, except where the Kurram river enters and leaves it. It is a wide open valley, mostly comprised in the sloping plain formed by the débris from the southern face of the Safed Koh, which descends to the Kurram river and is intersected by numerous streams. In this plain lie Părachinār, the headquarters, Shalozān, Kirmān, and most of the principal villages of the Agency. Above Pārachinār the valley attains a width of 15 miles. Lower Kurram is a narrow valley shut in by broken ranges of comparatively low elevation, though it widens to the south-east of Balyamin.

The only river in the Agency is the Kurram itself, which runs closer to its southern than to its northern border, especially in Upper Kurram. Rising in the hills near Ahmad Khel, it flows at first south-westward, and then turns sharply to the east, entering the Agency near Kharlāchi and thence flowing 
due east to Kurram Fort. East of that place its trend is somewhat southward; and at Sadda it turns sharply to the south until it reaches Maro Khel, whence it curves south-east as far as Thal, in Kohāt District. On the north it is fed by numerous streams, of which the principal are the Shalozān, Zerān, Kirmān, and Kurmāna; and on the south by several torrents, the Sarkalla, Minawar, and Taoda Shiga being the chief.

In Lower Kurram the scenery is dreary and barren, only relieved by the narrow strips of cultivation along the river banks ; but Upper Kurram is one of the most beautiful valleys in the Province, the encircling hills being well wooded and many of the villages picturesque, though the plain is for the most part as yet uncultivated and bare of trees. The climate also varies. In the winter even Lower Kurram is very cold and a bitter wind prevails, while in the summer it is hot and dry. Upper Kurram is never unpleasantly hot even in summer, while in winter snow covers the ground for weeks.

History. Legend says that the aborigines of Kurram were deos or demons who were ruled by their king the Safed Deo until the kingdom was overcome by two brothers, Shudāni and Budāni, from the north. Their descendants held sway for many centuries in Kurram, until they were in turn overwhelmed by invaders from the north. The authentic history of Kurram begins in 1148 , when Bahrām Shāh of Ghazni, after his defeat by Saif-ud-din of Ghor, fled to Kurram, whence he returned and recovered Ghazni. In $x_{1} 63$ Muhammad of Ghor was placed in charge of Istia and Kasri-Kajurān by Ghiyās-ud-dīn, Sultān of Ghor, his brother; and in $1176-7$ he conferred Sankurān (identified by Raverty with the modern Shalozān) and Kirmān on Tãj-ud-din Yalduz. It was at Kirmān that Muhammad of Ghor used to halt every year on his way into India. There too on his last expedition he conferred on Tãj-ud-din the black banner, thereby designating him his successor, and after his assassination his body was taken back to Ghazni through Kurram. Kirmān remained Tāj-ud-dīn's capital for a time, and to it he retreated after his defeat by Kutb-ud-din Aibak in 1206 . But in 1215 he was driven out of Kirmān by the Sultān Muhammad Khwarizm Shāh, who made over Ghor and Ghazni to his son Jalāl-ud-din Mankbarni. A few years later the tract was occupied by the Mongols.

In 1235 Saif-ud-din Hasan, Karlugh, gained possession of Ghazni, Kirmān, and Baniān (? Bannu), but was driven out of his territories by the Mongols in 1239 . After this Kurram disappears from history, until in $155^{2}$ Humâyūn, who then 
held Kābul, occupied it before his reconquest of India. Under Akbar it formed part of the toman of Bangash or the Bangashāt, being known as Upper Bangash to distinguish it from Lower Bangash, now Kohāt District. The Afghāns of this tract, called Karlārni Afghāns, were, as a body, disciples of the Pĩr-i-Roshan, and hence became known as Roshānias. These sectaries led the Afghān opposition to Mughal rule, and Kurram formed one of their chief strongholds. Although they were suppressed under Jahāngīr, the Mughals appear to have had little real control over Kurram, which was nominally governed, independently of Kābul, by the faujdārs of Bangash from Kohāt. On the break-up of the Mughal empire Kurram became part of the kingdom of Afghānistān; but in the meantime the Afghān tribes of Bangash had been overcome by the Türis, a tribe of Turkish origin belonging to the Shiah sect of Muhammadans, who speak Pashtũ and now rank as Pathāns. The Bangash tribes who remain in the valley are now hamsayyas or clients of the Türis.

After the annexation of Kohāt the Tūris, in league with other tribes, repeatedly harassed the Mìrānzai border, attacking the Bangash and Khattak villages in Kohāt. In I854 an agreement was made with them; but their raids continued, though punitive measures were not resorted to, as the tribe was held to be under the control of the Amīr of Afghannistān. Their raids increased in audacity, and in $185^{6}$ a force under Brigadier-General Neville Chamberlain entered the valley. Compensation, the payment of which was guaranteed by the Afghān governor Ghulām Jān, was exacted, the Tūris agreeing to pay Rs. 8,630. In 1859 the Türis joined the British expedition against the Kābul Khel Wazirs; but their feud with that tribe subsequently gave much trouble, reprisals being undertaken by Wazìrs in British territory for Türi outrages, and in 1876 serious disturbances arose between the Bangash of Lower Kurram and the British village of Thal out of a boundary dispute. In 1877 the Türis were discontented with the oppressive administration of Shāhbāz Khān, governor of Kurram ; and when the Amir demanded from them a contribution of Rs. 50,000 (a poll-tax of Rs. 5 on every adult male) and 6,000 recruits for his war against the British, they revolted and fled to the hills. Attempts to pacify the tribe were unsuccessful for a time, but the Türis at last agreed to send a jirga to ${ }^{\circ}$ ābul and pay a benefaction of Rs. 25,000, while Shāhbāz Khān was recalled by the Amīr.

In November, 1878 , a column under General Roberts 
entered Kurram from Thal, and occupied Kurram Fort on the $25^{\text {th }}$ of that month. On December 2 the Afghanns were defeated at the Peiwar Kotal, and on the 26th a British force marched from Kurram into Khost, which was occupied till the end of January. The conclusion of peace in May, 1879 , prevented further operations, until in September of that year, on the reopening of the war, General Roberts' force, which had remained in occupation of Kurram, again crossed the Shutargardan. The Türis now co-operated with the British expedition against the Zaimukhts, whose hostility had been marked by the murder of Lieutenant Kinloch; and Kurram was held without further disturbance till its evacuation in October, 1880. The Türis throughout furnished supplies, their levies were employed in escorting convoys, and they, with the Bangash, petitioned that the British should take over the valley and free them from Afghān rule; but it was determined to evacuate the country and the tribe was declared independent. Internal feuds broke out in a few months, and throughout $1882-4$ the Türis were constantly fighting among themselves, as well as with the Jajjis and Zaimukhts. The administration of the valley was finally undertaken by the British Government at the request of the Türis themselves in 1892 .

The people.

The Agency contains 166 villages besides Pārachinār, its head-quarters, and in rgor it had a population of $54,25 \%$. Administratively, it is divided into Upper and Lower Kurram. The bulk of the population is Pathān, nearly 44,000 , or 81 per cent., being of that race. The Türis, with nearly 12,000 , form the strongest element among the Pathān tribes; and next to them are the Bangash $(6,000)$, the Chamkannis, Ghilzai, Mangals, and Orakzai. The few Hindus are nearly all Aroras, that caste numbering nearly 2,000 . The language of the people is Pashtū, but Hindki is spoken by the resident Hindu population. Hindkī or Hindko is the Pashtū name for Western Punjābi as spoken by Hindus and some other people, e.g. the Peshāwar city folk, along the frontier. Agriculture is virtually the sole occupation of the people, as nothing but the most primitive industries are carried on; and all but the barest necessaries of life are imported into the valley. Silk, for which Kurram was in ancient times famous, is still produced and manufactured.

General agricultural conditions.

Wherever water is available for irrigation, the soil is highly productive; but owing to the absence of a settled government and the internal feuds of the people, the cultivable area is not all under cultivation, and irrigation is only carried on by small 
channels constructed and maintained by a single hamlet or family. Hitherto the autumn harvest of rice, maize, and oilseeds has been the more important, and it pays two-thirds of the land revenue; but the spring harvest of wheat, barley, and clover is of increasing value. Apples, pears, grapes, cherries, pomegranates, peaches, and a fruit peculiar to the Kurram and Tĩrāh, known as the shatill, also grow ; and with improved communications fruit-growing will probably become an important industry. Famine is unknown in Kurram.

Kurram is now accessible from Kohāt by the Khushālgarh-Means of Kohāt-Thal branch of the North-Western Railway. This does not enter the Agency, but a good tonga road runs from the terminus at Thal to Pārachinār ( 54 miles), crossing the Kirmān stream by a fine bridge. From Pārachinār the road is unmetalled and passes via Kharlāchi to Hariob. Unmetalled roads or bridle-paths also lead from Pārachinār to Peiwar, from Kharlāchi to Peiwar, from Mīr Jamāl to Uchadarra, and from Pārachinar to Walai China via Lakka Tigga. All were constructed in 1893 .

For administrative purposes the Agency is divided into Upper Adminisand Lower Kurram, each being under a naib-häkim, stationed trative at Pārachinār in Upper, and Sadda in Lower Kurram. The and staff. naib-häkims are under the control of the Political Agent, who is also aided by a Revenue Assistant.

The Indian Penal Code, the Criminal Procedure Code, the Civil Frontier Crimes Regulation, the Frontier Law and Justice justice Regulation, and the Murderous Outrages Regulation have been extended to Kurram, while Türizinna or the customary law of the Türis is enforced, all cases being settled by the Political Agent and his Assistants. The Turizuna, though unwritten, is well-known to the maliks or heads of tribes, and they decide what the custom is in any given case. The cases of a civil character are chiefly for the recovery of loans, possession of land, declaration of rights to water, questions of inheritance, possession of women, and disputes relating to revenue. Murder and violent crime are not very common, the chief offences being robbery and theft, especially of cattle, arson, mischief to fruit-trees, and abduction.

The rates of land revenue paid under Afghān rule varied from one to two rupees per jarib (about half an acre), but various other taxes were also levied. Thus the governor in I 886 fixed a poll-tax at Rs. $2-8$ on menials (barbers and Dums or minstrels), and at Rs. 3-8 on artisans and adult male Hindus. Each mill paid Rs. 3-8 a year, and dues were levied 
on all sales of ponies and cattle. These taxes were equal in amount to the land tax, and the valley was farmed for a total sum of a lakh.

Land The aim of the British Government was at first to carry on revenue. the revenue administration as far as possible on the Afghān system. A summary settlement was made in 1893-4, when the amount levied by the Afghān governors was ascertained and distributed in due proportion over individual holdings. The settlement was sanctioned for ten years; and including mälikāna on crown lands, revenue from mills, and taxes on artisans' shops (the latter being a substitute for the poll tax), the demand amounted to Rs. 67,300 (Kābuli). The all-round rates adopted were (in Kābuli currency) Rs. 3-5-0 per acre of cultivated land, Rs. 3-8-0 per mill, and Rs. 2-8-0 to Rs. 3 per artisan's shop. Cash payments or remissions of revenue amounting to about Rs. I9,000 were granted to leading men for political services or assistance in general administration, while smaller grants were sanctioned for the up-keep of shrines, rosques, temples, and especially mätim kotāhs or Shiahs' mourning houses.

No regular measurements were made, but the cultivated area was estimated roughly at 30,222 acres. A brief and incomplete record-of-rights was prepared, but some of the complicated tenures were left undecided, and no arrangements were made for keeping the record up to date. A few returns and statements were prescribed for maintaining a check on the collection of the land revenue and for lapsed assignments. Thus the revenue administration consisted of the collection of revenue, reassessment of estates subject to alluvial action, the maintenance of irrigation embankments, and harvest inspections in the crown lands. The revenue work is supervised by the Revenue Assistant, who is also Treasury officer. $\mathrm{He}$ is assisted by a mirāb (who looks after irrigation), 4 patuēaris, and a tahsil accountant. The resettlement of the valley began in r 904. It involves the conversion of the assessment from Käbuli into British rupees, and the preparation of a regular record-of-rights, including definitions of the different kinds of tenure, pedigree tables, irrigation customs, and maps of the cultivated land based on accurate measurements, and the reorganization of the revenue staff. The new demand is Rs. 71,500 British per annum, which in five years will rise to Rs. 88,000 .

Police and Police duties are performed by the Kurram militia, a force jails. I, 466 strong under a commandant. The lock-up at Pārachinār 
has accommodation for roo prisoners, and two lock-ups at Sadda and Alizai can each accommodate ro prisoners.

Kurram stands below all the Districts of the North-West Education. Frontier Province in the literacy of its population, only $\mathrm{r} .88$ per cent. ( 987 males and 25 females) being able to read and write in 1901 . It possesses seven indigenous schools, now aided by grants from Imperial funds, at Pārachinār and six of the principal villages, besides those in the mosques where the Korān and other religious books in Persian and Arabic are taught; in the dharmsälas the Hindus and Sikhs also learn the Granth and other religious books in Gurmukhi. Muhammadan girls are occasionally taught to read the Korān. The Bangash Pathāns of Shalozān are, however, mostly literate, and to their enlightenment is attributed the freedom from superstition which characterizes the rest of the valley.

There are two civil dispensaries, at Pārachinār and Alizai, Hospitals with accommodation for 12 male in-patients, and a female and disward for 4 in-patients at the former, besides two military hospitals. In 1903 the number of cases treated was 16,472 , of which 323 were in-patients. The expenditure was Rs. 4,763, met from Imperial funds.

A vaccinator is posted at Pārachinār, and in 1903-4 Vaccina1,708 persons were successfully vaccinated in the Agency.

Părachinăr.-Head-quarters of the Kurram Agency, NorthWest Frontier Province, situated in $33^{\circ} 52^{\prime} \mathrm{N}$. and $70^{\circ} 4^{\prime} \mathrm{E}$., I 7 miles west of Kohāt and 6 from the Peiwar Kotal, 3 miles from the southern slopes of the Safed Koh, in a plain naturally fertile but hitherto uncultivated owing to the absence of irrigation. Population (rgor), 2,847. Pārachinār possesses a temperate climate in which English flowers and fruit-trees grow well. The station was first occupied in 1893 , and is now the head-quarters of the Kurram militia and the residence of the Political Agent, Kurram. It contains a school, hospitals, and jail, but has no trade.

Sadda.-Post in the Kurram Agency, North-West Frontier Province, now garrisoned by a detachment of the Kurram militia. It lies in $33^{\circ} 30^{\prime} \mathrm{N}$. and $70^{\circ} 7^{\prime}$ E., on the left bank of the Kurram river. Under Afghān rule Sadda was the head-quarters of the governor of Kurram.

Waziristān, Northern.-A Political Agency in the NorthWest Frontier Province, lying between $32^{\circ} 45^{\prime}$ and $33^{\circ} 15^{\prime} \mathrm{N}$. and $69^{\circ} 30^{\prime}$ and $70^{\circ} 40^{\prime} \mathrm{E}$., with an area of about 2,3 10 square miles. It is bounded on the north and east by the Districts of Kohāt and Bannu, and on the south by the Shaktu stream, 
from the point where it enters the latter District to Shuidār at its head. From Shuidār the boundary follows the eastern watershed of the Shawall valley as far as Drenashtar Sar, and then runs north-east along the Durand Line to Kohisar in the country of the Kābul Khel Wazirs and Biland Khel. The Agency thus comprises four large and fertile valleys: in the north, the Lower Kurram valley between the Kurram Agency on the upper reaches of that river and Bannu District; the Kaitu valley; DAUR in the valley of the Tochi, the most open and fertile of the four; and the Khaisora valley in the south. Between the Kaitu and Tochi lie the Sheratulla and, north of Miram Shāh, the Dande-two barren plains, each about 30 square miles in area. Another plateau, called the Spererāgha, similar to the Sheratulla but smaller, lies between the Kurram and the Kaitu. With these exceptions, the valleys are separated by high barren hills. The loftiest peak is Shuidār (I I,000 feet), at the western end of the Khaisora valley. The hills are generally composed of eocene sandstone and conglomerate, through which great masses of limestone crop up, and their surface is covered with crumbling soil, which in flood-time fills the streams with the silt that fertilizes the valleys. The lowlands are feverish and unhealthy from August to October, and in the summer months the people migrate to the Shuidār highlands, which enjoy a perfect climate. With the exception of the Daurs of the Daur valley, the people of Northern IVaziristãn all belong to the Darwesh Khel branch of the Wazīrs, who are divided into two main sections, the Utmanzai and Ahmadzai. Both these sections are subdivided into numerous clans. The Darwesh Khel are perhaps the least tractable of the Pathān tribes, and their continued raids on the Daurs impelled the latter in 1894 to petition the British Government for protection. In consequence, Daur was taken over and is now under a form of direct administration, while the Wazirs are merely under political control. Under the agreement made with the Amìr of Afghannistān in 1893, the boundary of that State was demarcated in $1894-5$ without open opposition from the Darwesh Khel. Raids in British territory, however, continued, and in 1897 troops were sent from Datta Khel to enforce the collection of a fine which had been imposed on the village of Maizar. The villagers treacherously attacked this force, killing five British officers and men, and as a punishment their lands were laid waste by a military expedition. The tribe then submitted, and the Wazirs held aloof from the subsequent risings on the north-west frontier, 
though their raids continued. For some years the tract between Thal and the Tochi in the Lower Kurram valley inhabited by the Kābul Khel section of the Utmanzai remained a veritable Alsatia, in which a number of outlaws from British territory found a refuge. Finally, in November, I902, columns entered it from the Tochi, Bannu, and Thal. The tribesmen offered but little opposition, but at Gumatti a gang of outlaws made a desperate resistance. All towers were blown up and their rebuilding has not been pernitted. Large numbers of outlaws (about 250) surrendered themselves after the operations, and the country has since been opened by the tribe to the passage of troops and British officers. Roads have been made from Thal to Idak in the Tochi and to Bannu. Peace is now kept in the Tochi valley, the only portion of the Agency which is administered, by a militia corps of $\mathrm{I}, 3 \mathrm{I} 8 \mathrm{men}$, of whom 106 are mounted, the regular troops having been withdrawn in 1904 .

Boya.-Village in the Daur valley in the Northern Waziristān Agency, North-West Frontier Province, lying in $32^{\circ} 57^{\prime} \mathrm{N}$. and $69^{\circ} 57^{\prime} \mathrm{E}$., on the right bank of the Tochi river at an elevation of 3,600 feet. It contains 62 houses of the Boya Khel Tappizād Dauris, and is garrisoned by the Northern IVazīristān militia.

Idak.-Village in the Daur valley, in the Northern Wazĩristān Agency, North-West Frontier Province, lying in $32^{\circ} 57^{\prime} \mathrm{N}$. and $70^{\circ}$ I $5^{\prime} \mathrm{E}$., on the left bank of the Tochi river, 28 miles west of Bannu. Its inhabitants belong to the Idak subdivision of the Tappizād Dauris. About $\mathbf{r} \frac{1}{2}$ miles north-east of the village is a post garrisoned by the Northern Waziristān militia.

Miram Shāh (Mīrān Shāhh).-Head-quarters of the Northern Wazīristān Agency, North-West Frontier Province, situated in $33^{\circ} 57^{\prime} \mathrm{N}$. and $70^{\prime} 7^{\prime}$ E., in Daur (the Tochi valley), about 57 miles west of Bannu. Its elevation is 3,050 feet above the sea, and it comprises three or four hamlets. It is now garrisoned by the Northern Waziristān militia.

Maizar.-Village on the southern bank of the Margha river in the Madda Khel territory, Northern Wazīistān Agency, NorthWest Frontier Province, situated in $32^{\circ} 54^{\prime}$ N. and $69^{\circ} 37^{\prime}$ E. On June 10, 1897 , the Madda Khels treacherously attacked the Political officer's escort, and shot down several British officers and sepoys of the force under the walls of the village. A punitive expedition was dispatched, which exacted a fine of Rs. 10,000, besides Rs. 9,000 as compensation for the property taken in the attack, and the surrender of six of the ringleaders. 
Daur.-Valley in the Northern Waziristān Agency, NorthWest Frontier Province, lying between $32^{\circ} 50^{\prime}$ and $33^{\circ} \mathrm{N}$. and $69^{\circ} 55^{\prime}$ and $70^{\circ} 25^{\prime} \mathrm{E}$. The valley lies on the banks of the Tochi, extending from the point where that river leaves the Wazir hills to where it re-enters them near Khajuri, about I $_{5}$ miles from the western border of Bannu District. Daur is thus entirely surrounded by the Wazir hills, the highest peak in it being Vezhda $(7,700$ feet). Its length is 35 miles and its breadth averages $\mathrm{I} \frac{1}{2}$ miles, but it widens to 5 or 6 miles at its broadest part. The protected area, which extends to the crests of the hills nearest the river on both banks, measures about 700 square miles. Like most frontier valleys, it is divided into Lar or Lower and Bar or Upper Daur, the former comprising the larger area. The climate is bracing and healthy in the cold season, but feverish and unhealthy in the hot months, especially in August and September. The annual rainfall probably exceeds 15 inches.

Of the ancient history of Daur nothing is known. A mound near Idak is said to mark the site of its ancient capital. In I 700 Bahādur Shāh, then viceroy of Kābul, passed through the valley on his way from Khost to Bannu after effecting an arrangement with the tribes; but on his return in the following year his forces were repulsed, and he was compelled to pay heavy sums to secure an unopposed passage. Eventually Daur fell nominally under Durrāni rule; but it remained virtually independent till 1893 , when by the treaty with the Amīr of Afghānistān it came within the British sphere of influence, the actual boundary being demarcated in 1895 . While the Demarcation Commissioner was in Daur, the people petitioned that the whole valley should be taken over by the British Government, in order to protect them against the raids of their neighbours, the Wazīrs and Mahsūds.

Daur contains about 75 walled hamlets. Its resident population in 1903 was 24,670 . These are mostly Dauris, a race of 'gross satyr-like spadesmen,' morally the lowest of the Afghān races. Other Afghān tribes despise the Dauris, whom they describe as the progeny of a Bannuchi father and a Dum or low-caste mother. The Dauris are diligent, hardworking, and patient cultivators, developed physically by the use of the spade, the plough being useless in the heavy alluvial soil of the valley; but though fanatical, they are unwarlike. Their neighbours, despite frequent efforts, were never able to oust them from their valley, though the Wazirs have established small settlements wherever they could get a foothold, and hold 
a large area in proportion to their numbers. Of the resident population $2 \mathrm{I}, 000$ are agriculturists and entirely dependent on the soil, the pressure on which is heavy.

The lands of the valley are extremely rich, and grow heavy crops of maize, rice, millet, sugar-cane, wheat, and barley. The growth of trees is only now beginning, but promises well. Mulberry, chinār, willow, and fruit trees do best. There is a fairly extensive weaving industry, for which cotton is imported. The cultivated area is 15,262 acres, or about fiveeighths of an acre per head of population. Tenants cultivate about one-third of this area and pay heavy rents in kind, two-thirds of the gross produce being the usual amount. Daur used to be celebrated for its horses, but the breed is now extinct. Goats and sheep find good grazing in the neighbouring hills, despite their barren appearance.

The system of irrigation is that common in the Afghān hills, being carried on by means of channels cut from the Tochi river and its tributary torrents. These watercourses are so well designed that the cultivated area in Daur proper is hardly capable of great extension, though flood-channels which would carry the fertilizing flood-waters of the Tochi to the higher lands are feasible, and will greatly improve the quality of a large area.

The principal customers of the Dauris are the surrounding Wazir tribes, to whom the surplus produce of the valley is sold. It has no other trade.

Daur is under the Political Agent, Northern Wazīistān, who is assisted by a tahsildär and three naib-tahsildärs. The Indian Penal Code and the Code of Criminal Procedure, and also Regulations III and IV and VII of 1901 , are in force in Daur; but as a rule Muhammadan law modified by local customs is administered. The principle underlying these customs is the usual Pathān claim of 'an eye for an eye, and a tooth for a tooth'; but every Dauri has his price, whereby his wounds or pride may be salved, and for most offences a fixed sum is laid down by paying which an offender may pacify the party he has injured. In practice, however, the amount actually paid depends on the strength and influence of the opposing parties, and the weaker usually goes to the wall. As a rule, a Hindu or a woman counts as half a man. Intention is not regarded, only the result, so that accidental homicide incurs all the penalties of murder. The blood feud flourishes, and is regulated by a short and simple unwritten code. There is a regular tariff for bodily injuries, and theft is punished by a fine. 
Under the terms of their petition of 1895 , the Dauris agreed to pay a tithe of the gross produce to the British Government. For eight years this tithe was commuted into a payment of Rs. 8,000, levied by means of a house-tax; but in 1903 a revenue settlement of the valley was made, a record-of-rights being drawn up and the tithe assessed at Rs. 36,000. In addition, a shop and artisan tax of Rs. 1,500 is levied, raising the total revenue of the valley to Rs. 37,500 . This assessment has been sanctioned for ten years from the autumn of 1903 , with the proviso that if any considerable number of villages desire to pay in kind, they shall be permitted to do so.

Government schools have been established at Miram Shāh, Idak, Hassū Khel, and Tappi.

Boun- Waziristān, Southern. - A Political Agency in the Northdaries, con- West Frontier Province, lying between $31^{\circ} 55^{\prime}$ and $32^{\circ} 45^{\prime} \mathrm{N}$. and hill and $69^{\circ} 20^{\prime}$ and $70^{\circ} 15^{\prime} \mathrm{E}$., with an area of about 2,734 square and river systems. miles. It is bordered on the north by the range which terminates in the Ghalimighar and divides it from Northern Waziristān, while on the east its boundary runs due south along a continuation of the Bābaghar range to Jandola, whence it rises to the Girni Sar and then descends to the valley of the Gomal river above Murtazā. On the south as far as Kajuri Kach in the Gomal valley it is separated from the Shirãni country by the hills south of the Gomal river, the highest of which is the famous Takht-i-Sulaimann. West of Kajuri Kach the Gomal is the boundary between the Agency and the Baluchistann District of Zhob. On the west it extends to the Durand Line, demarcated in 1894 .

The Agency includes all the country occupied by the Mahsūd branch of Wazirs, and, on the west, portions of the country of the Darwesh Khel Wazirs. The whole area is mountainous in the extreme, the chief peaks bẹing Shuidār (I I, ,oo), Jānimela $(8,400)$, Pīr Ghal (1 I, 600$)$, Kundighar $(8,100)$, Girni Sar $(5,800)$, Drenashtar Narai $(8,750)$, Momin (10,800), and Sarwar Gul $(10,700)$. The last two are in the Marwattai range which runs along the Afghān border.

The outer spurs of the Wazir hills are to the eye utterly barren and desolate, though here and there the scanty soil nourishes a few stunted wild olive and gurgurra bushes. These hills, however, afford good grazing for goats. The inner hills with their greater elevation are more thickly wooded with ilex and pine, and the grassy uplands are dotted in places with wild flowers. To the south-west the aspect of the country changes into wide open plains, which from a distance look like rolling 
grassy pampas, but are covered with stones and boulders and scored by waterless ravines. The chief plains are Zarmelān north-east of Domandi, Wānā, and Spīn.

The only river worthy of the name in Southern Waziristān is the Gomal, which has a strong current, with a depth of 2 to 20 feet, and a width of 20 to roo yards, even in times of drought. Entering British territory at Domandi in the southwest corner of the Agency, it flows almost due east along its southern border, receiving numerous tributaries on its left bank, but only one, the Zhob, of any importance on its right. It then breaks through the Sulaimān range and debouches on the Derajāt plains near Murtazā. The only other perennial streams are the Tānk Zām and its tributary the Shahür, which drain the whole Mahsūd country; and the Wānā Toi, which rises at the head of the Dhana valley and falls into the Gomal at Toi Khulla. The others are mere torrents, dangerous after heavy rainfall, but dry at most seasons of the year.

Ilex, deodār, edible and blue pines are the only timber trees, Flora. but these grow abundantly on the mountains above 7,000 feet. The dwarf-palm grows freely in places and is used to make mats. The seed of the edible pine-cones, walnuts, apricots, and gurgurra berries are the only common fruits, but on the Spera range the wild pistachio is found. Grass is abundant on the higher ranges, and shrubs such as the acacia (palosi) and wild olive (khawan) in the valleys.

Straight-horned mārkhor and uriāl are to be found in many Fauna. of the higher hills, and 'ravine deer' in the valley and in the Wānā plains. The Greek partridge, sisì, bustard, and a few black partridge and pigeon are the chief game birds, and the coronetted sand-grouse breeds in the Wānā plain, where duck and snipe are also found. A fine breed of sheep dogs, resembling the Scotch collie, is kept by the Wazirs. Bears, leopards, wolves, and hyenas are found in the more inaccessible hills, the two latter only visiting the valleys in winter. The streams contain mahseer and other kinds of fish.

The climate is dry and in the winter months bracing, but Climate. from July to September there are constant thunderstorms. Though the country is beyond the reach of the regular monsoon rains, the resulting dampness renders the climate of the lower valleys, especially the Gomal, enervating and unhealthy. The autumn is usually rainless until December, when rain or (above 4,000 feet) snow and hail fall, and in January and February the snowfall is fairly heavy. The temperature in spring, even in the lower valleys, is very pleasant; but as 
summer approaches the heat becomes excessive, being aggravated by the barrenness of the rocky gorges. The water-supply is scanty. The water of the Gomal is slightly saline, while that of the Zhob is too brackish to be drunk. The upper ranges have a pleasant climate; and such places as the Sarūna plateau near Băbaghar, the upper slopes of the Marwatti range, and notably the beautiful upland valley of Zindāwar near Baghar China, possess every climatic advantage over the lowlands and valleys in summer.

History. The Mahsūds were formerly notorious as the most inveterate raiders on the north-west frontier; and in 1860 a long series of outrages culminated in an attempt to sack the town of Tānk in Dera Ismail Khān District, which was frustrated by Resaldār Saādat Khān in command of a detachment of the $5^{\text {th Punjab }}$ Cavalry. This was followed by a punitive expedition under Brigadier-General Chamberlain which, in the same year, advanced to Kaniguram and inflicted great loss on the tribe, but did not secure its submission. The raids continued; and though in 1863 the Mahsūds entered into an agreement to keep the peace it was promptly broken, while in 1878 they advanced, 2,000 or 3,000 strong, on Tānk and burnt the town. This incident was the signal for an outbreak of violence, in which several villages were burnt by the lawless tribes on the border, and which was only suppressed after severe fighting. In I 88I a second punitive expedition invaded the Mahsūd country and again penetrated to Kaniguram, but failed to exact compliance with the conditions imposed by the British Government, and the blockade was continued until hostages were given and the compensation due from the tribe was gradually realized by a tax on all their exports into British territory. From 188I to I 89 I the conduct of the Mahsūds was satisfactory; and in $1889 \mathrm{Sir} R$. Sandeman succeeded in opening up the Gomal Pass, nearly Rs. 50,000 in annual allowances being paid to the Malsūds in return for their guarding it. The Ahmadzai Wazīrs of Wāna also received allowances. In 1892 the Amîr of Afghānistān made attempts to obtain control of Wazīistān, and in the summer of that year numerous offences were committed in British territory. Troops were then advanced to Jandola and Kajuri Kach; and the Amïr's agents having withdrawn, affairs settled down again until the garrisons were reduced, whereupon raiding began again in the Gomal and Zhob valleys, and in June, r893, a British official was murdered. The murderers were surrendered, but two of the maliks who handed them over were in turn assassinated. During 1893 the 
Amīr renounced all claims to Wazīristān, and in 1894 a British Commission was appointed to demarcate the boundary from Domandi northwards. Meanwhile, the Wazīr outrages had not ceased, and the British Government resolved to accept the invitation of Ahmadzai Darwesh Khel of Wānā to occupy their territory, thereby hoping to secure the peace of the Gomal Pass. Spin and Wānā were declared protected areas ; but the escort encamped at the latter place was attacked by the Mahsūds under the Mullā Powinda, a religious leader, who had assumed the title of $B \bar{a} d s h \vec{a} h-\bar{i}-T a \bar{a} l i b \bar{a}$, or ' King of the Seekers-(after knowledge),' and acquired great influence over the Mahsūds. A third punitive expedition was dispatched in the cold season of $1894-5$ under Sir W. Lockhart, whose columns overran the Mahsūd country, and severely punished the sections of the tribes which had been implicated in the attack on Wānā. The boundary with Afghānistān was then finally demarcated; and in 1896 Southern Wazīistān was constituted a Political Agency under a Political Agent subordinate to the Commissioner of the Derajāt, with head-quarters at Wānā. During $1896-7$ affairs were quiet in the Agency, and it was the only portion of the north-west frontier which did not share in the general rising of $1897-8$. But between July, 1898 , and the end of 1899 , numerous outrages occurred and, though a conciliatory policy was adopted, the outrages continued, until in rgoo the Mahsūds were strictly blockaded. The British Government was eventually able to treat with a full tribal jirga capable of enforcing its decrees on the whole community, and the terms imposed by Government were accepted by it. The Darwesh Khel have at no time given trouble, and since the blockade the Mahsūds have refrained from raiding in British territory. This has rendered possible the withdrawal of the regular troops; and except at Jandola, where there are two companies of regulars, the only force now maintained for the safeguarding of the protected area is the Southern Waziristān militia, 1,576 strong, including $\mathrm{r} 59$ mounted men.

The dominant tribe of Southern Waziristān is the Wazīrs, The who are divided into two main branches, the Darwesh Khel people. and the Mahsūds. Migrating from Birmal at the close of the fourteenth century they occupied Shawāl and the Kohāt border north of the Tochi, which river they subsequently crossed, and from the hill country round Shuidār gradually spread southwards to the Gomal. The two branches of the Wazirs are now at feud. Other elements in the population are the Ghilzai Powindas, of whom the Dotanni clan has settled at Spin and 
Wanna; the Hindus; and the Saiyids and Urmars of Kaniguram. The Wazirs speak a very broad dialect of Pashtū, with curious modifications of the vowels. For instance, 'Hindu' is pronounced 'Indī.' Their vocabulary contains a few Punjābi words thus disguised ${ }^{1}$.

Tribal The Wazirs do not in theory carry out a blood feud to its customs. bitter end as do other Pathāns, for the death of the offender generally extinguishes the feud; but if he escapes, the life of a relation may be taken, and as this may be in turn avenged, the feud tends to become interminable, as it is among the Afridis. On the other hand, a murder may be compounded, but only on payment of a heavier sum than is usual among Pathāns, Rs. 650 being the fixed amount. Professional assassins are often employed to punish a murderer, the hire being from Rs. 60 to 150 , which is also the price of a bride. The people are by instinct intensely democratic, and any man may rise by courage and wisdom to the position of malik or leader; but these maliks have often little influence and no real authority, and many who have attempted an untoward assumption of it have been assassinated.

Agricul- Though the lands which lie close to the numerous streams ture. are well cultivated, their extent is insufficient to produce grain for the whole population. Wheat, barley, rice, maize, and millet are the chief crops, and these are often cut when green for fodder, springing up again before the harvest. Potatoes, introduced fifty years ago, are cultivated around Kaniguran.

The kine are small, black, nimble creatures, and are in much better condition than is usual in India. Goats are numerous, as are sheep, all of the fat-tailed variety; but none are sold, as they only suffice for local requirements.

A stretch of alluvial land beside a river-bed is called a kach in Waziri Pashtū; and in the valleys and kachs the land is generally terraced and irrigated by channels cut out of the hill-side, often with considerable labour and engineering skill.

Mines and The chief mineral product is iron, which is found and minerals. smelted in many places, especially in the hills above Makin, one of the chief strongholds of the Mahsüds.

Arts and Iron is made into knives and utensils, and was formerly made manufactures. into jazails, or matchlocks, at Kaniguram. The artisans are almost all of the Nazar Khel, a section of the Mahsūds. Mats and ropes are made of the dwarf-palm by the men, and the women weave rough cloth from wool and blankets from goats'

1 J. G. Lorimer, Grammar and Vocabulary of Wazìri Pashtū, Calcutta, 1902. 
hair. The Dotanni Ghilzai Powindas of Dotanni Kot near Wānā are carpenters, goldsmiths, and leather-workers.

Apart from the carrying trade throughout the Gomal valley, Commerce which is in the hands of the Powindas, the exports of Southern and trade. Waziristān consist of timber and firewood, mats and ropes, hides, and $g h \bar{i}$, which are carried down by the Wazìrs to Tānk, Bannu, and Kālābagh on the Indus, piece-goods, grain, and raw sugar being brought back in exchange.

Wānā.-A wide open valley, containing the Wānā post, the head-quarters of the Southern Wazīistān Agency, NorthWest Frontier Province, lying in $37^{\circ} 18^{\prime} \mathrm{N}$. and $69^{\circ} 44^{\prime} \mathrm{E}$. The valley is 12 miles long by 8 broad, lying west of the Mahsūd highlands, from which it is separated by the Janimela group of mountains. The elevation of the valley varies from 5,780 to 4,300 feet, and it forms a stony plain intersected by many torrents, the principal being the Dhāna, which is called the Wāna Toi on entering the plain. Most of the water flowing down these channels is used for irrigation, the land along the Toi being extensively cultivated and yielding good crops. The plain is chiefly inhabited by Wazirs, but its former inhabitants, the Ghilzai Powindas, still hold the large village of Dotanni Kot. In 1894 Wānā was the scene of the attack by the Mahsūds under the Mulla Powinda on the British delimitation escort under Brigadier-General A. H. Turner, which resulted in the repulse of the Mahsüds with a loss of $35^{\circ}$ killed and 700 wounded, the British loss being 45 killed and 75 wounded.

Gomal Pass (Gumal). - The route which leads along the valley of the Gomal river, through the Southern Waziristān Agency, North-West Frontier Province, from Murtazā and Domandi, on the borders of Afghānistān and Baluchistān, to the Afghān plateau. The Gomal is the oldest of all the trade routes in this quarter. Down it there pours yearly a succession of käfilas or caravans led and followed by thousands of well-armed traders, called Powindas, from Afghānistān to India. These traders belong to the Ghilzai race, of which the chief tribes are the Dotannis, Sulaimān Khel, Nāsirs, Kharotis, Jandrān, \&c.

Mahsūds.-The country of the Mahsūds lies in the south of Wazīristān, North-West Frontier Province. It is hemmed in on the north and west by the Utmanzai Darwesh Khels, on the south-west by the Ahmadzai of Wānā, and on the east by the Bhittannis. On the south of the Mahsund country a tract on both the north and south side of the Gomal Pass is devoid 
of permanent inhabitants. The permanent neighbours of the Mahsūds in this direction are the Shirānis, whose country lies south of the tract referred to. The Mahsund country hardly comes in contact with British India; all the passes from it which debouch on to British territory pass through the country of the Bhittannis. The Gomal Pass is the sole exception to this rule, and several routes lead from it to the Mahsund country. This pass has always been considered as belonging to the Mahsūds, though actually it is outside the limits of their country. The Mahsunds renounced their claim to raid in the pass, and undertook to keep it safe in consideration of the allowances and service granted in the beginning of $r 890$ at Apozai (Fort Sandeman), which were revised after the attack made by them on the Delimitation Commission at Wānā in November, 1894 .

The Mahsūd country is a tangled mass of mountains and hills of every size, shape, and bearing, and is intersected in all directions by ravines generally flanked through their course by high hills. At first sight the whole country appears to be occupied by hills and mountains running irregularly in all directions, but there are well-defined ranges which protect the interior of the country by double barriers, and make penetration into it a matter of extreme difficulty.

The Mahsūds claim descent from Mahsūd, son of Mahmūd, son of Khizri, son of Wazir, and are divided into three main branches : namely, Alizzai, Shāman Khel, and Bahlolzai, each of which is subdivided into countless sections and sub-sections. The fighting strength of the three branches is estimated atAlizai, 4,042 ; Shāman Khel (including Urmars), 2,466; and Bahlolzai, 4,088: a total of 10,596. Notwithstanding the differences in their fighting strengths, the three branches divide the tribal profits and liabilities into three equal shares among themselves.

The Punjab Government described the Mahsūds in r88I as follows :-

'Notorious as the boldest of robbers, they are more worthily admired for the courage which they show in attack and in hand-to-hand fighting with the sword. From the early days of British rule in the Punjab few tribes on the frontier have given greater or more continuous trouble, and none have been more daring or more persistent in disturbing the peace of British territory. It is no exaggeration to say that for the first twenty years after annexation not a month passed without some serious crimes, such as cattle-lifting, robbery accompanied by murder, being committed by armed bands of marauders from the Mahsūd hills.' 
The description is still applicable, though the behaviour of the tribe has been good since the blockade of $190 \mathrm{r}$.

The redistribution of the allowances granted to the tribe in 1895 , after the close of the Mahsūd expedition, was made with special reference to the reorganization of the whole scheme of maliks. The principle which underlies the new arrangement was that the power and influence of a limited number of leading maliks in the tribe, and more particularly in their respective sections, should be enhanced by every possible means, so as in the first place to enable them to control their respective sections as effectively as possible, and secondly to enable Government to deal with a definite number of tribal representatives. The plan broke down completely, for Government was unable to protect the maliks, and the maliks consequently were reluctant to exert such authority as they had. The state of the border went from bad to worse between 1895 and 1900 , when the tribe was put under strict blockade. This resulted in the submission of the tribe in Igor, when a complete redistribution of allowances was made. The tribe has since restrained its young men from raiding; but fanatical murders by Mahsūds, which were previously unknown, have given them an unenviable notoriety.

Bhittanni.-A tribe inhabiting the borders of Dera Ismail Khān and Bannu Districts, North-West Frontier Province, dwelling partly in independent territory and partly in British India. The Bhittanni country lies between the Derajāt and Mahsūd territory. The area occupied by independent Bhittannis is about 15 miles wide and 25 miles long, extending from Spinghar and Jandola on the west to the foot of the hills at the Bain pass on the east, and from the Gabarghar on the north to Girni Sar on the south. Three-fourths of the tribe, which numbers between 5,000 and 6,000 fighting-men, are at present revenue-paying British subjects.

The independent Bhittannis are politically controlled by the Deputy-Commissioner of Dera Ismail Khān. They are the hereditary enemies of the Mahsūds, although they have more than once forgone their time-honoured feud, and either combined with, or aided and abetted, their more rapacious neighbours in attacks and raids in British territory. Now, however, they have practically become identified as a tribe with British interests, and they furnish valuable material for a company of the South Wazïristān militia corps.

In appearance the Bhittannis are not so rough as the Mahsūds, though in physique they closely resemble them: 
they have discarded the dress of their neighbours of the Waziristann highlands for the more civilized apparel of the daman, and present a much cleaner appearance. Their pronunciation resembles that of the Mahsūds, but they have a curious trick of misplacing aspirates, which are in general correctly sounded by their neighbours.

Their country consists, beyond the administrative border, of rough stony hills scored by deep valleys, along which there is a little cultivation here and there, where the inhabitants have been able to lead the rather intermittent water-supply of the nullahs on to the cultivable lowland by irrigation channels. The Bhittanni hills are extremely rough and almost devoid of verdure, their rugged and barren character being probably due to the denuding action of rain and sun on the friable soil of these outer ranges.

Jandola (Jandula). - A Bhittanni village on the right-hand bank of the Tānk Zām stream on the borders of the Mahsūd territory in the Southern Wazīistān Political Agency, NorthWest Frontier Province, situated in $32^{\circ} 20^{\prime}$ N. and $70^{\circ} 9^{\prime} \mathrm{E}$. A fortified post close to the village is garrisoned by 2 companies of regulars and 25 cavalry, besides the Bhittanni levies.

Shirāni Country.-A tract on the western border of Dera Ismail Khān District, North-West Frontier Province, lying between $31^{\circ} 30^{\prime}$ and $32^{\circ} \mathrm{N}$. and $69^{\circ} 45^{\prime}$ and $70^{\circ} 20^{\prime} \mathrm{E}$. It is bordered on the north by Waziristān, on the west by Baluchistān, and on the south by the Usterāna Afghāns. The Sulaimann range, running from north to south, divides the country into two parts, Largha or 'lowland,' and Bargha or 'highland.' The former had a population of r $2,37 \mathrm{I}$ in r $\mathrm{r} 0 \mathrm{r}$, and is under the political control of the North-West Frontier Province; the latter is under that of Baluchistān. The Largha Shirāni country is administered by an Extra Assistant Commissioner with head-quarters at Drazinda, acting under the general supervision of the Deputy-Commissioner of Dera Ismail Khān. The country is poor, the lowlanders being dependent on agriculture, while the Bar Shirānis lead a pastoral life on the higher slopes of the Takht-i-Sulaimān, to which the flocks and herds of both sections are sent in summer. The higher hills are covered with forests of the chilgoza (Pinus gerardiana), in which each section of the tribe has a recognized share, and the profits from the sale of the fruit form a considerable item in their income. The Shirānis are Afghāns, and intensely democratic, though each section has a nominal chief or neka. Tribal cohesion is weak. Before 
annexation the Shirānis had been the terror of the frontier, carrying off cattle and men and women, whom they held to ransom. They sacked Draband, which was held by a small Sikh garrison, and by 1848 had laid waste the border for miles. In 1853 a British expedition sent against the tribe secured their submission, but in 1890 a force had to be sent to coerce the Khiddarzai clan.

In 1899 an agreement was concluded with the tribe, whereby they agreed to pay Rs. 2,000 as revenue, and the British undertook the internal administration of the country. This waś carried on successfully until 1902, when the Extra Assistant Commissioner was murdered by a jamadār in the Shirāni levies. The murderer was joined by thirty or forty malcontents, mostly from the Khiddarzai section of the Oba Khel, and for some months evaded a military force in the higher ranges of the Takht-i-Sulaimān. He finally made good his escape to Afghānistān with his gang, whence they come raiding from time to time.

Takht-i-Sulaimān ('Solomon's throne'). -A shrine (ziārat) on the mountain of the Sulaimān range, North-West Frontier Province, known as the Kaisargarh or Kasi Ghar, but usually called by Europeans the Takht-i-Sulaimān, situated in $3 \mathrm{I}^{\circ} 4 \mathrm{I}^{\prime} \mathrm{N}$. and $70^{\circ}$ E., at an elevation of I I,295 feet above the sea-level. Tradition says that Solomon halted on a ledge some distance below the crest on the southernmost bluff of the Kaisargarh to take a last look over India, whence he was carrying off an Indian bride to Jerusalem. The shrine marks the spot. The takht, which was attempted by members of Elphinstone's mission to Kābul in 1809 , was first climbed by a European in 1883 .

[T. Holdich, The Indian Borderland, chap. iv (r90r).] 



\section{N D E X}

A.

Abāzai, fort (1852) and village in Peshāwar District, on the bank of the Swāt river, here 150 yards broad, I60; its ferry the highest in British territory, I6I.

Abbott, Major James, first Deputy-Commissioner (1 847-53) of Hazāra, I39; his firm and wise rule before and dnring the second Sikh War, I 29; his land settlement, I 35 .

Abbottābād, well - timbered tahsīl of Hazāra District, 137 .

Abbottābād town, head-quarters of Hazära District and tahsil, 139 , named after first Deputy-Commissioner, I 39 ; a municipality and a cantonment, 139 , their finance, 139 .

Abdul Ghafür, the famons Akhund of Swāt (1835-77), or leader of fanatical sect, 20, 21 8, 219, 221 ; Ambela campaign against, 20, $21,224,225$. See also Akhund.

Adamzādas, one of the two upper classes or tribes of Chitrāl, 211, 213, joined Umrā Khān in the siege (1895) of Chitrāl, 2 I 2.

Administration, 57-61 ; under the control of a Chief Commissioner, 57 , also in political areas Agent to the GovernorGeneral of India, 57, 59; his staff, and a list of the high officials of the Province, $57,5^{8}$; the five Districts, each under a Deputy-Commissioner and his staff, 58 ; subdivisions, each in charge of an Assistant or Extra Assistant Commissioner, 58 ; the sub-collectorates or tahsils, each in charge of a tahsildar and a naib-tahsīldār, 58, känungos, patwāris (acconntants), village headmen, chaukidärs or village watchmen, 58; Political Agencies, 59; legislation and justice, $59-6 \mathrm{r}$.

Afghānistān, trade with, 52,53 , throngh Peshāwar, 153, 166, by Gomal Pass, 53, 208, its increase since (I901) partial removal of restrictions by the present Amir, 53 .

Afghāns, their migration into Peshāwar in the fifteenth century, $\mathbf{I}_{4} 8$; their rise to power, 16, their dominant position in Northern India during the rule of the Lodis at Delhi, I6; their risings against the Mughals, 16-18, 235, their subjection (1738) of the Mughal governor, 18; Ahmad Shāh Durrāni ruler of the Peshāwar valley, I8, I49; the division of the province between the Bārakzais and Sadozais, I8; frontier settlements with, the Treaty (1879) of Gandamak, 21, the Durand mission (1893-5) and line, 25, 26, et passim under the Political Agencies; the operations on or about the Khyber, in the first Afghān War, 229, 230, in the second War, 230, $23 \mathrm{I}$; the history of the Kurram nnder, 239, $24 \mathrm{I}$; withdrawal (1893) from Wazĩristān, $250,25 \mathrm{I}$.

Afridi waxcloth, a cotton fabric decorated with the oil of the wild safflower, 50 .

Afrīdis, the, a Pathān tribe, inhabiting Tirāh, the mountainous tract sonth of the Khyber, 232, the names, babitats, and strength of their chief subdivisions, 232 ; took possession of the Khyber during Sikh rule, $23^{1}$; took service in the Indian army after Sikh War and served well in the Mutiny, 231 ; garrisoned Ali Masjid (1857-78) for the Afghäns, but were never on good terms with them, 23I; spoiled the Afghāns and harassed the British in the second Afghān War, 231, 232, agreed to keep the Khyber (1879), 232, attacked (1897) the posts and were punished, 232 , agreed to the construction of roads and railways throngh the Pass, 232.

Age, statistics of, 29, returns nntrustworthy, 29, lower mean age of Muhammadans than of Hindus due to their larger number of children, 29.

Agent to the Governor-General, the Chief Commissioner, 57.

Agha Khān, the chief of the Khoja community at Bombay, and head of the Maulai sect, 213 , his adherents in Chitrāl, 213.

Agriculture, 37-47; the difference in soil and character between sub-Himālayan Hazāra and the rest of the Province, $37,3^{8}$; the uncertainty of the rainfall and the large dependence on irrigation and floods, 38,39 ; the two sowings and the two harvests, their seasons and crops, $3^{8-4 I}$; fallows and rotation, $3^{8}$, 39 ; primitive methods of tillage, harvesting, threshing, and winnowing, 39; cultivation of fruits, $4^{\mathrm{I}}, 4^{2}$; statistics of agriculture, 85 ; cattle, horses, and sheep, 43. See also under Agriculture in Districts.

Agriculturists : number dependent on agriculture, 34, 39; 31 per cent. actual 
cultivators, 39, peasant proprietors more than half of these, $39,4^{6}$; agricultural landless labourers few, 40 ; their loans and debts, 42, 43; the rise in wages and in cost of food compared, $46,4^{8}$; the rise in the standard of comfort, 48 ; their extravagance and improvidence, 48 .

Agror, well-watered and fertile frontier valley in the Mānsehra tahsil of Hazāra District, I 39, mentioned in the $R \vec{a} j \bar{a}$ tarangini and by Ptolemy, I39: its history since Tīmūr, 140; turbulence since annexation and punitive expeditions, I 40; land settlement and revenue, 140.

Ahmad Shāh Durrāni, his rule in the Peshāwar valley, 18 .

Akbar the Great, restored the Mughal power in the Province, 17 , the victories of Mān Singh ( $\left.15^{8} 5\right), 17$; the Roshānia ( 1586 ) revolt, 17 ; gave its present name to Peshāwar, 164 ; his agreement with a Khattak chief for the protection of country south of the Kābul river, 170 ; fortified $\left(15^{87}\right)$ the Malakand and Chakdarra, 221 .

Akhund, the, religious and political leader of a colony of Hindustani fanatics, in and about the Swāt country, founded (1829) by Mīr Saiyid Ahmad Shāh, 218,224 ; his famous successor (183577), Abdul Ghafür, 20, 218, 219, 221, his policy of neutrality during and after the Mutiny, 218, compelled to side against the British in the campaign of Ambela, 20, 21, 219, 224, 225; his shrine at Saidu, 221 , his grandsons, $22 \mathrm{I}$.

Akra (or Akarah), ancient site and excavated mound with 'culture strata,' as of Khotan in Chinese Turkestān, near Bannu town, 185, 186, 194, 195 ; finds of Hindu sculpture, engraved gems, 195, bibliography, 195.

Alexander the Great, his campaign in the Province, 13.

Ali Masjid, village and fort in the Khyber Pass, ro $\frac{1}{2}$ miles from Jamrūd, 227 , the difficulty of the road beyond, 228 , its capture by Captain Wade in the first Afghān War, and subsequent sieges, 229, 230, its evacuation by Moseley, 230, garrisoned by the Afghāns (1857$78), 231$; its capture $(1878)$ by Browne in the second Afghān War, 230.

Alienation of land. See Land Alienation Act.

Amān-ul-mulk, the great Mehtar (188092) of Chitrāl, 211, 219, his relations with the Kashmir Darbär and the Government of India, 2II; the political confusion and fratricides after his death, 211, 21 2, a 19. See also Umrā Khān.
Amb, village in independent Tanāwal, whose ruler is Nawäb of Amb, K.C.S.I., $122, I_{3} 8,139$.

Ambela, mountain pass in Buner, just beyond north-east border of Peshäwar Jistrict, 20, 21, 219, 224, gave its name to the Ambela campaign (1863), $20,21,219,224,225$.

Amnsements : fairs and festivals, 36; hawking and snaring in Peshāwar, 146 ; the Peshäwar Vale Hunt, the hounds of, 146 .

Aqueducts : of Swāt River Canal, I 20 ; the famous Jhindi aqueduct, 167 ; of Bärā canal, II 8, II 9 .

Archaeology, general view of, $26-28$; its objects, (a) roads, rock-inscriptions, buildings, and sculptures of Buddhist or Graeco-Buddhist civilization, 27, (b) Muhammadan mosques and religious buildings, 27,28 .

Area, total of Province, of British territory, and of tribes, 1 ; of Districts, tahsils, and of tracts under political control of Agent, given under each. See also Table of Distribution of Population, 84 .

Army, the, 69; its strength, British and Native, 69; its distribution, 69, military stations of cavalry and infantry, 69 ; stations of artillery, 69, of sappers and miners, 69 ; transfer (1886) of Punjab Frontier Force to the control of the Commander-in-Chief, 69 ; concentration (1899) of garrisons at Naushabra and formation of mobile columns at six centres, 69. See also Cantonments, Forts, Outposts and garrisons.

Aroras, a trading caste, $33,130,150$.

Artisans, classes of, 33, 130,150 Sce also under Castes and Occupations in Districts.

Arts and manufactures, 50-52; cotton, wool, silk, 5०, embroidery, jewellery, metal-work, pottery, 5I, woodwork, leather, factories, $5^{2}$. See also under Arts and Manufactures in Districts.

Arya Samāj, their good work in Bannu for female education, 192.

Asgram (in Buner), identified with Asigramma of Ptolemy, 224.

Asoka, his rock edicts near Mãnsehra, 27, 129, 143; established Buddhism in Hazāra and Gandhāra, 13.

Aitock slate, (geological) series in $\mathrm{Ha}$ zāra, 5 .

Aurangzeb, his conciliatory policy towards the Afghāns, $17,18$.

A vitabile, General, ruler $\left(183^{8-42}\right)$ of the Province under Ranjit Singh, 18, I49; enlarged and walled Peshāwar, 16f, 165 .

Awāns, or vassals, next in number to 
the Pathāns, 33; in Hazāra, I3o. See also under. Castes and Occupations in Districts.

\section{B.}

Bābar, his first ( 1505$)$ raid into India, 16 , his subsequent control of the Province, 16; quoted on the irrigation of the Bannu territory, 189; his diplomatic marriage with a Yũsufzai princess, 217.

Baffa, town in Hazāra District, 140 , the principal mart of Northern Hazāra and adjoining independent tracts and a municipality, $140,14 \mathrm{I}$.

Bājanr, tract of five valleys in Dìr, Swāt, and Chitrāl Agency, 222 ; its tribes, commnnal party government,chieftains, and supreme Khān, 222 ; history of, $217,220$.

Bangash, a branch of the Pathāns, inhabitants of the Hangu tahsil of Kohāt District, 169,170 , their characteristics, 172.

Banj (in Buner), possibly the place of the shrine to commemorate Buddha's offering of his body to feed a starving tigress, $27,223,224$.

Bannu District, 182-195, a circular basin drained by the Knrram and Tochi rivers, 182 ; the climate of the District better than that of the town, 183, 194; left desolate by Mahmūd of Ghazni, and gradually colonized by the Bannūchis and Marwats, 184, ravaged by Nadir Shah (1738), the Durrānis, and Ranjï Singh, 184, brought under British influence $(1847)$ by Herbert Edwardes, 185 ; finally (1849) annexed, 185 ; the Akra mound, 185,186 ; its sandy soil, refreshed by silt, manure, and irrigation (30 per cent.), 187-189; metalled tonga roads from Bannu town to Dera Ismail Khān and up the Tochi valley, 189, 190 , the important mule road, connecting the outposts on the frontier, 190; the Marwat tahsil declared insecure from famine, 190 , the diminution of serions crime since the operations ( 1902 ) against the Käbul Khel, 190; the old revenue system of collecting from tappas, 191 ; the first settlement by Edwardes, the last in 1903 , and rates of assessment, 191, 192; education, most advanced among the Sikhs, bnt generally backward, 192, I93; bibliography, 193.

Bannu tahsil, 193, a green, fertile oasis, in the $d o \bar{a} b$ of the Kurram and Tochi, $187,193$.

Bannu town (or Edwardesābād), headquarters of District, a cantonment with a fort (Dhuli fgarh), 193, 194, a muni. cipality and of considerable trade, 194 , 79 miles from Kohāt railway station, 194; a waterlogged, unhealthy site, I94; named after its founder $(1848)$, 194; the rising (1849) of the Sikh garrison, 185 .

Bannūchis, a tribe of Bannn District, 184 ; their evil characteristics, moral and physical, I86, 187 .

Bārā River, a small affluent of the Kābul, rising in Tīrāh, 118, long used for irrigation, I 18 ; its weir for the supply of two modern canals, 118, 119; supplies water to Peshäwar city, I 8 .

Bārā (river) canals, their aqueducts and tunnels, $118,119$.

Bara Gali, small summer cantonment in Hazãra District, I4I.

Barandu, river and valley of Buner, 223.

Barley, next in importance to wheat, its area, irrigation, and yield, 40 . See also under Agriculture in Districts.

Basic dike rocks (dolerites), 5 .

Bāzār, valley in Khyber Political Agency, 236, inhabited by the thieving Zakka Khel or clan of the Afridis, $23^{6}$, pnnitive expeditions (18/9-98) against, 236 .

Beecher, Major, his firm hold of Hazāra District during the Mutiny, 129.

Bhang, generally imported from the Punjab, 66, its considerable consumption, 66 , restrictions on sale, 66 , duty on, 66 , revenue from, 67 .

Bhittanni, tribe inhabiting the hilly, bare country between Derajāt and Mahsūd territory, 255,256 , partly under political control of Deputy-Commissioner of Dera Ismail Khān, 255, expedition (1880) against, 80; lately identified with British interests and forming a company of South Wazīristān militia, 255 ; their hereditary feud with the Mahsūds, 255; their more civilized ways, 256 .

Bibliography: of the Province, 77,78 ; of Himālayas, 107; of the Indus, 116 ; of Districts, Hazāra, 137, Peshāwar, 157, Kohāt, 178, Bannu, 193, Dera Ismail Khān, 205; of Akra, I95, Kafīkot, 208, Takht-i-Sulaimān, 257.

Birth-rate, statistics of, 30 , the marked excess ( 120 to 100) of inale over female births, 30 .

Bisliops, Anglican and Roman Catholic, of Lahore, 34 .

Black Mountain, range on the northwestern border of Hazāra, 107,25 to 30 miles long, 8,000 feet high, 107 , its passes and gorges, 107 ; its turbulent tribes, 107; numerous punitive expeditions against from 1851 to $1892,20-22$, $80-82,107,108$, their complete pacification, 108 . 
Boat-building, 52 .

Bokhāra, steady decline of trade with, due to transit and customs dues imposed by Russia and Afghānistān, 53, trade through Peshāwar, 153, 166.

Botany, general view of, 8-10, of the plains as of the south -east of Punjab, mainly shrub jungle, 8 , of Wazĩistān and of the Karram valley, 8, 9, of the Safed Koh, 9, of the hills north of the Käbul river, 9, of higher and more northerly tracts, as of Kashmir, 10; of Himālayas, 102, 103. See also under Botany in Districts.

Boundaries, of Province, $\mathrm{I}$; of Districts and Regions, see under first paragraph in each.

Boya, village in the Daur valley with garrison of Northern Waziristān militia, 245.

Bridges : (railway) over Indus (and subway) at Attock, 54, 111,154 , in constrnction at Khushălgarh, 54 , in Sind, 112 ; (boat) over Käbul river at Naushahra, 164, over Indus at Attock, Khnshālgarh, Dera Ismail Khān, 54, $55,5^{6}$, over Kābul river, 118 , 154 , 164 ; (road) over Swāt river, I 54, 161, over Landai, I 54; (swing) over gorges of the Himālayas, I06; (iron suspension) over the Kunhār, Kishangangā, and Jhelum rivers, on the main Kashmir road, 134 .

Buddha, his offering of his eyes, 161 , of his body, 27, 223, 224. See also Buddhism.

Buddhism, remains of, 27; Gandhāra a great centre of, and of Graeco-Buddhist art, 124,147 , the reports of $\mathrm{Fa}$ Hian (c. 404), Hinen Tsiang, and of U-K'ong, 124, 147; persecuted (A.D. 515) by Mihirakula, the Hun, I24; remains of, in Hazära, 27, 129, I 43 ; the stüpa and shrine where Buddha made an alms-offering of his eyes, at Chärsadda, I 61 , of his body to a starving tigress, at Banj, 224 , the begging-pot of Buddha, a holy fipal tree, and Kanishka's enormous sliupa, once at Peshāwar, 164; the Gor Khattri,once a monastery, 165 ; Buddhism (c. A.D. 900) of Chitrāl and Mastūj, Dīr and Swāt, 210, 211, 21 7; identification of its sites in Buner by Dr. Stein, 223, 224; remains of, west of Khyber Pass, 227. See also Asoka.

Buner, tract on north-east border of Peshāwar District, under political control of Deputy-Commissioner, 223 , comprises the isolated, fertile basin of the Barandn river, 223 ; its interesting archaeological remains investigated (1898) by Dr. Stein, 223, 224; its history, 21 7-220.

\section{C.}

Camels, largely used but not bred save in Kohăt District, 43 ; trade caravans of, $53,202,208,253$.

Canals, for irrigation, 43-45, $120-122$, their present and proposed areas of supply, 43-44, of the Indus, 114,115 , their administration, $58,68,69$, revenue and expenditure, 45,88 ; canals south of Peshāwar, private, 45, 189, 201. See also under Irrigation in Districts.

Canara, Colonel, in Sikh employ, killed by insurgents at ontbreak of second Sikh War, monument to at Maripur, I 41 .

Cantonments: Abbottābād, 139, Bara Gali, 141, Ghora Dakka, 141, Kalābāgh, 142, Khaira Gali and Khanspur, 142, Dera Ismail Khān, 207, Hangu, I80; Jamrūd, 233 ; Kohāt, I8o; Mardān, 163, Naushahra, 69, 163 ; Peshāwar, 164, 165, 166 ; Cherāt, 161, 162. Castes, classes, and tribes, 32,33 ; Pathāns, 32, 33 ; Awāns, Gūjars, Jats, \&ec., 33: Hindu castes, 33 ; artisan and menial classes, 33. See also under Castes in Districts.

Cattle, poor except the Peshāwar buffalo, 43. See also under Cattle in Districts.

Cess, consolidated for District boards, 68 .

Chakdarra, military post on the Swāt river, 221, garrisoned (1895) by the Chitrāl relief force and since retained, 221 ; its siege (1897) by the 'Mad Mullā,' 221.

Chamberlain, General Sir Neville, commander (1863) in Ambela campaign, $20,21,81,225$, and in 1855,1859 , and 1860 in frontier expeditions, 80,81 , 239,250 ; his friendly mission (1878) to $\Lambda$ mīr of Afghānistān repelled at $A \overline{l i}^{-}$ Masjid, 230.

Chāngla Gali, small hill station in Hazāra District, 141 , head-quarters of Northern Command School of Musketry, 141 .

Charas, hemp drug, imported in bond from Central Asia, 66, also smuggled from Bokhāra through Chitrāl, 66, restrictions on sale, 66 , duty on, 66 , revenue from, 67 .

Chārsadda, tahsill of Peshāwar District, consists of a well-irrigated and fertile doāb, between the Swãt and Kābul rivers, and of the Hashtnagar tappas or circles, 158.

Chārsadda tọnn, on Swāt river, head-quarters of talisill in Peshāwar District, large and prosperous, 161, connected with Peshāwar by a good road of 20 miles, with five permanent bridges of boats, 161; with Prāng identified as Puslıkalāvati, capital of region in Greek times, 161, its extensive ruins and finds of coins and 
pottery, I6I ; once a place of pilgrimage and of the stiupa commemorating Buddha's alms-offering of his eyes, 161 .

Chaukidärs, village watchmen or raral police, their appointment, duties, remuneration, and number, 7o, 7r, 9I.

Cherāt, hill sanitarium $(4,500$ feet) and (summer) cantonment (1886) in Peshāwar District, 16r, good water-supply and bearable June nights, $x 6_{2}$.

Chief Commissioner, the, also Agent to the Governor-General, 57.

Chinese pilgrims to Gandhāra, their reports on the state of Buddhism, 124, saw well-wooded slopes now bare, 153 .

Chitrāl, State in the Dïr, Swāt, and Chitrāl Agency, 210-2I5; comprises three fertile, well-cultivated valleys, 2 ro, 2I4; the Mehtar or chief descended from Sangin Alī (d. I570), 2 I I ; the great Mehtar, Amān-ul-mulk (I 88092 ), his friendly relations with the British, 2 I I, his death followed by wars, fratricides, and revolutions, 2 I1, 2 I 2 ; the invasion and successes against the British of Umrā Khān, 21 2, the siege of the Political Agent at Chitrāl (1895), 2 I2, raised by a force from Gilgit and finally relieved by a force from the sonth, 213 , the dispersion of invaders and insurgents, $2 I_{3}$; its present reduced garrison, 2 I $_{3}$; the visits of the Mehtar to Calcutta (1900), the Delhi Darbār (1903), and to Peshāwar (1904), 213 ; the languages and uncertain origin of the three strata of the people, the lowest only paying taxes and land revenue, $2 I_{3}$, their religion and justice, Muhammadan, 2I3, 214 ; their mineral industries, 214; administration and exaction of revenue, 2 I 4 ; medical, 2 I 3 ; the sale of girls to Afghän harems, 214.

Chitrāl (Chitrār or Kashkār) town, or group of villages, 2 I 4, capital of Chitrāl State and seat of the Assistant Political Resident, 2 I 5 ; the siege (I895) of the fort, 2 I 2.

Chitrāli Scouts, a feudal militia of marksmen, under honorary command of the Mehtar, for the defence of the passes into Chitrāl, 72, their strength, period of service, and armament, 73, 2 I 3 .

Cholera, an occasional visitant, deaths per 1,000 from, 30 .

Christian missions, flourishing of the Church Missionary Society, 34, their good work in female education, I57, $19^{2}$, the benefits of the medical mission, 34,76 . See also under Christian Missions in Districts.

Civil courts of justice, 6o; statistics of, 87.

Civil and military surgeons, 76 .
Clerks, income and expenditure of, 47 .

Climate and temperature, very diversified, of hills and plains, I I, 12. See also under same head in Districts.

Coal, its occurrence in Hazāra, 7, I 27.

College, Edwardes Church Mission (the only one in the Province), affiliated to the Punjab University, 74 .

Communication, means of, railways, roads, rivers, post, $54-56$; of Hazāra District (no railway), I34, Peshāwar, 15.4, Kohāt, I75, Bannu (no railway), I89, 190, Dera Ismail Khān (no railway), 202, Kurram Agency, 24I. See also Railways, Roads, Rivers, Bridges, Ferries, Fords, Passes, Mail tongas.

Conveyance and Carriage, means of: mail tongas, 55, other means, mainly pack-camels, 55 .

Copper-ware, hammered, and for Muhammadan use tinned, a speciality of Peshāwar, 5I ; the Persian character and feeling of the forms and chasing, $5 \mathrm{I}$.

Cotton, grown mostly in Peshāwar and Dera Ismail Khān Districts, 4I, its area varying between 3 and Iog square miles according to season, 41 , 151 ; importation of, 85 .

Cotton, industries, 50 ; imports of piecegoods, 8 .

Courts of justice, civil and criminal, 60, 61 ; council of elders, 61 .

Cretaceous rocks, with characteristic cenomanian fossils, 6,7 .

Crime, statistics of cognizable, 71 .

Crimes. See under Civil Justice and Crime in Districts.

Criminal courts of justice, $60,6 \mathrm{r}$; statistics of, 87 .

Crops, determined more by irrigation, floods, and rainfall than by fertility of soil, 38,39 ; rotation of, 39 ; the principal, with their season, area, and yield, $40,41,85$; double crops, 38 , 39, their area, 85. See also under Agriculture in Districts.

Crystalline, igneous, and metamorphic rocks, 4 .

Cultivation, conditions and state of, in the settled Districts, 37-39; cultivated, cultivable, uncultivable, and non-cultivated areas of the Province, 85 ; the total and cultivated areas of each tahsil, under Chief Agricultural Statistics in Districts. Sec also Agriculture, Crops. Customary law, its wicle sphere of application, 59, in the Kurram, 24I, of the Dauris, $\mathbf{2 4 7}$, of the IVazirs, 252.

D.

Däman, 'skirt of the hills,' a great plain stretching between the Indus and the 
Snlaimān mountains, 38,195 ; a natural desert transformed by irrigation, 195, 196, 200.

Dargai, military station in the Peshäwar division, 69,219 , at the foot of the Malakand Pass, 220 ; railway to, from Naushabra, 5 .

Danr, valley of the Tochi river and only administered portion of the Northern Waziristān Agency, 246, unhealthy in the hot season, 246 ; taken over ( 1895 ) at the pctition of the inhabitants, 246 , the Danris, a despised Afghān race of 'satyr-like spadesmen,' 246 ; the great fertility of the valley, 247 , its cottonweaving industry, system of rents, irrigation, and customary law, 247; the land settlement, with payment in cash or kind, $247,24 \mathrm{~S}$.

Dead, disposal of, as elsewhere, Hindu by cremation, Muhammadan by bnrial, $3^{6}$.

Death-rate, statistics of, 30 ; infant mortality, 30; deaths from principal diseases, 30 ; in jails, 73,74 .

Density of population, 28 ; statistical table of, 84. See also under People in Districts.

Deodār, forest revenue mostly from sale of, 47 .

Dera Ismail Khān District, 195-209; between the Indus and the western hills, 195, the daman or 'skirt of the hills,' cleft and fertilized by the silt of rain-fed torrents, $195,196,200$; geology, $19^{6}$; fairly healthy, 197; its history under Baluchi Hots, Durrānis, and Sikbs, 197, I98; under Edwardes (1847) and the British, 198; irrigation (4 per cent.) mostly by private canals, 201 ; its trade, mainly through, 202 ; its nearest railway station at Daryā Khān over the river, 202 ; summary and regular settlements, 203 ; the high standard of literacy among Sikhs and Hindus, low among Muhammadans, 204 ; bibliography, 205.

Dera Ismail Khān tahsil, a bare, generally barren plain, with extreme scarcity of water in the hot season, 205.

Dera Ismail Khān town, head-quarters of the District and tahsill, and an extensive cantonment, 207; original town swept away $(1823)$ by the Indus, 207 ; its two bazars and separate quarters of Hindus and Muhammadans, 207 ; winter headquarters of Derajāt lBrigade, 207; a municipality with bad drainage, 207 ; increasing trade with Khorāsãn and Afghānistān by Gomal Pass, 208.

Derajāt, local name of the plain between the Indus and Sulaimān range, I 22, includes the three Deras, 122 ; the Baloch immigration in the fifteenth century, 122 ; the dynasty of the Mirānis for fifteen generations at Dera Ghāzi Khān, 122 , 123 ; overlords of the Baloch feuda. tories of Käbul, 123; nnder the Durrānis, 123; tributary to the Sikhs, 123 ; annexed (1849) by the British, 124 ; the Derajāt Brigade, 69, 207.

Dir, 215,216 ; territory in the Dir, Swāt, and Chitrāl Agency, 215, comprises the country drained by the Panjkora down to its junction with the Bājaur, 2 I 5 ; fairly fertile and well cultivated, 216 , unhealthy in its lower regions, 216 ; its Khān, the overlord of the clan chiefs, 216 ; its tribes and languages, 216 ; the Dir levies, 216 ; its history, 21 7-220.

Dīr, Swāt, and Chitrāl Political Agency, 210; formed I 896, Chitrāl added (1 897) from the Gilgit Agency, 210 ; bounded, ronghly, north, east, and west by the Hindu Kush, Kashmīr, and Af ghānistān, 210; head-quarters on the Malakand Pass, 221.

Dir, Swāt, Bājaar, and Utmān Khel, their history, 21 7-220; their early Buddhism and Hindu population and kings, 217 ; the invasions in the fifteenth century of the Yūsufzais, and introdnction of Mnhammadanism, 2I 7 ; their restlessness under the Mighals, 217,218 ; their religions dissensions, 17,218 ; their independence from the decline of the Mughals to the time of Nādir Shāh, 218 ; the strong rule of the Akhund, a religious leader $(1835-77), 20,218$, 219 ; the British punitive expedition or campaign (1863) of Ambela, 20, 21, $219,224,225$; the intrigues and aggressions of Umrā Kbān of Jandol, 212 , 219 , the rising (1897) under the " $\mathrm{Mad}$ Mullā,' 22, 23, 220; the opening (1901) of a railway from Naushahra to Dargai at the foot of the Malakand, 54, 220 ; subsequent internal disturbances, 220.

Diseases, principal, and the mortality from, 30 ; in jails, 73,74 .

District, the, unit for police, medical, and educational measures, 58 , the DeputyCommissioner of, and his ordinary staff, 58.

District Boards, their finance and sphere of dnty, 68,90 , consultative, not initiating, bodies, 68. See also under Local and Municipal Boards in Districts.

Divorce, 31 .

Do-Kora ('two homes'), term applied to Mohmand settlers for a season, 225 .

Donkeys, stallions maintained by veterinary department, 132, 152.

Dress and coiffure of men and women, 35 ; Hindus formerly not allowed to wear turbans, 35 ; the cost of, to wageearning classes, 46,47 . 
Dungā Gali, small sanitarium in Hazāra District, $14 \mathrm{I}$.

Durand, Sir Henry, fourth LieutenantGovernor of the Punjab, killed (1870) by an accident at Tânk, 198, buried at Dera Ismail Khān, 198.

Durand, Sir Mortimer, negotiated the Dnrand line (1893-5) with Afghānistān, $25,26$.

Durrānis, rule of, in Peshāwar, 18, in Derajāt, I 23. See also Afghāns.

Dwellings, geuerally a single room, with walls and roof often of mud, 35 ; its furniture, 35 ; the village guest- and club-house, 36 .

\section{E.}

Education, its present organization under an Inspector-General, 74 ; the Edwardes Church Mission College at Peshāwar, 74; primary and secondary (male) schools, 74, 75; female education of Muhammadan girls by themselves in Urdū schools, 75, of Hindu and Sikhs in Hindī or Gurmukhī, 75; Muhammadan education, backward but progressing, 75, 192, 204 ; statistics of schools, public and private, pupils and finance, 75,92 . See also under Education in Districts.

Edwardes, Sir Iferbert, his pacification $(1847-8)$ and settlement of the Bannu valley, and of Dera Ismail Khān, I85, 19I, 203; took part (1848) with new and loyal levies at the siege and storm of Multān, $185, \mathrm{~J} 98$; founded ( $184^{8}$ ) Edwardesābād, 194; the Kābnl gate at Peshāwar in his memory, 165; his policy in Tānk, 206.

Edwardes Church Mission College and Anglo-vernacular school at Peshāwar, $74,166$.

Edwardesābād. See Bannu town.

Embroidery, herring-bone, with silk and on muslin, $5 \mathrm{I}$.

Excise, revenue from spirituous liquors and intoxicant drugs, $65-67$; number and location of shops for retail of, fixed, 66 ; auction of licences, 66 ; consumption per head, 65 ; the control of, in the Agencies, 66.

Exports, across the border, 54; table of values, 87 , the excess of value of exports over imports, and the excess of exported over imported treasure, 54 ; to other Provinces and States of India, 54; of Peshāwar, 153, 166, of Dera Ismail Khān, 202, 207, 208.

Eye, affections of, common in hot, dry Districts of Bannu and Dera Ismail Khān, 3o.
F.

Factories, one cotton-ginning and cleaning at Peshāwar, 52, ice factories at Bannu and Kohāt, 52.

Fairs and festivals, 34,36 .

Fakir, term applied to a Pathān who has lost his share in the estate and his voice in the councils of the tribe, $\mathbf{3}^{2}$.

Fakir miskin ('poor beggars'), the lowest and only tax-paying class in Chitrāl State, $213,214$.

Fallows, $3^{8}$.

Famine proper never recorded, 56, the absence of its conditions, want of water and pressure of population, $5^{6}$; the several Districts in respect of presence of rainfall or irrigation or both, 56,57 ; resources of the population other than agriculture, 56, 57; Marwat tahsil of Bannu District declared (1903) insecure from, 190.

Fault (geological), the great, 5 .

Fauna, general view of, 10, ir, of large carnivorous game the tiger now extinct, 10, deer, märkhor, and uriāl, 10; game-birds, birds of prey, and others, Io, fish and snakes, 10, II ; of Himàlayas, 103, 104. See also under Fauna in Districts.

Female education, 75 ; statistics of, 92.

Ferries : over Indus, steam at Dera Ismail Khān in hot season, its difficnlties, 56 , ordinary boats, 56, I II, I16, I54, 202 ; inflated skins, giving facilities to criminals and so requiring licence, 56 ; often swept away, IIo; over Kăbul river, 118, 154, 163, over Swāt, 154, 160 , over Landai, 154.

Festivals and fairs, 34,36 .

Finance, 61-67; revenue and expenditnre wholly Imperial, 6I ; statistics of, since $1902-3,88$; large excess of expenditure over income due to requirements of Imperial policy, 62 ; land revenue, $62-64$; miscellaneous revenue, $6_{4}-6_{7}$.

Fishing, in the Indus, 116,128 , in Hazara, 128, in Peshāwar, 146 , in Kohāt, 169.

Floods, of the Indus, $11_{4}$, of the Kanbul river, is 8 , of the Gomal, 120.

Food, of peasants improved since annexation, 34 ; generally vegetarian, from economy not principle, 35; outside of towns the use of spirits and opium disreputable, 35 ; vain efforts of Mullās to stop nniversal smoking, 35 ; its price compared with wages, $46,4^{8}$.

Food-grains, their total production, 4I, their greater consumption due to immigrants and Government servants, $4 \mathrm{I}$; imports of, 53,86 ; average prices of (1880-1903) in Peshāwar and Dera Ismail Khān, 48 . 
Fords, of the Indus, 110, I13; of the Sivàt, I1 6 ; of the Käbul river, 118 , the catastrophe $(18 \% 9)$ at the Jalālābād ford, 118.

Forests, 'reserved' and systematically administered only in Hazāra, 48, 132, I33; financial results of, mainly from sale of deodär, 48 ; other forests, their general administration and principal trees, 48, 49, 133 ; once cornmon in Peshāwar, 152, 153. See also under Forests and Chief Agricultural Statistics in Districts.

Forts, of the Sāmāna range, 109; the Bāla Hisār, outside Peshāwar, 16.5, Dhulipgarh of Bannu, I94, of Chitrāl, 212, 213, of Mastūj, 215, Abāzai, 16r, 162, Alī Masjid, 228-230, Jamrūd, 233, Landi Kotal and other posts in the Khyber, 233, Kurram, 240, Fort Lockhart, I81, Fort Mackeson, 162, Michni, 163, Mardān, 163, Shabkadar, 167; mud fort of Tānk, 209 .

Fox-hounds, pack of, at Peshāwar, 146.

Frontier, settlement of, and control over, by Treaty of Gandamak, 21, 231, 232 ; the Durand line $(1893-5), 25,26$; border military police, $7 \mathrm{I}$, militia, 72 .

Frontier tribes, expeditions against,20-26 ; a table of, 80- 82 .

Fruits, cultivation, home consumption, and exportation of, $41,4^{2}$; in the suburbs of Peshāwar, $16_{5}$, of Kurram valley, $24 \mathrm{~J}$. See also Orchards.

\section{G.}

Gambila. See Tochi river.

Game, large and small, quadruped, winged, and finned, 10, I1. See also under Fauna in Districts, Fishing, and Amusernents.

Gandamak, Treaty of (1879), giving the British the control of the Khyber and Mohmand Passes, 21, $231,232$.

Gandhāra (Gandaria of the Greeks), the ancient name of a tract including Peshāwar District, the Mohmand country, Swāt, Bājaur, Bnner, part of Kohāt, and the great city of Takshasila, 124 , I 47 ; sent a contingent to Darius in his invasion of Greece, 124 ; its capitals at different times, 124,125 ; a great seat of Bnddhist and Graeco-Bactrian culture till about A.D. 515, 124; the famous Gandhāra school of sculpture, 124.

Gardens. Sce Fruits and Orchards.

Geology, gencral view of, $4-8$; its great diversity, 4 , the older unfossiliferous formations, 4-5, the later Mesozoic and Tertiary rocks to the south, 5-7; the salt rocks below the Nummulitic beds, 7,168 , post-Tertiary and recent formations, 7,8 , evidence of old glacial moraines, 8; of the Himālayas, 98-102. See also under Geology in Districts.

Ghora Dakka, small (summer) cantonment in Hazāra District, 141 .

Gomal or Gumal river, 119 , rising in Afghānistān, enters British territory at Domandi, I 19, its tributaries, I I 9, 120 ; irrigates Dera Ismail Khān, I20; its waters do not reach the Indus save in flood times, 120; in Southern Waziristān, 249.

Gomal (or Gumal) Pass, from Dera Ismail Khān through the Southern Waziristān Agency to the Afghān plateau, 253, 254; the oldest and most used of the trade rontes between India and Afghānistän, $53,208,253$, the armed caravans of the Powindas, 53, 202; measures taken by the British for its protection by the Mahsūds and themselves, 250, 251,254 .

Gorkhatri, the, at Peshāwar, once a Buddhist monastery, since a Hindu temple and rcsidence of Avitabile, and now a tahsili, 27, 28, 165 .

Graeco-Bactrian Kingdon, 13, 14; Gandhāra a great sent of its culture, 124 ; find of coins in Takhli, 129, in Peshāwar valley, I47; traces of, at Akra in Bannn District, $185,186,195$.

Graeco-Buddhist art and civilization, remains of, 27 ; at Gandhāra, 124, 127 , 147.

Gram, a spring harvest crop, its area and yield, 40.

Greeks, the, Alexander's invasion ( 327 B. C.), and his successors, 13,14 ; Peshāwar, the meeting-place of Greek with Buddhist culture, 146, 147.

Guest-house, in every Pathān village, 36 . Guides, Queen's Own Corps of, stationed at Mardān, I6 3 .

Guinea-worm, a disease due to drinking tank-water, 30.

Güjars, the, a tribe professing to be aborigines, the places of their strength, 3.3; predominant in Hazāra District, 130.

Gumal. Sce Gomal.

\section{H.}

Hangu, tahsīl (or Mīrānzai) of Kohāt District, consisting of the fertile Mirānzai valley, 179, inhabited by a tribe of the Bangash Yathāns, 179.

Hangu village, head-quarters of tahsil, and of Thal subdivision, 180 , a station on the Khushälgarh-Thal branch of the railway, 180 , its summer and winter garrison, 180 .

'Hangu breeze,' the, a cutting west wind blowing down to Kohāt, 169. 
Harīpur, tahsïl of Hazāra District, 137. Ilaripur town, head-quarters of tahsil (and of District, 1849-53), and a municipality, 141 ; the obelisk over the grave (1848) of Colonel Canara, 14 r.

Harrests : kharif or antumn, sown from May to August, 38, rabi or spring, sown from October to Jannary, 38 ; the chief crops of each, 40, 41. See also under Agriculture of Districts.

Hashtnagar ('eight cities'), a tract of high plain and lowlands, from the east of the Swāt to the Kābul river, 162; disputed derivation of the name, $\mathbf{1} 6 \mathbf{6 2}$.

Hazāra, origin of the name, probably Urasā, the ancient name of Pakhli, 124, I 28, I 29.

Hazāra District, I 26-143; the only territory of the Province east of the Indus, 1 26, a wedge thrust between Kashmir and the independent hills of the west, 125 ; its variety of scenery, altitude, and climate, 126, 128; geology, 127; plentifnl fanna, 127,128 , healthy climate and abundant rainfall, 128 ; its obscure history before the Durrānis, 1 28, its slow subjection by the Sikhs, 129, transferred by exchange to British after frst Sikh War, 129, its firm rule by Major Abbott (1847) before and during the second Sikh War, 129, of Major Beecher during the Mutiny, I29, final pacification of the Black Mountain, 129; its important archaeology, 129 ; population, with a table of statistics, 1 29, 130; agriculture, I 31, 132, its important 'reserved' and village forests, I32, I33; no railways, the principal metalled road from Attock to Kashmir, 134; administration, 135 ; land settlement and revenue, the reduction of the Sikh demand, 135, 136; backward edncation, 136,137 ; bibliography, 137 .

Headmen, village, collectors of revenne, $5^{8}$; as responsible officers, a British innovation, 67 .

Hill stations, Chāngla Gali, 14 I, Nathia Gali, I 43, Sheikh Budīn, 209. See also Cantonments, Forts, Sanitaria.

Hills. See Mountains.

Himallayas, the ('abode of snow'), 94107; our imperfect knowledge of them, fassim; their extent from the Dhäng river on the east to the snows on the west, 94, 97; their political distribution, 94,95 ; a series of high ranges with diverging spurs (Outer Himallayas) ending abruptly, 45 ; the final and lower range of Siwāliks, 95, 99 ; the true watershed the bonndary between India and Tibet, 95; scenery, snowline, and protruding glaciers, 96, 97 ; highest peaks, 97 ; the source of the great rivers of the Indo-Gangetic system, 97; the valleys of Kashmir and Nepāl, $97,9^{8}$; geology, $98-102$; origin due to a great folding, mainly in Tertiary era, 98, 99; flora, 102, 103 ; fauna, 103,104 ; tribes, religions, and languages of people, 104, 105; crops and forests, 105, 106; present and projected means of communication by railways, roads, bridle-paths, passes, swinging bridges over great rivers flowing in deep gorges, 106; bibliography, 107.

Hindu Kush or Koh, or Indian Cancasus, 3 , separated by the Indus from the Himālayas proper, 94 .

Hindus, number of speakers of Hindī and kindred dialects, 32 , marriage among, 30 , cremation of dead, 36 , as traders, 33 , formerly not allowed to wear turbans, 35 , honorific titles of, 37 , male and female education among, 75,204 , by Pathãn customary law among the Dauris a Hindu counts as half a man, 247.

History of the Province, i 2-26; its always closer political relations with Eastern Irān and Afghānistān than with India, 12 ; as two satrapies of the Persian empire, 13; during the Greek invasion and short occnpation, 13 ; under the Mauryans and Asoka, I3; the Graeco-Bactrian power, I3, I4; under the Kushans, $1_{4}$, under the White Huns, I4; part (c.A.D. 1000) of the Ghaznivid empire, $1_{5}$, under the Ghorids, 15, Mongol invasions and supremacy, 15, 16; 'T̄̄mūr's (1398) devastation, 16; the rise of the Afghāns to power, 16; under Bābar, Akbar, and the Mughal power (1526-1 738), 16-18; the revolts (1586-1660) of the Roshānias, I7; Nãdir Shāh and Abmād Shāh Durrāni, 18; under the Barākzais and Sadozais, 18; the invasions and conquests $(1818-49)$ of the Sikhs, 18; British annexation (1849) and administration, 19; the frontier Districts a source of strength during the Mutiny, 19. 20 ; the frontier tribes and Afghānistān, British relations with as determined by the Treaty ( 1879 ) of Gandamak, 21 , and the Durand line (I 893-5), 25,26 ; expeditions against the frontier tribes (1 849-1902), 20-26, a statistical table of, 80-82; formation (1901) of the Province, 26.

Hiuen Tsiang, Buddhist pilgrim from China of the seventl century, laments decline of Buddhism in Gandhāra, 124, 161, found Pakhli tributary to Kashmir, 125, describes Und, 125; his $\mathrm{Ki}$ Kiangha and Falana identified with Kurram and Bannn, 26, 27. 
Honorific titles, 37 .

Horses, donkeys, and mules, their breed encouraged by Imperial Remount department in Hazāra and by District Boards, 43. See also under Cattle, Ponies, and Sheep in Districts.

Hospitals and Dispensaries, 76 , statistics of, 93. See also under Hospitals and Dispensaries in Districts.

Hot (Baluchi) dynasty of Upper Derajāt from fifteenth to eighteenth century, 197, founded by Malik Sohrāb, 197, 207 , the towns fonnded and named by his sons Ismail and Fateh Khān, I97, 207.

Huns, the White, held Northern India, 14, their king Mihirakula. defeated $(\mathbf{5 2 8})$ by a confederacy of Indian princes, $1_{5}$; his persecution of Buddbism, I 24 .

\section{I.}

Idak, village and garrisoned post in Northern Wazīistann Agency, in the Daur valley, 245 .

Imports, from across the borders, 53, a table of values, 87 ; from other Provinces and States of India, $5+$, a table of items and values, 86 ; of Peshāwar, 153, 166, of Dera Ismail Khān, 202, $207,208$.

Income tax, revenue from, number of assessees and incidence, 67 .

Indus river (Greek, Sinthos; Latin, Sindus), the great river of North-Western India , 4, I09-114; its course of 1,800 miles, and the principal towns on its banks, 109; its gorge through the Himălayas, I10; in the North-West Frontier Province, 110; its great tributaries, IIO, III; its width, depth, fall, velocity, volume, temperature, and colour at different places and seasons, 109-I 12 ; navigable below Attock, 110 ; its bridges and ferries, 110-112; its timberless and generally infertile delta, I I $2,1_{13}$; its changed course and shifting channels and estuaries, I13, II its inundations, embankments, and irrigation, II $3 \mathrm{II}_{4}$; its principal canals, 114,115 ; its difficnlt navigation and disappointing traffic, II5, I16; fish, and boats, I16; bibliography, I 6 .

Infant mortality, not high, if registration were full and trustworthy, 30 ; female infanticide not suspected, 30 .

Infra-Trias (geological), formation of Hazāra, 5, 6.

Inoculation, old hereditary habit of, 77 .

Intoxicants (liquors and drugs), the rcstrictions on their frce use by limited manufacture, by duties, by limiting the number of licensed shops for their sale, by selling licences, $6_{5}, 66$, the amount, slightly decreasing, of their consumption per head, 65 ; general abstinence of Muhammadans from alcobolic liquors, not from drugs, $6_{5}$.

Intoxicating drugs. See Bhang, Charas, and Opium.

Intoxicating liquors: imported beer, sale of, 66 ; country spirits, manufacture of, in the Province, 66, importation of, 66 , consumption of, 66 ; restrictions on sale, 66 ; revenue from, 67 .

Iron-work, manufacture of sword-blades and knives at Peshāwar and of firearms in Kohāt Pass, 51 ; once a common industry of the frontier, 51 .

Irrigation, $43-45,57$; of cultivated area 25 per cent. by canals, 2 per cent. by perennial streams or floods, I per cent. by wells, 43,85 ; present and projected canals and their sources, $43-45$, I 20I 22 ; areas of, 44,57 ; system of water distribution, 45 ; canal revenue and expenditure, 45,88 , the insanitary effects of excessive, at Bannu, 183 ; transformation of the diman desert by, 195 , I96, 200.

\section{J.}

Jails, 73, 74; nnder Administrative Medical Officer of Province, 73 ; statistics of their number, population, earnings, decreasing mortality, and increasing cost, 73 ; the causes of the decrease in mortality are also causes of increased cost, 74. See also zunder Police and Jails in Districts.

Jamrūd, fort and cantonment at mouth of Khyber Pass, just beyond the border of Peshāwar District, 233, head-quarters of Khyber Rifles, and the toll station for the Pass, 233; large mobilization camping-ground between it and Peshāwar, 233, its branch railway line, 233 .

Jandola (or Jandula), village of the Bhittanni, and fortified post on the border of the Sonthern Waziristān Agency, 256.

Jats, practically all Muhammadans, numerous in the Indus Valley, 33, 199.

Jewcllery, mannfacture of, at Peshāwar and in Hazāra, 5 r.

Jirgas, or councils of elders, $6 \mathbf{r}$.

Judicial Commissioner, the, supreme civil and criminal court of, 60 .

Jurassic (geological) formation, 6 .

Justice, in the Province, based on customary law, and in its absence Hindu or Muhammadan law, 59, its civil and criminal courts, judges, and magistrates, 60,61 ; in the trans-border territories, 61 ; in Chitrāl, 214; in the Kurram Agency, 24! . 
K.

Kābul river, its sonrce in Afghānistān, II , its tributaries and rapid growth below Kābul city, I17, reaches British territory near Michni fort, 117 , after a course of $3_{16} 6$ miles joins the Indus at Attock, II ; useful only for irrigation to Jalāāābàd, $11 \%$, thence to Dobandi, navigable by skin-rafts, 117,118 , thence by boats and small ships, 118 ; its fords, ferries, and bridges, i1 8.

Kābnl River Canal, a perennial irrigation work, supplying 30,000 acres, 121, a revival of an old Mughal work, 121; its channels and district of supply, 121 ; capital cost and profit of 24 per cent., 122.

Kāfirkot (Til Kāfirkot, Rājā Sir-kot), extensive ruins of walls and temples in Ismail Dera Khān District, 208, sonth of the junction of the Kurram with the Indus, 208.

Kāgān (or Khāgān), mountain valley in Hazàra District, I 42, the most northerly point of British India, $\mathbf{I 4}^{2}$, surrounded save at its month by the high hills of Kashmir, 142 ; its large 'reserved' forests, and timber rafts down the Kunhār to Jhelum, 142.

Kālābāgh, small (summer) cantonment in Hazära District, $\mathbf{1}^{2} \mathbf{2}$

Khāgān. See Kāgān.

Khaibar. See Khyber.

Khaira Gali, small (snmmer) cantonment in Hazära District, I 42.

Khanspur, part of Ghora Dakka (summer) cantonment in Hazära District, $\mathbf{1} 42$.

Khattaks, a Pathān tribe, dominant in the Deri tahsil of Kohāt District, 169, 170 ; their moral and physical characteristics, $172,179$.

Khattris, a trading caste, $33,130,150$.

Khels or clans of Pathān tribes, for principal see Afrīdis, Orakzais, Wazīrs, Yūsnfzais; also Expeditions against Frontier Tribes, 20-25, 80-82.

Khushālgarh, railway bridge over Indus at, 54,175 .

Khyber (or Khaibar), celebrated Pass from Peshāwar District into Afghānistān, now part of the Khyber Political Agency, 227-232, over the last spurs of the Safed Koh, 227; 33 miles long from Jamrūd to Dakka, 3,400 feet high, 227 ; its chief points and conditions of ascent and descent, 227,228 ; always a gateway into India, 228, its history, 228, 229; first crossed by a British force (1839) convoying Shāh Shujā's son to Kābul, 229, in the first Afghān War (1839-42), 229, 230; in the second Afghān War (1878-80), 230, 231 ; the
Khyber tribes left under British control by the Treaty (1879) of Gandamak, 231, 232, the care of the Pass entrusted to the tribesmen, 232, their treachery (1897) and punishment, 232, the last (1898) settlement with the Afridis and angmentation of Khyber Rifles, 232; Landi Kotal and other posts in the Pass, 233 ; the Pass picketed twice a week for the passage of caravans, 53, $23 \mathrm{I}$.

Khyber Political Agency, comprising the country on both sides of the Pass, Tirāh and Mallagori, none of it administered, 23I ; now as always held or inhabited by Afrīdi Pathāns, 228.

Khyber Rifles, the garrison of the Khyber Pass, 233, their formation and subsequent (1898) augmentation and command by British officers, 232 .

Kohāt District, $167-182$; central of the Province, 167 , a raised plateau, broken by lines of moderate hills, I68, with extremes of heat and cold, drought and flood, 169; its salt beds, 168, 174; its history under Bangash and Khattak chiefs through Mughal and Durrāni supremacy, 169, 170, under the Sikhs and the British, 170, 171; expeditions against the Mirranzai tribes, 171 ; a recent decrease in the cultivated area, partly due to lightness of revenue demand and large frontier remissions, 173,176 ; increasing rail-borne trade with Tìrăh and Käbnl, 175; railway and roads, 175 ; the border military police, 177,178 ; education very backward, 178 ; bibliography, 178 .

Kohāt tahsil, I 78, I79.

Kohāt town, head-quarters of District and tahsil, and cantonment, 180, a municipality, on a branch of the NorthWestern Railway, 180.

Kohāt Pass, 53, J44, 175 ; its entrance commanded by Fort Mackeson, 162 .

Kohāt salt quarries, many in the District, 49,180 ; salt of good quality but of inferior colour, 168, 181; quantity excavated (1903-4) and average revenue, 181 ; large exports, 181 ; the considerable preventive staff necessary, 181 .

Kohāt Toi, small disappearing and reappearing affluent of the Indus, 168 .

Kulāchi, tahsīl of Dera Ismail Khān District immediately below the Sulaimān monntains, 205, a bare plain cleft by deep water-runs, utilized for irrigation, 205.

Kulächi town, head-quarters of the tahsill, an aggregation of separate hamlets, $20 S$, a municipality with a reviving trade with the Wazirs, 208.

Kunhār, river of the Kāgān valley in 
Hazära, affluent of the Jhelum, 4, 126, 142.

Kurram (or Kuram) Political Agency, a section of the Kurram valley, 236-243; the beauty and bealthiness of Upper Kurram, 238, the dreariness and heat of Lower, 238 ; its legendary and anthentic histury to the decline of the Mnghals, 238, 239; the aborigines supplanted by the Türis, 239, their raids and punishment (1854-78), 239, the fort occupied (1878) and evacuated 1880) by General Roberts, 241 ; its administration finally $(1892)$ taken over by the British at the request of the Türis, 240-243; its natural productiveness under irrigation, 240, $24 x$, its increasing crops and fruits, $24 \mathrm{r}$; its good road ( 54 miles) to the railway terminus at Thal, 181, and bridle-paths constructed in 1893,241 ; the summary settlement and the resettlement (1904), 242 , the political and religious allowances, 242 ; its generally backward education, 243; military and civil hospitals for men and women, 243.

Kurram river, rising in Afghānistān, runs through the Kurram valley proper, 237, 238, Kohăt and Bannn Districts, and falls into the Indus opposite Miānwāli, 4 , 119, in Bannu District, 182; the fertilizing value of its irrigation and silt, 183,187 .

Kurram Pass, 53, 227, twice (1878-9) forced by General Roberts, 239, 240.

Kushans, the, an early (Scythian) dynasty of North-Western India, I4, their famous kings, Kadphises I and II and Kanishka, I4, their school (Gandhāra) of art, 14, 124; supplanted by Ki-to-lo, 14 ; in Peshāwar valley, $1_{47}$.

\section{L.}

Labonrers, wages and condition of, 47 .

Lac turnery and ware, 52.

Lakki, head-quarters of the Marwat lahsil, Banno District, 194 ; displaced (1864) as capital of Marwat by a Sikh fort and town built 1844,194 .

Land, rise in value of, 46,48 . See also Rents.

Land Alienation Act, the (Punjab), extended to most of the Province, to prevent land passing to money-lenders, 43,64 , not to purely Pathān Districts of Peshāwar and Kohāt, 64.

Land revenne, native methods of assessing and collecting, $45,46,15^{8}, 191$; in the British Districts as in the Punjab, $6_{3}$; in the Agencies, $6_{3}, 6_{4}$. See also Settlement.

Landai river, formed by the junction of the Kãbnl and Swãt rivers, 4, drains a vast but dry area, 4, its size also reduced by irrigation, 4 , joins the Indns at Attock, 110, 145, its bridges of boats and ferries, 154 .

Landi Kotal, post and fort at the top of Khyber Pass, 233, taken (1897) by Afrīdis, 233.

Language, Iranian Pashtū the dominant, in its two dialects and their subdialects, $3^{1}, 3^{2}$, the distribution of their speakèrs, $3 \mathrm{I}, 32$; the dialects of the conquered strata, 32 ; a table of the numbers speaking the chief langnages, 32. See also under People in Districts.

Lawrence, George, British officer at Peshãwar, I 70, took refuge in Kohãt on outbreak of second Sikh War, 170, treacherously surrendered by Sultān to Sikhs, 1 y 1 .

Leathern-work, chiefly shooting-belts and shoes, 52.

Legislation, no Legislative Conncil in the Province, 59; the chief legislative measures affecting the Province passed since $1880,59$.

Lepers, institution for, 76 .

Levy Corps, now replaced by Militia (q.v.) save in Dīr, Swāt, and Chitrāl Agency, 73 , their duties and armament, 73.

Liquors. See Intoxicants.

Literacy, statistics of. See under People and Education in Districts.

Loans to agriculturists by Government, 42,43 , by money-lenders, 43,48 .

Lockhart, Fort, military outpost on the Sāmāna range, in Kobāt District, 18I, summer bead-quarters of general commanding military district, $18 \mathrm{r}$, the monuments here and elsewhere to the gallant Sikhs massacred at Sāragarhi in $1897,18 x$.

Lockbart, Sir W., his punitive expedition (1898) against the Afridis of the Khyber Pass, 232, 235 ; commander in frontier expedition of 189 I against Orakzais, 83 .

Lunatics, no asylum for, in the Province, 76.

\section{M.}

Mackeson, Fort, in Peshăwar District, built to command the north entrance to the Kohăt Pass, 162, dismantled ( 1887 ) save the keep, 162 .

Magistrates, 60 ; honorary, $6 \mathrm{r}$.

Mahāban ('Great Forest'), a monntain in independent territory, bordering on Peshāwar and Hazāra Districts, 108 ; its tribes, 108; wrongfully identified with the site of Aornos, taken by Alexander, 108, 223.

Mahsūds, a branch of the Wazirs, history and raids of the tribe since $1860,20-25$, $250,25 \mathrm{I}, 253,254,255$; country of the, 
$253-255$, its difficulty of penetration, 254 ; the branches of its robber tribe, 254; British attempts to organize and regulate by allowances to its maliks, 255 ; risings of and expeditions against, $20,22,25$.

Mail tongas, 55 .

Maizar, village in Northern Waziristān Agency, 245, the treachery (1897) and punishment of the Madda Khels, 22, $244,245$.

Maize, chief crop of antumn harvest, its area, localities, and return per acre of irrigated and unirrigated land, 40.

Malakand, pass from Sam Rānizai into the Swăt valley, with military post, 22I; taken (I895) by Chitrāl relief force and since occupied, $22 \mathrm{I}$, attacked (1897) by Swātis under 'Mad Mullā,' 221 ; the head-quarters of the Dir, Swät, and Chitrăl Agency, 221 ; the railway from Naushahra to Dargai at its foot, 54, 220; proposed irrigation tunnel under, $44,121$.

Malaria, its virulent and malignant forms in 'Peshāwar fever' and in Dera Ismail Khān, 30, 146; mortality from, 30 ; in Hazāra, 128 , in Kohāt, 169 , in Bannu, 184; in Dera Ismail Khān, 197; of Lower Swāt, as a cause of physical and moral inferiority, $217,220,225$.

Malik Sohrāb, founder of Hot dynasty of Upper Derajāt, 197, $20 \%$.

Maliks, heads of Pathān tribes, 24I; the failure of the British to introduce responsible government by them among the Mahsĩds, 255 .

Mānsehra, tahsīl of Hazāra District, I37, 138.

Mānsehra town, head-qnarters of tahsil, $\mathbf{1 4}^{2}$, on the main road to the Kashmir border, $\mathrm{I}_{42}$; its trade in grain and conntry produce, 142 ; near two rocks inscribed with thirteen of Asoka's edicts in Kharoshthi character, $27,143$.

Mardān, tahsīl of Peshāwar District, I59, 160.

Mardān town, head-quarters of tahsīl, cantonment, and permanent headquarters of Qneen's Own Corps of Guides, 163, fort built (1854) by Hodson, 163.

Märkhor, or wild goat, so.

Marriage, among Muhammadans a civil contract, among Hindus in theory a sacrament, 30 ; purchase of wives and sale of widows, $3 I$; divorce and other penalties of infidelity, $3 \mathrm{I}$; statistics of married, unmarried, and widowed men and women, 31 .

Marwat, tahsil, 193 ; manly tribe of Bannu District, 184 , 186 ; range, 182.

Mastũj, village, fort, and district irregu- larly subject to Chitrãl, 215 , its elevation of 7,800 feet and severe winters, 2 I 5 ; its Sanskrit rock-inscription, 2 ro, 211.

Material condition of the people, general improvement in, 47,48 , checked by the faults and vices of the population, 48 .

Mātim kotāhs, Shiah mourning-houses, 242.

Manlai, sect in Chitrāl, recognizing headship of the Agha Khān, 213.

Medical department under an Administrative Medical Officer, 76 ; civil and military meedical officers, 76 ; hospitals and dispensaries for men and women, 76 ; vaccination and inoculation, 76 , 77 ; statistics of patients, of income and its sources, of expenditnre npon hospitals and dispensaries, and of the number, success, and cost of vaccinations, 93. See also under Hospitals and Dispensaries in Districts.

Mesozoic (geological) formations, 5 .

Michni, fort (185I) in District and tahsil of Peshāwar, $16_{3}$, commands an important fersy over Kābnl river, $16_{3}$; murder of Lieutenant Boulnois ( $\left.185_{2}\right)$, of Major MacDonald (1873) by Mohmands, 163 ; since 1885 held by border military police, 163 .

Migration, immigration, and emigration, 29 , in times of scarcity, 57 .

Militia, local levies from either side of the border, employed in garrisoning trans-border outposts, 72 , their strength, armament, and stations, 72 .

Millet, spiked (bājra) and great (jowār), their area, localities, and return per irrigated and unirrigated acre, $4 \mathrm{I}$.

Mines and minerals, 49, $5 \circ$; rock-salt alone of commercial importance, 49 ; lignite in Hazara, 49; coal in the Maidān range, 49 ; iron, $49,5^{\circ}$. See also under Mines and Minerals in Districts.

Mirām Shāh, head-quarters (with garrison) of Northern Wazīistān Agency, 245.

Miränis, dynasty of, in Derajāt, 1 22, 123.

Mirānzai valleys, 168, 169 , tribes of, 169-171, punitive expedition (1855) against, 171 .

Mohmand Country, north-east of Peshāwar District, partly in British territory, under political control of Political Agent, 225-227, its unfavourable and unhealthy physical aspects, 225 ; the Mohmands and their vassal tribes, 226 ; the history of the people and of the Khāns of Lālpura, 226; their unruliness and ontrages, and the necessity of repeated punitive expeditions, $23,24,16_{3}$, $167,32 \%$. Sec also Pathān Revolt. 
Mongol invasions, 15,16 .

Monsoon, the, 11 , 1 2, 169 .

Mortality. See Death-rate.

Monntain systems, general view of, 2-4, principal ranges, 94-109. See also under Hill System in the several Districts.

Mughals, the: Bābar's first $(1505)$ raid into Indlia, 16 ; his control of the Province after his victory $(1526)$ at Pänipat, 16 ; subsequent revolts and weakening of Mughal control till the victories of Akbar's general, Mān Singh, 16, 17, the risings of the Roshānia heretics against Ảkbar, Jahāngīr, Shāh Jahān, and Aurangzeb, 17, defeats of the imperial forces, 17 , the conciliatory policy of Aurangzeb, 18 ; the decline of the Mughals, and the subjection (1738) of their governor to Nādir Shāh, 18; their inability to keep open the Khyber Pass due to the hostility of the Afridis, 228.

Muhammadan invasions and supremacy, 15 , 16, early (986) of Ghaznivids, 15 , 184 , later (1179) of Ghorids, 15 ; the Mongol invasions and overlordship, 15 , 16 ; later of Yũsufzais, 217.

Muhammadans, 92 per cent. of population, mainly Sunnis, 33; their fanatical Mullãs, 34,35 ; ample toleration of Hindu traders, 33, names, religions, and honorific titles among, 37 ; backward state of education among, and its special encouragement by stipends and; scholarships, 75, 192, 204 ; female education among, conducted in Urdū, 75 ; abstain from intoxicating liquors, not from drugs, 65 ; customary law of, $59,241,247$.

Mnles, breeding of, encouraged, 43 .

Mnllā Mastān, the 'Mad Mullā,' of Siwāt, his early history, 221 ; incited (1897) the Pathān Revolt, 22, 23, 220.

Mullā, the Adda, 227.

Mullā Powinda, a fanatic leader of the Mahsūds, 25I, 253.

Mullagori road, by which the Khyber can be turned, 228 .

Mnllās, fanatical priests of the Sunnis, 34, 35 ; their opposition to education, 157 .

Municipalities, their history, composition, revenue, and expenditure, $67,68,89$. See also under Local and Municipal Boards in Districts.

Music, Pathān, 36.

Mutiny, the (1857): disarmament of troops at Dera Ismail Khān and Kohāt, I 9, at Peshāwar, 19, I 49; the rising, pursuit by Nicholson, and ultimate destruction of rebels of Mardāu, 19, 149; the raising of new levies, 19, 20; the Province a source of strength, 20. See also under History in Districts.

\section{N.}

Nādir Shāh's defeat ( $173^{8}$ ) of the Mughal governor of Kābul, 18, 184, 218.

Names and titles, 36,37 , a son never named after his father, 37 ; importance of honorific titles, official, social, and especially religious, 37 ; a man's name a plain indication of his religion, 37.

Nathia Gali, hill station in Hazāra Dis. trict, İ 43 , with Dnngā Gali a 'notified area,' 143.

Naushahra, tahsil of Peshāwar District, 160.

Naushahra town, head-quarters of tahsil, and important cantonment, 69,163 , on the North-Western Railway and the grand trank road, 163 , the Kābul river crossed $(1903)$ by railway bridge, iron road, and bridge of boats, 164 , good roads to Mardān and Chārsadda, 164; the railway to Dargai at the foot of the Malakand Pass, 54, 220; the flood of 1858,114 .

Nawāshahr, municipality in Hazāra District, 143.

Newspaper, only one published, a weekly missionary journal, in Urdu, 75,76 .

Nicholson, General John, the Nicholson Memorial at Bannu, 194; his pursuit of the rebels of Mardañ, 149; raised new levies, 20; made first summary settlement of Bannu, I9r.

Niläbi, the boatmen of the Kābul river, 118.

North-West FrontierProvince, its position, boundaries, and area, 1 ; physical aspects, $1-12$; the history of the territory from the empire of Darius Hystaspes (c. 516 B.C.) till the formation (A.D. 1901) of the new Province, 12-26; archaeology, 26-28; population, 2837 ; agriculture, 37-43; irrigation, 4345 ; rents, wages, and prices, $45-47$; material condition of the people, 47 , 48 ; forests, 48,49 ; mines and minerals, 49,50 ; arts and manufactures, $50-52$; commerce and trade, 52-54; means of communication, $54-56$; famine, 56,57 ; administration, $57-61,67-69$; finance, $6 \mathrm{I}-67$; army, 69 ; police, 69-74; education, $74-76$; medical, 76,77 ; surveys, 77 ; bibliography, 77,78 ; genealogical, historical, and statistical tables, 79-93 ; mountains, rivers, canals, and historical areas, 94-125; accounts in detail of its five Districts, 126-209; tribal areas, \&c., $210-257$.

'Notified areas' under Act of $x 89 x, 68$.

Nummulitic (eocene) formations, 7 ; the occurrence of coal and mineral oil in connexion with them, 7 ; overlie the Kohāt salt, 7, 168 . 
O.

Occupations, $34 ; 64 \frac{1}{2}$ per cent. of population dependent on agriculture, 34. See also zunder Castes and Occupations in Districts.

Octroi, chief source of municipal income, 68.

Oghi (or Ughi), chief place in the Agror valley, Hazāra District, 143, headquarters of Hazāra border military police, 143 .

Ohind. See Und.

Oilseeds, principally til and rapeseed, $4 \mathrm{I}$; area of cultivation, $4 \mathrm{I}, 85$.

Opium, all imported, from Bengal, Mālwā, Afghānistān, and Kashmïr, 65; Punjab duty-paid admitted free, 65 ; price of, $6_{5}$, consumption, total and per head, 65 , revenue from, 67 .

Orakzai, Pathān tribe of Sāmāna range and Tírāh, 236; its chief subdivisions and their strength, 236 ; risings and punitive expeditions against, $22,23,80$, 81, 82. See also Pathān Revolt.

Orchards and gardens, cultivation of fruits in, $4^{\mathrm{I}}, 4^{2}$, area of 4,000 acres, $4 \mathrm{I}$, mostly in Peshäwar District, 42, $10_{5}$, annual exports of fruits from Peshāwar, 42 ; a daily fruit van in autumn to Calcutta, 42; of Kurram, 244.

Outposts and garrisons, military, 72 ; A Łāzai, 161, 162, Boya, 245, Chakdarra, $22 \mathrm{x}$, Malakand, 221 , Hangu, I8o, Idak, 245, Jandola, 207, 256, Fort Lockhart, 181, Sāragarhi, 181, Fort Cavagnari or Gulistān, I o9, Mirām Shāh, 245, Oghi, I 43, Pārachinār, 243, Sadda, 243 , Tānk, 209, Thal, 181, 182, W'ānā, 25.3, Drosh in Chitrāl, $21_{3}$, Drazinda, 69, 207, Jatta, 69, 207, Zam, 69; the frontier road connerting the outposts, 190 . See also Cantonments, Forts, Hill Stations, Sanitaria, Stations (military).

\section{P.}

Pakhli, its ancient name of Urasā (Hazāra), 124,128 , 129; an ancient sarkär or district of the Mughal empire, 124, roughly between the Indus and Jhelnm rivers, 124 ; in its early history associated with Kashmir, I 25 ; in Bābar's time, 125 ; its boundaries in the Aini-Akbari, 125; under the Durrānis, 125; find of Graeco-Bactrian, Kushan, and other coins, 129.

Pakhto. See Prashtū.

Panjkora, river (affluent of Swāt) and valley of $\mathrm{Dir}, 215,216$.

Pārachinàr, head-quarters of the Kurram Agency and militia, 243, its temperate

sw.F.r. climate and natural fertility under irrigation, 243 .

Pashtū, the dominant speech, 31 ; its main dialects-hard or north-eastern Pakhto, soft or south-western Pashto, 3I, their asserted correspondence respectively with oligarchic and democratic organization, $3 \mathbf{1}$; its classical and literary dialect of the Y'üsufzai, $3 \mathbf{I}, \mathbf{3}^{2}$.

Passes, British control of, by Treaty of Gandamak, 20, 25, 232, by Durand agreement, 25,26 ; snrveys of, 77 ; as trade routes, 27,53 ; defence of, in Chitrāl by scouts, 72,73 ; over the Himãlayas to Tibet, 106, 107; from Peshāwar into Swāt, 144, Lawarai to Chitrāl, 213, Mohmand, 21, 225, 226, Ambela, 224, 225 , the Peiwar Kotal, $2,55,240$, the Shutargardan, 21, 55, 239, 240, Kurram, 227, 239, 240, Kolıāt to Baunu, 53, 144, 175, Gomal, 253, 254, Malakand, 53, 22 I, Khyber, 227-232, of the Black Mountain, 107.

Pathān Revolt, the (1897), its religious and other causes, and spread from Tochi, through Swāt, the Mohmands, and Tīrāh, 23, 24; its suppression ( 1898$)$ and punishment, 24,82 .

Pathāns (Pakhtāna), the dominant class, speaking the dominant language, 32 ; no longer race but the status of a sharer in the tribal estate and conncils denoted by the term, 32 ; their distribution, number, and often mixed origin, 32,33 ; genealogical table of, 79 ; their toleration of Hindus, 33, abstemiousness, 35, extravagant hospitality, 35,36 , their love of field sports, robbery, and music, $3^{6}$, their club in the guest-house, $3^{6}$; their natural and acquired laziness as cullivators, 39 ; their extravagance, improvidence, litigation, and crime, 48 ; their ancient systems of tennre and of the periodical redistribution of land, 62,63 ; their claim of ' eye for eye,' 247 ; their blood-fends, $247,25^{2}$.

Patwāaris, or village accountants, $5^{8}$.

Peshäwar District, 143-167; a huge basin, surrounded by hills save to the east, and drained by the Kābul river, 143 , 144 ; the independent tribes of the hills, 143,144; from May to October dusty, hot, and oppressive, with deadly malaria, $1_{4}^{6}$, large game scanty, $1_{4} 6$; its early history as the meeting-point of Greek and Bnddhist culture, 146,147 , under Mruhammadan, Mongol, and Mugbal supremacies, $147^{-1} 49$, the immigration of Afghāns in the fifteenth century, 148 , nnder the Durränis and the Sikhs, 149 , uncler the British ( 1848 ) and during the Mutiny, I 49; its great fertility under irrigation (40 per cent.), I 51 , 
152 ; its cotton, woollen, and copper industries, 153 ; its internal trade and more important through trade from Kābul and Bokhāra, 153; jts railways, roads, and rivers, 154 ; its heavy criminal work, 155; the land settlements and revenue, 155,156 , frontier remissions, 156 ; police, civil and border military, 156,157 ; standard of literacy (4 per cent.) lower now than in 1891,157 ; medical, 157 ; bibliography, 157 .

Peshāwar tahsìl, consists of a low-lying basin of the Kābul river, and of uplands rising to Afridi hills, $15^{8}$; intersected by Kābul River Canal, 158 ; its headquarters the city and cantonment of Peshāwar, $15^{8}$.

Peshāwar City, capital of the Province, head-quarters of the District and tahsil, 164-166; its historical importance and religious associations, 164 ; its connexions by rail with Calcntta and Bombay, and with Jamrūd fort ( $10 \frac{1}{2}$ miles) near the Khyber Pass, 164, by road (190 miles) with Kābul, I64; its population of nearly 100,000 , over twothirds Muhanımadans, 164; its large cantonment, the head-quarters of the Peshāwar military division of the Northern Command, and its finance, $164,165,166$; the garrison pack of hounds, 146 ; the modern town with mud (being replaced by brick) walls and sixteen gates, $16_{5}$; water-works and good sanitation, 165; handsome mosques, and the Gor Khattri, once Buddhist and Hindu, now the tahsili, 165 ; the strongly fortified and armed Bāla Hisãr outside the walls, 165 ; the public and private gardens of the suburbs, 165 ; finance of the municipality, 166; public institutions, 166; trade, $\mathrm{s} 66$.

Petroleum springs in Kohāt District, 7, 174.

Pinjra, lattice-work made at Peshāwar, 52.

Plague, epidemic, its appearance (1906) in parts, 30 .

Police, border military, originally formed on the silladari system, to guard agaiust border raids, $7 \mathrm{I}$, now a regular force of horse and foot, on garrison and patrol dnty, 72, I57; its strength, 72 . See also under Police and Jails in Districts.

Police, civil, its administration under an Inspector-General, 69, 70, its history since annexation, 70 ; its present position, strength, armament, and training, 70 ; proportion of, to area and population, 7o; rural, municipal, cantonment, ferry, and railway police, 70,71 ; cognizable crime, statistics of, $\boldsymbol{r} \mathbf{~}$; statistics of and expenditure on, $9 I$. See also under Police and Jails in Dis: tricts.

Political Agencies, five, each under a Political Agent, 59 .

Pollock, General, the march of his army $(1842)$ back to India through the Khyber Pass, 230, the various fortunes of the three divisions, 230.

Pomegranàtes, of Peshăwar, 42.

Population, total of, nearly four millions, 28; average density, 152 per square mile, highest $(152)$ in valley of Peshāwar, lowest (42) in Kurram Agency, 28; its distribution between towns and rural areas, 28 ; the tendency, due to the scnse of security, to found new homesteads, 28; growth of, 30 per cent. since $188 \mathrm{I}$, nearly 10 per cent. between 1891 and 1901, 29; statistics of age, 29; statistical table of distribution, \&c., of population, 84. See also under People in Districts.

Post office, two postal divisions, $5^{6}$; Province included with Kashmir in a single telegraph division, 56 .

Post-Tertiary and recent (geological) formations, $7,8$.

Pottery, glazed and unglazed for native use, made at Peshāwar, 5 I, unglazed in Hazāra and Bannu, 52.

Powindas, nomad merchants, armed conductors of. camel caravans, pass through withont breaking bulk, 53,202 ; the articles of their trade, 202; of Gomal Pass, 208, 253.

Prāng, town in Peshāwar District, pract1cally a part of Chārsadda (q.v.), 166, 167.

Prices, of agricultural staples and salt, 47,48 , their rise compared with the greater rise in wages, 47 ; of opinm, 65.

Public works (save canals and railways), in charge of Commanding Royal Engineer of the Province, 68.

Pulses, other than gram, their area of cultivation, 41 ; average prices of, $4^{8}$.

Punjab Frontier Force, formerly responsible for the peace of the border, 19,69 ; its transfer (1886), with enlarged sphere of service, to control of Commander-inChief, 69; the present cavalry and infantry regiments of the force, 69 .

Pushkalāvati (Peukelaus or Peukelaotis of Greek historians), ancient capital of Gandhāra, I 24 ; identified by Cunningham with Chārsadda and Prāng (q. v.), 13,161 . 
$\mathrm{R}$.

Railways, 188 miles of, 55 ; the Province traversed by the North-Western Railway, crossing the Indus at Attock to Peshāwar, $5+$; its three points of communication: from Peshâwar a broadgauge extension ( 12 miles) to Fort Jamrūd at the mouth of the Khyber, 54, I54; from Naushahra cantonment a narrow-gauge branch to Dargai at the foot of the Malakand Pass, 54, 220; at Khushālgarb, 53 miles below Attock, the Māri-Attock branch and a bridge of boats (soon to be replaced by a railway bridge) connecting main line indirectly with narrow-gauge to Kohät and Thal, 54, 175 ; indirect communication of Dera Ismail Kbān by a bridge of boats in the cold season with Daryā Kbān, on the Sind-Sāgar branch of the North-Western Railway, 54, 55; railway police, 7r. See also wnder Means of Communication in Districts.

Rainfall, II ; everywhere capricious, but on an average sufficient, $38,56,57 ; 7^{2}$ per cent. of cultivated area dependent on, 43: lightest (9 inches) in Dera Ismail Khãn District, heaviest (45 inches) in Hazāra District, 11,57 ; statistical table of, 83 ; its variations and compensations in different tracts, 56,57 . See also under Rainfall in Districts.

Rapeseed, 41.

Registration, of documents, chiefly by officials, $6 \mathbf{r}$.

Religion, $9^{2}$ per cent. Muhammadans, mainly Sunnis, 33; the gloomy fanaticism, compatible with low morality, preached by the Sunni Mulläs or priests, 34,35 ; religious titles, 37 ; the numerous shrines of pilgrimage with fairs and cures, 34; Christians, 0.25 per cent., 34, the Anglican and Roman Catholic ecclesiastical administration, 34 ; the infuence of fanatics of old, under the Mughals, 17, recently, 20, 22, 23, 218, $219,224,251$. See also under People in Districts, Akhund, Mullās, Roshānias, Saiyids.

Rents, as surplus orer for owner of land, uncler native rule, none, 45 ; now the margin left by milder British assessments and often thrce times their value, $45,4^{6} ;$ paid in cash and kind, $4^{6}$; their regulation in cases with rights of occupancy, $4^{6}$; the rise in, $4^{6}, 4^{8}$.

Revenue courts, 6 r.

Rice, little cultivated, 4 r, 85 ; its area, localities, and return per irrigated acre, 4 I.

Rivers, 4, 56, 97, 109-120, all part of the Indus system except the Kunhär of
Hazāra, 4, 126; trade on and convcyance over, 56. See also under River System in the several Districts.

Roads, supplementing railway system, $\mathbf{5 5}$, metalled : the grand trunk to Peshäwar through the Khyber to Landi Kotal, 55 ; metalled road from Peshāwar through the Province to Ismail Dera Khān, 55; from Khushālgarh to Kohāt and Thal, 55 ; from Thal up the Kurram valley to Pārachinār, whence a trade route over Peiwar and Shutargardan Passes to Kābul, 55; to Datta Khel and Murtazā, 55 ; the road to Hazāra and thence to Kashmirr, starting from Hassan Abdāl Station on the North-Western Railway, 55; other roads, 55; their maintenance, 55 ; the frontier road or mule track connecting the outposts, 190 . See also under Means of Communication in Districts.

Roberts (Lord), forced pass and occnpied (1878) Kurram fort; 240 , crossed the Shutargardan Pass, 240.

Roshānias, heretics and rebels (1 586-1676) against the Mughal empire, 17, 218 , their frequent defeats of the imperial forces, 17 , their leader Jalăla, 17 , their stronghold in Tìrāh, I 7 ; in the Khyber country, 228, repulsed the Mughals (1620) in Tīrāh, 235 .

Rotation of crops, 38, 39 .

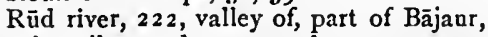
its tribes and communal party government, 222.

\section{S.}

Sadda, post in the Kurram Agency, 243 . Safed Koh ('white mountain') range, thc watershed between the valley of Jalälābäd and the Kurram, 237, its line, spurs, and peaks, 3, 237, its branches from Mittugarh enclosing the valleys of Tīāh, 233, 234, the Khyber Pass on its last spurs, 227.

Saiyids, reverenced by the Shiahs as descendants of Alī, 34; Saiyid Ahmād of Bareilly, his colony (1825) of fanatics in Swāt, 218,224 , defeated and slain by the Sikhs, 224 ; his successor Saiyid Akbar Shāh, his fort at Mālka, 224, campaigns of $1853,185^{8}$ against, 20 , 224 , of Ambela (1893), $21,225$.

Salt, industry of, 49,64 ; the Kohãt quarries, 180,181 ; its purity and colour, grey to black, compared with the red or pink of the Salt Range, 168; its geology, 7,168 and $n$.

Salt, revenue from, 64,65 ; duties on, 64 , preventive line (1849) withdrawn (1896), export to cis-Indus still prohibited, 64 ; table of large exports beyond 
the Province, of small imports, and of gross revenue, $6_{5}$, consumption per head, 65 ; the preventive establishment, I 8 I.

Sāmāna Range, separating the Mĩrānzai and Khānki valleys, 108 , its line of forts, 100.

Sāmäna Rifles, with heač-quarters at Hangu, 1 So.

Sandeman, Sir R., opened (I889) Gomal Pass, 250.

Sanitaria, in Hazāra District, Dungā Gali, I41, 143; Thandiāni, 143; in I'eshāwar, Cherāt, I 61,162 ; between Bannu and Dera Ismail K'hãn, Sheiklı Budīn, 208, 209.

Sanitation, municipal expenditure on, 89 ; good of Peshāwar, 165, good natural of Kohāt cautonment, i80, bad of Dera Ismail K̉hān, 207.

Sappers and miners, stations of, 69 .

Säragarhi, village on the crest of Sāmāna range, Kohāt District, lield by the ]3ābi Khel, I81; outpost built (1S91), ovcrwhelmed (1897) by Orakzais and the small Sikh garrison massacred, 181.

Sarwar Khān, progressive Nawāb of Tānk, 206, his submission to the Sikhs, 206, his grandson, protected by Edwardes, made and unmade chief by the British, 206, died $1882,206$.

Scenery, general of Province, I, 2; of Him. alayas, 96 , of the Indus, $109,110,112$, of Hazàra, 126, 127, of Agror, 139, of Peshāwar, 144, of Dera Ismail Khān, 195, I96, of the Mohmand conntry, $\mathbf{2 2 5}$, of the Khyber, 227, 228, of Kurram Agency, 238, of Soushern Waziristān, $\mathbf{2 4 8}, \mathbf{2 4 9}$, of the country of the Mahsüds, 254 .

Sclools, primary and secondary, 74, 75, Urdū and Hindī, \&c., schools, 75, Anglovernacular, 74, 75. See also under acalion in Districts.

Self-government, local : by municipalities of appointed and $e x$-officio members, their history and present position, $6 \%$, 68 ; revenue and expenditure, 68,89 ; by District boards, composed of nominated members, their sphere, income, and expenditure, 68, 90. See also under Local and Municipal Boards in Districts.

Settlenient, or asscssment of land revenue, $6_{3}$, in the Districts as in the Punjab, but, often for political reasons, lighter, $6_{3}$; frontier remissions, 156,173 ; the demand in different Districts between $5^{2}$ and 75 per cent. of balf 'net assets,' 63 , the term, generally twenty years, 63 ; in the Agencies, 63, 64, in Kurram, 241, 242; settlement maps, 77. See also under Land Revenue in Districts.
Sex, statistics of, 30 ; the decreasing ratio $(8,34)$ of females to $(1,000)$ males, 30 .

Shabkadar, fort in P'eshâwar District, con nected by a good road of 17 miles with Peshāwar, 167; since 1885 held by border military police, 167 , defeat of raiding Mohmands ( 1897 ), 16\%.

Shāhbāzgarhi in Peshāwar, Asoka's Kharoshthī rock-inscriptions at, 27.

Shecp (and goats), thin-tailed and fattailed, 43, a large demand for mntion in the cantonments, 43. See also under Cattle, Ponies, and Steep in Districts.

Shcikh Budin, hill (4,5 16 feet) station and sanitarium (1\$60), military and civil, between Bannu and Dera Ismail Khān Districts, 208, 209; bare, hot, and short of water, 209.

Sher Afzal, pretender and disturber of Chitrāl, finally deported to India, $212,213$.

Shiahs, their very small nnmber, 33 , their reverence for Saiyids, the descendauts of $\mathrm{Ali}, 34,130$; the endowment by the British of their mâtin kotāhs or 'mourn. ing-houses 'in W azīristān, 242.

Shirāni Country, a poor hilly tract on the western border of Dera Ismail Khān District, 256 , divided into a lowland under political control (1899) of North-Westcrn Frontier Province, and a highland under that of Baluchistān, 256 ; the intense democracy and robber raiding habits of the tribe, 256,257 ; the Rritish agreement with (1899), 257 ; the murder (1902) of the Extra Assistant Commissioner, and the escape into Afghānistān of the murclerer and his gang of malcontents, 2.57 .

Sikhs, the : their invasions and conquests from 1818 , their great victories over the $A$ fghāns ( 1823 and 1832 ), is, 149 ; their raids and exactions of tributc (1823-34), I8, 149; the change of Sikh policy, after the death of Ranjit Singh, I 8 ; the rnle of General Avitabile $(1838-42)$, 18, 149; the outbreak (1848) of the second War at Multān, 185 , the march thither of Edwardes with new levies, I 85 ; the invasion of Bannu repelled by Reynell Taylor, 185 ; their heroism (1897) at Sãragarhi, 181; the most advanced community in Bannu, 192, in Dera Ismail Khān, 204; their rule (and exactions) in Hazāra, 129,135 ; in Peshāwar, 149; the inability of Kanjīt Singh to levy revenue in Kohāt and Bannu, 170,184 ; in Dera Ismail Khản, 198. Silk-spinning and weaving, important in: dustries at Peshāwar and Kohät, 50, 153, 175 .

Silladäri system of border military police, adoptcd, abused, abolished, 71 . 
Small-pox, very common among Pathāns, 76 , its small mortality, 30 ; hereditary art of inoculation for, 76,77 ; vaccination against, 76,77 .

Soils, their character and variety, 37,38 , their fertility not so important as facilities for their irrigation, 38,39 . See also under Agricnlture in Districts.

Stallions, for improvement of breed of horses and donkeys, maintained by Veterinary department, $\mathbf{1 3 2}, \mathbf{1 5 2}$.

Stamps, judicial and non-judicial, revenue from, 67 .

Stations, military, a list of, 69. See also Cantonments, Forts, Hill Stations, Outposts and garrisons.

Stein, Dr., on the mistaken identification of Aornos with Mahāban, 108, 223; on the derivation of Hazāra, I 28 ; his visit (1898) to Buner and identification of several sites of historical or religions interest, $27,223,224$.

Stone, a common disease, 30 .

Stüpas. See Buddhism.

Surveys, conducted independently by local Revenue establishment and by Survey department, 77 ; its progress in settled and unsettled territory, 77 ; surveys of the passes, 77 .

Swābi, tahsīl of Peshāwar District, formerly known as Utmān Bulak, 160.

Swāt, 23, 24, 216-221; tract in the Dīr, Swāt, and Chitrāl Agency, the fertile valleys drained by the Swāt river, 216 , the forests of the upper tract or Kohistān, 216 , the malaria of the lower tract, its moral and physical effects, $217 ;$ its tribes, clans, languages, and religion, 220, 22I ; for its history, religious and other wars, pnnitive expeditions, \&c., against, see under Dīr, Swāt, Bājaur, and Utmān Khel, their history. See also Pathān Revolt.

Swàt river, formed by junction of the Gabral and Ushu, 116 , its course of 400 miles to its junction with the Kābul river, 116 ; fordable in midwinter, 116 ; its canal, 120 ; its three bridges of boats and twelve ferries, $154,16 \mathrm{r}$.

Swāt River Canal, a perennial irrigation work, supplying I55,000 acres, I 20; its natural weir, channels, aqueducts (167), and district of supply, 120; its proposed extension, 121 ; its capital cost, and unexpected profits, 121 .

\section{T.}

Tahsils, tahsildärs, and naib-tahsildairs, 58.

Takht-i-Sulaimān ('Solomon's throne '), a shrine (ziārat) on the Sulaimān range (1 I,295 feet), 3, 257; its legend, 257 .
Tanāwal (or Tunāwal), a mountainous tract in Hazāra District and semiindependent estate, $13^{8}$; its history under the Tanāwalis, a tribe of Mughal descent, $13^{8}$, its present chiefs with large powers, the Nawāb of Amb, K.C.S.I.; and the Khān of Phulra, I $38,139$.

Tanāwals, arenaceous and calcareous rocks in Hazāra, partly infra-Trias, 4,5 .

Tangi, town in Peshāwar District, near the Jhindi aqueduct of the Swāt River Canal, i67.

Tänk, snbdivision and tahsīl of Ismail Dera Khän District, 205; a dry plain intersected by ravines and hills, assidnously and successfully cnltivated, 207 ; once a semi-independent State under a Nawāb of the Daulat Khel, 205; the progressive rule of Sarwar Khān, 206; its submission to the Sikhs and their exactions, 206; the restitution of the ruling family (1849) in Shāh Nawāz Khān and his deprivation, 206.

Tānk town, head-quarters of subdivision and tahsil, 209; its mnd wall and ruined fort, 209, a 'notified area,' 209, its trade with Waziristān, 209; the place of the death (1870) of Sir Henry Durand, Lieutenant-Governor of the Punjab, 209.

Tappa, a block or circle of villages, the old administrative and fiscal unit in Bannn, 158, 191, the method of collecting revenue from, I9I.

Tarkhāns, or carpenters, a numerous artisan class, rising to be a professional class of trained engineers, 33. See also under Castes and Occupations in District.

Taylor, Lieutenant Reynell, Edwardes's successor in Bannu District, 185, kept invaders at bay during second Sikh War, 185 .

Temperature, $12, \operatorname{maximum} 122^{\circ}$ at Dera Ismail Khān, minimum minus $13^{\circ}$ at Wānā in Jannary, 1905, 12; statistical table of, 83. See also under Climate and Temperature in Districts.

Tenants (agi icritural), paying rent, not a very large class, $39,45,46$; the ratio of rents to assessments and produce, 46 ; the protection of tenants with rights of occupancy, 46 , and of all in respect of ejectment and compensation for im: provements, 46 .

Tenures of land, native or Pathān, originally tribal, 62 ; the divisions and subdivisions of the holding of a tribe into final scattered shares, each of an individual, 62 ; the periodical (from every five to twenty years) redistribution (vesh) of the land by lot or otherwise, 62,63 ; the ves/ now becoming obsoletc, save in the unadministered territories, 63 . 
Tenures of land, present, generally as in the Punjab, 63 ; in IHazăra, 131 ; by peasant proprietors in l'eshāwar, 151 , and in Bannu, 188 ; in Dera lsmail Khān, 200.

Teri tahsil, forming half of Kohāt District, 1 79; its distinct fiscal history, 177 ; the loyalty of the Khān during the Afghān War, 171,177 , his reward, 179 ; its inhabitants, the Khattaks, 179.

Tertiary (geological) rocks, 5-7.

Thal, subdivision of Kohät District, with head-quarters at Hangu, $179,180$.

Thal village, military out post in Kohät District, on a branch of North-Western Railway, 181, new police post and resthonse (1905), I 82 ; dépôt for through trade by Kurram valley, 181, $24^{1}$.

Thandiāni, small hill sanitarium of Abbottābād cantonment, I 43 .

$T i l$, oilseed, 4 I.

Tillage of soil, primitive and half-hearted, 39.

Timmurr, his devastation $(1398)$ of the Punjab, 16.

Tîrāh, a mountainous tract of unadministered territory, $233-236,23,24$; its inhabiting tribes, 233 , rivers, valleys, and branches of the Safed Koh, 233, 234; high elevation and generally healthy climate, 234; history of resistance to Mughal empire and independence since its decay, 235 ; the punitive expedition (1898) under Lockluart, 235, 236; increasing railborne trade with, 175. See also Pathān Revolt.

Titles, official, social, and religious, of Muhammadans and Hindus, 37 .

Tobacco, area of cultivation, 85 ; its universal use opposed by Mullās, 35 .

Tochi (or Gambila) river, 100-150 miles long, rising in Afghānistān, falls into Kurram, II9; much formerly, less lately, used for irrigation, 119 ; in Bannu District, 182,187 .

Tochi valley, 246, 247; the treachery and rising in the beginning of the Pathān Revolt, 22, 3.3.

Tongas (wheeled vehicles), 55 .

Towns, one (Peshāwar) large, five with more than 10,000 inhabitants, fifteen smaller, 28 ; total population of $(269,905), 28,84$.

Trade and Commerce : its importance due to the Province lying across great tradc-routes, 52 ; routes to and items and valnes of trade with Buner and Bājaur (including countries east of the Hindu Kush), Tīrāh, Afghānistān, Central Asia (through Kābul), Kashmir, and other Provinces and
States of India, 52-54; 153 ; statistical tables of trade of Province, 86, 87; restrictions on trade with Bokhāra and Afghãnistān, 53; main trade through rather than in or with the Province, 153; of Peshāwar, 153, 166, of Dera Ismail Khān, 202, 20\%, 208. See also under Trade in Districts.

Trade castes and classes, the Arnras and the Khattris, 33, 130, 150 . See also under Castes and Occupations in Districts.

Trade centres of Peshāwar, 153, Kohāt, 175, Bannu, 189, Dera Ismail Khān, 202.

Treasure, excess of exported over imported, 54,87 .

Trees, principal of forests, $49, \mathrm{I} 33$.

Trias (geological) formation, the beginning of a generally continuous zoological sequence, 6 .

Tribe, the, the social unit of the Pathinns, 67 ; its periodical redistribution of propeity and rights, $62,63,67$; the introduction of the village community and responsible headman by the British, 67 ; the tribal customs of the Wazirs, 252 ; the failure to make the maliks responsible representatives of the Mahsūds, 255.

Tribes, of the Pathāns, 32, 33, 79; of the Himālayas, 104,105 ; of Black Mountain, 10\%, 108; of Mahāban, 108 ; of the Peshawwar hills, 143, 144; of the Political Agencies, $210-257$; statistical table of tribes against whom expeditions bave been undertaken (1849-92), 80-82; genealogical table of Pathān, 79.

Tunnels, irrigation, 119 ; proposed under Malakand, 44, 121 .

Türis, the dominant tribe of the Kurram valley, 239, 240; the Tinrizina or customary law, $24 \mathrm{I}$; their administration taken over (1892), at their own request, by the British, 240 .

Typhus fever, frequent recent epidemics of, 30 ; former ravages of, in jails, 74 .

\section{U.}

Udyāna, ancient kingdoin of (Swāt), 26 ; knowledge of, derived mainly from coins and inscriptions, 27.

Ughi. See Oghi.

Umra Khān of Jandol, his conquest $(1882-90)$ of Dir, 219 , his interference with Chiträl (1895), 212, his final rupture with the British Government, open war, and siege of Chitrăl, 212 , his defeat and fight (1896) to Käbul, 219. 
Und (Hind, Ohind, or Waihind), now a village, on the west bank of the Indus, 15 miles above Attock, 125 , once a rich and great city, the capital of the rulers of the Kābul valley and Gandhāra before the Muhammadan invasion, 124 125; the place of the victory of Mahmund of Ghazni, which opened his way to the Punjab, I 25.

Uriāl, or wild sheep, Io.

Utmān Khel, mountainous tract on both banks of the Swāt in Dìr, Swāt, and Chitrāl Agency, 222 ; inhabited by quarrelsome clans of Utmān Khel Afghāns, 222 ; punitive expeditions against, 24 , 82,222 .

\section{V.}

Vaccination, organization of, 76 , popular but interfered with by old hereditary habit of inoculation, 77 ; successfnl transformation of inoculators into vaccinators, 77; foll statistics of, 93 . See also under Vaccination in Districts.

Vesh (khulla vesh, 'mouth division'), the Pathān practice (now obsolescent) of periodical redistribution of the lands, water-rights, and houses of the tribe, $62,63,67,188$; its bad effect npon cultivation, 39,216 .

Veterinary department, its stallions for the improvement of horses and donkeys, in Hazāra, 132, in Peshāwar, 152.

Village community, the, not indigenous, 67 , introduced by British with responsible headman, 67 .

Villages (and rural areas), population of $(1,855,575), 28$, number of $(3,348), 28$, 84 ; hitherto and still, beyond administrative border, fortified against one another and external enemies, 28,29 ; the village gnest- and club-house, 35,36 ; watchmen, $70,71,9 \mathrm{I}$, accountant, $5^{8}$, headmen, 58, 67 .

Vital statistics, defective data of, 29 , method of collection, 29, principal statistics, 30 .

\section{W.}

Wages (and income), of landless labourers, 47 , of cultivating tenants, 47 , of peasant proprietors, 47 , of skilled labour, 47 , of clerks, 47 ; have risen more than prices, 47 .

Wanā, a wide open valley, containing the Wanna post, the head-quarters of the Sonthern Waziristān Agency, 253; its well-caltivated and irrigated riverain of the Toi, 253.
Wānā, post and head-quarters of the Southern Wazīristān Agency, 253 , scene of Mahsūd attack (1894) on British delimitation escort, 253 .

Water-rights, their valne and intricacy, 45,189 , water rates or rent, 46 , et passim under Land Revenue; water-supply to Peshāwar, $118,16_{5}$; expenditure of Province on, 89 .

Wazirs, the tribe of, their two great sections, the Darwesh Khel and the Mahsüds, 251 ; their subdivision into numerous clans, 1 87, 244, 254; their language and tribal customs, $251,252$.

Wazìistān, Northern, Political Agency, with head-quarters at Miram Shāh, 243-248; its boundaries, hills, and four large and fertile valleys, 243,244 ; none of it adıninistered save the Tochi or Danr Valley, 245 ; its inhabitants Darwesh Khel Wazirs, the least tractable of Pathān tribes, 244 ; raids and punitive expeditions, 244,245 ; the militia and its posts, 245 .

Waziristān, Southern, Political Agency, with head-quarters at Wānā, constituted in $1896,24^{8-253}$; its boundaries, 248 ; the Wazirs, its dominant tribe, $248,25 \mathrm{I}$, 252 ; its peaks, plateaux, river, and Gomal Pass, $24 \mathrm{~S}-250$, flora and considerable fauna, 249 , its unwholesome lower valleys, healthy higher, 249,250 ; the history of the Mahsūd Wazirs (1860-1900), a series of raids, punitive expeditions, and broken agreements, $20-25,250,25 \mathrm{I}, 254,255$; its insufficient agriculture, 252 , inconsiderable iron and other industries and trade, 252,253; its militia, 25 I.

Weather, the, at different seasons, 11,12 ; at Peshāwar, 146. See also under Climate and Temperature in Districts.

Wells, irrigate less than one per cent. of cultivated area, 43,85 , their places of occurrence, 44, their construction and working, 132 .

Wheat, chief crop of spring harvest, its area, 40 , one-third irrigated, 40 , its yield per irrigated and unirrigated acre, 40 ; wheaten bread the rule in towns, 34; average price of, 48 . See also under Agriculture in Districts.

Widows, no prejudice against remarriage of, $3 \mathbf{I}$; their nnmber, rights, and liability to be sold, 31 .

Women, low position of, 30 ; purchase of wives, 31 ; rights of widows and unmarried daughters, 31 ; divorce, 31 ; dress and coiffure of, 35 ; relnctance to register births of danghters, 29; female education, Muhammadan and Hindu, 75 , by lady missionaries, $15 \mathrm{I}$; hospitals and dispensaries for, 76 ; the 
sale of Chitrāl girls for Afghān harems, 214.

Woodwork : boat-building and carpentry, 52; pinjra lattice-work, jointed not glued, of Peshāwar, 52; lac turnery and lac-ware, 52.

Woollen industries, 50 .

Y.

Y'ūsufzai, a subdivision of Peshāivar District, comprising the tahsils of Swābi and Mardān, I 59; properly the whole territory beld by the Yusufzai tribe of
Pathāns, 158 ; their clans, 220 ; their speech, the classical and literary dialect of Pashtü, 31, 32, 220. See also Dir, Swăt, Bäjaur, and Utmăn Khel.

Z.

Zakka Khel or clan of Afridis in the Bāzār valley, 236; the most active thieves on the frontier, 236; punitive expeditions against, $81,82,236$.

Zanāna Mission at Peshāwar, 151, 157; at Dera Ismail Klıān, 200. 






$\sqrt{2}$

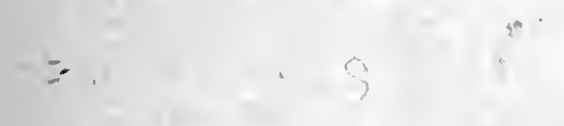

$\because \div$ 



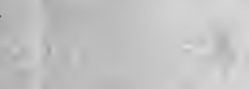

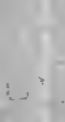



DS

$485^{\circ}$

N7I5
Imperial Gazelveer of India North-Wes $u$ Frontier Province
PLEASE DO NOT REMOVE CARDS OR SLIPS FROM THIS POCKET

UNIVERSITY OF TORONTO LIBRARY 
